INTER NATIONAL MONETARY FUND

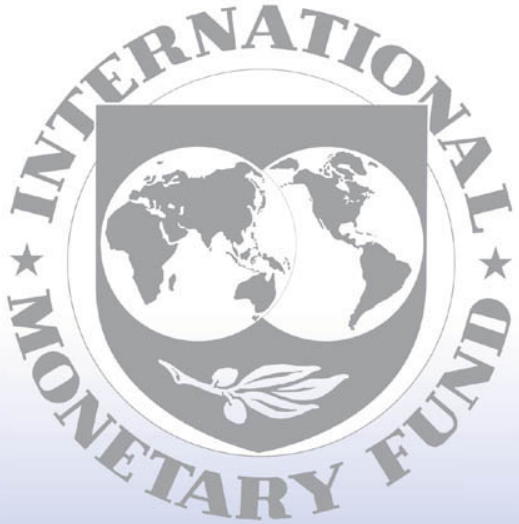

Staff

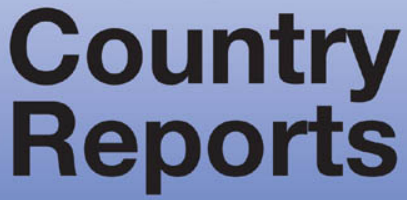




\section{Bolivia: Report on the Observance of Standards and Codes- Data Module, Response by the Authorities, and Detailed Assessment Using the Data Quality Assessment Framework (DQAF)}

This Report on the Observance of Standards and Codes on Data Module for Bolivia was prepared by a staff team of the International Monetary Fund as background documentation for the periodic consultation with the member country. It is based on the information available at the time it was completed on August 2, 2007. The views expressed in this document are those of the staff team and do not necessarily reflect the views of the government of Bolivia or the Executive Board of the IMF.

The Response by the Authorities to this report, and the Detailed Assessments Using the Data Quality Assessment Framework (DQAF) are also included.

The policy of publication of staff reports and other documents by the IMF allows for the deletion of market-sensitive information.

To assist the IMF in evaluating the publication policy, reader comments are invited and may be sent by e-mail to publicationpolicy@imf.org.

Copies of this report are available to the public from

International Monetary Fund $\bullet$ Publication Services

700 19th Street, N.W. • Washington, D.C. 20431

Telephone: (202) 6237430 • Telefax: (202) 6237201

E-mail: publications@imf.org • Internet: http://www.imf.org

Price: $\$ 18.00$ a copy

\section{International Monetary Fund Washington, D.C.}


This page intentionally left blank 
INTERNATIONAL MONETARY FUND

BOLIVIA

\section{Report on the Observance of Standards and Codes (ROSC)—Data Module}

Prepared by the Statistics Department

Approved by Robert W. Edwards and Anoop Singh

August 2, 2007

The Report on the Observance of Standards and Codes (ROSC) data module provides an assessment of Bolivia's macroeconomic statistics against the recommendations of the General Data Dissemination System (GDDS) complemented by an assessment of data quality based on the IMF's Data Quality Assessment Framework, July 2003 (DQAF). The DQAF lays out internationally accepted practices in statistics, ranging from good governance in data producing agencies to practices specific to datasets.

The datasets covered in this report are (1) national accounts, and consumer and producer price indices, compiled by the National Statistics Institute (NSI); government finance statistics, compiled by the Ministry of Finance (MOF); and monetary and balance of payments statistics, compiled by the Central Bank of Bolivia (CBB). The mission also assessed the Prerequisites of quality and Assurances of integrity of the Superintendency of Banks and Financial Entities (SBFE), which provides source data for monetary and balance of payments statistics.

The datasets to which this report pertains can be accessed in print and on the Internet:

- $\quad$ CBB website (http://www.bcb.gov.bo)

- MOF website (http://www.hacienda.gov.bo)

- NSI website (http://www.ine.gov.bo)

- SBFE website (http://www.sbef.gov.bo)

This report is based on information provided prior to and during a staff mission from January 24-February 7, 2007 and publicly available information. The mission team was headed by Edgar Ayales, and also comprised José María Cartas, Eduardo Valdivia-Velarde, Rita Mesías, and Ricardo Davico (all STA), and Pablo Mandler and Gilda Salvato (external consultants). 
Contents

Page

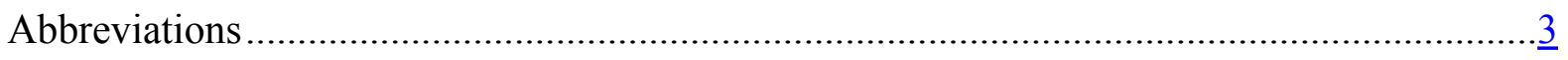

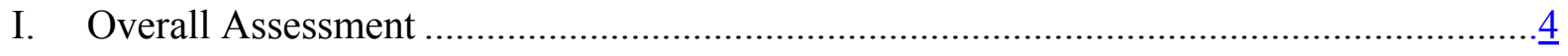

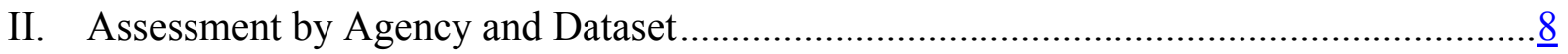

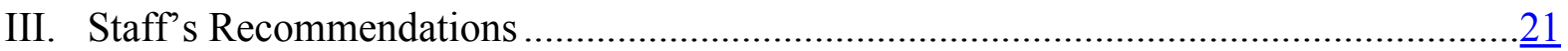

Text Tables

1. Data Quality Assessment Framework July 2003 — Summary Results..........................10

2a. Assessment of Data Quality-Dimensions 0 and $1-$ National Statistical Institute .........11

2b. Assessment of Data Quality-Dimensions 0 and 1-Ministry of Finance .....................12

2c. Assessment of Data Quality_Dimensions 0 and 1-Central Bank of Bolivia...............13

2d. Assessment of Data Quality-Dimensions 0 and 1-Superintendency of Banks and Financial Entities ........................................................................................ 14

3a. Assessment of Data Quality-Dimensions 2 to 5-National Accounts ......................... $\frac{15}{16}$

3b. Assessment of Data Quality-Dimensions 2 to 5-Consumer Price Index................... $\frac{16}{17}$

3c. Assessment of Data Quality-Dimensions 2 to 5-Producer Price Index ......................17

3d. Assessment of Data Quality-Dimensions 2 to 5 - Government Finance Statistics ........18

3e. Assessment of Data Quality-Dimensions 2 to 5 -Monetary Statistics........................ $\underline{19}$

3f. Assessment of Data Quality_Dimensions 2 to 5-Balance of Payments Statistics ........20

Appendix

I. Practices Compared to the GDDS Coverage, Periodicity, and Timeliness of Data .........24 


\section{Abbreviations}

1968 SNA

1993 SNA

APEC

BOP

BPD

BPM5

CBB

COICOP

COFOG

CPI

CSU

DC

DCS

DQAF

DSBB

FPC

GDA

GDDS

GDP

GFS

GFSM 1986

GFSM 2001

HBS

IIP

IMF

ISIC

MFSM

MOF

NPISH

NSI

ODC

OFC

PPI

Reserves template

ROSC

SAFI

SBFE

SDDS

STA

UPF
System of National Accounts 1968

System of National Accounts 1993

Economic Policy Advisory Office, CBB

Balance of Payments

Balance of Payments Department, CBB

Balance of Payments Manual, fifth edition

Central Bank of Bolivia

Classification of Individual Consumption by Purpose

Functional Classification of Government Expenditures

Consumer Price Index

Customer Service Unit, NSI

Depository Corporations

Depository Corporations Survey

Data Quality Assessment Framework, July 2003

Dissemination Standards Bulletin Board

Foreign Private Capital

General Directorate of Accounting, MOF

General Data Dissemination System

Gross Domestic Product

Government Finance Statistics

A Manual on Government Finance Statistics, 1986

Government Financial Statistics Manual 2001

Household Budget Survey

International Investment Position

International Monetary Fund

International Standard Industrial Classification

Monetary and Financial Statistics Manual

Ministry of Finance

Nonprofit Institutions Serving Households

National Statistics Institute

Other Depository Corporations

Other Financial Corporations

Producer Price Index

International Reserves and Foreign Currency Liquidity Data Template

Report on the Observance of Standards and Codes

Investment Funds Management Societies

Superintendency of Banks and Financial Entities

Special Data Dissemination Standard

Statistics Department, IMF

Fiscal Programming Unit, MOF 


\section{Overall ASSESSMent}

1. The quality of Bolivia's macroeconomic statistics has improved over recent years and the statistics have been broadly adequate for macroeconomic analysis and policy design and monitoring. Nevertheless, the ROSC mission identified shortcomings in some statistical practices that have the potential for detracting from the accurate and timely analysis of economic and financial developments and the formulation of appropriate policies. The authorities have established a good track record of implementing recommendations of technical assistance missions and have demonstrated a commitment to pursue plans and programs to further improve their statistics. The authorities are strongly committed to adhering to internationally accepted standards and good practices, as demonstrated by their participation in the General Data Dissemination System (GDDS) and their forthcoming subscription to the more demanding Special Data Dissemination Standard (SDDS).

2. Bolivia has an effective legal and institutional framework that supports statistical quality. The resources are generally commensurate with the current volume of statistical services, but insufficient to advance the implementation of needed improvements in most datasets. The work of all statistical agencies is based on professionalism, transparency, and adherence to ethical standards. The methodologies for the consumer price index (CPI), monetary, and balance of payments (BOP) statistics are basically sound, but there is room for improving the conceptual framework, scope, classification, and basis for recording in all other datasets. Adequate source data are generally available, except for national accounts and the producer price index (PPI). The reference year for national accounts (1990) has become obsolete and there is excessive use of fixed intermediate consumption/output coefficients. Indirect estimates of illegal production linked to the transformation of the coca leaf, some informal industrial and domestic trade activities, and shuttle trade are made, but related exports are excluded from BOP statistics. Furthermore, the CPI and PPI weights have not been updated during the past 16 years. Most of the official statistics are consistent within each dataset and over a reasonable period of time, but consistency with other datasets needs to be improved for the national accounts. Most datasets meet the periodicity and timeliness recommended by the GDDS, with the GFS, GDP, monetary, and BOP also meeting SDDS requirements.

3. Bolivia participates in the GDDS since November 2000 and meets the recommendations for the coverage, periodicity, and timeliness of most required data categories. However, there are some exceptions, including (a) the periodicity and timeliness of the manufacturing and producer price indexes; (b) the coverage of the consolidated central government operations; and (c) dissemination of data on public and publicly guaranteed debt service schedule. Bolivia compiles and disseminates most encouraged data categories. Exceptions are the debt service schedule of private external debt not publicly guaranteed and the timeliness of data on gross national income, capital formation, and savings. A share price index is not compiled because the volume of transactions in shares in the stock exchange is very small. Appendix I provides an overview of Bolivia's dissemination practices compared to the GDDS. 
4. In applying the current version of the IMF's DQAF (July 2003), the remainder of this section presents the mission's main conclusions. The presentation is done at the level of the DQAF's quality dimensions, by agency for the first two dimensions and across datasets for the remaining four.

\section{Prerequisites of quality and assurances of integrity:}

- The National Statistical Institute (NSI) has a legal and institutional environment that supports the production and dissemination of national accounts and price statistics. The laws establish mandatory data reporting by public and private entities to the NSI and the confidential nature of individual information, but no sanctions or fines are specified for noncompliance. Resources should be strengthened to establish a regular program of economic surveys for national accounts and to improve the quality of the PPI. Formal mechanisms to consult data users need to be strengthened. The NSI applies strict technical principles and professional ethics in the compilation and dissemination of statistics, and promotes a culture of professionalism. The terms and conditions under which statistics are produced are not available on the NSI website, but various publications reproduce the relevant legal precepts. Information on internal government access to data before their release to the public is only disseminated on the IMF's DSBB. The legal framework establishes sanctions for improper behavior of public servants in the performance of their functions, and these regulations are made known to the staff.

- The Ministry of Finance (MOF) has a legal and institutional environment that supports the compilation and dissemination of government finance statistics (GFS). Data sharing and coordination among and within institutions are broadly adequate, but there is some room for improvement (e.g., by centralizing the compilation and dissemination of GFS). Although resources are commensurate with the current needs of statistical programs, additional personnel and financing resources will be required for developmental work, including the adoption of the Government Finance Statistics Manual 2001. Regular procedures to consult with data users and to monitor the quality of the statistics need to be established. Data are collected, compiled and disseminated on an impartial basis. The MOF promotes a culture of professionalism and is authorized to respond to misinterpretation/misuse of fiscal data. The terms and conditions under which the MOF collects, compiles, and disseminates GFS are specified in relevant laws, which are available to the public. The legislation provides guidelines on staff behavior and administrative procedures, which are well known by the staff.

- The compilation of statistics by the Central Bank of Bolivia (CBB) is based on a legal framework that supports mandatory data reporting and the confidentiality of the reported data. Inter-agency coordination is effective, but there is room for improving the data sharing arrangements with the NSI for the provision of timely survey data for the BOP. Human resources dedicated to the compilation of monetary and BOP statistics are adequate, but insufficient for conducting surveys needed for the BOP. The CBB maintains some informal contacts with data users, but there are no formal mechanisms to monitor the relevance of the statistics or to identify emerging data requirements. The statistics are compiled and disseminated following strict technical criteria and within a 
culture of professionalism. The terms and conditions under which statistics are compiled and disseminated are available to the public. Information on internal government access to data before their release to the public is disseminated on the CBB website and the IMF's DSBB. The CBB's Code of Conduct establishes ethical principles for CBB staff, including integrity, professional independence, and confidentiality. Staff of the CBB must sign at the start of each year a confidentiality agreement concerning the activities and operations of the reporting institutions.

- The Superintendency of Banks and Financial Entities (SBFE) has the legal authority to collect data from all financial intermediaries under its supervision and the laws include penalties in cases of delays or inaccurate reporting. While the SBFE's main function is to collect data for supervisory purposes, it has always demonstrated willingness to meet the CBB's emerging data needs. Technical criteria alone are applied in the selection of data collection methods and processes and activities in the workplace promote a culture of professionalism. The terms and conditions for collecting data for supervisory purposes are specified in the relevant laws, which are available to the public. The SBFE's Ethics Code contains rules on staff conduct, which are known by all staff.

6. The methodologies for the CPI, as well as monetary and BOP statistics broadly follow international standards. However, there are important shortcomings in the methodological soundness of the national accounts, PPI, and GFS, where progress towards adopting the latest statistical manuals has been slower. In general, there is room for improving the scope of all datasets. For example, important economic activities are missing in the PPI, including agriculture, mining, energy, water, gas, and services. For national accounts, the institutional sector accounts are compiled only up to the capital account and the nonprofit institutions serving households sector (NPISH) is not investigated. Indirect estimates of illegal production linked to the transformation of the coca leaf, some informal industrial and domestic trade activities, and shuttle trade are made. The GFS exclude data from some decentralized agencies and local governments and the consolidated central government data are not compiled, even though information is available. Monetary aggregates exclude data for Investment Funds Management Societies, which issue liabilities that should be included in broad money. The BOP excludes unrecorded trade and some other transactions with nonresidents. There is room to improve classification and sectorization systems for all datasets, in particular for GFS, where there are significant departures from best practices, e.g., in the classification of royalties, commissions, tax returns, social assistance benefits, and lending minus repayments. The basis for recording national accounts, prices, and monetary statistics follow international best practices. Recording of transactions for the BOP and GFS could be improved, for example, by fully adopting accrual accounting.

7. While ample source data sustain a high level of accuracy and reliability in the monetary statistics, there is significant room for improvement in all other datasets, especially for national accounts and the PPI. Source data are very good for monetary statistics, are reasonably available for the CPI, but are insufficiently developed for the national accounts, the PPI, GFS, and BOP statistics. Despite recent improvements in the data sources for national accounts, such as the conduct of a household survey, important weaknesses remain. For example, a comprehensive business directory does not exist, the compilation of the 
annual manufacturing, foreign direct investment, and tourism surveys were suspended, and economic censuses are not conducted on a regular basis. With respect to the PPI, the basket is not fully representative of current national output. There is some overlapping of responsibilities in the collection of source data for GFS, and the coverage of certain services and financial transactions in the BOP needs to be expanded. Assessment and validation of source data for GFS, monetary, and BOP statistics are sound, but need to be strengthened for national accounts and price indices. Statistical techniques need to be improved for most datasets. For example, the reference year for national accounts (1990) has become obsolete and there is excessive use of fixed intermediate consumption/output coefficients; CPI and PPI weights have not been updated during the past 16 years and new products are not introduced in the CPI. The procedures for validating intermediate and final data are sound. For the most part, revision studies and analysis are conducted and used to inform the statistical processes. However, only the analyses of revisions to monetary statistics are documented on a systematic basis.

8. Serviceability of the macroeconomic statistics is broadly satisfactory, as confirmed by the results of a user survey conducted in the context of this assessment. With the exception of the PPI and the public and publicly guaranteed debt service schedule, data in all assessed areas are compiled and disseminated with the periodicity and timeliness recommended by the GDDS. Furthermore, all data categories in the GFS, monetary, and BOP datasets, meet the periodicity and timeliness required by the more demanding SDDS. Macroeconomic statistics are broadly consistent within the dataset and can be reconciled over a reasonable period of time. While publicly available information permits the reconciliation of GFS, monetary, and BOP statistics, there is room to improve the consistency of national accounts with other datasets. The statistical agencies have well established revision policies and practices for most datasets, and preliminary and revised data are identified in the publications. However, neither the revision cycle nor the analyses of revisions are publicized.

9. There are opportunities to improve the accessibility of official statistics, for example, by disseminating the advance release calendars on the websites of all statistical agencies and improving access to data via the Internet. Currently, the advance release calendar for all the assessed datasets is disseminated on the CBB website. A government policy advisory committee is provided with data that may or may not be disseminated to the public. However, this practice does not affect the pre-scheduled release. Detailed metadata are posted on the websites of the statistical agencies and in the publications, with the exception of metadata for GFS, which are only available on the IMF's DSBB. All data-producing agencies provide effective assistance to users.

10. At the request of the authorities, current data dissemination practices were also reviewed against the requirements of the Special Data Dissemination Standard (SDDS). ${ }^{1}$ The following points about the coverage, periodicity, and timeliness prescriptions of the data

\footnotetext{
${ }^{1}$ A detailed description of the SDDS can be found on the IMF's Data Standards Bulletin Board (DSBB) on the Internet at http://www.dsbb.imf.org. A summary is presented in Appendix II of the Detailed Assessment document.
} 
dimension highlight some significant issues to be addressed prior to subscription to the SDDS:

- In the real sector,

i. Data on employment, unemployment, and wages/salaries need to be compiled on a quarterly basis and disseminated within three months after the end of the reference period. While data for public sector employment and wages/salaries meet the SDDS standard, data for the private sector are only compiled every six months and disseminated with a four-month lag. Data on unemployment are only compiled on an annual basis and disseminated with a four-month lag; and

ii. The PPI needs to be compiled on a monthly basis and disseminated within a month of the end of the reference period. Currently, the PPI is compiled on a quarterly basis and disseminated with a ten-week lag.

- In the fiscal sector, the consolidated operations of the central government (budgetary, extrabudgetary, and social security operations) are not compiled, even though the data for the component subsectors are available. Data on the consolidated operations of the general government and the nonfinancial public sector are compiled and disseminated.

- All data categories in the financial and external sectors meet the SDDS prescriptions on coverage, periodicity, and timeliness.

11. Advanced release calendars for all data categories are disseminated at: http://www.bcb.gov.bo/sitio/estadisticast.php?n2=5\&n3=9\&n4. Appendix III in the accompanying document presents a more detailed description of current practices regarding coverage, periodicity, and timeliness of data compared to the SDDS.

12. Bolivia should be able to meet the remaining requirements for SDDS subscription in the very short term, particularly because the country is entitled to take two flexibility options. This means that for any two prescribed data categories listed above (employment, unemployment, wages/salaries, and the producer price index), periodicity and/or timeliness may be less than prescribed. ${ }^{2}$

\section{ASSeSSment by AgenCy AND DAtaset}

13. Assessment of the quality of six macroeconomic datasets - national accounts, consumer price index, producer price index, government finance, monetary, and balance of payments statistics - were conducted using the July 2003 vintage of the DQAF. In this section, the results are presented at the level of the DQAF elements and using a four-point rating scale (Table 1). Assessments of the prerequisites of data quality and the assurances of integrity (Dimensions " 0 " and " 1 " of the DQAF) are presented in Tables $2 \mathrm{a}-\mathrm{d}$. For each

\footnotetext{
${ }^{2}$ For a detailed description of the flexibility options see the Guide to the Data Dissemination Standards, 1996 (56-59).
} 
dataset, the assessment of methodological soundness, accuracy and reliability, serviceability, and accessibility (Dimensions "2" to "5" of the DQAF) are shown in Tables 3a-f.

14. In order to complement the Fund's assessment of the quality of official statistics, the mission conducted an informal survey of key users of macroeconomic statistics.

Questionnaires were sent to a broad range of users who were asked to evaluate key aspects of data quality. Surveys were sent to 329 targeted users, with 85 of them submitting responses, including the main users of official statistics.

15. On a five point scale $(1=$ poor and $5=$ excellent $)$, the average rating for the overall quality of official statistics for all sectors was 3.5. A majority of the respondents expressed satisfaction with the methodological soundness of the data and believed that Bolivia's statistics were comparable to the statistics disseminated by neighboring countries. Respondents also indicated that they were satisfied with the level of coverage and detail as well as the periodicity. However, respondents expressed general dissatisfaction with the accessibility to metadata and timeliness, particularly of national accounts.

16. Several respondents suggested that the level of detail of economic statistics be expanded by disseminating, for example, GDP by region. In addition, users expressed interest in a producer price index, increased periodicity of labor statistics, and forward looking indicators of economic activity. A more detailed analysis of the Users' Survey and the tabulated results are included in Appendix IV of the accompanying document Detailed Assessments Using the Data Quality Assessment Framework (DQAF). 
Table 1. Bolivia: Data Quality Assessment Framework July 2003-Summary Results

\begin{tabular}{|c|c|c|c|c|c|c|}
\hline $\begin{array}{lc} & \text { Datasets } \\
\text { Dimensions/Elements } & \\
\end{array}$ & $\begin{array}{l}\text { National } \\
\text { Accounts }\end{array}$ & $\begin{array}{l}\text { Consumer Price } \\
\text { Index }\end{array}$ & $\begin{array}{l}\text { Producer Price } \\
\text { Index }\end{array}$ & $\begin{array}{l}\text { Government } \\
\text { Finance } \\
\text { Statistics }\end{array}$ & $\begin{array}{l}\text { Monetary } \\
\text { Statistics }\end{array}$ & $\begin{array}{l}\text { Balance of } \\
\text { Payments } \\
\text { Statistics }\end{array}$ \\
\hline \multicolumn{7}{|l|}{ 0. Prerequisites of quality } \\
\hline 0.1 Legal and institutional environment & $\mathrm{LO}$ & $\mathrm{O}$ & $\mathrm{O}$ & $\mathrm{LO}$ & $\mathrm{O}$ & LO \\
\hline 0.2 Resources & $\mathrm{LO}$ & LO & LNO & LO & LO & LO \\
\hline 0.3 Relevance & LO & LO & LO & LNO & LO & LO \\
\hline 0.4 Other quality management & $\mathrm{O}$ & $\mathrm{O}$ & $\mathrm{O}$ & $\mathrm{O}$ & $\mathrm{O}$ & $\mathrm{O}$ \\
\hline \multicolumn{7}{|l|}{ 1. Assurances of integrity } \\
\hline 1.1 Professionalism & $\mathrm{O}$ & $\mathrm{O}$ & $\mathrm{O}$ & $\mathrm{O}$ & $\mathrm{O}$ & $\mathrm{O}$ \\
\hline 1.2 Transparency & LO & LO & $\mathrm{O}$ & LO & $\mathrm{O}$ & $\mathrm{O}$ \\
\hline 1.3 Ethical standards & $\mathrm{O}$ & $\mathrm{O}$ & $\mathrm{O}$ & $\mathrm{O}$ & $\mathrm{O}$ & $\mathrm{O}$ \\
\hline \multicolumn{7}{|l|}{ 2. Methodological soundness } \\
\hline 2.1 Concepts and definitions & LO & LO & LO & LO & $\mathrm{O}$ & $\mathrm{O}$ \\
\hline 2.2 Scope & $\mathrm{LO}$ & $\mathrm{O}$ & LNO & LO & LO & LO \\
\hline 2.3 Classification/sectorization & LO & LO & LO & LNO & LO & LO \\
\hline 2.4 Basis for recording & $\mathrm{O}$ & $\mathrm{O}$ & $\mathrm{O}$ & LO & $\mathrm{O}$ & LO \\
\hline \multicolumn{7}{|l|}{ 3. Accuracy and reliability } \\
\hline 3.1 Source data & LNO & $\mathrm{O}$ & LNO & LO & $\mathrm{O}$ & LO \\
\hline 3.2 Assessment of source data & LO & LO & LO & $\mathrm{O}$ & $\mathrm{O}$ & $\mathrm{O}$ \\
\hline 3.3 Statistical techniques & LNO & LNO & LNO & $\mathrm{O}$ & $\mathrm{O}$ & LO \\
\hline 3.4 Assessment and validation of intermediate & & & & & & \\
\hline data and statistical outputs & $\mathrm{O}$ & $\mathrm{O}$ & $\mathrm{O}$ & $\mathrm{O}$ & $\mathrm{O}$ & $\mathrm{O}$ \\
\hline 3.5 Revision studies & LO & LO & LO & LO & $\mathrm{O}$ & LO \\
\hline \multicolumn{7}{|l|}{ 4. Serviceability } \\
\hline 4.1 Periodicity and timeliness & $\mathrm{O}$ & $\mathrm{O}$ & LNO & $\mathrm{O}$ & $\mathrm{O}$ & $\mathrm{O}$ \\
\hline 4.2 Consistency & LO & $\mathrm{O}$ & $\mathrm{O}$ & LO & $\mathrm{O}$ & LO \\
\hline 4.3 Revision policy and practice & LO & LO & LO & LO & LO & LO \\
\hline \multicolumn{7}{|l|}{ 5. Accessibility } \\
\hline 5.1 Data accessibility & LO & LO & LO & LO & $\mathrm{LO}$ & $\mathrm{O}$ \\
\hline 5.2 Metadata accessibility & $\mathrm{O}$ & $\mathrm{O}$ & $\mathrm{O}$ & LO & $\mathrm{O}$ & $\mathrm{O}$ \\
\hline 5.3 Assistance to users & $\mathrm{O}$ & $\mathrm{O}$ & $\mathrm{O}$ & $\mathrm{O}$ & $\mathrm{O}$ & $\mathrm{O}$ \\
\hline
\end{tabular}

Practice observed: current practices generally in observance meet or achieve the objectives of DQAF internationally accepted statistical practices without any significant deficiencies. Practice largely observed: some departures, but these are not seen as sufficient to raise doubts about the authorities' ability to observe the DQAF practices. Practice largely not observed: significant departures and the authorities will need to take significant action to achieve observance. Practice not observed: most DQAF practices are not met. Not applicable: used only exceptionally when statistical practices do not apply to a country's circumstances. 


\section{Prerequisites of quality}

Legal and institutional environment. Provisions for producing statistics are included in the DL 14100, from November 5, 1976, that created the National Statistical Information System. The Supreme Decree 21855, from January 14, 1988, transferred the compilation of the national accounts from the CBB to NSI. Article 15 of DL 14100 establishes mandatory data reporting by public and private entities to the NSI. Although Article 21 establishes the confidential nature of individual information, no sanctions or fines are specified for noncompliance. NSI has signed special agreements with various institutions to facilitate data sharing and coordination.

Resources. While some resources have been allocated to modernize the national accounts, additional resources are required to strengthen the data collection and compilation program. The staff, computing, and financing resources are adequate for the regular compilation of CPI, but inadequate for the PPI. Staff performance is reviewed every six months.

Relevance. The NSI does not have formal mechanisms to consult data users on their information needs. However, the Institute strives to adopt best international practices.

Other quality management. The Institutional Strategic Plan for 2005-2009 aims to obtain the ISO 9000:2000 quality certification for the NSI's main statistical products. The authorities strongly support the adoption of international manuals and guides and seek technical and financial support in that regard.

\section{Assurances of integrity}

Professionalism. NSI's Statistical Principle of Integrity clearly states the importance of applying technical principles and professional ethics in the compilation and dissemination of statistics. Professionalism is promoted, among other measures, by sending compilers to training courses and specialized seminars abroad, and by receiving technical assistance from other countries and international organizations. The National Accounts Directorate monitors media coverage of national accounts data and the NSI is entitled to comment when statistics are misinterpreted or misused.

Transparency. Although the legislation governing the terms and conditions under which statistics are produced by the NSI is not available on its website, various publications and documents disseminated through the website reproduce the relevant legal precepts. Major changes in the conceptual framework, source data, and statistical techniques of the national accounts were announced in advance (e.g., the introduction of the base year 1990). Metadata for quarterly GDP, institutional sector accounts, and others are disseminated on the website. An advance release calendar is provided to the public. Data released to the public are clearly identified as NSI's product by name and logo. Information on internal government access to data before their release to the public is disseminated on the IMF's DSBB but not on the NSI website. Adequate documentation is available on the methodology used for compiling price indices.

Ethical standards. The Law No. 2027 on Public Servants and the NSI's Staff Regulation establish sanctions for improper behavior of public servants in the performance of their functions. These regulations are made known to the staff. 


\section{Prerequisites of quality}

Legal and institutional environment. The MOF has a legal and institutional environment that supports the collection, compilation, and dissemination of GFS, budget, and accounting data. This responsibility is assigned to the MOF by the Law on Organization of the Executive Branch, known as the "LOPE" (Law N 3351 of March 9, 2006) and the Law of Government Administration and Control, known as the "SAFCO" (Law No. 1178 of July 20,1990), and its subsequent by-laws and regulations. The Fiscal Programming Unit (UPF) in the MOF is in charge of GFS compilation, though this responsibility is shared with the General Directorate of Accounting (GDA). Data sharing and coordination among and within institutions are adequate, but there is some room for improvement (e.g., by centralizing the compilation and dissemination of GFS). The UPF compiles above-the-line data and the CBB compiles below-the-line data, and both share the compilation and dissemination of public debt data. The GDA compiles GFS following the GFSM 2001 methodology for publication in the IMF GFS Yearbook. The current legislation and procedures require that each public entity submits budgetary and financial statements to the MOF. The laws specify penalties for noncompliance.

Resources. Although resources are commensurate with the current needs of statistical programs, additional personnel and financing resources could be required to perform new compilation tasks, such as the expansion of the institutional and transaction coverage of the GFS already compiled, and the implementation of the GFSM 2001 analytical framework.

Relevance. Regular procedures to consult with data users and to monitor the quality of the statistics need to be established.

Other quality management. There are processes in place to focus on and monitor quality, and to deal with quality considerations in the planning of the statistical program.

\section{Assurances of integrity}

Professionalism. There are no specific laws or other formal provisions that explicitly address professional independence or prohibit political interference. Nevertheless, government finance statistics are compiled on an impartial basis. A culture of professionalism is clearly recognized as essential to the credibility of statistical results in the internal provisions of the MOF and in the principles of Law on Public Servants of October 27, 1999 (Law No. 2027) and its by-laws and provisions. The choice and tenure of the managers are based on an independent process. Efforts are made to promote professionalism by sending staff to training courses abroad and by on-the-job training. Also, professionalism is fostered by analytical work, publication of methodological papers, and organization of lectures and seminars. Research and analysis are encouraged and the result of these academic activities are published on the MOF website. No evidence exists of political interference in the choice of data sources and statistical methods and decisions about dissemination. The MOF is empowered to respond to misinterpretation/misuse of fiscal data.

Transparency. Current legislation establishes that the public has unimpeded access to the fiscal data. The terms and conditions under which the MOF collects, compiles, and disseminates GFS are specified in the relevant laws, which are available to the public. All fiscal data products are disseminated through the MOF website and Statistical Bulletin, but do not clearly identify the compiling agencies and data sources. Advance notice is not given to the public about major changes in the methodology or other relevant changes that materially affect the GFS.

Ethical standards. Staff behavior is guided by law and administrative procedures of the civil service, which are made known to the staff. 
Table 2c. Bolivia: Assessment of Data Quality—Dimensions 0 and $1-$ Central Bank of Bolivia

\section{Prerequisites of quality}

Legal and institutional environment. Provisions for producing statistics are included in the Law 1670/95 (Law of the Central Bank of Bolivia) that contains: (1) the obligation of the Superintendency of Banks and Financial Entities (SBFE) to provide the CBB with all the information received from banks and other entities of the financial sector (art. 40);

(2) mandatory data reporting directly to the CBB of all information requested by it from banks and other financial intermediaries (art. 40); (3) the CBB's responsibility for recording public and private sector external debt (art. 21); (4) strict confidentiality of the received information (art. 80); and, (5) provisions governing the publication of economic and financial data (art. 43). Institutional arrangements are in place for effective transmission of source data from the SBFE (monetary) and the NSI (balance of payments) to the CBB. However, some data sharing arrangements with the NSI have not provided effective and timely survey data. The Law 1670/95 does not include any specific regulation establishing that the CBB is responsible for compiling and disseminating balance of payments data. However, the CBB is publicly recognized as the sole institution with these responsibilities and has disseminated balance of payments statistics since 1938 .

Resources. Human resources dedicated to the compilation of monetary and balance of payments statistics are adequate, but insufficient for balance of payments surveys. Technical resources and data processing equipment are adequate, but compilers have limited telephone communication and Internet access. A recent presidential decree reducing public service salaries may negatively affect staffing.

Relevance. The CBB does not have formal mechanisms to consult data users about their information needs, but users' feedback are taken into account to improve the statistical processes. The CBB shows its commitment to improve the country's macroeconomic statistics by participating in statistical meetings and seminars organized by international and regional organizations.

Other quality management. The CBB's authorities are aware that continued efforts are needed to improve the quality of the statistics produced by the Bank, as shown in their request for IMF technical assistance in monetary statistics and flow of funds accounts. The compilation and dissemination of quarterly balance of payments, IIP, private sector debt data, and monthly reserves template data, as well as the country's efforts to subscribe to the SDDS, further demonstrate this commitment.

\section{Assurances of integrity}

Professionalism. Monetary and balance of payments statistics are compiled and disseminated following strict technical criteria, and with professional independence. When statistics are misinterpreted or misused the CBB provides comments and clarifications mainly through its Institutional Communications Department.

Transparency. The terms and conditions under which statistics are compiled and disseminated are widely available to the public. Internal government access to data before their release to the public is acknowledged on the CBB website and the IMF's DSBB. Changes in methodology and source data are described in the semiannual CBB's External Sector Bulletin. Usually, advance notice is given for major changes in balance of payments statistics.

Ethical standards. The CBB's Code of Conduct establishes ethical principles for CBB staff, including integrity, professional independence, and confidentiality. The CBB's Internal Staff Regulation establishes staff's rights and obligations. As part of the public sector, the CBB staff is also subject to Law 2027/99 on Public Servants, which sets out the legal framework for their rights and responsibilities. Pursuant to art. 80 of the Law $1670 / 95$, staff of the CBB must sign at the start of each year a confidentiality agreement concerning the activities and operations of the reporting institutions. 
Table 2d. Bolivia: Assessment of Data Quality—Dimensions 0 and 1-Superintendency of Banks and Financial Entities

\section{Prerequisites of quality}

Legal and institutional environment. Law 1488/93 (Law of Banks and Financial Institutions) endows the SBFE with the authority to request from all financial intermediaries information on their financial situation and operations (art. 93). Article 99 of the same law contemplates penalties in cases of delays or inaccurate reporting, with fines of around US\$62 per day for noncompliance. Articles 86 and 89 of law $1488 / 95$ protect the confidentiality of the reported data. Other depository corporation (ODCs) transmit daily to the SBFE, in electronic format, their balance sheets of the previous day, plus data on interest rates. ODCs transmit to the SBFE their monthly balance sheets and sectorized accounts for monetary statistics purposes two days after the end of the reference month. Institutional arrangements are in place for electronic data transmission from the SBFE to the CBB. Data are transmitted from the ODCs to the SBFE, and from the SBFE to the CBB, via dedicated encrypted lines.

Resources. Human, technical, and financial resources are adequate. Salaries in the SBFE have been historically higher than in the rest of the public sector and broadly competitive with the private sector, contributing to low staff turnover ratio. However, a recent presidential decree reducing public service salaries and flattening the salary scale may negatively affect staffing. Several senior SBFE staff have recently left for the private sector.

Relevance. The SBFE's main function is to collect data for supervisory purposes. Nevertheless, the SBFE has always demonstrated willingness to accommodate CBB's emerging data needs for the compilation of monetary statistics, for example, by requesting additional information from the ODCs and introducing ad-hoc changes to the chart of accounts. Staff of the SBFE regularly attend meetings and participate in international courses offered by other supervisory agencies and central banks.

Other quality management. The SBFE's authorities are aware that continued efforts are needed to improve the quality of its statistical products.

\section{Assurances of integrity}

Professionalism. The SBFE is a technical institution that has administrative and financial autonomy. Technical criteria alone are applied by data compilers and analysts, and they are totally independent in their choice of data collection methods. Processes and activities in the workplace promote a culture of professionalism.

Transparency. The legal terms and conditions for collecting data for supervisory purposes are specified in the relevant laws, which are available to the public. Government officials outside the SBFE have no access to the data until it is released to the general public. The SBFE statistical products are clearly identified as such. Information of public nature, such as balance sheets of ODCs, are available on the SBFE's website and its monthly Boletín Informativo, which also contains data on interest rates, financial soundness indicators, deposits and loans by volume, sectoral distribution of loans, etc. The SBFE also publishes a weekly letter containing an analytical description of the financial sector.

Ethical standards. SBFE staff receive a copy of the Ethics Code, which contains rules on their conduct regarding truthfulness, respect to individuals, responsibility, transparency, integrity, and confidentiality. 
Table 3a. Bolivia: Assessment of Data Quality-Dimensions 2 to 5-National Accounts

\begin{tabular}{|c|c|c|c|}
\hline 2. Methodological soundness & 3. Accuracy and reliability & 4. Serviceability & 5. Accessibility \\
\hline $\begin{array}{l}\text { Concepts and definitions. The national } \\
\text { accounts are compiled following the } \\
1968 \text { SNA. However, some important } \\
\text { features of the } 1993 \text { SNA have been } \\
\text { incorporated. } \\
\text { Scope. The accounts cover annual and } \\
\text { quarterly GDP by the expenditure and } \\
\text { production approaches at current and } \\
\text { constant } 1990 \text { prices, annual GDP by the } \\
\text { income approach at current prices, and } \\
\text { annual supply and use. Also, a } \\
\text { seasonally adjusted quarterly GDP is } \\
\text { compiled. Indirect estimates of illegal } \\
\text { production linked to the transformation } \\
\text { of the coca leaf, some informal industrial } \\
\text { and domestic trade activities, and shuttle } \\
\text { trade are made. The scope also includes } \\
\text { institutional sector accounts from the } \\
\text { production up to the capital account. } \\
\text { Classification/sectorization. National } \\
\text { classifications of economic activities and } \\
\text { products are based on ISIC Rev. } 3 \\
\text { (except for agriculture) and the CPC, } \\
\text { respectively. The COICOP is applied to } \\
\text { classify households' consumption } \\
\text { expenditure by purpose. COFOG is not } \\
\text { applied. } \\
\text { Basis for recording. Transactions are } \\
\text { recorded on an accrual basis. } \\
\text { Preliminary estimates of government } \\
\text { transactions are registered on a cash } \\
\text { basis, but later adjusted to accrual. } \\
\text { Transactions among subsidiaries of the } \\
\text { same corporation are recorded on a gross } \\
\text { basis. }\end{array}$ & $\begin{array}{l}\text { Source data. The availability of economic } \\
\text { statistics has deteriorated in recent years } \\
\text { due to the suspension of various important } \\
\text { surveys. Price and volume indices based on } \\
\text { the quarterly manufacturing survey have } \\
\text { lost coverage due to its outdated } 1990 \text { fixed } \\
\text { basket of products. The availability of price } \\
\text { statistics is limited. Economic and } \\
\text { households surveys were recently } \\
\text { conducted to update the base year for } \\
\text { national accounts and the CPI. } \\
\text { Assessment of source data. Sampling } \\
\text { errors are not estimated in some surveys. } \\
\text { Source data are principally assessed in the } \\
\text { context of revisions. } \\
\text { Statistical techniques. Sound techniques } \\
\text { are employed to adjust for scarce data } \\
\text { sources. The } 1990 \text { base year is outdated. } \\
\text { Due to limited source data, excessive use } \\
\text { of fixed } 1990 \text { coefficients is made in the } \\
\text { compilation of supply and use tables. } \\
\text { Changes in inventories are obtained as } \\
\text { residuals. The treatment of pension funds } \\
\text { and the techniques applied to estimate } \\
\text { financial intermediation services indirectly } \\
\text { measured (FISIM) at constant prices could } \\
\text { be improved. } \\
\text { Assessment and validation of } \\
\text { intermediate data and statistical outputs. } \\
\text { Intermediate data and outputs are assessed } \\
\text { and validated against available information. } \\
\text { Revision studies. Analyses of revisions are } \\
\text { carried out and documented. However, } \\
\text { revision studies are conducted only on an } \\
\text { ad-hoc basis. }\end{array}$ & $\begin{array}{l}\text { Periodicity and timeliness. } \\
\text { While preliminary GDP data } \\
\text { meet GDDS recommendations } \\
\text { on periodicity and timeliness, } \\
\text { users have expressed an } \\
\text { urgent need to improve } \\
\text { timeliness. } \\
\text { Consistency. Internal and } \\
\text { intertemporal consistency of } \\
\text { GDP figures are verified in } \\
\text { the framework of Supply and } \\
\text { Use tables, compiled at } \\
\text { current and constant prices. } \\
\text { Quarterly GDP estimates are } \\
\text { consistent with annual } \\
\text { estimates. Consistency with } \\
\text { BOP and GFS is not verified } \\
\text { on a regular basis and may be } \\
\text { affected by the lack of } \\
\text { estimates of illegal trade in } \\
\text { BOP statistics. } \\
\text { Revision policy and practice. } \\
\text { Revisions follow a regular } \\
\text { schedule. The revision cycle is } \\
\text { predetermined and stable from } \\
\text { year to year, but is not } \\
\text { publicized. Preliminary data } \\
\text { are clearly identified, but not } \\
\text { revised data. Documentation } \\
\text { on analysis of revisions and a } \\
\text { revision study made for the } \\
\text { construction activity are } \\
\text { prepared but not disseminated. }\end{array}$ & $\begin{array}{l}\text { Data accessibility. National } \\
\text { accounts are disseminated on the } \\
\text { NSI website and publications. } \\
\text { They include tables and charts, as } \\
\text { well as analysis. An advance } \\
\text { release calendar is posted on the } \\
\text { CBB website. A government } \\
\text { policy advisory committee is } \\
\text { provided with data that may or } \\
\text { may not have been disseminated } \\
\text { to the public. However, this } \\
\text { practice does not affect the pre- } \\
\text { scheduled release. } \\
\text { Metadata accessibility. Metadata } \\
\text { on various national accounts } \\
\text { components are posted on the NSI } \\
\text { website. } \\
\text { Assistance to users. Specific } \\
\text { contact points are provided on the } \\
\text { NSI website, but not on the } \\
\text { publications. A virtual library and } \\
\text { a catalog of publications are on } \\
\text { the website and in the NSI Central } \\
\text { Library. Photocopies and printouts } \\
\text { of tables are available to the } \\
\text { public upon request. The public } \\
\text { may subscribe to receive } \\
\text { information by e-mail. }\end{array}$ \\
\hline
\end{tabular}


Table 3b. Bolivia: Assessment of Data Quality-Dimensions 2 to 5-Consumer Price Index

\section{Methodological soundness}

Concepts and definitions. The CPI follows the 1968 SNA household consumption concept and uses sufficiently detailed expenditure data from the 1990 Household Budget Survey (HBS). There is an adequate level of detail for both goods and services. The new HBS to update the CPI weights follows the 1993 SNA.

Scope. The CPI is calculated at the national level and for the four largest cities in the country (La Paz, Santa Cruz, Cochabamba, and El Alto). The CPI weights are representative only of consumption by urban households. The new CPI will include six additional cities.

Classification/sectorization. Goods and services are classified using an adaptation of the classification of

consumption expenditure of households by purpose, in accordance with the 1968 SNA. The index is calculated by city for nine headings and 25 groups at the national level. The products of the new CPI basket will be classified using the COICOP

Basis for recording. The prices are market prices paid by households at the points of sale at which transactions are conducted and are inclusive of all taxes on goods and services.

\section{Accuracy and reliability}

Source data. The 1990 HBS was used for the CPI weights. Some 15,500 monthly prices from 332 items (goods and services) are collected in direct interviews at different points of sale, representing the places where consumers do their purchases. The 2003/2004 HBS will be used to derive the new CPI weights. Some 31,700 monthly prices from 508 items will be collected.

Assessment of source data. Data are checked for logical consistency using manual and automated validation methods, including routine checks for extreme values. The share of consumption expenditure not covered by the index is 10 percent. Response rates, editing rates, and sampling errors are not calculated.

Statistical techniques. CPI uses the Lowe formula. Procedures for imputation are no sound. Weights have not been updated for the past 16 years. The current weight and price reference periods are not the same.

\section{Assessment and validation of}

\section{intermediate data and statistical}

outputs. CPI is subject to validation with

respect to primary data from individual

price observations and to the different

levels of aggregation.

Revision studies. Analyses of revisions are conducted but revision studies are not performed.
4. Serviceability

Periodicity and timeliness.

Periodicity and timeliness meet GDDS

recommendations. The index is published the first business day after the reference month. There are some advance releases (three per month) at shorter intervals for internal use.

Consistency. Price statistics are consistent over time and all-items index tabulations are consistent with the different aggregations. A chained index between old and new series is available.

\section{Revision policy and} practice. The monthly $\mathrm{CPI}$ is disseminated as final.

However, bias for changes in the structure of weights are not revised.

\section{Accessibility}

Data accessibility. The CPI is disseminated via press releases and posted on the NSI website. Detailed tables cover the country and four main cities. They contain indices and percentage changes by chapters, groups, and subgroups. A government policy advisory committee is provided with data that may or may not have been disseminated to the public. However, this practice does not affect the pre-cheduled release. Data are released according to a well established calendar, which is disseminated on the $\mathrm{CBB}$ website.

\section{Metadata accessibility}

Concepts, methodology, and data sources for CPI compilation are available to users on the NSI website.

Assistance to users. The NSI provides contact information on the website and publications.

Assistance is provided to users by responding to queries and providing photocopies and printouts of tables. Data are available by subscription or upon request. 


\begin{tabular}{|c|c|c|c|}
\hline 2. Methodological soundness & 3. Accuracy and reliability & 4. Serviceability & 5. Accessibility \\
\hline $\begin{array}{l}\text { Concepts and definitions. The PPI } \\
\text { weights of manufacturing goods are } \\
\text { based on the value of gross output, } \\
\text { excluding intermediate input, and } \\
\text { are in broad conformity with the } \\
\text { guidelines in the } 1968 \text { SNA and the } \\
\text { PPI Manual. The survey to update } \\
\text { the PPI weights was conducted in } \\
2005 \text { and follows the } 1993 \text { SNA. } \\
\text { Scope. The PPI includes prices for } \\
35 \text { groups of manufacturing } \\
\text { industries. The share of goods } \\
\text { output by economic activity not } \\
\text { covered by the index is } 15 \text { percent. } \\
\text { Geographic coverage is nationwide, } \\
\text { excluding Pando. The PPI excludes } \\
\text { economic activities, such as } \\
\text { agriculture, forestry, mining and } \\
\text { quarrying, power, water, gas, } \\
\text { construction, and commercial and } \\
\text { other services. } \\
\text { Classification/sectorization. ISIC } \\
\text { rev. } 2 \text { is used for classifying the } \\
\text { manufacturing industry producer } \\
\text { price index (IPPIM). The index is } \\
\text { disaggregated by group of activity } \\
\text { (four digits), grouping (three } \\
\text { digits), and industrial division (two } \\
\text { digits). } \\
\text { Basis for recording. Market prices } \\
\text { of manufactured goods are used. } \\
\text { Prices of goods and services are } \\
\text { recorded in the period they are } \\
\text { purchased. }\end{array}$ & $\begin{array}{l}\text { Source data. The principal source for } \\
\text { constructing the PPI baskets was the } \\
\text { Annual Economic Survey (1990). } \\
\text { Coverage by group of economic activity } \\
\text { consists of those groups that generate } \\
85 \text { percent of the value added of the } \\
\text { manufacturing industry and, within each } \\
\text { group, those products that represent more } \\
\text { than } 70 \text { percent of the gross value of } \\
\text { output. Quarterly prices of } 125 \text { generic } \\
\text { products are collected through direct } \\
\text { interviews of } 313 \text { establishments. The PPI } \\
\text { basket is not fully representative of current } \\
\text { national output. Source data are not timely. } \\
\text { Assessment of source data. The PPI is } \\
\text { subject to validation with respect to } \\
\text { individual prices and the different levels of } \\
\text { aggregation. The intermediate results for } \\
\text { the PPI are validated against those reported } \\
\text { for the CPI. Response rates to price } \\
\text { surveys and sampling errors are not } \\
\text { calculated. } \\
\text { Statistical techniques. Missing prices are } \\
\text { imputed. PPI uses the Laspeyres formula. } \\
\text { Weights have not been updated in } 16 \text { years. } \\
\text { Assessment and validation of } \\
\text { intermediate data and statistical } \\
\text { outputs. The PPI is validated with } \\
\text { individual prices and different levels of } \\
\text { aggregation. } \\
\text { Revision studies. Analysis of revisions is } \\
\text { conducted but revision studies are not } \\
\text { performed. }\end{array}$ & $\begin{array}{l}\text { Periodicity and timeliness. } \\
\text { Neither periodicity nor timeliness } \\
\text { meet GDDS recommendations. } \\
\text { The PPI is compiled on a } \\
\text { quarterly basis and disseminated } \\
10 \text { weeks after the end of the } \\
\text { reference quarter. } \\
\text { Consistency. The current } \\
\text { quarterly PPI has been published } \\
\text { consistently since December } \\
\text { 1985. Price statistics are } \\
\text { consistent over time and all items } \\
\text { index tabulations are consistent } \\
\text { with the different aggregations. A } \\
\text { chained index between old and } \\
\text { new series is available. } \\
\text { Revision policy and practice. } \\
\text { Newly released PPI data are } \\
\text { preliminary and final data are } \\
\text { published after 2-3 quarters. } \\
\text { Revisions do not follow a regular } \\
\text { schedule. Preliminary data are } \\
\text { clearly identified, but not revised } \\
\text { data. Studies and analyses of } \\
\text { revisions are not made public. }\end{array}$ & $\begin{array}{l}\text { Data accessibility. The PPI is } \\
\text { disseminated quarterly through the } \\
\text { Short-term Economic Indicators } \\
\text { published by the NSI and annually } \\
\text { in the Statistical Yearbook. Data are } \\
\text { also available via the Customer } \\
\text { Service Unit (CSU). Detailed tables } \\
\text { contain indices by division, } \\
\text { grouping, and group of } \\
\text { manufacturing activity. An advance } \\
\text { release calendar is not available. } \\
\text { Metadata accessibility. } \\
\text { Methodologies on the PPI are } \\
\text { available to users in the NSI } \\
\text { publication, Indice de Precios, } \\
\text { Productor Industrial } \\
\text { Manufacturero Sistema de } \\
\text { Metadatos. This document is posted } \\
\text { on the NSI website. } \\
\text { Assistance to users. A contact } \\
\text { point is provided on the NSI } \\
\text { website. CSU also provides } \\
\text { assistance to users by responding to } \\
\text { queries and providing photocopies } \\
\text { and printouts of tables upon } \\
\text { request. The data are also available } \\
\text { to the public at the NSI Central } \\
\text { Library. }\end{array}$ \\
\hline
\end{tabular}




\begin{tabular}{|c|c|c|c|}
\hline 2. Methodological soundness & 3. Accuracy and reliability & 4. Serviceability & 5. Accessibility \\
\hline $\begin{array}{l}\text { Concepts and definitions are broadly } \\
\text { consistent with the recommendations of } \\
\text { the GFSM } 1986 \text {. The authorities have } \\
\text { not yet prepared a plan to migrate to the } \\
\text { GFSM } 2001 \text {. } \\
\text { Scope for institutional and transaction } \\
\text { coverage is incomplete because } \\
\text { detailed data of some decentralized } \\
\text { units and some local governments are } \\
\text { not collected. } \\
\text { Classification/sectorization. } \\
\text { Departures from the GFSM 1986 } \\
\text { include: (1) consolidated central } \\
\text { government data are not compiled, } \\
\text { even though information is available; } \\
\text { (2) misclassification of royalties, } \\
\text { commissions for interest, tax returns, } \\
\text { social assistance benefits, and lending } \\
\text { minus repayment; (3) some data are not } \\
\text { disaggregated; and (4) classification of } \\
\text { tax revenues, financing, and debt do not } \\
\text { strictly follow international } \\
\text { recommendations. } \\
\text { Basis for recording. Mostly done on a } \\
\text { cash basis, but some adjustments to } \\
\text { accrual are made. Flows are valued at } \\
\text { market prices and financial stocks at } \\
\text { nominal or face value. Grossing/netting } \\
\text { procedures are not fully consistent with } \\
\text { international standards. }\end{array}$ & $\begin{array}{l}\text { Source data for GFS are: (1) the Integrated } \\
\text { System of Management and Administrative } \\
\text { Modernization; (2) the integrated system of } \\
\text { accounting; (3) the UPF system; (4) the } \\
\text { External Debt Management and Financial } \\
\text { Analysis System; and (5) independent } \\
\text { systems of some public units. These systems } \\
\text { are not fully integrated, which leads to undue } \\
\text { burden in data collection and compilation. } \\
\text { Institutional coverage is incomplete. Data } \\
\text { sources are timely and reasonably } \\
\text { approximate the recommended definitions, } \\
\text { scope, classifications, valuations, and basis of } \\
\text { recording. } \\
\text { Assessment of source data. Performed } \\
\text { routinely by visiting data producing units, } \\
\text { cross-checking activities, and conducting data } \\
\text { trend analysis. Queries are submitted to data } \\
\text { producing units to review and revise the data. } \\
\text { Statistical techniques. Techniques for } \\
\text { derivation, aggregation, valuation, conversion } \\
\text { to domestic currency, preparation of bridge } \\
\text { tables, and estimation used for compilation of } \\
\text { GFS are sound. } \\
\text { Assessment and validation of intermediate } \\
\text { data and statistical outputs. Final data are } \\
\text { validated against budgetary and accounting } \\
\text { data sources. } \\
\text { Revision studies and analyses are conducted, } \\
\text { but not documented. }\end{array}$ & $\begin{array}{l}\text { Periodicity and timeliness for } \\
\text { GFS meet GDDS } \\
\text { recommendations. Data for the } \\
\text { consolidated nonfinancial public } \\
\text { sector and consolidated general } \\
\text { government are disseminated } \\
\text { monthly with a lag of six weeks, } \\
\text { foreign public debt data are } \\
\text { disseminated monthly with a lag } \\
\text { of one month, and domestic } \\
\text { public debt data are } \\
\text { disseminated weekly with a lag } \\
\text { of two days. } \\
\text { Consistency. Fiscal data are } \\
\text { consistent within the dataset and } \\
\text { reconcilable over a reasonable } \\
\text { period of time. Consistency with } \\
\text { monetary and balance of } \\
\text { payments statistics is assessed } \\
\text { regularly. Consistency between } \\
\text { GFS and national accounts is } \\
\text { not verified. } \\
\text { Revision policy and practice. } \\
\text { The revision schedule is } \\
\text { predetermined and reasonably } \\
\text { stable, but not made known to } \\
\text { the public. The first published } \\
\text { annual GFS data are } \\
\text { preliminary, and final data are } \\
\text { published after the data have } \\
\text { been revised. Data tables do not } \\
\text { include explanatory notes for } \\
\text { revisions made. Revision } \\
\text { studies and analysis of revisions } \\
\text { are not made public. }\end{array}$ & $\begin{array}{l}\text { There is room to improve } \\
\text { accessibility to the GFS in the } \\
\text { Statistical Bulletin and on the } \\
\text { MOF website, which could } \\
\text { facilitate proper interpretation } \\
\text { of the data and international } \\
\text { comparisons. Dissemination } \\
\text { media and format are adequate. } \\
\text { GFS are disseminated } \\
\text { according to a preannounced } \\
\text { schedule available on the CBB } \\
\text { website and the IMF's DSBB. } \\
\text { GFS are disseminated on the } \\
\text { MOF and CBB websites } \\
\text { simultaneously to all users. } \\
\text { Metadata accessibility. } \\
\text { Metadata is only available on } \\
\text { the IMF's DSBB. Metadata has } \\
\text { not been updated since } \\
\text { November } 2005 \text {. } \\
\text { Assistance to users is } \\
\text { provided via a contact e-mail } \\
\text { address posted in the MOF } \\
\text { publications and website. } \\
\text { Documents and other services, } \\
\text { including information on any } \\
\text { changes, are widely available. }\end{array}$ \\
\hline
\end{tabular}




\section{Methodological soundness}

Concepts and definitions. Monetary statistics follow the recommendations of the MFSM.

Scope. The depository corporations survey (DCS) covers the CBB, all commercial banks, credit unions, savings and loans associations, and the private financial funds. The accounts of banks in liquidation are included. The DCS does not cover seven Investment Funds Management Societies (SAFIs), which issue debit cards to their clients and account for around 6 percent of the ODC's liabilities included in broad money.

Classification/sectorization of financia instruments broadly follows the MFSM, with some exceptions. ODC data do not distinguish between other nonfinancial corporations and other resident sectors. Transactions with SAFIs are classified as transactions with OFCs rather than with

ODCs. There are problems of classification and application of residency criterion by some ODCs.

Basis for recording. Monetary statistics are produced on an accrual basis, which is consistent with the MFSM. Financial instruments are valued at market prices or amortized cost. Accounts in foreign currency are converted into national currency using the market exchange rate.

\section{Accuracy and reliability}

Source data. The DC survey is based on the consolidated balance sheets of the CBB and ODCs. The SBFE provides the $\mathrm{CBB}$ with daily balance sheets of the ODCs and a monthly report with a detailed sectorization of the accounts.

\section{Assessment of source data. The} Economic Policy Advisory Office (APEC) has electronic access to the accounting records of the CBB. Data for the ODCs are validated by the SBFE and electronically processed by the APEC.

\section{Statistical techniques. Sound} statistical techniques are used. The DCS is based strictly on the balance sheets of the CBB and the ODCs, and the supplementary monthly report with more detailed sectorization of the accounts of the ODCs.

\section{Assessment and validation of} intermediate data and statistical output. Monetary data are validated through the accounting identity: net foreign assets plus net domestic assets equal broad money. Interbank positions are automatically validated by the SBEF. Credit to the public sector is compared with debtor's data.

Revision studies. Analyses and studies of revisions are conducted and documented. The results of these studies are used to improve the statistical process.

\section{Serviceability}

Periodicity and timeliness meet GDDS recommendations and SDDS requirements.

Consistency. Monetary data are disseminated in consistent historical series. Discrepancies arise in the aggregated accounts of the ODCs because the SAFIs report claims on commercial banks for deposit certificates, which are reported as liabilities to the private sector (deposits) by commercial banks.

Monetary data are consistent with balance of payments and government finance data.

Revision policy and practice. The CBB does not have a regular revision schedule because data are disseminated as final and revisions are infrequent. Revisions studies are not disseminated, but revisions resulting from changes in methodology are documented in footnotes to the tables. Preliminary data are clearly identified.

\section{Accessibility}

Data accessibility. Data are presented in an aggregated form with methodological notes. The CBB publishes an advance release calendar. Data are posted on the CBB website and published in the CBB Monthly Bulletin. A government policy advisory committee is provided with data that may or may not have been disseminated to the public. However, this practice does not affect the pre-scheduled release.

Metadata accessibility. Bolivia has posted its monetary metadata on the IMF's DSBB since November 2000. The CBB website contains metadata and provides a hyperlink to the IMF's DSBB.

Assistance to users. Information on the contact person for monetary statistics is available on the CBB website and also on the IMF's DSBB. There is a catalog with CBB's publications, documents, and other services to users. 


\section{Methodological soundness \\ Concepts and definitions broadly} follow the BPM5 guidelines. Resident units are defined in conformity with BPM5.

Scope is broadly consistent with BPM5. However, data exclude: (1) unrecorded trade (contraband, shuttle trade, and illegal trade); (2) some government bonds issued locally and held by nonresidents; and (3) deposits of nonresidents in the financial sector.

\section{Classification/sectorization are}

broadly in line with BPM5 guidelines. However, more detailed breakdown is needed for the classification of several services. In addition, there are instrument misclassifications (e.g., trade credits are included in loans) and capital transfers are included in curren transfers. Most institutional units are attributed to the relevant sector according to the BPM5.

Basis for recording. In general, the principle of market valuation is used. However, flows derived from stocks of nonbank deposits abroad (assets) are not adjusted for exchange rate

changes. Recording is mostly done on an accrual basis in accordance with $B P M 5$, but interest on public sector external debt is recorded on a due-forpayment basis, and some dividends are recorded when paid rather than when declared payable.

\section{Accuracy and reliability}

Source data are broadly sufficient to compile statistics. Data sources include (1) CBB data; (2) administrative data from the NSI, the SBFE, and other government entities; (3) surveys; (4) direct reporting mainly by nonfinancial entities; and (5) data from foreign/international institutions.

Source data for certain services and financial transactions could be improved. Survey data for travel and foreign direct investment from the NSI have not been available since 200405 , respectively. Hence, the CBB initiated a Foreign Private Capital (FPC) survey in November 2006. The travel survey is expected to be resumed in 2007 .

Assessment of source data. Source data are routinely checked and analyzed to guide the statistical process.

Statistical techniques are used (some of which may need improvement) mainly to adjust trade data, estimate direct investment flows/stocks, and overcome insufficient coverage of services, workers' remittances, and private transfers. The CBB does not estimate unrecorded trade, including illegal activities.

\section{Assessment and validation of}

intermediate data and statistical output.

Statistical discrepancies are monitored. Data are validated against available

administrative data (including balance sheets) and other datasets.

Revision studies. Analysis of revisions informs statistical processes but they are not regularly documented.

\section{Serviceability}

Periodicity and timeliness of balance of payments data meet GDDS recommendations and SDDS requirements.

Consistency. Balance of payments data are broadly consistent internally and over time. However, errors and omissions are large in some years (an average of 4 percent of GDP during 1995-2005). Balance of payments and IIP data are reconciled quarterly. Data are largely consistent and/or reconcilable with merchandise trade, monetary, GFS, and external debt statistics. However, consistency with national accounts is not verified on a regular basis and may be affected by the lack of estimates of illegal trade, which are imputed in the national accounts.

\section{Revision policy and practice.} The revision cycle is predetermined and stable, but it is not publicized. Preliminary and revised data are identified. Analyses of data revisions are not disseminated.

\section{Accessibility}

Data accessibility. Data are disseminated in a format that follows BPM5 standard components. A wide range of data are readily available in different formats and detailed presentations. Time series are available on the $\mathrm{CBB}$ website. Data are released on a preannounced schedule and made available to all users simultaneously on the CBB website and in hardcopy publications.

\section{Metadata accessibility.}

Concepts, methodology, and data sources for the balance of payments are available on the CBB website and on the IMF's DSBB. In addition, the External Sector Bulletin includes a comprehensive sources and methods document.

Assistance to users is adequate The CBB website clearly identifies two contact points for balance of payments data. Contact information is also provided on the Fund's DSBB 


\section{STAFF's RECOMMENDATIONS}

Based on the review of Bolivia's statistical practices, discussions with the data producing agencies, and responses from data users, the mission presents a set of recommendations. They are designed to further increase adherence to internationally accepted statistical practices and would enhance the analytical usefulness of Bolivia's statistics. The recommendations are subdivided into "High priority" and "Other key recommendations." While all the high priority actions listed below should be treated as such, the cross-cutting recommendations need to be addressed with the greatest priority. More detailed technical suggestions are included in the Detailed Assessments volume for each dataset.

\section{Cross-cutting Recommendations}

\section{High Priority}

- Improve coordination among and within public institutions to facilitate information sharing and to avoid potential duplication in data collection and dissemination, as well as to improve intersectoral consistency.

- Ensure that agencies and units compiling macroeconomic statistics have adequate resources to undertake needed developmental work.

- Disseminate macroeconomics statistics simultaneously to all users, publicizing any prior access granted to selected users.

- Promote the adoption of the new Statistics Law and a National Statistical Plan.

- Strengthen data sources across all datasets, including surveys and censuses.

\section{Other key recommendations}

- Establish regular mechanisms to monitor the relevance of the statistics and to identify emerging data needs.

- Provide advance notice of changes in methodology, source data, and statistical techniques and disseminate advance release calendars, revision policies, and revision studies.

\section{National Accounts}

\section{High Priority}

- Formulate a comprehensive data collection program of economic censuses and surveys to support the compilation of the national accounts.

- Improve timeliness of national accounts to meet SDDS requirements.

- Give high priority to the ongoing project to update the national accounts' reference year and implement the $1993 \mathrm{SNA}$, and bring forward the targeted completion date.

- Improve the quality of the Volume and Producer Price Indices for manufacturing activities and improve the coverage and quality of volume measures for construction, commerce, and service activities.

- Assess the feasibility of using the households survey, and other sources, where available, to estimate the participation of the informal sector in GDP, and changes in employment and income generation. 


\section{Other key recommendations}

- Apply COFOG to the classification of government consumption expenditures.

- Assess feasibility of compiling directly the changes in inventories for important products.

\section{Consumer Price Index}

\section{High Priority}

- Update the CPI basket on the basis of results from the 2003/2004 HBS and the CPI Manual 2004.

\section{Other key recommendations}

- Improve treatment of seasonal products, missing items, quality changes, and introduction of new products.

- Calculate retroactive index series using chain linking between old a new series.

\section{Producer Price Index}

\section{High Priority}

- Adopt the 1993 SNA concepts and definitions, including new weights, changes in inventories, own-account production for final use, and the coverage of economic activities.

- Improve treatment of seasonal products, missing items, quality changes, and introduction of new products.

- Improve periodicity and timeliness to meet GDDS recommendations.

\section{Other key recommendations}

- Change the base year of the PPI, updating its weights by using output by industry and including all goods producing activities.

- Asses PPI data source and calculate the variance or sampling errors to guide the new PPI sample design.

- Calculate retroactive index series using chain linking, between old a new series.

\section{Government Finance Statistics}

\section{High priority}

- Ensure reporting of detailed data on the operations of all general government institutional units to the MOF.

- Compile and disseminate GFS for operations of the consolidated central government (including budgetary, extrabudgetary, and social security subsectors) and general government (including consolidated central government and regional and local government subsectors) following international best practices.

- Centralize the compilation of GFS to ensure intra-agency coordination, timely dissemination, and avoid overlapping responsibilities. 
- Integrate and standardize data sources for improving consistency of the GFS and for reducing the collection and compilation burden.

\section{Other key recommendations}

- Adopt a migration plan to the GFSM 2001.

- Improve presentation of GFS in hard copy and electronic publications.

\section{Monetary Statistics}

\section{High Priority}

- Expand the ODC survey with the inclusion of the accounts of the SAFIs.

- Reclassify accounts of SAFIs from OFCs to ODCs and separate the accounts of the private nonfinancial resident sector into accounts of "other nonfinancial corporations" (private enterprises) and "other resident sectors" (households and NPISHs).

\section{Other key recommendations}

- In collaboration with the SBFE, monitor that in the "sectoral accounts," ODCs are properly classifying accounts of nonresidents.

- Compile a monthly OFC survey, with data from insurance corporations, pension funds, NAFIBO, and FONDESIF.

- Facilitate staff access to Internet and telecommunications.

\section{Balance of Payments Statistics}

\section{High Priority}

- In consultation with the NSI, develop a methodology to include unrecorded trade and its counterpart transactions in the BOP.

- Provide additional staff resources to the BPD to undertake additional tasks associated with the recent introduction of the CBB's Foreign Private Capital (FPC) survey.

- Initiate in 2007 quarterly FPC surveys, identifying improvements in design, data validation, and sample techniques, based on the results of the 2006 FPC survey.

- Continue efforts to improve data collection and estimation techniques for workers' remittances and other transfers, and certain services and financial transactions.

\section{Other Key Recommendations}

- Resume in 2007 the semiannual travel survey, jointly conducted by NSI and CBB.

- Apply the accrual principle for recording interest on public sector external debt.

- Review external debt relief data recording to ensure that treatment is consistent with $B P M 5$, including the recording of debt forgiveness in the capital account.

- Compile and disseminate data on the external debt-service payment schedule (for total and public sector external debt), in line with the External Debt Guide. 
Appendix I. Bolivia: Practices Compared to the GDDS Coverage, Periodicity, and Timeliness of Data

\begin{tabular}{|c|c|c|c|c|c|}
\hline \multirow{2}{*}{ GDDS Data Category } & \multirow{2}{*}{$\begin{array}{c}\text { Coverage } \\
\text { (meets GDDS) }\end{array}$} & \multicolumn{2}{|c|}{ Periodicity } & \multicolumn{2}{|c|}{ Timeliness } \\
\hline & & GDDS & Bolivia & GDDS & Bolivia \\
\hline \multicolumn{6}{|c|}{ DATA CATEgORIES AND INDICATORS } \\
\hline \multicolumn{6}{|l|}{ Real Sector } \\
\hline $\begin{array}{l}\text { National accounts aggregates: } \\
\text { GDP (nominal and real) }\end{array}$ & Yes & $\mathrm{A}(Q)$ & Q & $6-9 \mathrm{M}$ & $3 \mathrm{M}$ \\
\hline $\begin{array}{l}\text { Gross national income, capital formation, } \\
\text { saving }\end{array}$ & Yes & $A$ & $A$ & $6-9 M$ & $11 \mathrm{M}$ \\
\hline $\begin{array}{l}\text { Production index/indices } \\
\text { Manufacturing or industrial indices }\end{array}$ & Yes & M & Q & $6 \mathrm{~W}$ & 2 \\
\hline $\begin{array}{l}\text { Primary commodity, agricultural, or other } \\
\text { indices, as relevant }\end{array}$ & Yes & As relevant & M & $3 \mathrm{M}$ & $6 \mathrm{~W}$ \\
\hline $\begin{array}{l}\text { Price indices: } \\
\text { Consumer price index }\end{array}$ & Yes & M & M & $1-2 \mathrm{M}$ & $1 \mathrm{D}$ \\
\hline Producer price index & Yes & $M$ & $Q$ & $1-2 M$ & $10 \mathrm{~W}$ \\
\hline $\begin{array}{l}\text { Labor market indicators: } \\
\text { Employment }\end{array}$ & Yes & $\mathrm{A}$ & $\begin{array}{c}\mathrm{Q} \text { (public) } \\
2 \mathrm{Q} \text { (private) }\end{array}$ & $6-9 \mathrm{M}$ & $\begin{array}{c}\mathrm{Q} \text { (public) } \\
4 \mathrm{M} \text { (private) }\end{array}$ \\
\hline Unemployment & Yes & A & A & $6-9 \mathrm{M}$ & $4 \mathrm{M}$ \\
\hline Wages/earnings (all sectors) & Yes & A & $\begin{array}{c}\mathrm{Q} \text { (public) } \\
2 \mathrm{Q} \text { (private) }\end{array}$ & $6-9 \mathrm{M}$ & $\begin{array}{c}\mathrm{Q} \text { (public) } \\
4 \mathrm{M} \text { (private) }\end{array}$ \\
\hline \multicolumn{6}{|l|}{ Fiscal Sector } \\
\hline $\begin{array}{l}\text { Central government aggregates: } \\
\text { Revenue, expenditure, balance, and financing } \\
\text { with breakdowns (debt holder, instrument, } \\
\text { currency), as relevant }\end{array}$ & No & Q & M & $1 \mathrm{Q}$ & $6 \mathrm{~W}$ \\
\hline Interest payments & Yes & $Q$ & $M$ & $1 Q$ & $6 W$ \\
\hline $\begin{array}{l}\text { Central government debt: } \\
\text { Domestic and foreign debt, as relevant, with } \\
\text { appropriate breakdowns (currency, maturity, } \\
\text { debt holder, instrument) }\end{array}$ & Yes & $\mathrm{A}(\mathrm{Q})$ & $\begin{array}{l}\mathrm{W} \text { (domestic) } \\
\mathrm{M} \text { (foreign) }\end{array}$ & $1-2 \mathrm{Q}$ & $\begin{array}{l}\text { 2D (domestic) } \\
1 \mathrm{M} \text { (foreign) }\end{array}$ \\
\hline Government guaranteed debt & Yes & $A(Q)$ & $M$ & $1-2 Q$ & $1 M$ \\
\hline
\end{tabular}

${ }^{1}$ Indexes for construction, telecommunications, electricity, transportation, hydrocarbons, and mining.

${ }^{2}$ While the index is compiled on a quarterly basis, it is only disseminated annually in the NSI's Statistical Yearbook. 


\begin{tabular}{|c|c|c|c|c|c|}
\hline \multirow{2}{*}{ GDDS Data Category } & \multirow{2}{*}{$\begin{array}{c}\text { Coverage } \\
\text { (meets GDDS) }\end{array}$} & \multicolumn{2}{|c|}{ Periodicity } & \multicolumn{2}{|c|}{ Timeliness } \\
\hline & & GDDS & Bolivia & GDDS & Bolivia \\
\hline \multicolumn{6}{|l|}{ Financial Sector } \\
\hline $\begin{array}{l}\text { Broad money and credit aggregates: } \\
\text { Net external position, domestic credit, broad or } \\
\text { narrow money }\end{array}$ & Yes & M & M & $1-3 \mathrm{M}$ & $3 \mathrm{~W}$ \\
\hline $\begin{array}{l}\text { Central bank aggregates: } \\
\text { Monetary base }\end{array}$ & Yes & M & $\mathrm{D}$ & $1-2 \mathrm{M}$ & $1 \mathrm{~W}$ \\
\hline $\begin{array}{l}\text { Interest rates: } \\
\text { Short- and long-term government. security } \\
\text { rates, policy variable rate } \\
\text { Money or interbank market rates and a range } \\
\text { of deposit and lending rates }\end{array}$ & Yes & $M$ & $W$ & 3 & $\begin{array}{l}1 \mathrm{~W} \\
1 \mathrm{~W}\end{array}$ \\
\hline $\begin{array}{l}\text { Stock market: } \\
\text { Share price index, as relevant }\end{array}$ & Not relevant & $M$ & $(\ldots)$ & 3 & $(\ldots)$ \\
\hline \multicolumn{6}{|l|}{ External Sector } \\
\hline $\begin{array}{l}\text { Balance of payments aggregates: } \\
\text { Imports and exports of goods and services, } \\
\text { current account balance, reserves, overall } \\
\text { balance. }\end{array}$ & Yes & $\mathrm{A}(Q)$ & Q & $6 \mathrm{M}$ & $7 \mathrm{~W}$ \\
\hline $\begin{array}{l}\text { External debt and service: } \\
\text { Public and publicly guaranteed external debt, } \\
\text { broken down by maturity }\end{array}$ & Yes & Q & M & $1-2 \mathrm{Q}$ & $1 \mathrm{M}$ \\
\hline $\begin{array}{l}\text { Public and publicly guaranteed debt service } \\
\text { schedule }\end{array}$ & Yes & Twice A & $(\ldots)$ & $3-6 \mathrm{M}$ & $(\ldots)$ \\
\hline $\begin{array}{l}\text { Private external debt not publicly guaranteed, } \\
\text { and debt service schedule }\end{array}$ & $\begin{array}{l}\text { Stock: Yes } \\
\text { Service } \\
\text { schedule: No }\end{array}$ & $A$ & $\begin{array}{l}\text { Stock: } Q \\
\text { Service } \\
\text { schedule: No }\end{array}$ & $6-9 M$ & $\begin{array}{l}\text { Stock: } 3 \mathrm{M} \\
\text { Service } \\
\text { schedule: No }\end{array}$ \\
\hline $\begin{array}{l}\text { International reserves: } \\
\text { Gross official reserves denominated in U.S. } \\
\text { dollars }\end{array}$ & Yes & M & M & $1-4 \mathrm{~W}$ & $4 \mathrm{~W}$ \\
\hline Reserve-related liabilities & Yes & $M$ & $M$ & $1-4 W$ & $4 W$ \\
\hline $\begin{array}{l}\text { Merchandise trade: } \\
\text { Total exports and total imports }\end{array}$ & Yes & M & M & $8 \mathrm{~W}-3 \mathrm{M}$ & $1 \mathrm{M}$ \\
\hline $\begin{array}{l}\text { Major commodity breakdowns with longer time } \\
\text { lapse }\end{array}$ & Yes & $M$ & $M$ & $8 W-3 M$ & $1 M$ \\
\hline $\begin{array}{l}\text { Exchange rates: } \\
\text { Spot rates }\end{array}$ & Yes & $\mathrm{D}$ & $\mathrm{D}$ & 3 & Same day \\
\hline \multicolumn{6}{|c|}{$\begin{array}{l}\mathrm{D}=\mathrm{Daily} ; \mathrm{W}=\mathrm{Week}(\mathrm{ly}) ; \mathrm{WD}=\text { Working days; } \mathrm{M}=\operatorname{Month}(\mathrm{ly}) ; \mathrm{Q}=\mathrm{Quarter}(\mathrm{ly}) ; \mathrm{A}=\text { Annually; NLT }=\text { No later than; }(\ldots)=\text { not } \\
\text { applicable } \\
\text { Italics indicate encouraged categories. }\end{array}$} \\
\hline
\end{tabular}

${ }^{3}$ Dissemination as part of a high-frequency (e.g. monthly) publication.

${ }^{4}$ Data are compiled but not disseminated. 
INTERNATIONAL MONETARY FUND

BOLIVIA

\section{Report on the Observance of Standards and Codes (ROSC)—Data Module}

\section{Response by the Authorities}

August 2, 2007

\section{Contents}

I. Introduction . .2

II. Response to the Mission's Assessment and Recommendations

$\frac{.2}{\frac{2}{2}}$

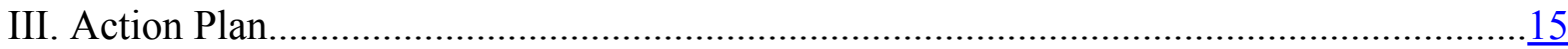

A. Cross-cutting Actions..................................................................................

B. National Accounts Statistics........................................................................17

C. Consumer Price Index ………………………….......................................19

D. Producer Price Index ...................................................................................

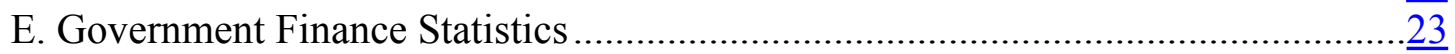

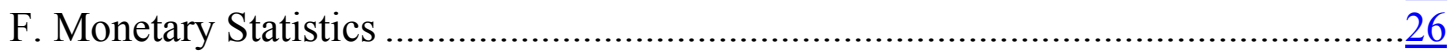

G. Balance of Payments Statistics ………………………....................................... 


\section{INTRODUCTION}

1. We appreciate the opportunity to provide comments on the ROSC data module. We collaborated closely with the data module ROSC mission and agree with the thrust of the mission's recommendations. Below are comments from the Central Bank of Bolivia (CBB), the Ministry of Finance (MOF), and the National Statistical Institute (NSI) on the five datasets assessed during the mission.

\section{RESPONSE TO THE MisSion's ASSESSMENT AND RECOMMENDATIONS}

\section{A. National Accounts Statistics}

2. Section B in Part III of this document presents a detailed action plan to adopt the recommendations of the ROSC mission in the area of national accounts.

\section{B. Price Statistics}

3. Sections C and D in Part III of this document present a detailed action plan to adopt the recommendations of the ROSC mission in the area of price statistics.

\section{Government Finance Statistics}

4. The ROSC document was reviewed by the Fiscal Programming Unit (UPF) of the Ministry of Finance (MOF), which focused on the detailed assessment using the DQAF. Comments and responses to the mission's recommendations are summarized below.

\section{Indicator $0.1 .1^{1}$}

\section{Mission's recommendation}

Improve coordination between the two units of the MOF that share the responsibility of GFS compilation, to achieve comprehensive collection, compilation, and dissemination of GFS.

\section{Comment}

The UPF has as an institutional mission the design and follow-up of the fiscal program, providing the authorities with reliable and timely data for decision making. Additionally, the UPF provides the general public with fiscal statistics compiled on the basis of cashflows of the agencies under its aegis. On the other hand, the Accountant General of the Republic is responsible for the production of the financial statements of the public sector, receiving the balance sheets of the public agencies three months after the end of the fiscal

\footnotetext{
${ }^{1}$ The numbers refer to the relevant section in the document Bolivia: Report on the Observance of Standards and Codes (ROSC)—Data Module.
} 
year. Additionally, we are in the process of coordinating between several units within the MOF and other agencies, with a view to implementing the GFSM 2001 and the Public Expenditure and Financial Accountability methodology.

\section{Indicator 0.3.1}

\section{Mission's recommendation}

Make more systematic efforts to identify new and emerging data requirements and undertake surveys to obtain feedback about the relevance and practical utility of fiscal data.

\section{Comment}

The UPF is in constant contact with users of GFS, which transmit - either verbally or in writing - to the UPF their requirements and comments. These comments are taken into account when producing information for the general public.

\section{Indicator 1.2.2}

\section{Mission's statement}

No official agency outside of the MOF has access to data prior to publication. Procedures for authorizing dissemination of GFS, deemed to be internal, are made public only in a limited manner. The minister or vice-minister of the MOF authorizes the release of GFS.

\section{Comment}

The UPF disagrees with this statement. The process of compiling GFS finalizes with their submission to the Minister of Finance and their immediate dissemination to the general public.

\section{Indicator 1.2.3}

\section{Mission's recommendation}

Clearly identify data sources and the entity in charge of data compilation in all statistical products.

\section{Comment}

This recommendation will be taken into account in the upcoming issues of the Dossier Estadístico and the Boletín de Recursos HIPC II, as well as on the MOF webpage. 


\section{Indicator 1.2.4}

\section{Mission's recommendation}

Provide advance notice of all methodological and other relevant changes that materially affect the GFS.

\section{Comment}

The revisions will be detailed in footnotes to the published tables in the upcoming issues of the Dossier Estadístico and the Boletín de Recursos HIPC II, as well as on the MOF webpage.

\section{Indicator 2.2.1}

\section{Mission's recommendation}

Expand the scope of institutions and transactions in the GFS to include comprehensive and detailed data of the operations of some decentralized agencies and local governments, and make special efforts to compile debt data of local governments.

\section{Comment}

We want to stress that the current coverage encompasses the transactions of the financial accounts of all municipalities. Those beyond the coverage of the UPF are estimated on the basis of the monthly transactions of their financial accounts. We are also in the process of including cash flows of provincial municipalities, although their geographical location hinders this task. Furthermore, we process debt data of the largest municipalities and have created a Performance Program to capture data of local governments.

\section{Indicator 2.3.1}

\section{Mission's statement}

Contrary to recommendations in the manuals, the GFS compiled by the UPF have the following shortcomings: (1) statistics on the consolidated central government are not prepared; and (2) statistics on the social security sector do not include detailed data of the Corporation of Military Social Insurance.

\section{Comment}

The Ministry of Finance, within the framework of harmonization of the GFS of the region, is considering adopting definitions consistent with GFS manuals. 


\section{Mission's recommendation}

- Reclassify royalties as other revenue item; commissions for interest as goods and services item; tax refunds as a revenue item; social assistance benefits as transfers to households; repayments as an expense item and present a net item, lending minus repayments; and payments for pensions as compensation of employee item.

- Reclassify as other capital revenue two categories wrongly classified as current revenue, "other capital revenue" and the part corresponding to capital revenue in "other revenues".

- Collect and compile disaggregated data for some items included in expenses, such as "universities" and "others", to obtain an adequate economic classification.

- Classify tax revenues, financing, and debt by instrument, holder and maturity following the recommendations of the GFS manuals.

\section{Comment}

We are evaluating to introduce changes in the data presentation, according to the mission's recommendations.

\section{Indicator 2.4.3}

\section{Mission's recommendation}

Include tax refunds in the taxes, netting from the corresponding tax, if possible; while lending minus repayment should be included as an expenditure category (when using the GFSM 1986 methodology).

\section{Comment}

We are evaluating to introduce changes in the data presentation, according to the mission's recommendations.

\section{Indicator 3.1.1}

\section{Mission's statement}

The main data sources for the first stage are diverse; they include administrative systems for monitoring the budget execution and accounting. These systems are: the SIGMA, the SINCON, and some integrated systems of public units. In addition to these systems, the UPF has developed a system to collect timely data that are not available through the systems previously mentioned. Among these systems, there are no interfaces to reconcile data and guarantee consistency. Also, since these systems are not integrated, a duplication of collection and compilation efforts has emerged. 


\section{Comment}

The integrated systems SIGMA and SINCON are not used by all agencies of the nonfinancial public sector. Furthermore, these systems very often do not have updated information. When such contingencies occur, the UPF used the Monthly Flow Registry to process the cash flow - mainly in municipalities and some other agencies - as a versatile and timely system that allows to have available cash based data, which is reconciled with bank statements of each agency, and therefore is highly reliable.

\section{Indicator 5.1.1}

\section{Mission's statement}

Although the disseminated GFS permit identification and comparison of major aggregates of flows, there is room for improvement. For example, data sources and units in charge of data production should be noted; titles of the tables should be harmonized and revised; texts with analysis of the data published could be included; several acronyms should be spelled out or a list of acronyms should be included at the beginning of the publications; and stock data, such as domestic and external debt by sector, should be included.

\section{Comment}

Our comment on indicator 1.2.3 already tackled the issue of data sources. With respect to other recommendations, they are being considered for the next issue of Dossier Estadístico, Vol. IX, the Boletín de Recursos HIPC II, and the MOF webpage.

\section{Indicator 5.1.3}

\section{Mission's recommendation}

Post the preannounced calendar for dissemination of GFS on the MOF website.

\section{Comment}

The advance release calendar for the fiscal year 2007 has already been posted on the UPF website.

\section{Indicator 5.3.1}

\section{Mission's statement}

Material to raise awareness on the use of statistics is available, but assistance to users is not monitored. 


\section{Comment}

Assistance to users is provided, either personally or via electronic mail, and it is monitored and assessed by the relevant staff.

\section{Monetary Statistics}

5. The ROSC document was reviewed by the Monetary and Fiscal Sector Deputy Management Office (SSMF) of the Central Bank of Bolivia, which focused on the detailed assessment using the DQAF. Comments and responses to the mission's recommendations are summarized below.

\section{Indicator 0.2.1}

\section{Mission's recommendation}

Revise the internal CBB policy on access to the Internet and use of telephone for external calls.

\section{Comment}

Unlimited internet access has already been authorized to compilers of monetary statistics. The remainder of the logistical support is in the process of being implemented.

\section{Indicator 0.3.1}

\section{Mission's statement}

The CBB does not have a policy of periodically consulting users of monetary statistic about their needs.

\section{Comment}

The CBB has posted on its website, and will include in its hardcopy publications, a form to request comments and suggestions on the statistics it publishes.

\section{Indicator 1.2.2}

\section{Mission's statement}

The latest monetary data, together with other macroeconomic data, are provided regularly to the Macroeconomic Group, an economic policy analysis committee. Depending on the scheduled release calendar, the Macroeconomic Group may or may not have access to the statistics prior to its public dissemination. However, this earlier access does not interfere with the scheduled release of the data. On its website, the CBB acknowledges this possibility of selected access prior to release. 


\section{Comment}

The data available to the Macroeconomic Group prior to its publication are tables for the Monetary and Financial Program, which are used for economic policy decision making. This Group does not discuss nor review the monetary and financial statistics to be published by the CBB.

This information is produced according to a methodology agreed in a Memorandum of Understanding signed between the Ministry of Finance and the CBB. The basic information shows the performance compliance of certain monetary and fiscal variables (for instance, fiscal deficit, internal and external financing, net domestic credit to the nonfinancial public sector, net domestic credit, international reserves). These variables are subjected to some adjustments agreed to monitor the compliance of monetary and fiscal targets, and furthermore are presented to the Macroeconomic Group using a fixed exchange rate for the U.S. dollar, the SDR, and the Housing Promotion Unit (UFV); a methodology that differs from the one used when constructing the monetary tables disseminated to the public. The CBB Annual Memory and the bi-annual Monetary Policy Report contain some marginal references to these variables.

In summary, neither in the content of the information submitted to the Macroeconomic Group, nor in its spirit, one can say that there is a clear and direct relationship with the figures published by the CBB, or that these figures could be used to derive nonpublished data. We must also stress that the meetings of the Macroeconomic Group do not deal with the quality of the data provided by the CBB.

In this sense, there is no previous knowledge by the authorities of the content of upcoming publications of the $\mathrm{CBB}$, nor any influence on them by the Macroeconomic Group, because the monetary and financial statistics disseminated on a weekly basis are not provided to the Macroeconomic Group. Furthermore, the data provided to the Macroeconomic Group is a small fraction of the information available on the CBB website and its hardcopy publications. Therefore, we dismiss the possibility that there is earlier governmental access to monetary and financial statistics, or any influence on them.

\section{Indicator 1.2.4}

\section{Mission's recommendation}

Give advance notice to the users of the upcoming expansion of the coverage of the ODC survey, the compilation of an OFC survey, and any other major methodological revision.

\section{Comment}

Immediately, any change in methodology, source data, or statistical techniques will be previously informed on the CBB webpage. 


\section{Indicator 2.2.1}

\section{Mission's recommendation}

Expand the coverage of the ODC survey, to include the accounts of the SAFIs.

\section{Comment}

Action already taken to expand the coverage of the ODC survey. It is foreseen that the September 2007 issue of the monthly bulletin will include the accounts of the SAFIs in the ODC survey.

\section{Mission's recommendation}

Start compiling a monthly OFC survey, with data from pension funds, insurance corporations, and the one state-owned financial corporation, Development Productive Bank. To automate the process, the Systems Management Office developed a computing routine to aggregate the data of the two pension funds.

\section{Comment}

The SSMF has already a program that permits the compilation of the pension funds data in the format requested by the mission, and the September 2007 issue of the monthly bulletin will include information on pension funds. For the accounts of insurance corporations, the Systems Management Office of the CBB developed a program to permit the data consolidation. However, the Superintendency of Pensions, Securities, and Insurances is facing staff shortages, which hamper the electronic transfer to the CBB of data from 2002 onwards.

\section{Indicator 2.3.1}

\section{Mission's statement}

Accounts of the SAFIs are classified as Other Financial Corporations rather than as Other Depository Corporations.

\section{Comment}

On October 24, 2006, the CBB asked the Superintendency of Banks and Financial Entities to create sector A39 Investment Fund Management Societies, separating them from A38 Other Financial Corporations. This new classification was implemented starting with the report of January 2007. Regarding the inclusion of the SAFIs in the ODC sector, its implementation is taking place in two stages. The first one requires the manual uploading of the data for the years 2002 to 2006. For the second stage (year 2007 onwards), the module with the new chart of accounts has already been prepared and we are discussing with the Superintendency of Pensions, Securities, and Insurances the electronic transmission of data according to the new chart of accounts. 


\section{Mission's statement}

There is not a breakdown between other nonfinancial corporations and other resident sectors.

\section{Comment}

On October 24, 2006, the CBB asked the Superintendency of Banks and Financial Entities to split account A50 Private nonfinancial sector into A51 Other nonfinancial corporations and A52 Other resident sectors, classification that has been implemented starting with the reporting for January 2007.

\section{Mission's recommendation}

In collaboration with the SBFE, undertake efforts to eliminate the detected mistakes in the sectorization of the accounts of ODCs.

\section{Comment}

On February 26, 2007, the SSMF provided the Superintendency of Banks and Financial Entities with a detailed report of all the misclassifications detected in the data reported by ODCs. The Superintendency took the corresponding actions. On April 18, 2007 a new review was undertaken with the data reported for March 2007. The whole entities show too much interest to report their information with better quality.

\section{Indicator 3.2.1}

\section{Mission's recommendation}

Develop a routine that automatically flags significant changes in the balances of selected accounts, or balances that do not correspond with the expected values.

\section{Comment}

Under consideration. The routine could be generated by a database currently under construction.

\section{Indicator 4.3.3}

\section{Mission's statement}

Studies and analyses of revisions are not made public. 


\section{Comment}

The September 2007 issue of the monthly bulletin will include a methodological annex of all published tables. Such annex is being currently developed and will allow implementing this recommendation. Likewise, this recommendation will be fully adopted when the plans described in item 1.2.4 are implemented.

\section{Indicator 5.1.4}

\section{Mission's statement}

Monetary data may be made available to the Macroeconomic Group prior to their public dissemination, but this early access does not interfere with the scheduled release calendar.

\section{Comment}

This statement is not pertinent. For the authorities' response, see item 1.2.2. Therefore, the rating of indicator 5.1 should be upgraded from $\mathrm{LO}$ to $\mathrm{O}$.

\section{E. Balance of Payments Statistics}

6. The ROSC document was reviewed by the External Sector Deputy Management Office (SSE) of the Central Bank of Bolivia, which focused on the detailed assessment using the DQAF. Comments and responses to the mission's recommendations are summarized below.

\section{Indicator 0.1.1}

\section{Comment}

The report should include a reference to Article 20 of the CBB law, which constitutes the legal framework backing the data requirements to the private sector for balance of payments statistics mentioned in indicator 0.1.4.

\section{Indicator 0.3.1}

\section{Mission's statement}

Establish regular procedures to obtain user's feedback on the relevance of BOP statistics and emerging data needs (preferably through users' surveys).

\section{Comment}

The BCB has already established this procedures. For example, there exists a questionnaire on the subject in the CBB`s website. 


\section{Indicator 1.2.2}

The Macroeconomic Group that meets periodically to monitor the macroeconomic and financial developments receives the latest available monetary and financial information that may or may not have been published on the CBB website. This practice may generate in some cases internal government access prior to their dissemination to the public, but with no interference with their pre-scheduled public dissemination. This practice is publicly identified in the $\mathrm{CBB}$ metadata posted on the $\mathrm{CBB}$ website.

\section{Comment}

Any reference to earlier government access to macroeconomic statistics should be deleted, because this is not the case for balance of payments.

\section{Indicator 2.2.1}

\section{Mission's recommendation}

Assess the extent to which nonresident's deposit could be identified from total bank deposits in SBFE data.

\section{Comment}

This recommendation should be implemented in coordination with the SSMF

\section{Indicator 2.3.1}

\section{Mission's recommendation}

Align the classification of transactions in services and transfers, and the sectorization of institutional units with the BPM5 guidelines.

\section{Comment}

The alignment of the sectorization of institutional units with the BPM5 corresponds only to external debt transactions in the balance of payments and the international investment position.

\section{Mission's recommendation}

Review the external debt relief data recording in line with the BPM5, including the recording of debt forgiveness in the capital account.

\section{Comment}

This recommendation is superfluous because the debt relief is recorded in the balance of payments as a capital transfer, with a corresponding contra-entry in the financial account. This can be verified in the following publications: (1) Balance of Payments and 
International Investment Position Report, January-December 2006, page 7; and (2) Monthly Bulletin, № 145, January 2007, Table 24. Both publications are available on the CBB website and show on an aggregated basis the debt relief under the MDRI: World Bank (US\$ 1,511.3 million) and IMF (US\$ 232.5 million); and under the HIPC: Japan (US\$ 63 million); for a total of US\$1,806.8 million.

\section{Mission's recommendation}

Align the classification and coverage of the reserves template to the IMF guidelines.

\section{Comment}

Some of the recommendations regarding the reserves template have been already implemented by the CBB during the data ROSC mission. Guidance on the recording of capital contributions to the FLAR in the reserves template was provided after the mission in a letter from the STA's Balance of Payments and External Debt Division II to the CBB's SEE on March 5, 2007.

\section{Mission's recommendation}

Exclude the RAL Fund (US\$ 489.9 million) from Section I. B Other foreign currency assets and from Section III 1.B Other contingent liabilities.

\section{Comment}

This issue was already solved during the stay of the mission. This can be verified in Table 30 (International Reserves and Foreign Currency Liquidity Template) of the monthly bulletin ( $\mathrm{N}^{\mathrm{o}}$ 135, January 2007), posted on the CBB website.

\section{Mission's recommendation}

Include all short-term foreign-currency deposits of the financial sector with the CBB as predetermined short-term net drains on foreign currency assets in Section II.1 Outflows.

\section{Comment}

The recommendation is currently not applicable. Short-term foreign currency deposits of the financial sector with the $\mathrm{CBB}$ constitute part of the legal reserve requirements.

\section{Mission's recommendation}

Exclude from Section II.3 Other trade credit $(+)$ the positive balances with ALADI's Agreement of Reciprocal Payments and Credit to avoid double counting with Section I.A.5. 


\section{Comment}

This issue was already solved during the stay of the mission. This can be verified in Table 30 (International Reserves and Foreign Currency Liquidity Template) of the monthly bulletin ( $\mathrm{N}^{\mathrm{o}} 135$, January 2007), posted on the CBB website.

\section{Mission's recommendation}

When applicable, include the negative balances with ALADI's Agreement of Reciprocal Payments and Credit as predetermined short-term net drains on foreign currency assets in Section II.3 Other trade credit (-)

\section{Comment}

This issue was already solved during the stay of the mission. This can be verified in Table 30 (International Reserves and Foreign Currency Liquidity Template) of the monthly bulletin ( $\mathrm{N}^{\mathrm{o}}$ 135, January 2007), posted on the CBB website.

\section{Mission's recommendation}

When applicable, include in Section IV. 1 b) [of the Reserves Template] short-term domestic-currency debt indexed to foreign exchange rates and short-term financial instruments denominated in foreign currency but settled in domestic currency.

\section{Comment}

The recommendation is currently not applicable. At present, there are no securities indexed to the U.S. dollar (value maintenance) in circulation. If in the future operations in this kind of instrument take place, they will be included in the Reserves Template.

\section{Mission's recommendation}

The currency composition of official reserve assets disclosed in Section IV.2 a), according to those currencies in the SDR basket and those not in the SDR basket, should match the amounts reported in Section I.A.

\section{Comment}

This issue was already solved during the stay of the mission. This can be verified in Table 30 (International Reserves and Foreign Currency Liquidity Template) of the monthly bulletin ( $\mathrm{N}^{\mathrm{o}} 135$, January 2007), posted on the CBB website.

\section{Mission's recommendation}

Official reserve assets in gold should be reclassified from assets in currency not in the SDR basket to assets in currencies in the SDR basket within Section IV.2 a). 


\section{Comment}

This issue was already solved during the stay of the mission. This can be verified in Table 30 (International Reserves and Foreign Currency Liquidity Template) of the monthly bulletin ( $\mathrm{N}^{\mathrm{o}} 135$, January 2007), posted on the CBB website.

\section{Indicator 3.1.3}

\section{Mission's recommendation}

Employ more rigorous procedures to ensure the timely receipt of respondents' data.

\section{Comment}

This recommendation should refer only to service, remittances, and foreign private capital.

\section{Indicator 3.3.1}

Mission's recommendation

Review statistical techniques to adjust data for missing observations.

\section{Comment}

This recommendation should refer only to service, remittances, and foreign private capital.

\section{Indicator 4.2.3}

\section{Mission's recommendation}

Prepare and disseminate a table on quarterly reserve assets reconciliation between monetary and BOP statistics.

\section{Comment}

This recommendation should be done in coordination with SSMF.

\section{ACtion Plan}

7. Based on the ROSC's recommendations, and in collaboration with the mission, we have designed an action plan to further increase the analytical usefulness of Bolivia's statistics. This plan will be very useful to guide the future work in the national compiling agencies and also to guide the work of international organizations and donors in the statistics field. In particular, we count with the support of the IMF - among other international organizations and donor countries - to carry out the proposed actions. 
8. A detailed action plan is presented in the attached tables, which include crosscutting actions as well as measures specific to each data set. It should be noted that not all actions included in this plan have the same importance or priority, and that at times they are conditional upon the reassignment of resources, funding, training, or technical assistance.

\section{A. Cross-cutting Actions}

\section{High Priority Actions}

- Improve coordination among and within public institutions to facilitate information sharing and to avoid potential duplication in data collection and dissemination, as well as to improve intersectoral consistency.

- Ensure that agencies and units compiling macroeconomic statistics have adequate resources to undertake needed developmental work.

- Disseminate macroeconomics statistics simultaneously to all users, publicizing any prior access granted to selected users.

- Promote the adoption of the new Statistics Law and a National Statistical Plan.

- Strengthen data sources across all datasets, including surveys and censuses.

\section{Other Key Actions}

- Establish regular mechanisms to monitor the relevance of the statistics and to identify emerging data needs.

- Provide advance notice of changes in methodology, source data, and statistical techniques and disseminate advance release calendars, revision policies, and revision studies. 


\begin{tabular}{|c|c|c|}
\hline $\begin{array}{l}\text { DQAF } \\
\text { Code }\end{array}$ & Planned Actions & Timing \\
\hline \multicolumn{3}{|c|}{ Prerequisite of Quality } \\
\hline 0.1 .1 & - Give high priority to the approval of the new Statistical Law. & $\begin{array}{l}\text { Short } \\
\text { term }\end{array}$ \\
\hline 0.1 .2 & $\begin{array}{l}\text { - Take actions to improve data sharing and coordination } \\
\text { relations with the CBB and the MOF. }\end{array}$ & $\begin{array}{l}\text { Short } \\
\text { term }\end{array}$ \\
\hline 0.2 .1 & $\begin{array}{l}\text { - Provide the resources required to establish an adequate data } \\
\text { collection program for national accounts. }\end{array}$ & $\begin{array}{l}\text { Short } \\
\text { term }\end{array}$ \\
\hline 0.3 .1 & $\begin{array}{l}\text { - Establish a mechanism to contact users and identify their } \\
\text { opinion on the usefulness of the national accounts and their } \\
\text { new and emerging data requirements. }\end{array}$ & $\begin{array}{l}\text { Medium } \\
\text { term }\end{array}$ \\
\hline \multicolumn{3}{|c|}{ Methodological Soundness } \\
\hline 2.2 .1 & $\begin{array}{l}\text { - Give high priority to the ongoing project to update the national } \\
\text { accounts' reference year and implement the } 1993 S N A \text {, and } \\
\text { bring forward the targeted completion date. }\end{array}$ & $\begin{array}{l}\text { Short } \\
\text { term }\end{array}$ \\
\hline 2.2 .1 & - Apply COFOG to classify the government's expenses. & $\begin{array}{c}\text { Medium } \\
\text { term }\end{array}$ \\
\hline \multicolumn{3}{|c|}{ Accuracy and Reliability } \\
\hline 3.1 .1 & - Update the establishment /enterprise directory. & $\begin{array}{l}\text { Short } \\
\text { term }\end{array}$ \\
\hline 3.1 .1 & $\begin{array}{l}\text { - Formulate a program of economic annual and quarterly } \\
\text { surveys, to support the regular compilation of national } \\
\text { accounts. }\end{array}$ & $\begin{array}{l}\text { Short } \\
\text { term }\end{array}$ \\
\hline 3.1 .1 & $\begin{array}{l}\text { - Improve the quality of volume and price indices for } \\
\text { manufacturing activities. }\end{array}$ & $\begin{array}{l}\text { Short } \\
\text { term }\end{array}$ \\
\hline 3.1 .2 & $\begin{array}{l}\text { - Uniform the use of ISIC rev.3 by different source data } \\
\text { applying an economic activity classification. }\end{array}$ & $\begin{array}{l}\text { Short } \\
\text { term }\end{array}$ \\
\hline 3.2 .1 & $\begin{array}{l}\text { - On the basis of updated establishments/ enterprises directories } \\
\text { apply scientific sampling methods in } \\
\text { establishments/enterprises surveys. }\end{array}$ & $\begin{array}{l}\text { Medium } \\
\text { term }\end{array}$ \\
\hline 3.3 .1 & $\begin{array}{l}\text { - Assess the possibility of using the households survey, and } \\
\text { other sources, whereas available, to estimate the participation } \\
\text { of the informal sector, and changes through time, in } \\
\text { employment and income generation. }\end{array}$ & $\begin{array}{l}\text { Short } \\
\text { term }\end{array}$ \\
\hline
\end{tabular}




\begin{tabular}{|c|c|c|}
\hline 3.3 .2 & $\begin{array}{l}\text { - Define fixed cells in the S\&U table where available data } \\
\text { permits. }\end{array}$ & $\begin{array}{l}\text { Short } \\
\text { term }\end{array}$ \\
\hline 3.3 .2 & $\begin{array}{l}\text { - Apply the recommended 1993SNA treatment of pension } \\
\text { funds. }\end{array}$ & $\begin{array}{l}\text { Short } \\
\text { term }\end{array}$ \\
\hline 3.3 .2 & - Apply a better method to estimate FISIM at constant prices. & $\begin{array}{l}\text { Short } \\
\text { term }\end{array}$ \\
\hline 3.5 .1 & - Carry out routinely studies of revisions. & $\begin{array}{l}\text { Short } \\
\text { term }\end{array}$ \\
\hline \multicolumn{3}{|c|}{ Serviceability } \\
\hline 4.2 .3 & $\begin{array}{l}\text { - Prepare and disseminate bridge table, showing how to } \\
\text { reconcile the national accounts with BOP and GFS figures. }\end{array}$ & $\begin{array}{l}\text { Short } \\
\text { term }\end{array}$ \\
\hline 4.3 .1 & $\begin{array}{l}\text { Disseminate a schedule for the revision cycle of the national } \\
\text { accounts and explain reasons for its adoption. }\end{array}$ & $\begin{array}{l}\text { Short } \\
\text { term }\end{array}$ \\
\hline 4.3 .2 & $\begin{array}{l}\text { - Identify revised data in the publications and explain the } \\
\text { reasons for revisions. }\end{array}$ & $\begin{array}{l}\text { Short } \\
\text { term }\end{array}$ \\
\hline \multicolumn{3}{|c|}{ Accessibility } \\
\hline 5.1 .4 & $\begin{array}{l}\text { - Inform the public on the access of the government to data, } \\
\text { prior to their dissemination to the public. }\end{array}$ & $\begin{array}{l}\text { Short } \\
\text { term }\end{array}$ \\
\hline 5.1 .5 & $\begin{array}{l}\text { - Make the public aware on the availability of additional } \\
\text { statistics, and of the procedures for obtaining them. }\end{array}$ & $\begin{array}{c}\text { Short } \\
\text { term }\end{array}$ \\
\hline
\end{tabular}


C. Consumer Price Index

\begin{tabular}{|c|c|c|}
\hline $\begin{array}{l}\text { DQAF } \\
\text { Code }\end{array}$ & Planned Actions & Timing \\
\hline \multicolumn{3}{|c|}{ Prerequisite of Quality } \\
\hline 0.2 .1 & - Financing will be needed to improve the quality of the CPI. & $\begin{array}{l}\text { Short } \\
\text { term }\end{array}$ \\
\hline 0.3 .1 & $\begin{array}{l}\text { - Establish regular mechanisms to consult data users to monitor the } \\
\text { relevance of the statistics and to identify their information needs. }\end{array}$ & $\begin{array}{l}\text { Short } \\
\text { term }\end{array}$ \\
\hline 0.4 .2 & $\begin{array}{l}\text { Prepare monthly reports to inform management of the quality of } \\
\text { surveys' data (surveys' response rate, coverage, response errors, } \\
\text { etc.). }\end{array}$ & $\begin{array}{l}\text { Short } \\
\text { term }\end{array}$ \\
\hline \multicolumn{3}{|c|}{ Methodological Soundness } \\
\hline 2.1 .1 & $\begin{array}{l}\text { - Adopt the recommendations of the } 1993 \text { SNA and CPI Manual } \\
2004 \text {. }\end{array}$ & $\begin{array}{l}\text { Short } \\
\text { term }\end{array}$ \\
\hline 2.3 .1 & $\begin{array}{l}\text { - Define the basket of a new CPI using systems broadly consistent } \\
\text { with internationally accepted standards, in accordance with } \\
\text { - } 1993 \text { SNA } \\
\text { - Classification of Individual Consumption by Purpose } \\
\text { (COICOP) }\end{array}$ & $\begin{array}{l}\text { Short } \\
\text { term }\end{array}$ \\
\hline \multicolumn{3}{|c|}{ Accuracy and Reliability } \\
\hline 3.2 .1 & $\begin{array}{l}\text { - Improvement the efficiency of sampling techniques trough asses } \\
\text { CPI data source to prices surveys. }\end{array}$ & $\begin{array}{l}\text { Short } \\
\text { term }\end{array}$ \\
\hline 3.2 .1 & $\begin{array}{l}\text { - Asses CPI data source and calculate response rate, coverage, } \\
\text { response errors, etc. }\end{array}$ & $\begin{array}{l}\text { Short } \\
\text { term }\end{array}$ \\
\hline 3.3 .1 & $\begin{array}{l}\text { - Employ better statistical techniques to improve treatment of } \\
\text { seasonal products, missing items, quality changes, and } \\
\text { introduction of new products. }\end{array}$ & $\begin{array}{l}\text { Short } \\
\text { term }\end{array}$ \\
\hline 3.3 .2 & $\begin{array}{l}\text { - Adopt the following } 1993 \text { SNA and the new CPI Manual, } 2004 \\
\text { recommendations: } \\
\text { - Include Imputed Rentals of owner-occupied dwellings in the } \\
\text { CPI weights. } \\
\text { - Use of the geometric mean for price changes. } \\
\text { - Calculate retroactive index series using chain linking, between } \\
\text { old a new series. }\end{array}$ & $\begin{array}{l}\text { Short } \\
\text { term }\end{array}$ \\
\hline 3.5 .1 & $\begin{array}{l}\text { - Update of the new basket of the index, and conduction of studies } \\
\text { about the difference between the both new and old CPI. }\end{array}$ & $\begin{array}{l}\text { Short } \\
\text { term }\end{array}$ \\
\hline
\end{tabular}




\begin{tabular}{|c|c|c|c|}
\hline \multicolumn{3}{|c|}{ Serviceability } \\
\hline 4.3 .3 & $\begin{array}{l}\text { Document of the comparative studies between the new and the } \\
\text { old CPI. }\end{array}$ & $\begin{array}{c}\text { Short } \\
\text { term }\end{array}$ \\
\hline \multicolumn{3}{|c|}{ Accessibility } \\
\hline 5.1 .3$. & $-\begin{array}{l}\text { Disseminate a preannounced schedule with the dates the statistics } \\
\text { are to be released. }\end{array}$ & $\begin{array}{l}\text { Short } \\
\text { term }\end{array}$ \\
\hline
\end{tabular}


D. Producer Price Index

\begin{tabular}{|c|c|c|}
\hline $\begin{array}{c}\text { DQAF } \\
\text { Code }\end{array}$ & Planned Actions & Timing \\
\hline \multicolumn{3}{|c|}{ Prerequisite of Quality } \\
\hline 0.2 .1 & $\begin{array}{l}\text { - Significant resources will be needed to improve the quality of the } \\
\text { PPI. }\end{array}$ & $\begin{array}{l}\text { Short } \\
\text { term }\end{array}$ \\
\hline 0.3 .1 & $\begin{array}{l}\text { Establish regular mechanisms to consult data users to monitor the } \\
\text { relevance of the statistics and to identify their information needs } \\
\text { (preferably through users' surveys). }\end{array}$ & $\begin{array}{l}\text { Medium } \\
\text { term }\end{array}$ \\
\hline 0.4 .2 & $\begin{array}{l}\text { - Prepare monthly reports to inform management of the quality of } \\
\text { surveys' data (surveys' response rate, coverage, response errors, } \\
\text { etc.). }\end{array}$ & $\begin{array}{l}\text { Short } \\
\text { term }\end{array}$ \\
\hline \multicolumn{3}{|c|}{ Methodological Soundness } \\
\hline 2.1 .1 & $\begin{array}{l}\text { - Adopt the concepts and definitions following the } 1993 \mathrm{SNA} \text {, such } \\
\text { as the inclusion of new PPI weights, changes in inventories, and } \\
\text { own-account production for final use. }\end{array}$ & $\begin{array}{l}\text { Medium } \\
\text { term }\end{array}$ \\
\hline 2.2 .1 & $\begin{array}{l}\text { - Formulate a general plan for expand industrial activity coverage, } \\
\text { compiling updated weights and reference base, following } \\
\text { international standards. }\end{array}$ & $\begin{array}{l}\text { Short } \\
\text { term }\end{array}$ \\
\hline 2.3 .1 & $\begin{array}{l}\text { - Define the basket of a new CPI using systems broadly consistent } \\
\text { with internationally accepted standards, in accordance with } \\
\text { - } 1993 \text { SNA } \\
\text { - International Standard Industrial Classification (ISIC Rev.3) } \\
\text { - Central Product Classification (CPC) }\end{array}$ & $\begin{array}{l}\text { Medium } \\
\text { term }\end{array}$ \\
\hline \multicolumn{3}{|c|}{ Accuracy and Reliability } \\
\hline 3.1 .1 & $\begin{array}{l}\text { - Formulate a general plan for increase basket of goods coverage, } \\
\text { using data from the supply/use tables based on the new national } \\
\text { accounts series. }\end{array}$ & $\begin{array}{l}\text { Medium } \\
\text { term }\end{array}$ \\
\hline 3.2 .1 & $\begin{array}{l}\text { - Asses PPI data source to prices surveys and improvement the } \\
\text { efficiency of sampling techniques. }\end{array}$ & $\begin{array}{l}\text { Short } \\
\text { term }\end{array}$ \\
\hline 3.2 .1 & $\begin{array}{l}\text { - Asses PPI data source and calculate response rate, coverage, } \\
\text { response errors, etc. }\end{array}$ & $\begin{array}{l}\text { Short } \\
\text { term }\end{array}$ \\
\hline 3.3 .1 & $\begin{array}{l}\text { - Employ better statistical techniques to improve treatment of } \\
\text { seasonal products, missing items, quality changes, and } \\
\text { introduction of new products. }\end{array}$ & $\begin{array}{l}\text { Short } \\
\text { term }\end{array}$ \\
\hline
\end{tabular}




\begin{tabular}{|c|c|c|}
\hline 3.3 .2 & $\begin{array}{l}\text { - Adopt the recommendations in the } 1993 S N A \text { and the new PPI } \\
\text { Manual 2004, including: } \\
\text { - Use of the geometric mean for price changes } \\
\text { - Calculation of retroactive index series using chain linking, } \\
\text { between old a new series. }\end{array}$ & $\begin{array}{l}\text { Medium } \\
\text { term }\end{array}$ \\
\hline 3.5 .1 & - Undertake periodic revision studies. & $\begin{array}{l}\text { Short } \\
\text { term }\end{array}$ \\
\hline 3.5 .1 & - $\quad$ Base PPI updates on a program of regular censuses and surveys. & $\begin{array}{l}\text { Long } \\
\text { term }\end{array}$ \\
\hline \multicolumn{3}{|c|}{ Serviceability } \\
\hline 4.1.1 & - Improve the periodicity of the PPI. & $\begin{array}{l}\text { Short } \\
\text { term }\end{array}$ \\
\hline 4.1 .2 & - Improve the timeless of the PPI. & $\begin{array}{l}\text { Short } \\
\text { term }\end{array}$ \\
\hline 4.3 .1 & - Normalize the revisions periodicity. & $\begin{array}{l}\text { Short } \\
\text { term }\end{array}$ \\
\hline 4.3 .3 & $\begin{array}{l}\text { - Document and disseminate the analysis of differences between } \\
\text { revised and preliminary data. }\end{array}$ & $\begin{array}{l}\text { Medium } \\
\text { term }\end{array}$ \\
\hline \multicolumn{3}{|c|}{ Accessibility } \\
\hline 5.1.3. & $\begin{array}{l}\text { - Disseminate a preannounced schedule with the dates the statistics } \\
\text { are to be released, and release statistics according to the } \\
\text { preannounced schedule. }\end{array}$ & $\begin{array}{l}\text { Short } \\
\text { term }\end{array}$ \\
\hline
\end{tabular}


E. Government Finance Statistics

\begin{tabular}{|c|c|c|}
\hline $\begin{array}{l}\text { DQAF } \\
\text { Code }\end{array}$ & Planned Actions & Timing \\
\hline \multicolumn{3}{|c|}{ Prerequisite of Quality } \\
\hline 0.1 .1 & $\begin{array}{l}\text { - Coordination between the two units of the MOF that share the } \\
\text { responsibility of GFS compilation should be improved for } \\
\text { comprehensive collection, compilation and dissemination of } \\
\text { GFS. }\end{array}$ & $\begin{array}{l}\text { Short } \\
\text { term }\end{array}$ \\
\hline 0.1 .2 & $\begin{array}{l}\text { - Intra and inter-agency data sharing and coordination between } \\
\text { the MOF and data-producing public entities should be } \\
\text { improved. }\end{array}$ & $\begin{array}{l}\text { Short } \\
\text { term }\end{array}$ \\
\hline 0.2 .1 & $\begin{array}{l}\text { - Additional personnel, computing, and financing resources are } \\
\text { required to perform new collection, compilation, and } \\
\text { dissemination tasks to improve GFS quality, such as an } \\
\text { expansion of the institutional and transaction coverage of the } \\
\text { GFS already compiled, and the implementation of the GFSM } \\
2001 \text { analytical framework. }\end{array}$ & $\begin{array}{l}\text { Medium } \\
\text { term }\end{array}$ \\
\hline \multicolumn{3}{|c|}{ Assurances of integrity } \\
\hline 1.2 .3 & $\begin{array}{l}\text { - Clearly identify data sources and the entity in charge of data } \\
\text { compilation in all statistical products. }\end{array}$ & $\begin{array}{l}\text { Short } \\
\text { term }\end{array}$ \\
\hline 1.2 .4 & $\begin{array}{l}\text { Provide advance notice of all methodological and other } \\
\text { relevant changes that materially affect the GFS. }\end{array}$ & $\begin{array}{l}\text { Short } \\
\text { term }\end{array}$ \\
\hline \multicolumn{3}{|c|}{ Methodological Soundness } \\
\hline 2.1 .1 & $\begin{array}{l}\text { Develop a plan to migrate to the GFSM } 2001 \text { analytical } \\
\text { framework. Current GFS compilation using the GFSM } 2001 \\
\text { methodology by the GDA should be coordinated among } \\
\text { relevant units and institutions involved in the GFS } \\
\text { compilation. }\end{array}$ & $\begin{array}{l}\text { Medium } \\
\text { term }\end{array}$ \\
\hline 2.2 .1 & $\begin{array}{l}\text { - (i) Expand the scope of institutions and transactions in the } \\
\text { GFS to include comprehensive and detailed data of the } \\
\text { operations of some decentralized agencies and local } \\
\text { governments; (ii) make special efforts to compile debt data of } \\
\text { local governments; and (iii) expand coverage of domestic } \\
\text { debt. }\end{array}$ & $\begin{array}{l}\text { Medium } \\
\text { term }\end{array}$ \\
\hline
\end{tabular}




\begin{tabular}{|c|c|c|}
\hline 2.3 .1 & $\begin{array}{l}\text { - Adopt sectorization and classification systems recommended } \\
\text { in the GFS manuals, including: } \\
\text { - Compile and disseminate data for central government } \\
\text { including budgetary, extrabudgetary, and social security } \\
\text { operations. } \\
\text { - Compile GFS for the social security sector, including data } \\
\text { of the Corporation of Military Social Insurance. } \\
\text { - Reclassify royalties as other revenue item; commissions for } \\
\text { interest as good and service item; tax refunds as a revenue } \\
\text { item; social assistance benefits as transfers to households; } \\
\text { repayments as an expense item and present a net item, } \\
\text { lending minus repayments; and payments for pensions as } \\
\text { compensation of employee item. } \\
\text { - Reclassify as other capital revenue two categories wrongly } \\
\text { classified as current revenue, "other capital revenue" and } \\
\text { "other revenues", the part corresponding to capital } \\
\text { revenue. } \\
\text { Collect and compile disaggregated data for some items } \\
\text { included in expenses, such "universities" and "others", to } \\
\text { obtain an adequate economic classification. }\end{array}$ & $\begin{array}{c}\text { Short } \\
\text { term }\end{array}$ \\
\hline 2.4 .1 & $\begin{array}{l}\text { - Value public external and domestic debt at face value if the } \\
\text { GFSM } 1986 \text { methodology is used or at market prices if the } \\
\text { GFSM } 2001 \text { methodology is used. Nominal values can be } \\
\text { shown as memorandum items. }\end{array}$ & $\begin{array}{c}\text { Medium } \\
\text { term }\end{array}$ \\
\hline 2.4 .2 & $\begin{array}{l}\text { - Compile GFS data on noncash and cash bases. Both bases of } \\
\text { recording are relevant for policy analysis and they should be } \\
\text { consistent. }\end{array}$ & $\begin{array}{c}\text { Medium } \\
\text { term }\end{array}$ \\
\hline 2.4 .3 & $\begin{array}{l}\text { Taxes should include tax refunds, and be netted from the } \\
\text { correspondent tax, if possible, and lending minus repayment } \\
\text { should be included as an expense category (when using the } \\
\text { GFSM } 1986 \text { methodology). }\end{array}$ & $\begin{array}{l}\text { Short } \\
\text { term }\end{array}$ \\
\hline \multicolumn{3}{|c|}{ Accuracy and Reliability } \\
\hline 3.1 .1 & $\begin{array}{l}\text { - (i) devote financial, human, and computing resources to } \\
\text { integrate data sources for improving consistency of the GFS } \\
\text { and for reducing the collection and compilation burden, and } \\
\text { (ii) expand institutional coverage of the SIGMA to include } \\
\text { information collected by the SINCON and other financial } \\
\text { systems. }\end{array}$ & $\begin{array}{c}\text { Medium } \\
\text { term }\end{array}$ \\
\hline 3.5 .1 & - Document revision studies and analysis of revisions. & $\begin{array}{c}\text { Medium } \\
\text { term }\end{array}$ \\
\hline
\end{tabular}




\begin{tabular}{|c|ll|c|}
\hline \multicolumn{3}{|c|}{ Serviceability } \\
\hline 4.2 .3 & $\bullet \quad \begin{array}{l}\text { Reconcile GFS with the national accounts to ensure } \\
\text { consistency. }\end{array}$ & $\begin{array}{c}\text { Short } \\
\text { term }\end{array}$ \\
\hline 4.3 .1 & $\bullet$ & Make the revision schedule known to the public. & $\begin{array}{c}\text { Short } \\
\text { term }\end{array}$ \\
\hline 4.3 .3 & $\bullet \quad \begin{array}{l}\text { Include explanatory notes of revisions in published tables and } \\
\text { disseminate studies and analysis of revisions. }\end{array}$ & $\begin{array}{c}\text { Short } \\
\text { term }\end{array}$ \\
\hline 5.1 .1 & $\bullet \quad \begin{array}{l}\text { Improve the presentation of GFS on the website or in hard } \\
\text { copy. }\end{array}$ & $\begin{array}{c}\text { Short } \\
\text { term }\end{array}$ \\
\hline 5.2 .1 & $\bullet \quad \begin{array}{l}\text { Post detailed GFS detailed metadata and a link to the IMF's } \\
\text { DSBB on the MOF website. }\end{array}$ & $\begin{array}{c}\text { Short } \\
\text { term }\end{array}$ \\
\hline
\end{tabular}




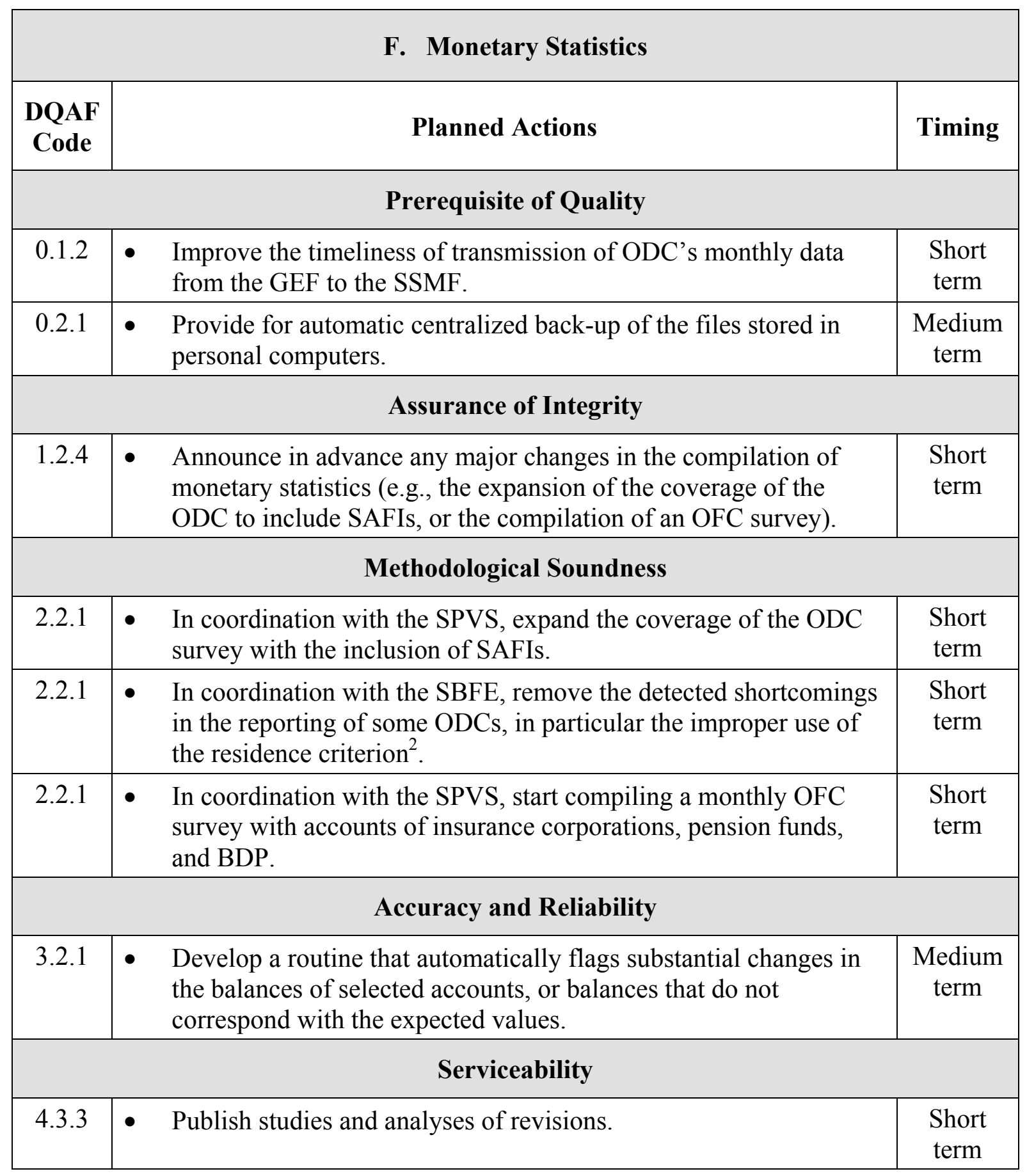

\footnotetext{
${ }^{2}$ Every three months, the CBB will send to the SBFE notes with the observations.
} 
G. Balance of Payments Statistics

\begin{tabular}{|c|c|c|}
\hline $\begin{array}{l}\text { DQAF } \\
\text { Code }\end{array}$ & Planned Actions & Timing \\
\hline \multicolumn{3}{|c|}{ Prerequisite of Quality } \\
\hline 0.1 .4 & $\begin{array}{l}\text { - Include in CBB's questionnaires and direct reporting forms for } \\
\text { BOP compilation references to the legal basis for collecting } \\
\text { information, including the confidentiality of reported data. }\end{array}$ & $\begin{array}{l}\text { Short } \\
\text { term }\end{array}$ \\
\hline 0.2 .1 & $\begin{array}{l}\text { Provide additional staff to the BPD to undertake tasks associated } \\
\text { with the recent introduction of the CBB's Foreign Private Capital } \\
\text { (FPC) survey. }\end{array}$ & $\begin{array}{l}\text { Short } \\
\text { term }\end{array}$ \\
\hline 0.2 .1 & $\begin{array}{l}\text { Improve BPD staff telephone communications and Internet } \\
\text { access. }\end{array}$ & $\begin{array}{l}\text { Medium } \\
\text { term }\end{array}$ \\
\hline 0.4 .2 & $\begin{array}{l}\text { Prepare monthly reports to inform management of the quality of } \\
\text { data based on direct reporting and surveys. }\end{array}$ & $\begin{array}{l}\text { Short } \\
\text { term }\end{array}$ \\
\hline \multicolumn{3}{|c|}{ Assurances of Integrity } \\
\hline 1.2 .1 & $\begin{array}{l}\text { - Enhance the description in the External Sector Bulletin of the } \\
\text { terms and under which BOP statistics are compiled and } \\
\text { disseminated. }\end{array}$ & $\begin{array}{l}\text { Short- } \\
\text { term }\end{array}$ \\
\hline 1.2 .4 & $\begin{array}{l}\text { - Reinforce the practice of providing advanced notice of major } \\
\text { changes in the compilation of BOP statistics. }\end{array}$ & $\begin{array}{l}\text { Short } \\
\text { term }\end{array}$ \\
\hline \multicolumn{3}{|c|}{ Methodological Soundness } \\
\hline 2.2 .1 & $\begin{array}{l}\text { - In consultation with the NSI, develop a methodology to include } \\
\text { unrecorded trade and its counterpart transactions in BOP } \\
\text { statistics. }\end{array}$ & $\begin{array}{l}\text { Medium } \\
\text { term }\end{array}$ \\
\hline 2.2 .1 & $\begin{array}{l}\text { - Identify in coordination with the MOF ways to gather information } \\
\text { on the ultimate holder of government bonds issued locally. }\end{array}$ & $\begin{array}{l}\text { Medium } \\
\text { term }\end{array}$ \\
\hline 2.2 .1 & $\begin{array}{l}\text { - Assess the extent to which nonresidents' deposits could be } \\
\text { identified from total bank deposits in SBFE data in coordination } \\
\text { with the SSMF. }\end{array}$ & $\begin{array}{l}\text { Medium } \\
\text { term }\end{array}$ \\
\hline 2.3 .1 & $\begin{array}{l}\text { - Classify transactions in services and transfers, and sectorize } \\
\text { institutional units for external debt transactions according to } \\
\text { BPM5 guidelines. }\end{array}$ & $\begin{array}{l}\text { Short } \\
\text { term }\end{array}$ \\
\hline 2.4 .1 & $\begin{array}{l}\text { Adjust flow data derived from BIS stocks data on nonbank } \\
\text { deposits abroad for exchange rate valuation changes. }\end{array}$ & $\begin{array}{l}\text { Short } \\
\text { term }\end{array}$ \\
\hline 2.4 .2 & $\begin{array}{l}\text { - In coordination with the GOI, apply the accrual principle for } \\
\text { recording interest on public external debt. }\end{array}$ & $\begin{array}{l}\text { Medium } \\
\text { term }\end{array}$ \\
\hline
\end{tabular}




\begin{tabular}{|c|c|c|}
\hline 2.4 .2 & - $\quad$ Record dividends when declared payable. & $\begin{array}{l}\text { Short } \\
\text { term }\end{array}$ \\
\hline \multicolumn{3}{|c|}{ Accuracy and Reliability } \\
\hline 3.1 .1 & $\begin{array}{l}\text { - Initiate quarterly FPC surveys in } 2007 \text {, identifying improvements } \\
\text { in design, data validation, and sample techniques, based on the } \\
\text { results of the } 2006 \text { FPC survey. }\end{array}$ & $\begin{array}{l}\text { Short } \\
\text { term }\end{array}$ \\
\hline 3.1 .1 & $\begin{array}{l}\text { - Prepare a comprehensive and up-to-date business register for } \\
\text { sample surveys. }\end{array}$ & $\begin{array}{l}\text { Short } \\
\text { term }\end{array}$ \\
\hline 3.1 .1 & $\begin{array}{l}\text { - Reinforce the use of surveys and direct reporting data for } \\
\text { services. }\end{array}$ & $\begin{array}{l}\text { Short } \\
\text { term }\end{array}$ \\
\hline 3.1 .1 & $\begin{array}{l}\text { - Resume in } 2007 \text { the semiannual travel survey, jointly conducted } \\
\text { by NSI and CBB. }\end{array}$ & $\begin{array}{l}\text { Short } \\
\text { term }\end{array}$ \\
\hline 3.1 .3 & $\begin{array}{l}\text { - Subject to staff availability and improvements in the telephone } \\
\text { communications, the CBB may employ more rigorous follow-up } \\
\text { procedures to ensure the timely receipt of respondents' data on } \\
\text { services, remittances, and foreign private capital. }\end{array}$ & $\begin{array}{l}\text { Short } \\
\text { term }\end{array}$ \\
\hline 3.3 .1 & $\begin{array}{l}\text { - Review statistical techniques to adjust data for missing } \\
\text { observations on services, remittances, and foreign private capital. }\end{array}$ & $\begin{array}{l}\text { Medium } \\
\text { term }\end{array}$ \\
\hline 3.3 .2 & $\begin{array}{l}\text { - Continue efforts to improve data collection and estimation } \\
\text { techniques for workers' remittances and other transfers, and } \\
\text { certain services and financial transactions. }\end{array}$ & $\begin{array}{l}\text { Medium } \\
\text { term }\end{array}$ \\
\hline 3.3 .2 & $\begin{array}{l}\text { - Review estimates on direct investment with the view to avoid } \\
\text { overestimation of investment income and reinvested earnings. }\end{array}$ & $\begin{array}{l}\text { Medium } \\
\text { term }\end{array}$ \\
\hline 3.4 .3 & $\begin{array}{l}\text { - In coordination with the GOI, compare data on selected external } \\
\text { debt transactions with the Joint BIS-IMF-OECD-World Bank } \\
\text { external debt table and the BIS locational banking statistics. }\end{array}$ & $\begin{array}{l}\text { Short } \\
\text { term }\end{array}$ \\
\hline 3.4 .3 & $\begin{array}{l}\text { - Reconcile regularly trade data using partner-country data to adjust } \\
\text { for possible miss coverage of exports and imports. }\end{array}$ & $\begin{array}{l}\text { Medium } \\
\text { term }\end{array}$ \\
\hline \multirow[t]{2}{*}{3.5 .1} & $\begin{array}{l}\text { - Document studies and analysis of revisions and use these results } \\
\text { to inform the statistical process. }\end{array}$ & $\begin{array}{l}\text { Short } \\
\text { term }\end{array}$ \\
\hline & Serviceability & \\
\hline 4.2.1. & - Closely monitor the BOP errors and omissions. & $\begin{array}{l}\text { Short } \\
\text { term }\end{array}$ \\
\hline 4.2 .1 & $\begin{array}{l}\text { Produce and disseminate on a regular basis a summary table on } \\
\text { BOP and IIP data consistency (identifying initial stock, } \\
\text { transactions, other changes, and final stock). }\end{array}$ & $\begin{array}{l}\text { Short } \\
\text { term }\end{array}$ \\
\hline 4.2 .2 & $\begin{array}{l}\text { - Revise the data series prior to } 2006 \text { in order to reclassify Bolivia's } \\
\text { contributions to FLAR from reserve assets to other CBB's } \\
\text { external assets. }\end{array}$ & $\begin{array}{l}\text { Short } \\
\text { term }\end{array}$ \\
\hline
\end{tabular}




\begin{tabular}{|c|c|c|}
\hline 4.2 .3 & $\begin{array}{l}\text { - Establish regular mechanisms for enhancing data consistency } \\
\text { with national accounts statistics. }\end{array}$ & $\begin{array}{l}\text { Medium } \\
\text { term }\end{array}$ \\
\hline 4.2 .3 & $\begin{array}{l}\text { - Prepare and disseminate a table on quarterly reserves assets } \\
\text { reconciliation between monetary and BOP statistics in } \\
\text { coordination with the SSMF. }\end{array}$ & $\begin{array}{l}\text { Short } \\
\text { term }\end{array}$ \\
\hline 4.3 .1 & - $\quad$ Strengthen data revision policies and practices. & $\begin{array}{l}\text { Short- } \\
\text { term }\end{array}$ \\
\hline 4.3 .1 & - Publicize the revision cycle for BOP data on the $\mathrm{CBB}$ website. & $\begin{array}{l}\text { Medium } \\
\text { term }\end{array}$ \\
\hline \multicolumn{3}{|c|}{ Accessibility } \\
\hline 5.1 .1 & $\begin{array}{l}\text { - In coordination with the GOI, initiate the dissemination of the } \\
\text { public- and publicly-guaranteed external debt service schedule } \\
\text { recommended by the GDDS on the CBB website. }\end{array}$ & $\begin{array}{l}\text { Medium } \\
\text { term }\end{array}$ \\
\hline 5.1 .1 & $\begin{array}{l}\text { - In coordination with the GOI, initiate the dissemination of the } \\
\text { SDDS prescribed external debt position data category (by } \\
\text { institutional sector of the debtor, maturity, and type of instrument) } \\
\text { on the CBB website. }\end{array}$ & $\begin{array}{l}\text { Short- } \\
\text { term }\end{array}$ \\
\hline 5.1 .1 & $\begin{array}{l}\text { - In coordination with the GOI, initiate participation in the World } \\
\text { Bank's quarterly external debt statistics (QEDS) database, by } \\
\text { reporting the SDDS prescribed external debt table. }\end{array}$ & $\begin{array}{l}\text { Short- } \\
\text { term }\end{array}$ \\
\hline 5.1 .1 & $\begin{array}{l}\text { - In coordination with the GOI, compile and disseminate other } \\
\text { QEDS tables relevant for Bolivia in the CBB website. }\end{array}$ & $\begin{array}{l}\text { Medium } \\
\text { term }\end{array}$ \\
\hline 5.1 .1 & $\begin{array}{l}\text { - Initiate the monthly reporting of the reserve template with one- } \\
\text { month lag to STA for its redissemination on the IMF website. }\end{array}$ & $\begin{array}{l}\text { Short } \\
\text { term }\end{array}$ \\
\hline 5.1 .1 & $\begin{array}{l}\text { - Disseminate monthly series of the reserve template on the CBB } \\
\text { website. }\end{array}$ & $\begin{array}{l}\text { Short } \\
\text { term }\end{array}$ \\
\hline
\end{tabular}


INTERNATIONAL MONETARY FUND

BOLIVIA

Detailed Assessments Using the Data Quality Assessment Framework (DQAF)

Prepared by the Statistics Department

Approved by Robert W. Edwards and Anoop Singh

August 2, 2007

This document contains a detailed assessment by dataset of the elements and indicators that underlie the data quality dimensions discussed in Bolivia's Report on the Observance of Standards and Codes (ROSC) - Data Module. It also includes, as appendices, (i) summaries of the General Data Dissemination System (GDDS) and the Special Data Dissemination Standard (SDDS), (ii) a summary table of Bolivia's data dissemination practices compared to the SDDS Coverage, Periodicity, and Timeliness of Data, (iii) the DQAF generic framework, and (iv) the results of the users' survey. 
Contents

Page

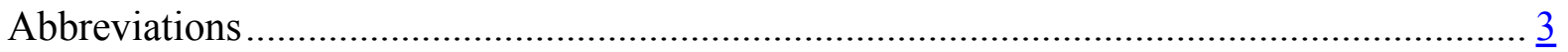

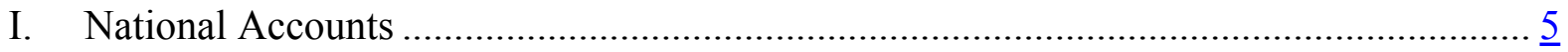

II. Price Statistics (Consumer Price Index) ................................................................. $\frac{36}{60}$

III. Price Statistics (Producer Price Index) ................................................................. $\frac{60}{81}$

IV. Government Finance Statistics ...................................................................... $\frac{81}{01}$

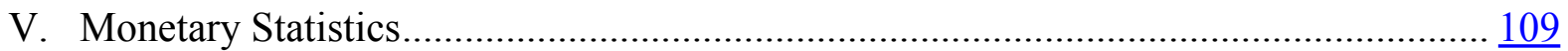

VI. Balance of Payments Statistics ............................................................................. 132

Tables

1. DQAF (July 2003): Summary of Results for National Accounts .....................................

2. DQAF (July 2003): Summary of Results for Price Statistics (Consumer Price Index)...... $\underline{57}$

3. DQAF (July 2003): Summary of Results for Price Statistics (Producer Price Index)........79

4. DQAF (July 2003): Summary of Results for Government Finance Statistics.................106

5. DQAF (July 2003): Summary of Results for Monetary Statistics................................130

6. DQAF (July 2003): Summary of Results for Balance of Payments Statistics.................156

Appendices

I. Summary of the General Data Dissemination System (GDDS) ..................................158

II. Summary of the Special Data Dissemination Standard (SDDS) ............................... $\frac{160}{164}$

III. Data Quality Assessment Framework - Generic Framework....................................164

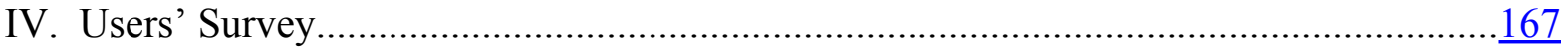

V. Comments by Users of Macroeconomic Statistics …............................................ 173

Appendix Tables

7: Practices Compared to the SDDS Coverage, Periodicity, and Timeliness of Data ..........162

8: Questionnaire Results Analyzed by Type of User ...................................................169

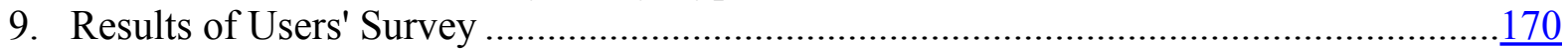




\section{AbBreviations}

$\begin{array}{ll}1968 \text { SNA } & \text { System of National Accounts } 1968 \\ \text { 1993 SNA } & \text { System of National Accounts 1993 } \\ \text { APEC } & \text { Economic Policy Advisory Office, CBB } \\ \text { BIS } & \text { Bank for International Settlements } \\ \text { BOP } & \text { Balance of Payments } \\ \text { BPD } & \text { Balance of Payments Department, CBB } \\ \text { BPM5 } & \text { Balance of Payments Manual, fifth edition } \\ \text { CAN } & \text { Andean Community of Nations } \\ \text { CBB } & \text { Central Bank of Bolivia } \\ \text { CEMLA } & \text { Latin American Monetary Studies Center } \\ \text { CHS } & \text { Continuous Household Survey } \\ \text { COFOG } & \text { Functional Classification of Government Expenditures } \\ \text { COICOP } & \text { Classification of Individual Consumption by Purpose } \\ \text { CPC } & \text { Central Product Classification } \\ \text { CPI } & \text { Consumer Price Index } \\ \text { DCS } & \text { Depository Corporations Survey } \\ \text { DEIE } & \text { Statistics and Economic Indicators Direction } \\ \text { DFI } & \text { Development Finance International } \\ \text { DL } & \text { Decree-Law } \\ \text { DMFAS } & \text { Debt Management and Financial Analysis System, UNCTAD } \\ \text { DQAF } & \text { Data Quality Assessment Framework, July 2003 } \\ \text { DRI } & \text { Debt Relief International } \\ \text { DSBB } & \text { Dissemination Standards Bulletin Board } \\ \text { ECLAC } & \text { Economic Commission for Latin America and the Caribbean } \\ \text { External Debt Guide } & \text { External Debt Statistics: Guide for Compilers and Users } \\ \text { FDI } & \text { Foreign direct investment } \\ \text { FISIM } & \text { Financial intermediation services indirectly measured } \\ \text { FLAR } & \text { Latin-American Reserves Fund } \\ \text { FONDESIF } & \text { Financial System Development Fund } \\ \text { FPC } & \text { Foreign Private Capital } \\ \text { GDA } & \text { General Directorate of Accounting, MOF } \\ \text { GEF } & \text { Financial Entities Management Office, CBB } \\ \text { GDDS } & \text { General Data Dissemination System } \\ \text { GDP } & \text { Gross Domestic Product } \\ \text { GFCF } & \text { Gross Fixed Capital Formation } \\ \text { GFS } & \text { Government Finance Statistics } \\ \text { GFSM 1986 } & \text { A Manual on Government Finance Statistics, 1986 } \\ \text { GFSM 2001 } & \text { Government Financial Statistics Manual 2001 } \\ \text { GOI } & \text { International Operations Management Office, CBB } \\ \text { GOM } & \text { Monetary Operations Management Office, CBB } \\ \text { HBS } & \text { Household Budget Survey } \\ \text { HIPC } & \text { Inghly Indebted Poor Countries } \\ \text { IDB } & \text { Inter-American Development Bank } \\ \text { ILO } & \end{array}$




\begin{tabular}{|c|c|}
\hline IIP & International Investment Position \\
\hline IMF & International Monetary Fund \\
\hline ISIC & International Standard Industrial Classification \\
\hline ISWGNA & Intersecretariat Working Group on National Accounts \\
\hline MECOVI & Measurement of Living Conditions \\
\hline MERCOSUR & Common Market of the South \\
\hline MFSM & Monetary and Financial Statistics Manual \\
\hline MOF & Ministry of Finance \\
\hline NAD & National Accounts Directorate, NSI \\
\hline NAFIBO & Bolivian National Finance Company \\
\hline NPISH & Nonprofit Institutions Serving Households \\
\hline NSI & National Statistics Institute \\
\hline $\mathrm{ODC}$ & Other Depository Corporations \\
\hline $\mathrm{OFC}$ & Other Financial Corporations \\
\hline PPI & Producer Price Index \\
\hline QMS & Quarterly Manufacturing Survey \\
\hline QEDS & Quarterly External Debt Statistics, World Bank \\
\hline RAF & Fiscal Analysis Network \\
\hline Reserves template & International Reserves and Foreign Currency Liquidity Data Template \\
\hline ROSC & Report on the Observance of Standards and Codes \\
\hline SAFI & Investment Funds Management Societies \\
\hline SBFE & Superintendency of Banks and Financial Entities \\
\hline $\mathrm{SC}$ & Accounting Deputy Management Office, CBB \\
\hline SDDS & Special Data Dissemination Standard \\
\hline SINCON & Integrated Accounting System \\
\hline SIGMA & Integrated System of Management and Administrative Modernization \\
\hline SNIE & National Statistical Information System \\
\hline SPSI & Superintendency of Pensions, Securities, and Insurances \\
\hline SSE & External Sector Deputy Management Office, CBB \\
\hline SSMF & Monetary and Fiscal Sector Deputy Management Office, CBB \\
\hline STA & Statistics Department, IMF \\
\hline S\&U & Supply and Use Table \\
\hline UDAPE & Economic Policy Analysis Unit \\
\hline UEIAE & Statistic and Economic Activity Indicators Unit, NSI \\
\hline UNCTAD & United Nations Conference for Trade and Development \\
\hline UFV & Housing Promotion Unit \\
\hline UPF & Fiscal Programming Unit, MOF \\
\hline UREIP & Register, Statistics, and Prices Indicators Unit, NSI \\
\hline YPFB & Yacimientos Petrolíferos Fiscales Bolivianos \\
\hline
\end{tabular}




\section{Detailed AsSessment Using The Data Quality Assessment Framework (DQAF)}

The following detailed information on indicators of statistical practices in the areas of the national accounts, prices, government finance, money and banking, and balance of payments statistics was gathered from publicly available documents and information provided by the Bolivian officials. This information, which is organized along the lines of the generic DQAF (see Appendix II), was used to prepare the summary assessment of data quality elements, based on a four-part scale of observance, shown in Bolivia's Report on the Observance of Standards and Codes (ROSC)—Data Module.

\section{National ACCOUNTS}

\section{Prerequisites of quality}

\subsection{Legal and institutional environment}

\subsubsection{The responsibility for collecting, processing, and disseminating the statistics is clearly specified}

Provisions for producing statistics are included in the Decree-Law (DL) 14100, from November 5, 1976, which creates the National System of Statistical Information, but did not assign the responsibility for compiling the national accounts to the National Statistics Institute (NSI). The accounts were previously produced by the Central Bank of Bolivia (CBB) on the basis of the Supreme Decree 12352 from April 8, 1975. However the Supreme Decree 21855, from January 14, 1988, transferred this responsibility to the NSI, where they are compiled by the National Accounts Directory (NAD). The NSI is a decentralized entity allocated at present to the Ministry of Development Planning.

DL 14100 establishes the National Statistical Council (NSC) as the maximum decision organ of the System, with the objective of defining the statistics production policies. The main functions of the NSI are governed by the following articles: (1) Article 5 states that the NSI is responsible for managing, planning, executing, supervising, and coordinating the System's activities; (2) Article 8 allows the NSI to issue technical standards applicable to the statistical activities of the institutions and agencies that make up the System, in order to standardize statistical compilation and avoid duplication of effort; and (3) Article 15 makes mandatory to all individuals and legal entities in Bolivia, residents and nonresidents alike, to submit data and information that, owing to its nature and purpose, is relevant to the activities of the System and has been requested by the NSI. Technical committees for statistics coordination are contemplated, in order to integrate the statistical work of private and public entities. The NSI is empowered to create the committees and to define their composition and attributions.

Article 25 mentions that the National Statistical Council shall be authorized to determine the system's internal disciplinary measures for the violations referred to in this DL and in the 
regulations of the System, independently of those established in the Criminal Code and other provisions in force.

Although DL 14100 gives ample powers to the NSI, in practice it does not have the legal authority or resources to perform the functions assigned by the legislation. The DL has partially lost its relevance, as new laws with a higher legal power than the DL have been created, reducing the NSI's effective legal power, for example, by limiting access to information generated by various public entities.

A project of a new Statistics Law has been prepared. It will be presented to the Ministry of Development Planning for its consideration, and then it will be sent to Congress for its approval.

Recommendation: Give high priority to the approval of the new Statistics Law.

\subsubsection{Data sharing and coordination among data-producing agencies are adequate}

Bilateral arrangements have been established and agreements signed by the NSI with various institutions in order to provide for an effective and timely flow of administrative and survey data, among them the CBB, the Vice Ministry of Migration, the Vice Ministry of Tourism, the Superintendency of Communications, and the Ministry of Hydrocarbons. Also, more contacts and meetings are maintained during recent months to promote a proper understanding of data requirements in connection with the ongoing work for updating the national accounts reference year. Nevertheless, data sharing and coordination with the CBB and the Ministry of Finance (MOF) could be improved.

Potential conflicts between NSI's legal authority provided by the DL 14100 to produce the statistics, and the restrictions generated by other laws related to other public institutions with higher legal power than DL 14100, have been partially avoided by agreements between the NSI and different institutions. For instance, access to the database of the tax authority is not allowed, but aggregate data for the national accounts compilation is provided to the NSI with a detail agreed by both institutions, protecting the confidentiality of individual reports. On the other hand, access to the list of enterprises reporting to the tax authority and some additional information, e.g., their address, is urgently needed in order to actualize the NSI's Enterprise Directory, but access to the information has been denied.

\subsubsection{Individual reporters' data are to be kept confidential and used for statistical purposes only}

The above mentioned DL 14100 clearly protects the confidentiality of individual data. Article 21 stipulates that "data and information obtained by the System shall be strictly confidential and used only for statistical purposes. No individualized data or information may be disclosed, administrative and judicial agencies shall not request individualized information, and results may be disseminated or published only if they contain no identifying information." Article 22 specifies that "To ensure the statistical confidentiality established in 
the preceding article, all institutions in the System and their employees shall be prohibited from providing or supplying data in violation of the provisions contained in the preceding article." Article 23 adds that persons that are involved in the preparation and execution of statistical activities of the System will formulate only questions included in the approved questionnaires or instructions related to them. Absolute reserve should be maintained by staff involved on the corresponding activities. In addition, Article 24 establishes that all computing files and databases electronically generated should contain security systems and protection of the collected information.

The NSI has adopted adequate measures to prevent the disclosure of individual data, including among others: access to individual data is restricted to staff who require the information in the performance of their statistical duties; special aggregation rules are used to prevent residual disclosure when aggregations of survey or other confidential data are disseminated; confidentiality of data is appropriately guarded during storage and during the process of the destruction of written forms; access to the building is controlled by security personnel; and penalties against staff who disclose confidential data are established in the NSI's Staff Rules.

In all censuses and surveys' questionnaires, respondents are informed of the legal obligation to provide the requested information, on its confidential nature and that it will be only used for the purpose of producing statistics. Interinstitutional formal agreements signed by the NSI contain clauses to assure the confidentiality of data provided through them.

\subsubsection{Statistical reporting is ensured through legal mandate and/or measures to encourage response}

Article 15 of the DL 14100 provides the legal support required for collecting information needed for the production of statistics. As mentioned under 0.1 .3 , confidentiality of provided information is ensured. Although reporting is mandatory, the legislation does not contemplate sanctions to the respondents for non compliance (by not providing the required information or misreporting it). The NSI tries to obtain the voluntary cooperation of the respondents. Mechanisms are in place and measures have been adopted to encourage adequate data reporting, e.g., the response burden is carefully analyzed when programming censuses and surveys, in order to reduce it as much as possible; points of contact are included in the questionnaires to assist respondents.

\section{$0.2 \quad$ Resources}

\subsubsection{Staff, facilities, computing resources, and financing are commensurate with statistical programs}

Serious budget constrains in the last years affected plans to widen the scope of economic statistics and reduced some ongoing activities, like the important annual manufacture survey, which was conducted since 1992, but interrupted in 2003. Also the NAD staff was reduced from 19 to 15 persons. The NAD has at present a permanent staff of 17 employees that work 
on the routine compilation of the national accounts with reference year 1990. To update the reference year and implement the 1993 SNA, preparatory work started in October 2006, for which reason 20 new employees have been hired and assigned to the NAD.

All permanent professional employees have a university degree in statistics, economics, and other related areas. The permanent staff has an average of eight years of work at the NSI. Three of the new contracted staff have worked previously in the NAD. Training has been provided through various internal and international seminars and workshops. Employees have also benefited from on-the-job training by working with international experts visiting NSI on technical assistance missions.

Even though wages of specialists were increased in 2006, their present level is still uncompetitive compared to other public institutions, for similar qualifications and functions. It is quite difficult to find adequate candidates to fill in the vacancies created in the NAD, mainly due to the academic and skill levels requirements, as established in the Individual Annual Operative Program assigned to each post vis-à-vis the offered compensation.

Computing resources for compiling the statistics are now adequate to perform the required tasks, as 27 new computers have been recently acquired with state-of-the-art software in the framework of the ongoing project to update the reference year of the national accounts. Adequate protection is provided for computer resources.

Regarding physical facilities, the NSI's central building has been recently renewed. However, it requires urgent repairs, as the building has structural problems. In the technical area building, heavy documentation had to be moved to another building to avoid the risk of a collapse. The regional offices also need repairs, they are overcrowded, and among other requirements need furniture to perform their current statistical tasks. Technical assessments of required major repairs have been conducted and, with a donation of the Japanese government, work has already started in the departmental offices in Beni and Santa Cruz, and will start in the NSI's central and other departmental offices in a few months.

With reference to funding resources, the NSI suffered serious budget constrains in the last years that affected plans to widen the scope of economic statistics and reduced some ongoing activities and personnel. As stated in the introduction of the Institutional Strategic Plan mentioned above, the NSI's budget for 2005 was 37 percent lower than for 2002, at current prices. As a result, various surveys were discontinued and programmed new activities suspended (see 3.1.1). Nevertheless, as mentioned previously, NAD's staff has been recently increased to implement a project to modernize the national accounts. International support has been secured for various statistical activities included in the NSI's Institutional Strategic Plan for the period 2005-2009.

Recommendations: (1) Provide resources to establish an adequate data collection program of regular surveys for compiling annual and quarterly national accounts; and (2) make more competitive the wages paid to NSI's technicians. 


\subsubsection{Measures to ensure efficient use of resources are implemented}

The NSI is one of the public institutions engaged in the process of institutional reform of the public administration. New personnel is contracted strictly following the requirements established by the Law of the Public Servant, the norms of the National Service for Personnel Administration (Servicio Nacional de Administración de Personal) and the Civil Service Superintendency (Superintendencia del Servicio Civil).

The staff performance is evaluated three times per year. The Institute's 2005-2009 Institutional Strategic Plan contains the tasks and projects to be performed during this five year period. Annual Operative Plans are established, incorporating specific tasks for each unit.

In order to increase the efficiency of the compilation methods and systems of the national accounts, adopt internationally accepted standards, and follow good practices, the NSI has made ample use of international technical assistance from the IMF, the United Nations, and other international institutions, as well as from the Dutch, Sweden and French international cooperation programs. NAD's specialists actively participate in the Andean Community of Nations (CAN) ${ }^{1}$ seminars and workshops, organized with the aim of increasing the quality and comparability of the national accounts, particularly, the quarterly GDP estimates of the Community country members. In these seminars, the countries methodologies are presented for discussion and evaluation and, when necessary, adjusted by the NAD taking into consideration the other countries experiences, the national supply of statistics and other characteristics. Seven of these seminars have taken place in recent years.

Budgeting procedures are also used to help allocate efficiently the limited resources available to the current tasks and the ones originated in new projects. The planning system constitutes in itself a tool for monitoring the adequate use of resources. The progress on the execution of programmed tasks is carefully monitored and assessed.

\section{$0.3 \quad$ Relevance}

\subsubsection{The relevance and practical utility of existing statistics in meeting users' needs are monitored}

To increase the relevance of the national accounts for users, the Institute works to implement international standards that should better meet users' needs. Bolivia is implementing a project to modernize the national accounts, participates in the GDDS, and is currently in the process of improving the timeliness of various of its statistical products, among other measures, in order to subscribe to the SDDS. NSI's professionals participate periodically and actively in meetings, workshops, seminars and presentations organized by different public

\footnotetext{
${ }^{1}$ Currently, the Community is constituted by the following countries: Bolivia, Ecuador, Peru, and Colombia.
} 
institutions; they also participated in the formulation of the government's National Development Plan and, as mentioned under 0.2.2, in specialized regional seminars. Although the NSI does not have a structured and periodic process to directly consult with the main national accounts data users about their present and new emerging information needs, when planning censuses, surveys, and other statistical activities the needs of current and potential users are taken into consideration, particularly, when defining the set of variables to be investigated and the questionnaires content. Some users' requirements are also received through the e-mail address provided in the website and the Costumers Service Unit.

It is worth mentioning that at the departmental level an important project was implemented on the dissemination of statistical information and training of producers and users, with the support of the United Kingdom's Ministry for International Development. In a period of 18 months, 23 workshops took place with approximately one thousand participants. The experience gained will be used to develop a System of Municipal Information.

Recommendation: Establish a structured and periodic process of consultation with the principal data users, in order to review the usefulness of the presently compiled national accounts series and to identify new and emerging data requirements that could be taken into consideration in the ongoing project of national accounts modernization.

\subsection{Other quality management}

\subsubsection{Processes are in place to focus on quality}

NSI management recognizes the importance of producing good quality statistics. Quality is one of the NSI's Statistical Principles, which are disseminated in publications and posted on the website. In November 2003, the metadata of the main statistical products were revised and evaluated with the assistance of the Canadian Executive Service Organization. The NAD's metadata on quarterly GDP, annual GDP, and departmental GDP aggregates were covered by the evaluation. Also, the participation in the CAN's specialized seminars, as well as the technical assistance received from international organizations and countries (see 0.2.2 above), have allowed the improvement of the quality of the compilation process and generated outputs, in the context of periods of serious resource constrains.

As part of the preliminary work for updating the national accounts reference year and implementing the SNA 1993, various training activities have taken place; the last one on the subject of relations between enterprises financial statements and the national accounting according to the $1993 S N A$, which was also important for the present series, as institutional sector accounts are part of it. Conceptual and on the job training are particularly important due to the limited empirical experience on national accounts compilation process of the new staff contracted to implement the project. 


\subsubsection{Processes are in place to monitor the quality of the statistical program}

The performance of the tasks included in the Annual Operative Plan is monitored and assessed to inform managers on the degree of accomplishments, the reasons for delay and other problems. Also monitored are the commitments to the Statistical Secretariat of the CAN on improvements to be incorporated and timing of data provision. In relation with surveys carried out by the Institute, efficiency in their data collection and processing is monitored on a daily basis. With Swedish cooperation, a permanent consultant has been contracted and is evaluating the national accounts, among other statistical products, and making recommendations to improve their quality.

\subsubsection{Processes are in place to deal with quality considerations in planning the statistical program}

Quality issues are taken into account when planning the Institute's statistical program. The Institutional Strategic Plan for 2005-2009 contemplates starting the process of getting the ISO 9000:2000 quality certification for the Institute's main statistical products, which implies the need of monitoring statistical processes in order to identify where needs of quality improvements exist, and to program and implement the required actions to attend them.

\section{Assurances of integrity}

\subsection{Professionalism}

\subsubsection{Statistics are produced on an impartial basis}

The NSI's Statistical Principle on Integrity states the importance of applying technical considerations, scientific principles and professional ethic in the recollection, compilation and dissemination procedures of statistics. The principle is at present strongly adhered to. Professionalism is promoted, among other measures, by sending compilers to training courses and specialized seminars abroad and receiving technical assistance from other countries and international institutions.

The appointment of the present Executive Director was the result of a transparent process that put emphasis on professional qualifications and performance.

\subsubsection{Choices of sources and statistical techniques as well as decisions about dissemination are informed solely by statistical considerations}

The choices of sources to be used, statistical methods to be applied, and decisions about dissemination are strictly based on technical criteria and cost considerations. For data dissemination, less use is made of hard copy publications due to budget restrictions, favoring the option of posting national accounts related material on the INS website (data, analyses of data, metadata and others). 


\subsubsection{The appropriate statistical entity is entitled to comment on erroneous interpretation and misuse of statistics}

To prevent misinterpretations, disseminated documents include data and their analysis. For instance, the quarterly Analysis of the Economic Activity is posted on the website and contains, among others, a final section with comments on some coverage limitations to allow a better interpretation of the data. The NSI monitors the media coverage of its data through its NAD. Comments are made, as needed, by the NSI Director.

\subsection{Transparency}

\subsubsection{The terms and conditions under which statistics are collected, processed, and disseminated are available to the public}

Various publications and documents of the NSI, disseminated also through its website, reproduce the relevant legal topics. For instance, the NSI's Institutional Strategic Plan for the period 2005-2009 contains a section on legal norms related to the Institute's statistical activity. Also, users who want to access the Institute's database are informed of the specific terms and conditions for statistics dissemination, as they have to accept them. The legislation governing the terms and conditions under which statistics are collected until being disseminated by the NSI is posted on the website. An advance release calendar for NSI products is disseminated on the $\mathrm{CBB}$ website.

\subsubsection{Internal governmental access to statistics prior to their release is publicly identified}

The Macroeconomic Group, ${ }^{2}$ that meets periodically to monitor the macroeconomic and financial developments, receives the latest available monetary and financial information that may or may not have been published. This practice may generate in some cases internal government access prior to their dissemination to the public, but with no interference with their pre-scheduled public dissemination. Internal government access to data before their release to the public is made known to the public on the CBB and IMF websites, but not on the NSI website.

Recommendation: Make the public aware of the internal government access to statistics prior to their release to the public on the NSI website.

\footnotetext{
${ }^{2}$ Currently, the Macroeconomic Group is comprised by the Minister of Finance, the CBB President, the Minister of Planning, the Deputy Ministers of Budget, Treasury, Tax Policy, Public Investment, and Pensions, and the Executive Directors of the NSI, UDAPE, UPF, and the Fiscal Analysis Network (RAF).
} 


\subsubsection{Products of statistical agencies/units are clearly identified as such}

Data disseminated to the public by the NSI are clearly identified as NSI's products by name and logo. Article 20 of DL 14100 establishes the obligation of attribution when the data

produced by one institution are disseminated by other institutions.

\subsubsection{Advance notice is given of major changes in methodology, source data, statistical techniques}

Major changes in the conceptual framework, source data and statistical techniques of the national accounts, such as the introduction of the reference year 1990, are announced to the public in advance.

\subsection{Ethical standards}

\subsubsection{Guidelines for staff behavior are in place and are well known to the staff}

The Law No. 2027, on the Statute of the Public Servant, from October 27, 1999, establishes the rights and obligations of the public servants, including clear guidelines on conflict of interest situations. Article 13 stresses de mandatory obligation for all public entities to adopt an Ethical Code and to implant mechanisms to allow the practical evaluation of its dispositions. The NSI's internal document on Staff Regulations attends this institutional obligation. The law 2027 and the Staff Regulations emphasize adherence to ethical standards. Sanctions for improper behavior by the staff in the performance of their functions are established in the NSI's internal Staff Regulations, in accordance with the Law No.1178, on Governmental Administration and Control.

Staff are reminded periodically of these standards. New staff are made aware of them when joining the Institute, as they must observe them from the moment they become part of NSI.

\section{Methodological soundness}

\subsection{Concepts and definitions}

\subsubsection{The overall structure in terms of concepts and definitions follows internationally accepted standards, guidelines, or good practices}

Although the national accounts are compiled using the 1968 SNA as the conceptual framework, important features of the 1993 SNA have been incorporated, among them: compilation of annual supply and use tables, valuation of output at basic prices, and oil fields exploration registered as gross fixed capital formation (GFCF). 


\section{$2.2 \quad$ Scope}

\subsubsection{The scope is broadly consistent with internationally accepted standards, guidelines, or good practices}

Bolivia's national accounts cover annual and quarterly GDP by expenditure and production approaches at current and constant 1990 prices, annual total GDP by income approach at current prices, annual supply and use tables for 35 economic activities and 35 groups of products at current and constant prices. Quarterly GDP estimates also include seasonally adjusted data. Indirect estimates are made on illegal production linked to the transformation of the coca leaf, in special supply and use accounts open for a "coca enclave," covering transactions on the production and transformation processes, as well as the domestic and foreign trade of the generated output. Indirect estimates are made also for informal industrial and domestic trade activities and foreign trade smuggling. At the departmental level, annual production and GDP data by economic activity at current and constant prices are generated for all nine departments comprising the national territory.

The scope includes also institutional sector accounts, from the production up to the capital account, for the following sectors and subsectors: public administration, public nonfinancial enterprises, financial institutions, households, and private nonfinancial corporations. No separate data are compiled for private nonfinancial corporations and households, which are disseminated in an aggregate form. No data are compiled for NPISH. Pension funds are included in the general government. The scope also includes annual rest of the world accounts (until net lending) and the four Consolidated Accounts from the 1968 SNA.

The following 1993 SNA accounts and tables that the ISWGNA determined as recommended for its implementation are compiled on a regular basis. Quarterly value added and GDP at current and constant prices by activity, quarterly expenditures of GDP at current and constant prices, and annual supply and use tables.

The delimitation of the constituent units of the economy is in accordance with international recommendations. In particular, the following are included as part of the economy: territorial enclaves in the rest of the world, free zones, and workers who work part of the year in another country.

The production boundary includes among others, and in accordance with the 1993 SNA recommendations (independently of actual full coverage), own-account production of all goods for own final consumption, output of goods for own-account fixed capital formation and mineral exploration, illegal output sold to willing buyers. Not included are production of computer software; research and development on own account; production of entertainment, literary, or artistic originals.

In connection with the assets boundary, the national accounts have still not included some new assets incorporated by the $1993 S N A$, among them: defense related assets that could be used for civilian purposes, which are still treated as intermediate consumption following the 
1968 SNA; valuables; agricultural work-in-progress, except the increase in livestock to be used for producing meat; and systems and standard applications computer software and databases (purchased or built in-house). Nevertheless, mineral exploration (whether successful or not) is effectively incorporated in the asset boundary, as recommended by the 1993 SNA.

\section{Oil and gas activities}

The production boundary includes the production of crude oil, natural gas and related products. Also included is the value of production of oil field exploration services, part of which is treated as GFCF. A supply and use account is compiled for oil and gas products. Only foreign enterprises were operating before they were nationalized in May 2006. They are now administrated by the state-owned oil company Yacimientos Petrolíferos Fiscales Bolivianos (YPFB). During 2005, the value added generated by the crude oil and natural gas activity represented 6.3 percent of GDP at current prices. Complete information may be obtained from YPFB, including income flows, although the last ones are not separately identified in the disseminated institutional sector accounts.

\subsection{Classification/sectorization}

\subsubsection{Classification/sectorization systems used are broadly consistent with internationally accepted standards, guidelines, or good practices}

The national classifications of economic activities and products are based on the International Standard Industrial Classification of All Economic Activities (ISIC Rev. 3) (except for agriculture activities) and the Central Product Classification (CPC), respectively. The Classification of Individual Consumption by Purpose (COICOP) is applied to classify households' consumption expenditure by purpose. A functional classification of government expenditures (COFOG) has not been applied.

The classification used for the institutional sectors is an adaptation of the one proposed in the 1968 SNA: public enterprises and quasi-corporate enterprises, private enterprises and quasicorporate enterprises and households, financial institutions, government, and rest of the world (the last one included to record the counterpart of the sectors transactions with non resident institutional units). Households are not classified separately, and non-profit institutions serving households (NPISH) are not investigated.

The classification used for transactions does not cover the financial ones, related to financial assets and liabilities, as they are still not incorporated in the System. For the same reason, no classification has been used for other flows, i.e., changes in assets and liabilities that are not generated by transactions.

Recommendation: Apply COFOG to classify government expenditures by functions. 


\subsection{Basis for recording}

\subsubsection{Market prices are used to value flows and stocks}

The valuation rules used for recording transactions are in broad accordance with the 1993 $S N A$. Production is valued in general at basic prices, while intermediate consumption and other uses are valued at purchaser prices.

Also the valuation rules of the 1993 SNA are applied in some specific cases, among them: output for own use is valued at equivalent market prices, corrections are made when transfer prices are detected, and total imports and exports are valued on an f.o.b. basis. However, foreign trade transactions valued in dollars are converted using the exchange rates applied to exports and imports respectively, which implicitly include financial services.

Recommendation: Apply the mid-point exchange rate prevailing in the market at the moment transactions take place, in order to not incorporate financial services when converting dollars into national currency.

\section{Oil and gas activities}

Output is valued at basic prices, exports at f.o.b prices, imports at c.i.f prices

\subsubsection{Recording is done on an accrual basis}

Transactions are recorded, in principle, on an accrual basis. Preliminary estimates of government related transactions are recorded on a cash basis. However, when accrual data become available, they are incorporated in the revised national accounts figures.

\subsubsection{Grossing/netting procedures are broadly consistent with internationally accepted standards, guidelines, or good practices}

Transactions between establishments belonging to the same enterprise are recorded on a gross basis, to the extent allowed by the data sources.

\section{Accuracy and reliability}

\subsection{Source data}

3.1.1 Source data are obtained from comprehensive data collection programs that take into account country-specific conditions

The supply of economic statistics has been weak in the past and deteriorating in recent years due to a broad fiscal restrain that drastically reduced NSI's resources and forced the suspension of the annual manufacturing, foreign direct investment, and tourism surveys. A programmed economic census, needed for improving the accuracy and reliability of the 
national accounts, was not conducted. The suspension of the important annual manufacture survey in 2003 forced to base the annual estimates for this activity on the quarterly manufacture survey, which has a lower coverage and investigate less variables. This survey has lost coverage due to its 1990 fixed basket of products.

A significant part of the presently disseminated data on the private market activity is not based on regular surveys or current financial statements from enterprises, but rather on the use of partial indicators and fixed 1990 coefficients. The authorities are aware of the weakness of the source data that supports the regular compilation of the present 1990 series and started implementing a project to modernize the national accounts by updating the reference year of the accounts and widening the implementation of the $1993 \mathrm{SNA}$, from which some important elements were incorporated in the present series. As a result, important new statistical activities are being conducted. A wide survey covering mining, manufacture and services was recently conducted, whose data will be used to update the reference year of the national accounts. Also a household survey was conducted in 2004 to update the Consumer Price Index (CPI)'s base year.

The data sources of the data collection program are not sufficient to compile reliable national accounts statistics on a current basis.

Several household surveys have been conducted: the Integrated Households Survey (1989-95) was replaced in 1996 by the National Employment Survey, with a broader coverage that includes data on rural areas. The survey was conducted in 1997, but no survey was carried out in 1998. The survey on measurement of living conditions (MECOVI) replaced the National Employment Survey in 1999, adding a new module on household expenditures and improving the health, education, and migration data. The MECOVI survey has been conducted practically every year since then. A household survey was conducted from November 2003 to November 2004 with the aim of updating the CPI base year. A sample of 9,770 households was selected by using as a sample frame of the 2001 National Population and Housing Census. The sampling techniques are scientific and the probability of selection of households is known. The target population was the households in private dwellings (excluded the collective dwellings), distributed in capital cities, rest of urban, and rural area. A two-stage stratified random sampling technique was applied, and proper imputation methods were used to deal with non-responses. Grossing-up factors were derived scientifically.

Regarding government finance statistics, available data are quite comprehensive and include, in particular, operations of extra-budgetary funds, all defense related expenditures, and local government operations. The available data permit to measure output, intermediate consumption, fixed capital formation, and final consumption expenditure of government services. Estimates of government capital stock are not generated, which prevents the possibility of estimating the consumption of fixed capital applying the perpetual inventory method. The data used for the preliminary government estimates are provided on a cash basis by the MOF's Fiscal Programming Unit (UPF) and data on accrual basis are available 
approximately eleven months after the end of the reference year. This data are provided by the State General Accounting Office.

The administrative source data collected by the NSI is of uneven quality: it is very good for financial institutions, crude oil and natural gas, electricity, gas, and water supply. However, it is very weak for construction (low coverage of building permits from municipalities) and community, social, and personal services. Due to the need to protect confidentiality, aggregate data by economic activity are received from the Tax Authority. However, due to its high level of aggregation, it does not attend the NAD requirements. One of the problems to be resolved is the need to make consistent in practice the classification of taxpayers by economic activity with the national accounts classification of the same unit by economic activity.

In relation to price statistics, the following issues are noted: the CPI (base year 1990) has a basket of 332 products that represented approximately 90 percent of the households' final consumption expenditure in the base year. A new household survey was conducted in 2004 in order to update the base year of the CPI. The new basket will contain 508 products.

Price statistics for economic activities' output and products are available at varied levels of quality. The Construction Cost Index investigates costs by type of construction (e.g., residential building, infrastructure) and type of activity (e.g., installation). The Manufacturing Producer Price Index (base year 1990) has a fixed basket of 125 products, which represented 85 percent of the value added by the manufacturing industry in 1990 . The Import Unit Value index has a basket of approximately 830 products, based on an annual sample selection that is made every year, and takes into account the weight of the products in foreign trade. An export unit value index is also compiled by the NSI with a basket of 138 products and similar characteristics to the import unit value index. The NAD dose not, in general, apply these unit value indices, and uses instead international prices for imported machinery and other various imported products. Prices are also collected from ministries, producer's associations, and other sources. The NSI is revising the methodology of the foreign trade unit value indices with Swedish cooperation. ${ }^{3}$

The available price indices and prices for products are generally consistent with the variables being deflated in terms of price concept (except the mentioned unit values) and reference period; however, some of them have coverage problems.

With regard to sub-annual surveys and indicators that could be used for quarterly GDP compilation, the following is noted: the quarterly manufacture survey provides the inputs for

\footnotetext{
3 The present inconsistency between the national accounts implicit exports and imports price indices for goods and the revised foreign trade unit value indices will remain, among other reasons, for the inclusion of estimates of smuggling in the national accounts, which changes the prices and relative weights of different products as compared to the ones resulting from custom data, which are used in the compilation of unit value indices.
} 
two indices. A production volume index for the manufacturing industry and a manufacturing producer price index. Dissemination of the production volume index for the manufacturing industry was suspended in 2003; however, the index continued to be compiled and it was disseminated in the 2005 NSI Yearbook, covering also the period in which it was not disseminated. The NSI compiled also a monthly index of economic activity but this index had growing problems of coverage, for which reason it was discontinued in 2003 . The authorities are very much interested in a short term volume index covering most of the economic activities and are planning to resume compilation of the monthly index of economic activity.

As mentioned above, price statistics are weak for most economic outputs and products. The manufacture producer price index, based also on the above mentioned survey, has lost coverage due to its outdated 1990 fixed basket of products.

A survey conducted by NSI investigates employment, wages and compensations by economic activity, occupational group, and region. It is conducted every six months covering the last month of the corresponding semester (June and December). It had a quarterly periodicity until 2003, but due to the above referred budget reduction, its periodicity was reduced to a semester. The information on private labor market is complemented with a quarterly survey on public sector employment and wages.

The NSI and the CBB conduct quarterly surveys on entrepreneurial opinion. They are used by the NAD as part of the indicators employed in the assessment on the reliability of the quarterly GDP estimates.

The press and research papers are monitored for information on activities that need to be taken into account in the national accounts compilation process.

The available data are insufficient for compiling reliable quarterly GDP, as various indices with base year 1990 have lost coverage.

\section{Oil and gas activities}

Data for crude petroleum and natural gas are provided by YPFB. For exploration services, YPFB provides data on investment in shared-risk contracts (investment in operating expenditure) by enterprise and by region. The data are compiled on a monthly basis with a lag of two months after the end of the reference period. YPFB is the main source of information. Data for measuring intermediate consumption and added value can be obtained from YPFB; however, only output at current prices is used.

Recommendations: Update the establishment/enterprise directory and formulate a program of annual and quarterly economic surveys to support the regular compilation of the quarterly and annual national accounts. 


\subsubsection{Source data reasonably approximate the definitions, scope, classifications, valuation, and time of recording required}

Source data are broadly consistent with the definitions, scope, and classifications required for the national accounts. In general, data are also consistent with the time of recording, reference periods, and valuation of national accounts. Some exceptions are the activity classification applied by some data sources, which is still ISIC Rev. 2, while the one adopted for the national accounts is based on ISIC Rev 3 . However, a correspondence table permits compilers to reclassify the source data. Although some of the enterprises' financial statements correspond to the calendar year, for others the reporting period goes from April 1 to March 31; however, in the case of annual surveys, the questionnaires directly ask for calendar year data.

Data on agriculture production is recorded by the source as generated in the calendar year in which the harvest takes place. To estimate output on accrual basis, the costs of the most important crops are distributed through time by the NAD, using 1990 cost structures. New cost structures for the most important agricultural products have been investigated for the year 2000; they will be updated and then used in the new reference year.

As for government investment, the definition applied by the source data includes some components that have to be excluded by the NAD's compilers, in order to apply the GFCF concept used in national accounts.

Preliminary data for government statistics are valued on a cash basis and are used by the NAD to disseminate preliminary quarterly GDP estimates. Data on an accrual basis are available eleven months after the end of the reference year.

Recommendations: (1) Incorporate data for government expenditures on accrual basis in the semi definitive accounts, and (2) classify taxpayers by economic activity, with support of the NSI.

Oil and gas

Transactions are recorded on an accrual basis and coverage is very good.

\subsubsection{Source data are timely}

NSI's employees rigorously follow-up procedures to ensure the timely receipt of source data, including formal agreements signed with various institutions, which incorporate clauses related to the timing for supplying to the Institute the requested data. Respondents to NSI' surveys are made aware of the deadlines set for reporting. Very useful information for government expenditures, with a good coverage and on accrual basis, is provided eleven months after the end of the reference year. 


\section{Oil and gas activities and products}

Data of the enterprises engaged in oil and gas activities are provided by YPFB on a monthly basis, two months after the end of the reference period. Data on transport-related activities are provided by the relevant enterprise.

\subsection{Assessment of source data}

3.2.1 Source data-including censuses, sample surveys and administrative records-are routinely assessed, e.g., for coverage, sample error, response error, and nonsampling error; the results of the assessments are monitored and made available to guide statistical processes

The accuracy of the data from the NSI's surveys is well assessed, as editing procedures identify outliers and other atypical differences in periodic responses by individual survey units; also, extreme values are confirmed with respondents. The accuracy of other surveys and administrative sources are analyzed in the context of revisions. The national accounts revision cycle includes: preliminary, semi definitive, and definitive estimates. Data received in each phase of the cycle from the different sources are analyzed to check for temporal consistency and for consistency with other related source data. For example, the production of agriculture goods that are significant inputs of industrial activities are compared with the intermediate consumption/production of the corresponding industrial activity.

The national accounts dissemination cycle contemplates: (1) preliminary data to be posted on the website four months after the end of the reference year; (2) semi-definitive data is ready with a lago of 11 months, but disseminated with a lag of 16 months, together with the revised quarterly data; and (3) definitive data is ready with a lag of 24 months, but disseminated with a lag of 28 months, together with institutional sector accounts. However, annual GDP data for the past three years are still marked as preliminary. The same happens for the quarterly GDP data for these years, as the last ones are only revised on the occasion in which the annual data is revised.

\section{Oil and gas}

Source data are strictly controlled because of tax collection considerations. Oil is valued at international prices, collected in five markets. The price of gas is the result of negotiations between the government and the purchasing corporations.

\subsection{Statistical techniques}

\subsubsection{Data compilation employs sound statistical techniques to deal with data sources}

The NSI has established sound compilation procedures to minimize processing errors such as coding, editing, and tabulation errors. Adjustments to unit records are made only when clearly warranted. Procedures for imputation and adjustment for nonresponse in some 
establishment surveys are not adequate, as the procedure consists in repeating the response of the previous period.

Recommendation: Apply adequate imputation and adjustment procedures.

\subsubsection{Other statistical procedures (e.g., data adjustments and transformations, and statistical analysis) employ sound statistical techniques}

The national accounts cover part of the unobserved activities, including some illegal and informal activities. Among the illegal activities, estimates on the production and distribution of coca leaf are generated in the framework of a special Supply and Use Table (S\&U table), open to record the transactions of the "coca enclave" with the rest of the Bolivian economy and the rest of the world. The coca enclave is a special feature of the national accounts of Bolivia. For 1990, a joint study was conducted by the NSI and the Economic Policy and Analysis Unit (UDAPE) of the MOF, USAID, and the Bolivian Agricultural Reconversion Directorate in the coca leaf-producing zones, resulting in an input-output matrix for coca leaf and its derivatives. Also included are indirect estimates of some informal activities on the basis of the analysis of processing chains links, in which the relation between required selected inputs to generate some specific outputs are measured by making use of relevant 1990 technical coefficients. In this way, indirect estimates are made for informal activities in the production of meat, dairy, and bakery products among others. Also partial estimates on informal trade activities are included, as both, formal and informal trade are estimated on the basis of fixed distribution margin coefficients. Smuggling of exported and imported products are estimated, originating adjustments for underreporting and enclave transactions.

\section{Production approach procedures}

At the most disaggregated level, the supply of 233 products are estimated. At the aggregate level of the S\&U table, estimates are generated for the output of 35 activities and for 35 products. Output at constant prices is obtained by extrapolating base year values using output volume indices. Once output at constant prices is estimated, intermediate consumption and its product composition is obtained by applying fixed 1990 intermediate consumption/output coefficients, with gross value added obtained as a difference. Fix cells are not included in the intermediate consumption sub matrix of the table.

Aggregates at current prices are estimated by multiplying the constant price outputs and intermediate consumption products by corresponding price indices. Gross value added at current prices and constant prices are obtained by difference. In compiling value added, an excessive use is made of more than five years old fixed coefficients.

Output is measured for the economic activities at current and constant prices, using different methods on the basis of available information. For example, the value of agriculture products were estimated for the reference year on the basis of cultivated area, yield per hectare, and corresponding prices. Estimates at constant prices for consecutive years are obtained by extrapolation, using quantity indices of the main products. Three methods are used for 
manufacture activities: (1) the direct method, based on data from enterprises; (2) the processing chain method, using 1990 fixed technical coefficients; and (3) the expansion method, using average productivity by enterprise. In the case of electricity, gas, and water, data on amounts of electricity sold by type of users (household or industrial), volumes of gas sold, and cubic meters of water sold are multiplied by current year and 1990 year prices, respectively, in order to estimate the corresponding output at current and constant prices.

As for housing construction, use is made of the information contained in the permits granted by the municipalities, studies on the average duration of the work, the distribution of the costs through the duration of the work and the construction cost index. In the transport activity, where no direct data on services are available, use is made of the change rate in the number of automobiles on the road by department and by type of vehicle, assuming that the service provided by each type of vehicle in the reference year is constant through time at 1990 prices, but the coverage is very poor.

The techniques used to address some specific issues of GDP compilation are considered partially adequate: following the $1993 S N A$ recommendations, the output generated by owner-occupied dwellings is measured as the estimated rentals that tenants would pay for similar accommodation, while livestock reared for purposes of food is recorded as work in progress. However, changes in inventories are not adjusted for holding gains, because they are obtained as residuals, and consumption of fixed capital is not estimated since stocks of fixed capital, which would allow to apply the perpetual inventory method for this purpose, are not estimated.

Regarding procedures for compiling volume measures of GDP, the following issues are noted: as explained above, extrapolation by single volume indicators of output is used to estimate output at constant prices. Fixed 1990 coefficients are applied to derive value added. Taxes on products are estimated at constant prices by extrapolating the reference year taxes by a volume index of the supply of goods to domestic users (as a proxy to volume indices of sales subject to corresponding taxes). Output volume of trade margins is estimated by extrapolating the 1990 year trade margins with volume indices of sales or output, if only the later are available.

Financial intermediation services indirectly measured (FISIM) at constant prices are obtained by deflating current price values by CPI; however, a more adequate method could be applied.

In the framework of S\&U tables, from where the GDP aggregates of the expenditure approach are derived, the following aggregates are initially incorporated as independent estimates: government final consumption expenditure, GFCF, exports, and imports. Household final consumption expenditure at constant prices is obtained for each year by applying to the total supply of each of the 35 products the percentage represented by the households consumption in the 1990 table. Price indices taken from the CPI are applied to obtain current values. An excessive use is made of fixed coefficients more than five years old, which are applied to an aggregate that represents more than 60 percent of GDP. As for changes in inventories, they are obtained as residuals for each of the products, subject to the 
restriction that they cannot reach more than five percent of the total supply of the corresponding product. Once the total S\&U table is balanced, a set of consistent GDP aggregates by production and expenditure approaches is obtained.

Concerning classifications applied to final expenditure components, households final consumption expenditure is classified by purposes applying COICOP and also by products in the framework of the S\&U table. Government final consumption expenditure is not classified by function (i.e., by COFOG). Gross-fixed capital formation is compiled by type of assets (e.g., construction and machinery and equipment), but not by economic activities, since the commodity flow method is applied to estimate its value. Exports and imports are classified by product in the S\&U table. Changes in inventories, obtained at current and constant prices as residuals in the S\&U framework, become classified by the table's product classification.

Regarding the volume measures of the expenditure components of GDP, the following is noted: the household consumption implicit deflator is consistent with the CPI. Government final consumption expenditure is derived by deflating cost components of output for final use, with the exception of compensation of employees, which are extrapolated by a volume index of government employment.

Proper techniques are used to address specific issues of GDP compilation: government final expenditure excludes incidental sales; expenses of residents abroad are included in household final consumption expenditure and in imports; expenses of nonresidents in the economy are excluded from household final consumption expenditure and included in exports; expenditures on items that are considered stores of wealth (such as jewelry, works of art) are treated as recommended in the 1968 SNA: as intermediate consumption if acquired by producing units, and as final consumption if acquired by households.

Volume measures of the expenditure components of GDP are generated by using the S\&U table as a consistency tool. As noted above, the table is compiled initially at constant prices and, once balanced, a consistent set of expenditure GDP aggregates at constant prices is derived. The household consumption implicit deflator is in principle consistent with the CPI, although horizontal distribution fixed coefficients are applied to the total supply of each product. Differences may be registered due to changes in the relative importance of the supply of the different products. Government final consumption expenditure is derived by deflating cost components of output for final use, with the exception of value added, that is extrapolated by a quantity index of government employment. Imported components of GFCF, as well as exports and imports components are deflated by unit value indices of exports and imports, adjusted by an exchange rate index. Volume measures of changes in inventories are obtained as a difference between total supply and all other uses components, all them measured at constant prices.

To obtain one consistent temporal series combining series of annual and quarterly data, the Fernández multivariant method is applied. In the case of combining various economic activities series simultaneously, the Di Fonzo method is applied in order to reconcile them temporally and transversally. The method used for seasonal adjustment is signal detection 
applying the ARIMA modeling approach of Gomez and Maravall, processed with the TRAMO/SEATS and DEMETRA 2.0 program.

Decisions adopted in meetings of the CAN's “Government Experts on Quarterly National Accounts" group, are followed.

\section{Oil and gas}

Estimates at constant prices are obtained by multiplying output measured in fine metric tons by the price of the reference year 1990; intermediate consumption is estimated by applying input/output 1990 coefficients; and added value is obtained as a difference. Intermediate consumption at current prices is estimated by multiplying constant inputs values by corresponding price indices, and added value is obtained as a difference. However, information could be obtained on the components of the production account at current prices.

\subsection{Assessment and validation of intermediate data and statistical outputs}

\subsubsection{Intermediate results are validated against other information where applicable}

The NAD prepares each year an inventory of available source data, which could be used in the compilation process. The inventory permits to detect the data that, not being directly used, could nevertheless be taken into account to assess the reliability of the sources that enter in the compilation process, e.g., production data on the coca enclave are cross-checked with data on seizures by the Special Counternarcotics Force, production data are crosschecked with data on exports and input imports, and private final consumption by flow of goods is cross-checked with the consumption levels found through the households surveys. Population projections are also used as a reference.

In the case of construction, indirect indicators such as production and consumption of cement and the construction cost index are used to improve coverage, import of construction materials.

\subsubsection{Statistical discrepancies in intermediate data are assessed and investigated}

A systemic procedure to routinely assess the potential discrepancies in intermediate data has not been established. However, detected discrepancies in intermediate data are assessed, investigated, and reconciled, by using available information.

\subsubsection{Statistical discrepancies and other potential indicators of problems in statistical outputs are investigated}

The supply and use framework is used to investigate discrepancies and eliminate them in the process of balancing the table. As a result, GDP by production activities and GDP by expenditure components are consistent. GDP data could be validated against unofficial estimates that employ plausible assumptions and methods. 


\subsection{Revision studies}

3.5.1 Studies and analyses of revisions are carried out routinely and used internally to inform statistical processes (see also 4.3.3)

An ample analysis of revisions are carried out in each stage of the national accounts dissemination cycle. Studies of revisions are made routinely only for the construction activity. Documentation is prepared for this study.

\section{Serviceability}

\subsection{Periodicity and timeliness}

\subsubsection{Periodicity follows dissemination standards}

Periodicity of quarterly and annual GDP estimates follows GDDS recommendations and meet SDDS requirements.

\subsubsection{Timeliness follows dissemination standards}

The quarterly GDP estimates follow GDDS recommendations and meet SDDS requirements.

\subsection{Consistency}

\subsubsection{Statistics are consistent within the dataset}

Internal and intertemporal consistency of GDP figures are reached in the framework of balanced S\&U tables, estimated at current and constant prices. Some of the components are obtained as residuals, which ensures the consistency of GDP estimates by activity and expenditure approaches. The same is true for corresponding growth rates. GDP estimates at current prices, volume measures, and (implicit) deflators are consistent within the "value $=$ volume $\times$ price" framework.

Quarterly GDP estimates are consistent with annual GDP, as concepts, definition, and classification for compiling quarterly GDP estimates are the same as those used to compile annual estimates, and benchmarking techniques are applied.

\subsubsection{Statistics are consistent or reconcilable over a reasonable period of time}

Consistent time series data are available for annual estimates from 1988 to 2005. For quarterly GDP, data are consistent from 1988 to third quarter of 2006. The present series with reference period 1990 was reconstructed back to 1980 . 


\subsubsection{Statistics are consistent or reconcilable with those obtained through other data sources and/or statistical frameworks}

National accounts figures for government GFCF and final consumption are reconcilable with corresponding data produced by the UPF at cash basis and used, after adjustments, to pass from the data on investment to gross capital formation, as defined by the national accounts' for NSI's preliminary estimates. The same applies to the accrual basis data provided to the NSI by the MOF's Accounting Office which, once adjusted to national account requirements, are used in the revised estimates.

Also, data from the rest of the world account are generally reconcilable with BOP data for the same aggregates. Data for exports and imports of goods are provided by the NSI to the $\mathrm{CBB}$. They are adjusted by the BOP compilers, by excluding/including given flows. In connection to illegal activities, estimates are made for smuggling in the national accounts that are not included in the balance of payments.

Recommendation: Generate and disseminate bridge tables to reconcile NA with GFS and BOP data.

\subsection{Revision policy and practice}

\subsubsection{Revisions follow a regular and transparent schedule}

The national accounts revision and dissemination cycle is predetermined and reasonably stable from year to year. The cycle contemplates: (1) preliminary data to be posted in the website four months after the end of the reference year; (2) semi-definitive data is ready with a lag of eleven months, but disseminated with a lag of 16 months, together with the revised quarterly data; and (3) definitive data is ready with a lag of 24 months, but disseminated with a lag of 28 months together with institutional sector accounts. The main reasons underlying the established cycle are the timeliness of source data, the timing of revisions with related quarterly GDP and other datasets, and the timing for preparing important economic policy documents. Neither the revision cycle nor the reasons taken into account when establishing it have been made known to the public. Partial information on the cycle is included in the advance dissemination calendar, posted on the CBB website. Documentation of revisions is prepared but not disseminated to the public.

Recommendation: Provide to the public information on the revision cycle, reasons for establishing it, and documentation on revisions.

\subsubsection{Preliminary and/or revised data are clearly identified}

The preliminary nature of the disseminated data is clearly noted by a (p), but users are not informed whether the rest of the disseminated data have been revised. Annual GDP data for the last three years are still marked as preliminary and the same happens for the quarterly 
GDP data for these years, as the last ones are only revised on the occasion in which the annual data are revised.

Recommendation: At the time of dissemination, identify also the data that have been revised and become semi definitive or definitive.

\subsubsection{Studies and analyses of revisions are made public (see also 3.5.1)}

Analysis of differences between the revised semi definitive and preliminary data is made for major aggregates to allow for an assessment of the reliability of the preliminary data. The same applies for the comparison between definitive and semi definitive data. Results of the analyses are documented but not disseminated.

Recommendation: Disseminate the results of analyses of revisions, to allow for an assessment of the reliability of the disseminated data.

\section{Accessibility}

\subsection{Data accessibility}

\subsubsection{Statistics are presented in a way that facilitates proper interpretation and meaningful comparisons (layout and clarity of text, tables, and charts)}

National accounts are disseminated in a clear manner, in documents that include analysis of the main results, tables and charts, as well as explanations on data sources main limitations Also, time series starting from 1988 are easily accessed in the NSI website.

\subsubsection{Dissemination media and format are adequate}

National accounts data are disseminated in ways that facilitate the media to redisseminate the information, e.g., through press releases, that are posted on the website.

Oil and gas activities and products

Aggregate data for oil, derived products and natural gas are disseminated in the corresponding product rows and economic activity columns of the S\&U table.

\subsubsection{Statistics are released on a preannounced schedule}

An advance release calendar for annual and quarterly GDP data is posted on the CBB website. The release of the national accounts data follows the preannounced schedule. 


\subsubsection{Statistics are made available to all users at the same time}

A government policy advisory committee is provided with data that may or may not have been disseminated to the public. However, this practice does not affect the prescheduled dissemination of data.

\subsubsection{Statistics not routinely disseminated are made available upon request}

In addition to the statistics routinely disseminated, other general statistics are made available to users upon request, subject to the protection of the confidentiality of individual data. The public is not made aware of the availability of additional statistics and of the procedures for obtaining them.

Recommendation: Make the public aware of the availability of additional statistics, and of the procedures for obtaining them.

\subsection{Metadata accessibility}

5.2.1 Documentation on concepts, scope, classifications, basis of recording, data sources, and statistical techniques is available, and differences from internationally accepted standards, guidelines, or good practices are annotated

The National Accounts Bulletin 1988-1997, issued in February 2001, describes source data and compilation methods. However, it contains mainly a description on concepts and definitions.

Metadata posted on the NSI website for national accounts include documents on sources used and methods applied to compile, among others: institutional sector accounts, quarterly GDP at current and constant prices, seasonally adjusted quarterly GDP figures, regional GDP, and input-output tables. Also posted are metadata on various censuses and economic surveys; statistics on economic activities such as construction, energy, transport, etc, as well as on the main price and volume indicators generated by the NSI. Most of the statistics and indicators covered by these metadata are used as inputs in compiling the national accounts. The metadata are readily accessible through the website, where they are posted together in a special section on metadata.

GDDS metadata posted on the IMF website is being updated and reformulated with a view to preparing the subscription to the SDDS.

\subsubsection{Levels of detail are adapted to the needs of the intended audience}

Some of the above mentioned metadata are quite general and useful for a wider public, but others are intended for more specialized users. The National Accounts Bulletin 1988-1997, referred above, and more recent national accounts publications may be accessed. The Bulletin may be accessed contacting the NSI's Customer Service Unit. More general information 
(e.g., a brochure) about the national accounts statistics has not been prepared due mainly to financial restrictions. Access to national accounts statistics and metadata is very easy on the NSI website.

\subsection{Assistance to users}

\subsubsection{Contact points for each subject field are publicized}

The Institute's Customer Service Unit gives prompt and efficient assistance to users. Contact points with the NAD are not directly provided; nevertheless, they are found in national accounts metadata on the website where names, phone numbers, and e-mail addresses are given. The information on contact points is updated when the metadata is updated.

Recommendation: Provide direct contact points for national accounts on the NSI website.

\subsubsection{Catalogs of publications, documents, and other services, including information on any charges, are widely available}

A virtual library and a catalog of the NSI's publications and other documents are available on the website and in the Central Library. Photocopies and printouts of tables are available to the public upon request. The public is invited to subscribe to a distribution list free of charge, in order to receive information by e-mail. A 2006 catalog of publications is available. The Customer Service Unit gives information on prices and provides assistance in placing orders. Prices charged cover only the publications cost. 
Table 1. Bolivia: Data Quality Assessment Framework (July 2003): Summary of Results for National Accounts

(Compiling Agency: National Statistic Institute)

\begin{tabular}{|c|c|c|c|c|c|c|c|}
\hline \multicolumn{8}{|c|}{$\begin{array}{l}\text { Key to symbols: NA = Not Applicable; } \mathrm{O}=\text { Practice Observed; LO = Practice Largely Observed; LNO = Practice Largely Not Observed; NO = Practice Not Observed; SDDS = Complies with SDDS } \\
\text { Criteria }\end{array}$} \\
\hline \multirow{2}{*}{ Element } & \multirow{2}{*}{ NA } & \multicolumn{4}{|c|}{ Assessment } & \multirow{2}{*}{ Comments on Assessment } & \multirow{2}{*}{ Plans for Improvement } \\
\hline & & $\mathrm{O}$ & $\mathrm{LO}$ & LNO & NO & & \\
\hline \multicolumn{8}{|l|}{ 0. $\quad$ Prerequisites of quality } \\
\hline 0.1 Legal and institutional environment & & & $\mathrm{X}$ & & & $\begin{array}{l}\text { DL } 14100 \text { has partially lost its relevance } \\
\text { due to the limited legal power of a decree } \\
\text { vis- } \dot{a} \text {-vis a law. The same problem exists } \\
\text { in relation to decree } 21855 \text {, which } \\
\text { transferred the compilation of the national } \\
\text { accounts from the CBB to NSI. Data } \\
\text { sharing and coordination with the CBB } \\
\text { and the MOF could be improved. }\end{array}$ & $\begin{array}{l}\text { The NSI is giving high priority to the } \\
\text { approval of the new Statistical Law. } \\
\text { Data sharing and coordination with the } \\
\text { CBB and the MOF will be reinforced. }\end{array}$ \\
\hline 0.2 Resources & & & $\mathrm{X}$ & & & $\begin{array}{l}\text { Funding is required for conducting } \\
\text { important economic surveys that were } \\
\text { suspended in the last years due to } \\
\text { budgetary restrictions; and for } \\
\text { establishing an adequate data collection } \\
\text { program for national accounts. }\end{array}$ & $\begin{array}{l}\text { Efforts are in place to obtain resources to } \\
\text { establish an adequate data collection } \\
\text { program for quarterly and annual national } \\
\text { accounts. }\end{array}$ \\
\hline 0.3 Relevance & & & $\mathrm{X}$ & & & $\begin{array}{l}\text { Structured and periodic processes of } \\
\text { consultation with main users are needed, } \\
\text { in order to review the usefulness of the } \\
\text { national accounts and to identify new data } \\
\text { requirements. }\end{array}$ & $\begin{array}{l}\text { Adequate mechanisms will be defined and } \\
\text { established (medium-term). }\end{array}$ \\
\hline 0.4 Other quality management & & $\mathrm{X}$ & & & & & \\
\hline \multicolumn{8}{|l|}{ 1. Assurances of integrity } \\
\hline 1.1 Professionalism & & $\mathrm{X}$ & & & & & \\
\hline 1.2 Transparency & & & $\mathrm{X}$ & & & $\begin{array}{l}\text { Internal governmental access to statistics } \\
\text { prior to their release to the public is made } \\
\text { public on the websites of the CBB and the } \\
\text { IMF, but not of the NSI. }\end{array}$ & $\begin{array}{l}\text { Government's prior access to statistics } \\
\text { will be made public on the NSI website } \\
\text { (short-term). }\end{array}$ \\
\hline 1.3 Ethical standards & & $\mathrm{X}$ & & & & & \\
\hline
\end{tabular}


Table 1. Bolivia: Data Quality Assessment Framework (July 2003): Summary of Results for National Accounts (Compiling Agency: National Statistic Institute)

\begin{tabular}{|c|c|c|c|c|c|c|c|}
\hline \multirow{2}{*}{ Element } & \multirow{2}{*}{ NA } & \multicolumn{4}{|c|}{ Assessment } & \multirow{2}{*}{ Comments on Assessment } & \multirow{2}{*}{ Plans for Improvement } \\
\hline & & $\mathrm{O}$ & $\mathrm{LO}$ & LNO & $\mathrm{NO}$ & & \\
\hline \multicolumn{8}{|l|}{ 2. Methodological soundness } \\
\hline 2.1 Concepts and definitions & & & $\mathrm{X}$ & & & $\begin{array}{l}\text { The national accounts are compiled using } \\
\text { mainly the } 1968 S N A \text { as a conceptual } \\
\text { framework. However, important features } \\
\text { of the } 1993 S N A \text { have been incorporated }\end{array}$ & $\begin{array}{l}\text { A project is being implemented in order to } \\
\text { more widely apply the } 1993 S N A \text { and to } \\
\text { actualize the national accounts reference } \\
\text { year. }\end{array}$ \\
\hline 2.2 Scope & & & $\mathrm{X}$ & & & $\begin{array}{l}\text { Institutional sector accounts are compiled } \\
\text { only up to the capital account. The } \\
\text { NPISH sector is not investigated. }\end{array}$ & \\
\hline 2.3 Classification/sectorization & & & $\mathrm{X}$ & & & $\begin{array}{l}\text { Government expenditures are not } \\
\text { classified by functions. }\end{array}$ & $\begin{array}{l}\text { The COFOG classification will be } \\
\text { adopted to classify government } \\
\text { expenditures by functions (medium-term). }\end{array}$ \\
\hline 2.4 Basis for recording & & $\mathrm{X}$ & & & & & \\
\hline
\end{tabular}


Table 1. Bolivia: Data Quality Assessment Framework (July 2003): Summary of Results for National Accounts (Compiling Agency: National Statistic Institute)

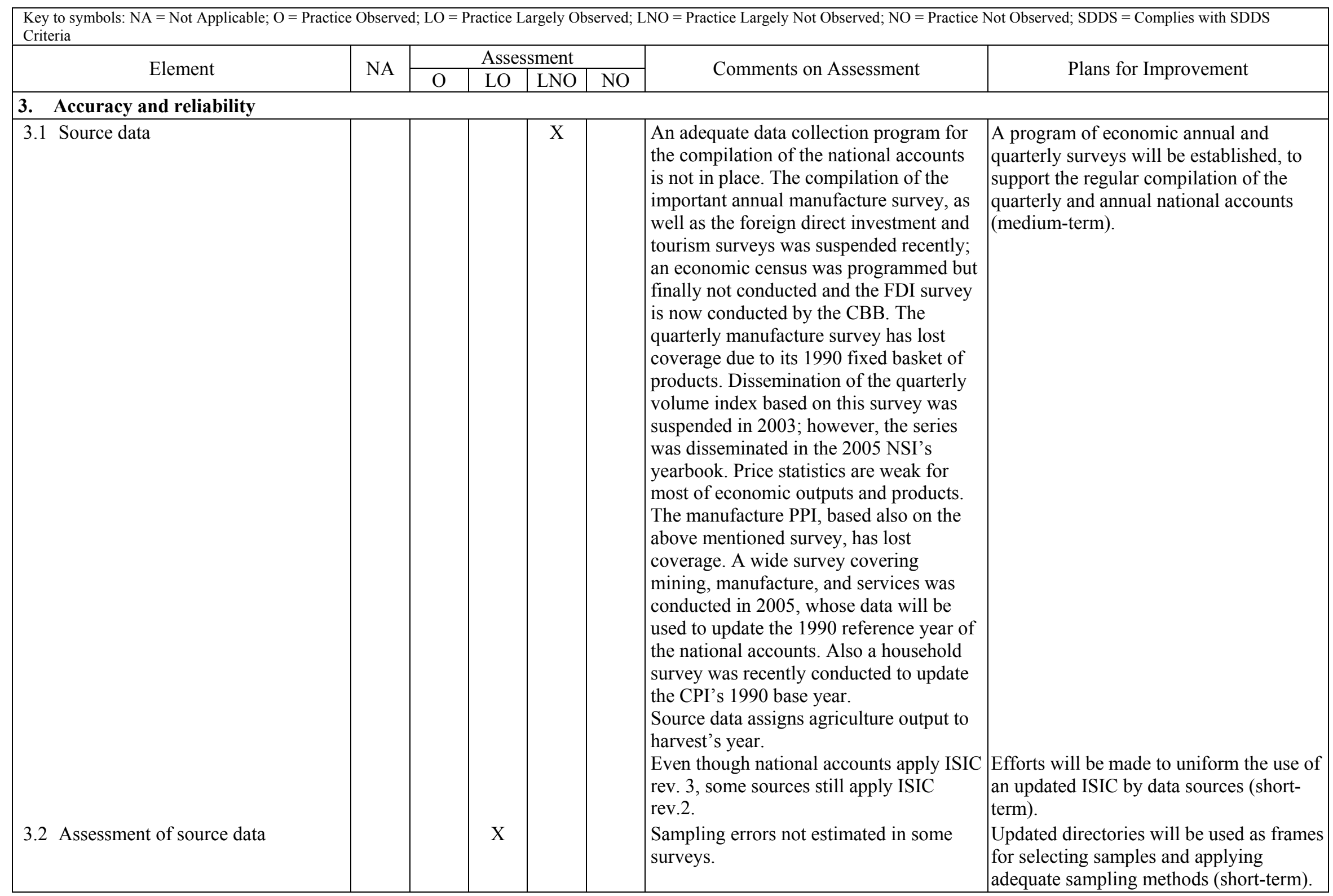


Table 1. Bolivia: Data Quality Assessment Framework (July 2003): Summary of Results for National Accounts (Compiling Agency: National Statistic Institute)

\begin{tabular}{|c|c|c|c|c|c|c|c|}
\hline \multicolumn{8}{|c|}{$\begin{array}{l}\text { Key to symbols: NA = Not Applicable; } \mathrm{O}=\text { Practice Observed; LO = Practice Largely Observed; LNO = Practice Largely Not Observed; NO = Practice Not Observed; SDDS = Complies with SDDS } \\
\text { Criteria }\end{array}$} \\
\hline \multirow{2}{*}{ Element } & \multirow{2}{*}{ NA } & \multicolumn{4}{|c|}{ Assessment } & \multirow{2}{*}{ Comments on Assessment } & \multirow{2}{*}{ Plans for Improvement } \\
\hline & & $\mathrm{O}$ & $\mathrm{LO}$ & LNO & $\mathrm{NO}$ & & \\
\hline 3.3 Statistical techniques & & & & $\mathrm{X}$ & & $\begin{array}{l}\text { Indirect estimates for partial informal } \\
\text { activities in agriculture, manufacture and } \\
\text { related trade could be extended to other } \\
\text { activities. Reference year } 1990 \text { is } \\
\text { outdated; however, a project for updating } \\
\text { it is being implemented. Due mainly to } \\
\text { lack of source data, excessive use is made } \\
\text { of fixed } 1990 \text { input-output coefficients; } \\
\text { vector of households final consumption at } \\
\text { constant prices estimated via horizontal } \\
\text { fixed coefficients in use side of S\&U } \\
\text { table, no fixed cells in S\&U table, and } \\
\text { changes in inventories obtained as } \\
\text { residuals. Pension funds treatment and } \\
\text { FISIM estimation at constant prices could } \\
\text { be improved. }\end{array}$ & $\begin{array}{l}\text { The possibility of using the households } \\
\text { survey and other available sources, to } \\
\text { estimate the participation of the informal } \\
\text { sector and changes in employment and } \\
\text { income generation, will be assessed } \\
\text { (short-term). } \\
\text { Fixed cells in S\&U table will be } \\
\text { incorporated, where available data permits } \\
\text { (short-term). }\end{array}$ \\
\hline $\begin{array}{l}\text { 3.4 Assessment and validation of inter- } \\
\text { mediate data and statistical outputs }\end{array}$ & & $\mathrm{X}$ & & & & 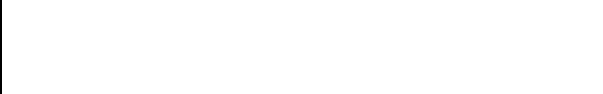 & \\
\hline 3.5 Revision studies & & & $\mathrm{X}$ & & & $\begin{array}{l}\text { Although analysis of revisions are } \\
\text { routinely carried out for all activities, } \\
\text { studies of revisions are made only for the } \\
\text { construction activity. Documentation is } \\
\text { prepared for this study. }\end{array}$ & $\begin{array}{l}\text { Studies of revisions will be extended to } \\
\text { other activities (short-term). }\end{array}$ \\
\hline
\end{tabular}


Table 1. Bolivia: Data Quality Assessment Framework (February 2007): Summary of Results for National Accounts (Compiling Agency: National Statistic Institute)

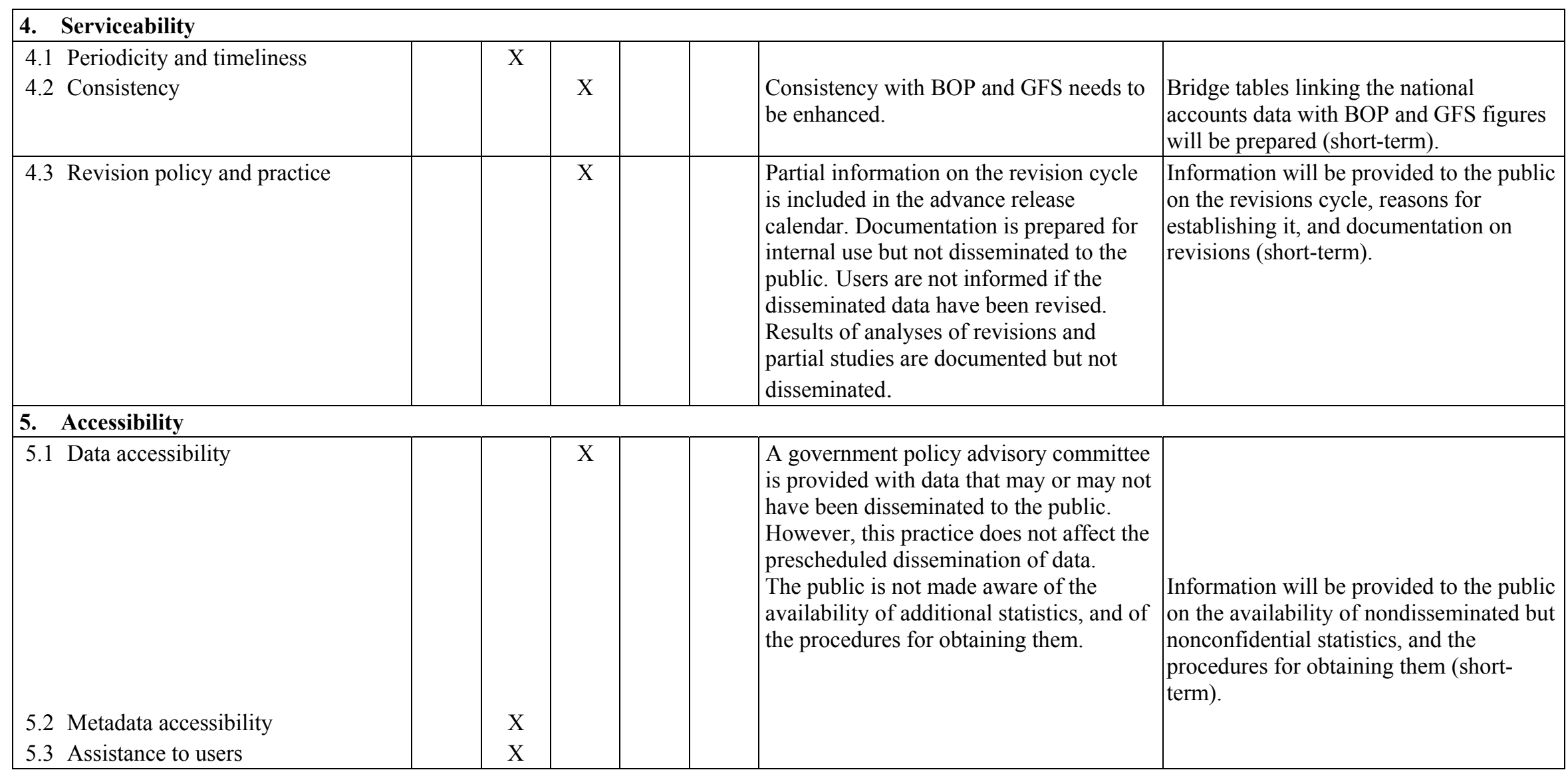




\section{Price Statistics (Consumer Price Index)}

\section{Prerequisites of quality}

\subsection{Legal and institutional environment}

\subsubsection{The responsibility for collecting, processing, and disseminating the statistics is clearly specified}

The price statistics of Bolivia are compiled and disseminated by the National Statistics Institute (NSI), which has been responsible for compiling the consumer price index (CPI) since 1966. Decree-Law (DL) 14100 of November 5, 1976 created the National Statistical Information System (SNIE). Within the SNIE, the NSI is a decentralized entity with administrative and operational autonomy. Supreme Decree 24009 established that it was to be accountable to and supervised by the Ministry of Finance, serve as the executive and technical organ of the SNIE, and be responsible for managing, planning, implementing, monitoring, and coordinating statistical activities. This situation was confirmed by Supreme Decrees 26772, 26973, and 27732.

Chapter III, Article 8(c) of Decree-Law 14100 states that the NSI has the following functions: "To compile, prepare, analyze, and publish the statistics indicated in the National Operating Plan and other data necessary for the study of particular aspects of national activities." Based on the Constitution and on the above mentioned legal provisions, the NSI drew up the Strategic Institutional Plan 2005-2009, which includes in its matrix of statistical products: (1) the CPI, (2) the producer price index (PPI), (3) the construction cost index, and (4) salaries and remuneration.

\subsubsection{Data sharing and coordination among data-producing agencies are adequate}

Chapter III, Article 8(b) of DL 14100 states that the NSI has the task of coordinating and monitoring the statistical activities of the institutions belonging to the SNIE and ensuring implementation of the National Operating Plan for Statistical Data. Articles 10 and 11 of the same Chapter provide for the establishment of Technical Committees on Statistical Coordination with the participation of the institutions related to the SNIE and established by the NSI, which are required, among other things, to collaborate in drawing up the National Operating Plan for Statistical Data and promote the holding of meetings and conferences on statistics, and the systemization and coordination of national statistical activities through the NSI. In practice, committees of this type are set up to implement interinstitutional studies and agreements, but do not function on a permanent basis.

\subsubsection{Individual reporters' data are to be kept confidential and used for statistical purposes only}

Chapter II, Article 21 of DL 14100 states that data and information obtained by the SNIE are confidential, may be used only for statistical purposes, and may not be revealed in 
individualized form. Moreover, requests from administrative and judicial bodies for individualized information are not entertained. Article 22 of the same chapter states that "to guarantee statistical secrecy, all institutions belonging to the system and their officials are prohibited from providing or supplying data in violation of the provisions of the previous article." Access to individual data is restricted to the specialists responsible for their compilation.

Statistics are published in aggregated tables, with no identification of individual reporting units and establishments. Once the information has been transcribed, the related report forms are filed for a period of approximately two years, after which they are moved to NSI central archives.

\subsubsection{Statistical reporting is ensured through legal mandate and/or measures to encourage response}

Title V, Chapter I, Article 15 of DL 14100, which refers to data provision, states that all individuals and legal entities in the country, resident and nonresident, must, within the prescribed period, submit any data and information related by nature and purpose to the activities of the system and required by the NSI. Article 16 states that all individuals and legal entities must provide the NSI with a copy of their work, studies, charts, plans, sketches, photographs, etc. that may be useful for any study or research undertaken by the system as part of its activities. Violations are punished in accordance with DL 14100 and with such other laws as are duly determined by the Council at the request of the NSI. The implementation of this decree-law with respect to disclosure is not mandatory, as the person reporting may refuse to participate in a given survey or to disclose some data.

At the outset of the Household Budget Survey (HBS) 1990 and the Continuous Household Survey (CHS) 2003/2004, contact was established with the selected dwellings, and a direct interview held to explain the objectives of the survey and encourage voluntary cooperation. In the event of a refusal, the supervisor made a special visit to try and obtain the cooperation of the members of the household and, if they persisted in their refusal, a substitution was made from a sample of replacement dwellings designated for the purpose.

In the HBS (1990) and the CHS (2003/2004) two types of survey instrument were used: questionnaires for direct questions to interviewees, and notebooks for capturing information on daily spending both of the head of the household and of the members who manage money on his or her behalf. In preparing the questionnaires and notebooks, care was taken to ensure that they were simple for the price collector to manage and master, and of limited extent so as not to tire the reporter.

The price collection forms are adapted to each type of establishment so that they include up to six products (goods or services) described in full detail (name, characteristics, packaging, form, color, weight, brand, origin, and unit of measurement), with an effort made to generate complete information that does not raise doubts on the part of the price collector when the information is collected. 
In consumer price surveys, the price collector acts as a customer and does not identify himself or herself as an NSI official, except for some services. The survey plan rotates the price collectors so that they visit the same retail establishment every six months.

\section{$0.2 \quad$ Resources}

\subsubsection{Staff, facilities, computing resources, and financing are commensurate with statistical programs}

The Directorate of Statistics and Economic Indicators (DEIE) is part of the Executive Directorate of the NSI and comprises three units: (1) External Sector Records, Statistics, and Indicators, (2) Price Records, Statistics, and Indicators (UREIP), and (3) Economic Activity Statistics and Indicators (UEIAE).

The UREIP is responsible for compiling indicators of producer prices, consumer prices, construction costs, average wages, salaries, and employment. It has a head of unit, six fulltime specialists, and 25 regular employees compiling the CPI at the national level: one national manager, one national expert, two general supervisors (Cochabamba and Santa Cruz), and 21 technical field operatives — La Paz y Alto (9), Cochabamba (6), and Santa Cruz (6).

The technical field operatives compile price and rent surveys, and transcribe the data. The supervisors verify the variations in prices, present periodic reports on the price behavior of the main products, and forward the information to the central office. The national expert coordinates the compilation activity with the regional offices and analyzes the information gathered and transcribed. The national manager formulates the study methodologies, and coordinates and plans the CPI compilation activities from information capture to presentation of the indicator.

For compilation of the new CPI, a special team was recruited for a period of a year. This team has 86 members (three technical specialists, nine regional managers, 11 supervisors, 43 price collectors, 10 transcribers, and 10 drivers). The supervisors and specialists took part in seminars and workshops hosted by the Economic Commission for Latin America and the Caribbean (ECLAC) and the National Statistics Institute of Spain, especially on themes related to compilation and harmonization of the CPI.

Between 2005 and the first half of 2006, the UREIP took care of the special requirements of the International Comparison Program (ICP), for which it received technical assistance from representatives of Canada's National Statistical Agency and ECLAC, which helped to improve the professionalism of its experts.

The compensation of CPI personnel is based on the salary scale of civil servants. The average length of service for specialists is more than ten years and six years for field workers. 
Computer resources have recently been updated with the purchase of ten computers for compiling the new CPI. This equipment has sufficient capacity to handle the databases. The processing system for the CPI was developed on Microsoft's Windows 2000 platform, on the basis of the licenses available and the rules on use drawn up by the NSI.

The CPI application (base year 1991) was developed using the Visual Basic Professional version 6.0, and Access 2000 was used as the database. The entire application consists specifically of three installable modules: (1) the CPI system strictly speaking, (2) the data export and import module, and (3) the CPI tools module. This system allows data to be entered periodically and details to be updated by reporter, queries to be made directly on screen, reports to be printed, and data to be migrated to Excel. All options can be seen through messages and screens. Supervisors and experts were all trained to operate the system, including all its modules and options. Technical field operatives were trained to key in the information.

There are appropriate office environments and equipment allocated in each of the towns where the CPI is conducted. However, the supervisors and technical field operatives in the regional offices do not have access to e-mail, which limits coordination activities.

The number of vehicles assigned to price collection work in each of the towns is sufficient to transport personnel to the various commercial zones: La Paz y Alto (2), Cochabamba (1), and Santa Cruz (1). However, no regular budget is allocated for maintenance of the vehicles.

Budget planning is subject to the NSI's Annual Operating Plan, and the sum allocated for the CPI (base year 1991) has been kept constant in recent years. The Plan allows for coverage of the salary expenses of full-time personnel and contractors as well as regular expenses, such as fuel, communications, courier services, and office supplies. There is no budget allocation for the systematic supervision of data collection in the country's hinterland.

For the compilation of the new CPI, external financing has been received for administrative costs and human resource recruitment and for the purchase of computer equipment.

Recommendations: (1) Increase the staff of the UREIP and raise the allocation of budgetary resources to maintain the improvements planned for the new CPI (wider geographical coverage, expanded basket, and systematic control of the quality of field operations, development of a new processing system); and (2) assess the methodological improvements proposed for proper planning of technological and programming resources.

\subsubsection{Measures to ensure efficient use of resources are implemented}

The performance of CPI personnel is evaluated every six months, coordinated by the human resource unit and includes the participation of the Director of the DEIE, the head of the UREIP, and the Indicator manager. The following competences are evaluated: analytical capacity, communication, performance under pressure, specific abilities, work organization, interpersonal skills, and quality of service. The Administrative Services Directorate carries 
out half-yearly assessments of UREIP progress on the tasks assigned to it for compilation of the CPI, in accordance with the Annual Operating Plan.

\section{$0.3 \quad$ Relevance}

\subsubsection{The relevance and practical utility of existing statistics in meeting users' needs are monitored}

The CPI is the official inflation indicator in Bolivia and it is widely used in the economic, legal, and social areas, specifically as a deflator of the national accounts system as well as in the updating of social benefits and salary negotiations. The CBB uses it for constructing the Housing Promotion Unit (UFV) and calculating underlying inflation.

While a formal mechanism has not been established, with the participation of various economic sectors, for discussions on the requirements for price information, once or twice a year seminars are held for academic economists on CPI themes: calculation methodology, information gathering, and especially its application and interpretation. The importance and scope of the CPI may also be made known through activities such as seminars for journalists and audiovisual and press interviews.

The Executive Directorate of the NSI has currently launched a series of meetings to inform government institutions about the change of base year and the updating of weights in the CPI, as well as the planned methodological improvements.

Recommendations: (1) Organize a formal mechanism, with the participation of users, to consult them on their information needs, clear up doubts regarding the interpretations, applications, and limits of the CPI, and inform them of any methodological improvements incorporated in the indicator and any major changes in the basket of products and their weights; and (2) publish on the NSI website the methodological document containing the entire project, including the HBS 2003-2004, and links between series at the same time the new indicator series is launched.

\section{$0.4 \quad$ Other quality management}

\subsubsection{Processes are in place to focus on quality}

In the Strategic Institutional Plan 2005-2009, the NSI defined its mission in the following terms: "To produce and disseminate useful, timely, and reliable official statistics on the national situation," and identified the core principles of service, integrity, quality, confidentiality, and organization. These principles are diffused throughout NSI documents and publications and the orientation programs for persons joining the institution. They are also emphasized in the methodological documents and manuals for price collectors and supervisors of both the HBS and the CPI. 


\subsubsection{Processes are in place to monitor the quality of the statistical program}

The technical staff of the UREIP established processes for monitoring the quality of the CPI in the various stages of its preparation: (1) technical field operatives produce initial consistency checks by reviewing the prices of products in various markets, (2) the supervisor identifies price increases or reductions and checks that they are not due to changes in the specification of the product, (3) the regional manager analyzes the history of prices by product and reporter and compares them with information received from other reporters and with a formula of reference prices surveyed in randomly selected shops in the area, and (4) the price specialist carries out a similar validation and supplements it with analysis of changes and impacts by product.

Owing to budgetary constraints, there are no regular programs to monitor the quality of domestic price collection work.

For the methodological development of the CPI (base year 1991) two outside consultants provided technical assistance with the procedures for consumer price collection and processing. For the change of base and updating of weights for the CPI, it is planned to engage an international advisor during 2007.

Recommendations: (1) Assess the advantages and disadvantages of acting as a customer when collecting CPI prices, bearing in mind that this collection model makes it difficult to carry out subsequent verification of atypical prices and supervision of the price collectors activities; and (2) design a processing system that facilitates monitoring of missing prices by product/establishment, and the reasons thereof, and keep a record of those reasons, to use this information in the process of continuous CPI quality improvement.

\subsubsection{Processes are in place to deal with quality considerations in planning the statistical program}

The NSI authorities are aware of the need to improve the quality of the CPI and that to do so it will be necessary to update the basket and weights, which relate to 1991, and to expand the geographical coverage to include all the country's main towns. Accordingly, the following work plan has been developed: (1) during 2003-2004, as part of the Program for the Improvement of Surveys and the MECOVI, and with the support of ECLAC, the Continuous Household Survey was conducted to update the basket and weights for the CPI, using as reference households' income and expenditure, with geographical coverage of all the country's main towns, using the Classification of Individual Consumption by Purpose (COICOP), and following the concepts and definitions of household consumption expenditure described in the 1993 SNA; (2) during 2005-2006, the survey of specifications was carried out to select the specific goods and services by town; (3) during 2006-2007, prices are being captured to generate the average prices for the base period; and (4) in 2007, the rental survey will begin. 
The new CPI will use base year 2007, and methodological improvements are planned, basically in geographical coverage, expansion of the basket, and calculation of the geometric mean of the price relatives. Similarly, improvements will be included in the design of databases and processing programs for the indicator.

This improvement program will be implemented with financing from the Steering Committee of the Bolivia-Canada Central Social Fund, set by the Canadian International Development Agency and the Vice Ministry of Public Investment and External Financing.

\section{Assurances of integrity}

\subsection{Professionalism}

\subsubsection{Statistics are produced on an impartial basis}

The NSI is an autonomous entity responsible for compiling and presenting the CPI. The criteria it applies in carrying out these activities are strictly technical, and compilers are independent in their selection of data sources and processing methods, without interference from other public or private entities. The Executive Director of the NSI is the person authorized to present the CPI.

Title VII, Chapter II, Article 26 of DL 14100 states that officials assigned to statistical work in all SNIE institutions are statistical personnel and therefore governed by the relevant provisions of the Decree-Laws on the National System of Administrative Careers and Personnel.

The specialists compiling the CPI have 10-15 years' experience each and have received training in statistics through courses taught in the country. In addition, they have followed specialized international courses in price indicators provided by organizations such as Spain's National Statistics Institute, ECLAC, and the Andean Community of Nations (CAN).

\subsubsection{Choices of sources and statistical techniques as well as decisions about dissemination are informed solely by statistical considerations}

The statistical methods and selection of sources, as well as the methodologies, concepts, and statistical procedures used in compiling the CPI are in accordance with international standards, and were adopted by the NSI on the basis of strictly statistical considerations. Similarly, results are disseminated solely on the basis of statistical considerations, and the methodological documentation has been prepared and made available to the public. 


\subsubsection{The appropriate statistical entity is entitled to comment on erroneous interpretation and misuse of statistics}

The NSI closely monitors media coverage of its data and, in the event of erroneous interpretations, provides timely public clarifications, using the various means available to it.

\subsection{Transparency}

\subsubsection{The terms and conditions under which statistics are collected, processed, and disseminated are available to the public}

The NSI website includes a section on its economic research and publications, including the major methodological aspects relating to compilation of the CPI (base year 1991) and HBS 1990. The methodology and results of the CHS 2003-2004 have recently been published and are available on the NSI website and in its library. The methodological documents include a special section on data security and integrity, explaining the independent and confidential manner in which both the CPI and surveys are prepared, protected by Article 21 of DL 14100 of the SNIE.

\subsubsection{Internal governmental access to statistics prior to their release is publicly identified}

CPI estimates, both preliminary and final, are presented to the Macroeconomic Group (composed of the President of the CBB, the Minister of Development Planning, the Minister of Finance, the Executive Directors of the NSI, the Economic Policy Analysis Unit (UDAPE), the Fiscal Programming Unit (UPF), and the Fiscal Analysis Network (RAF), which meets periodically to monitor macroeconomic developments. This may give rise, in some cases, to prior access to information, but it does not interfere with its public dissemination. This practice is openly identified in the metadata published on the websites of the $\mathrm{CBB}$ and the IMF.

The CPI methodological document expressly states that the indicator is published on the first business day of each month and indicates in which publications. The publication dates are given in the Calendario Anual de Estadísticas Económicas (Annual Release Calendar of Economic Statistics) published on the CBB website.

Recommendation: Include the Calendario Anual de Estadisticas Económicas on the NSI website.

\subsubsection{Products of statistical agencies/units are clearly identified as such}

Title V, Chapter I, Article 20 of DL 14100 states that statistical publications must indicate the original sources of the information they contain. Methodological documents, tables and graphs, as well as Actualidades Estadísticas (Statistical Bulletin) and press releases published by the NSI in hardcopy or electronic form, bear the NSI's name and logo. The NSI authorizes 
full or partial reproduction of the information in its publications, provided that the data source is cited.

\subsubsection{Advanced notice is given of major changes in methodology, source data, and statistical techniques}

At the beginning of the current CPI series (base year 1991), the importance and scope of the CPI were publicized through activities such as seminars for journalists and interviews in the audiovisual and print media. The methodological document published on the website of the NSI provides general information regarding the methodological improvements planned for the change of base of the CPI.

\subsection{Ethical standards}

\subsubsection{Guidelines for staff behavior are in place and are well known to the staff}

The by-laws governing NSI personnel spell out the regulations on the relationships of public servants; state the rights, duties, prohibitions, and incompatibilities pertinent to them; and provide for disciplinary measures to be taken against any public servant violating the rules. NSI personnel are informed of these by-laws during the orientation they receive when joining the institution. Moreover, the methodological documents and manuals for price collectors and supervisors in the various surveys emphasize the legal principles requiring personnel to treat all information with discretion and confidentiality.

\section{Methodological soundness}

\subsection{Concepts and definitions}

\subsubsection{The overall structure in terms of concepts and definitions follows internationally accepted standards, guidelines, or good practices}

Both the conceptual framework for the HBS 1990 and the basket of goods and services and weights for the CPI (base year 1991) adhere to the concepts and definitions of household consumer spending of $1968 S N A$, as well as the recommendations of the International Labour Organisation (ILO).

The concepts and definitions used in the CPI generally follow internationally accepted standards, in accordance with the Consumer Price Index Manual (2004).

The prices collected are the market prices paid by households at the various points of sale where they engage in transactions and include all the taxes levied on the goods and services traded.

The basket of goods and services for the CPI (base year 1991) is sufficiently disaggregated and allows for price trends to be monitored with respect to nine chapters, 25 groups, 
54 subgroups, and 332 goods and services differentiated for each of the towns, which are clearly specified. The system is dynamic and allows for the replacement of specifications when and as they cease to be available on the market or change over time, mainly those articles that are transformed in some way because of shifts in fashion, technology, etc. (clothing, furniture, electrical items).

Recommendation: Adopt the international recommendations on definitions for household consumption expenditures in the 1993 SNA, the 1995 European System of Accounts or in the Consumer Price Index Manual, 2004.

\subsection{Scope}

\subsubsection{The scope is broadly consistent with internationally accepted standards, guidelines, or good practices}

The domain of study of the CPI (base year 1991) is the urban area, and the coverage of products corresponds with the concept of household consumption expenditure used in the national accounts. The geographical coverage of the basket and its weights includes residential households in the main towns: La Paz, Santa Cruz, Cochabamba, and El Alto, which accounted for 60 percent of the urban population and 35 percent of the total population in 1990, according to NSI estimates.

The HBS did not investigate collective households (prisons, hospitals, barracks, convents and monasteries, etc.) or the so-called satellite units of the spending unit (domestic servants and pensioners). Moreover, the basket and its weights excluded income quintiles that are higher or lower than the population investigated in the HBS, as it affected the averages. The HBS was applied to a representative sample of individual households and captured information on consumer spending and expenditure not attributable to consumption, both monetary and nonmonetary, in accordance with the conceptual framework in 1968 SNA.

Household consumer expenditure includes all spending in money by the household or of each member on goods for consumption and other costs in respect of services, the costs of repairs to rental homes, on an antichretic or other atypical lease, which do not increase the net worth of the household and are not for the purpose of engaging in productive activity. Goods and services produced by the household and intended for own consumption are not included, nor are wages paid in kind.

In addition to capital expenditures, certain other expenditures are excluded, such as those for dwelling remodeling and expansion, the purchase of real estate, participation in games of chance, donations, theft, losses, transfers to third parties, and the purchase of vehicles.

The CPI basket does not include expenditures not for consumption, such as those for financial services, legal services, contributions, and transfers to third parties. Social transfers from the government to households are also not included, in line with $S N A$ recommendations. 


\subsection{Classification/sectorization}

2.3.1 Classification/sectorization systems used are broadly consistent with internationally accepted standards, guidelines, or good practices

The standard CPI basket (base year 1991) was classified using an adaptation of the Classification of Household Consumption Expenditure by Purpose, in accordance with 1968 $S N A$. The index is calculated for nine chapters: (1) food and drink, (2) clothing and footwear, (3) housing, (4) household equipment and operation, (5) healthcare, (6) transport and communication, (7) education, (8) recreation and culture, and (9) sundry goods and services.

The CHS 2003/2004 classified household consumption in accordance with 1993 SNA, using the Classification of Final Consumption by Purpose adapted to Bolivia. This classification will also be used for the new CPI basket.

\section{$2.4 \quad$ Basis for recording}

\subsubsection{Market prices are used to value flows and stocks}

The prices collected in the CPI are the market prices paid by households in the various retailers and service establishments where they engage in transactions, and include all the taxes levied on the goods and services traded. The prices of merchandise in liquidation are excluded.

\subsubsection{Recording is done on an accrual basis}

To determine the weight structure for the CPI, household final consumption expenditure was measured on a purchase or accrual basis; in other words, it includes goods and services received in the period covered by the HBS, regardless of whether they were paid for or used in that same period or later.

2.4.3 Grossing/netting procedures are broadly consistent with internationally accepted standards, guidelines, or good practices

The CPI basket (base year 1991) does not include automobiles or purchases of durable consumer goods on the secondary market. 


\section{Accuracy and reliability}

\subsection{Source data}

\subsubsection{Source data are obtained from comprehensive data collection programs that take into account country-specific conditions}

The basket of goods and the weight structure for the CPI (base year 1991) was constructed using the results of the HBS carried out by the NSI during a period of 50 weeks between February 1990 and January 1991. The framework for sample selection for the HBS 1990 was constructed from the stratified framework prepared by the NSI in 1980, with mapping updated for the 1988 population and housing census.

Each of the four towns investigated for the HBS constituted an independent area of study, whose framework was stratified by dwelling characteristics. The first stage sample unitprimary sample unit - is a set of 50 or more dwellings situated in one or more districts, and the second-stage or final sample unit is the individual dwelling.

The type of sampling used for the HBS 1990 was two-stage with stratification of the primary sample unit and was self-weighted on a stratum level. The primary sample unit within each stratum was selected by assigning to each unit a selection probability proportional to the number of the individual dwellings of the primary sample unit in the stratum.

The individual dwellings were selected within each primary sample unit by means of a systematic sampling, with a random breakdown. All the households in the selected dwellings were investigated. Investigations were conducted at 6,093 dwellings, spread over four towns (La Paz, 1484 dwellings; Santa Cruz, 1813 dwellings; Cochabamba, 1699 dwellings; and El Alto, 1097 dwellings).

Of the 1,080 goods and services identified in household consumption in 1990, the basket still contained 332 generic products, representing 90 percent of household expenditure. The criterion used for the selection was their relative share in total household spending.

The reporting establishments were selected using data on points of sale with the most supply and competition reported by the HBS in each of the towns (food in markets, neighborhood shops, butcher shops, bakeries, clothes on informal markets, boutiques, specialist shops). The CPI methodology allows for replacement by similar establishments in the same zone in the event an establishment closes, ceases to be representative, or is unwilling to report.

To select the specific articles in the baskets for the four towns, a specifications survey was conducted, targeting various retailers and service establishments, with the aim of identifying the most representative products for each of the generic products. 
In each reporting establishment, the prices of the goods and services are investigated, with a full description of the specifications as to brand name, weight, and unit of measure, so that only one article is found with that description and consequently it has a single price.

Prices are collected directly at various points of sale (La Paz: 2,176, Santa Cruz: 1,601, Cochabamba: 2,013, and El Alto: 1,345), representative of the locations where consumers make their purchases. Approximately 15,540 price valuations are made per month. The data are verified for logical consistency by means of historical comparisons of prices within the same establishment and among establishments of the same type, using computerized tools that generate on-screen reports or printouts. Monthly price fluctuations that fall outside a predetermined interval are compared within the same zone and among various zones.

In cases where there is a monopoly (telephone service, electricity supply, water services, post, issuing of identity cards), there is only one reporter, and the price valuations take place only once a month.

The price of rent is investigated by means of a direct survey of households $(1,393)$, classified by zone, type of dwelling, and type of rent (rent in the strict sense or antichretic leasehold). The sample is divided into four subgroups, rotated every four months.

The frame used for the design of the sample for the CHS 2003/2004 was based on data from the 2001 population and housing census. The primary sample unit (conglomerations of dwellings) and secondary sampling units - census segments of approximately 45 dwellings were selected. The sample size was 9,770 dwellings (towns, other urban centers, and rural areas). For determining the sample size, account was taken of sampling errors of less than 10 percent, calculated on the basis of the household's total income and spending variables, unemployment rate, and the incidence of poverty, in accordance with the Household SurveyMECOVI 2002.

Of the goods and services identified in household consumption in 2003-2004, a preliminary basket of 508 generic products was selected for the new CPI, representing 95 percent of household expenditure, according to the COICOP. The criterion used for the selection was their relative share in the total household spending and the frequency of purchase ( 5 percent or more of households).

\subsubsection{Source data reasonably approximate the definitions, scope, classifications, valuation, and time of recording required}

Prices are investigated daily for the first 28 business days of the month under study, making it possible to estimate the index in accordance with the established periodicity.

The HBS 2003/2004 will be used to update the basket and weights for the compilation of the new CPI, and its methodology, classification, and valuation systems will be based on the 1993 SNA and the COICOP. 


\subsubsection{Source data are timely}

The processes of collecting, reviewing, inputting, validating, and processing data for the CPI and for presenting the results are carried out in accordance with a monthly timetable determined in advance to guarantee that the indicator is disseminated on the first business day of the reference month in Actualidad Estadistica and on the NSI website.

\subsection{Assessment of source data}

3.2.1 Source data-including censuses, sample surveys and administrative records-are routinely assessed, e.g., for coverage, sample error, response error, and nonsampling error; the results of the assessments are monitored and made available to guide statistical processes

The response rate for the HBS 1990 was 90 percent. The processing system for the CPI makes it possible to monitor coverage, by assigning special codes that identify missing prices by product and establishment, as well as the causes thereof (seasonal product, definitive absence, temporary absence). This information is used solely for reaching decisions on replacements for the product or reporting establishment. The percentage of non-responses is very low (3 percent). The design of the prices sample for the CPI (base year 1991) was not based on an analysis of relative errors. The processing programs do not include calculations of relative errors.

The CPI (base year 1991) processing programs generate reports showing historical prices. The price collector evaluates the flagged prices daily, critically assessing and validating them, carrying out a horizontal (historical) and a vertical (present) analysis. Outlying prices and atypical situations are verified through supervision visits. The prices confirmed or modified by this review are recorded on the form with the relevant observations.

The final household consumption expenditure not covered by the CPI basket (base year 1991) is approximately 10 percent. The amount corresponding to products not investigated is distributed among the selected products.

Recommendations: (1) Introduce improvements in the CPI processing system to monitor coverage and the reasons for nonresponse by product/commercial establishment, such as: proportion of prices actually collected, proportion of imputed prices, reasons for imputation, proportion of unexplained atypical data, and proportion of codes substituted because of quality changes; and (2) include in the programs used to process the new CPI the calculation of standard errors in the price relatives from one month to the next, by type of commercial establishment, to generate data that would be helpful for periodically assessing the size of samples, by item and by type of commercial establishment. 


\subsection{Statistical techniques}

\subsubsection{Data compilation employs sound statistical techniques to deal with data sources}

The CPI is subject to a validation process at the level of the primary data from individual price observations, and also at the various aggregation levels of the indices. The indices for the individual products are calculated using a simple arithmetic average of the price relatives series. Instances of nonresponse are minimal, and if they occur, the missing price is attributed to the immediately preceding period. No adjustments are made for differences in quality.

Product varieties that disappear permanently from the market are replaced after two consecutive months for which prices are lacking; this process is carried out by the supervisors. Such products are replaced when a product disappears permanently from most or all the places in which prices are assessed; or when a product is no longer sold in sufficient quantities or under normal conditions. A reporting establishment is replaced when (1) it does not carry the product in a number of observation periods; (2) the data it supplies are not genuine; (3) it ceases to be representative; or (4) it changes management or shuts down definitively. Establishments are replaced by other establishments of a similar size located in the same area.

The forms used for collecting prices have the reporter's code preassigned. The data input module displays a screen which establishes the link between the reporter and the specific products for which the reporter provides information, as well as the immediately preceding price and the corresponding collection code so as to facilitate the identification of special situations, such as temporary absence, permanent absence, seasonal product, changes of specification, sale or promotion price. In addition, the data input module helps add new reporters and assign the associated specific products. This considerably reduces input time as well as coding and input errors.

Recommendations: (1) Introduce into the programs for processing the new CPI a calculation procedure that facilitates imputations for quality changes through the use of implicit methods in their various options, as needed (equivalent quality method, adjustments for changes in quantity, overlapping, linking or chaining), and imputation of the average for the class; and (2) introduce into the new processing system a calculation routine for imputing the prices of any specific missing products. The use of this procedure will depend on the reason for omission (seasonality, temporary shortage, reluctance, difficulty of conducting the interview, total unavailability). Moreover, the geometric mean of short-term price relatives observed in the field should be used.

\subsubsection{Other statistical procedures (e.g., data adjustments and transformations, and statistical analysis) employ sound statistical techniques}

Both the conceptual framework for the HBS 1990 and the basket of goods and services and weights for the CPI (base year 1991) are in keeping with the conceptual and methodological guidelines of the 1968 SNA. The weights include households' purchases in all markets 
(including the informal market) of the goods and services included in consumption expenditure.

The weights in the basket were assessed using the criterion of acquired consumption, in other words the economic cost for the consumer at the time of purchase, regardless of the form of payment (cash or credit). The CPI weights also excluded: (1) the imputed rent of owneroccupied dwellings; (2) financial transactions and investments; and (3) the construction of dwellings.

The recorded value of goods and services represents the economic cost to the consumer at the moment of purchase, whether the payment has or has not been completed and regardless of whether the good or service is used in the same period or subsequently. Goods and services produced by the household for its own consumption are excluded, like primary products (from agriculture, hunting, fishing) and their processing, in-kind withdrawals or self-supply, grants in kind received, and social benefits.

The formula used to calculate the indices at the elementary level (specific products/ establishments) is the short-term price relative, which measures price changes in the current month by comparison with those observed the previous month.

The method used for integrating the elementary indices and arriving at the first level of aggregation (generic product) is the simple arithmetic mean of the linked price relatives for specific products. This formula may introduce biases because the arithmetic mean is affected by extreme values. For the new CPI, the geometric average of the short-term price relatives will be applied.

The calculation at the aggregated subgroup, group, chapter, and general levels is based on the universally accepted Lowe formula, which is an index with fixed weights (quantities consumed in 1990) and reference prices from a subsequent period (1991 average). The weights for the HBS 1990 were not valued at the average prices for 1991.

The formula used to calculate the national index, at all levels of aggregation, is the weighted average of the indices of the four towns investigated. The weight is fixed and is based on each town's share of total national consumption expenditure, according to the HBS 1990.

The index weights have not been updated in the past 16 years. When the new CPI series begins, coefficients will be established to chain it with prior series, and there is a monthly historical series for the national index starting in 1935.

Recommendations: (1) Include imputed rentals of owner-occupied dwellings in the basket for the new CPI, in accordance with the System of National Accounts; (2) use the recommended formula for calculating the indices at the elementary level (specific products/establishment), which is the geometric mean of short-term price relatives; and (3) value the new basket of goods and services at reference period prices for the new CPI. The new basket will have to be updated using the variations recorded by the CPI between the two periods. 


\subsection{Assessment and validation of intermediate data and statistical outputs}

\subsubsection{Intermediate results are validated against other information where applicable}

A posteriori comparisons are made with the corresponding products of the PPI.

\subsubsection{Statistical discrepancies in intermediate data are assessed and investigated}

Atypical variations in the index are assessed, and the specific products and reporting units that have a bearing on the said variations are identified. Both the reference period and the historical trend are analyzed, and comparisons drawn between different establishments. The analysis is supplemented by information from the press, discrepancies are verified, and the reasons for them explained.

\subsubsection{Statistical discrepancies and other potential indicators of problems in statistical outputs are investigated}

An assessment is made of discrepancies in price variations between the various towns investigated for the same products at the subgroup, group, chapter, and general levels.

\subsection{Revision studies}

3.5.1 Studies and analyses of revisions are carried out routinely and used internally to inform statistical processes (see also 4.3.3)

The CPI figures are final when first published. No studies are made to investigate the sources of errors in the data. Nor are the periodic revisions of weights analyzed to determine the effects of the substitution bias on the CPI.

Recommendations: (1) Compare the two baskets (1990 and 2003/2004), assess the changes that have taken place in the structure of consumption, and evaluate their impact at the general level and for classes; and (2) during the testing period for the new CPI, process both indicators simultaneously, weight the changes from one month to the next in the prices of coinciding items, and calculate the aggregate class, group, division, and general changes; analyze the results, and explain any differences. 


\section{Serviceability}

\subsection{Periodicity and timeliness}

\subsubsection{Periodicity follows dissemination standards}

Periodicity follows the recommendations of the General Data Dissemination System (GDDS) and comply with the requirements of the Special Data Dissemination Standard (SDDS).

\subsubsection{Timeliness follows dissemination standards}

CPI compilation begins in the first week of the month and ends on the last business day of the reference month, in accordance with a work timetable that stipulates that the CPI must be published not later than the first day of the following month. The timeliness of the CPI follows GDDS recommendations and is consistent with SDDS requirements.

\subsection{Consistency}

\subsubsection{Statistics are consistent within the dataset}

CPI estimates use various types of classification, such as: (1) type of expenditure; (2) transportable products and nontransportable; and (3) national accounts classification system. Similarly, the national indicator is calculated, in general and for subgroups, groups, and chapters, by aggregating the indices of the various towns. The aggregated indices for each of these classifications and/or integrations are the same.

\subsubsection{Statistics are consistent or reconcilable over a reasonable period of time}

The current CPI series began in March 1992 and to date has been published on a regular monthly basis. In addition, this series of the general index has been chained with other prior series, at the national level since 1935. The formula for chaining with the CPI (base year 1966) is published in the methodological documents.

\subsubsection{Statistics are consistent or reconcilable with those obtained through other data sources and/or statistical frameworks}

The CPI results are reconciled with those reported for the PPI for products appearing in both. 


\subsection{Revision policy and practice}

\subsubsection{Revisions follow a regular and transparent schedule}

CPI figures are not subject to revision following their publication. The household income and expenditure survey, which provides the source data for selection of the basket and weights for the CPI, is conducted at intervals of more than ten years.

\subsubsection{Preliminary and/or revised data are clearly identified}

At the time of disclosure, users are told that the information is final and not subject to modification.

\subsubsection{Studies and analyses of revisions are made public (see also 3.5.1)}

The document entitled Metodología del Cambio de Año Base (Methodology for the Change in Base Year) compares the baskets for 1966 and 1991 and analyzes the major changes occurring at the level of coinciding groups.

Recommendation: Include in the methodological document on the new CPI an analysis of the differences between the two baskets and their weights and the results of the analyses carried out.

\section{Accessibility}

\subsection{Data accessibility}

5.1.1 Statistics are presented in a way that facilitates proper interpretation and meaningful comparisons (layout and clarity of text, tables, and charts)

The CPI is readily accessible to the public and is disseminated either in published form or through direct services to users. The CPI methodology (1991) has been circulated as an NSI publication entitled Sistema de Metadatos - Índice de Precios al Consumidor (Metadata System - Consumer Price Index).

The NSI publishes the monthly CPI in tabular and graphic forms consistent with internationally accepted presentations, facilitating analysis from the domestic perspective and by comparison with other countries. The publications include monthly CPI series and the changes compared with the month prior to the reference month, December of the preceding year, and the same month of the previous year. These indicators are published by town and for the country as a whole, at the various levels of aggregation. Other classifications are also presented, such as transportable goods and nontransportable goods. 


\subsubsection{Dissemination media and format are adequate}

Each month, the publication entitled Actualidad Estadistica includes an analysis of trends for the current period. Detailed estimates are given, and chronological series are included. The results are presented in such a way as to facilitate dissemination in the press and audiovisual media. Recent data and longer time series can be consulted in the NSI electronic database. More comprehensive and/or detailed statistics are disseminated in hardcopy and/or in electronic format.

\subsubsection{Statistics are released on a preannounced schedule}

The statistics are released punctually, that is, in accordance with a preannounced schedule, of which the various media are aware. The preannounced schedule for dissemination is posted on the CBB website.

\subsubsection{Statistics are made available to all users at the same time}

The CPI estimates, both preliminary and definitive, are presented to the Macroeconomic Group, which meets periodically to monitor macroeconomic developments. This practice can, in some cases, produce early access to the information, but it does not interfere with its dissemination to the public.

\subsubsection{Statistics not routinely disseminated are made available upon request}

Apart from statistics that are routinely disseminated, special requests from public or private institutions and private individuals are met. Consultation documents are available in the NSI library. The availability of additional statistics and the procedures to obtain them are publicized on the NSI website.

\subsection{Metadata accessibility}

5.2.1 Documentation on concepts, scope, classifications, basis of recording, data sources, and statistical techniques is available, and differences from internationally accepted standards, guidelines, or good practices are annotated

The metadata for HBS 1990 and the CPI 1991 are published in printed documents and on the NSI website. These documents provide information on the conceptual framework, areas of study, classification systems, data sources, statistical techniques used for the compilation of the CPI, as well as data collection instruments, calculation formula, the basket, and its weights. The methodology and results of CHS 2003/2004 are also available on the NSI website and in the library and the NSI public relations office. 


\subsubsection{Levels of detail are adapted to the needs of the intended audience}

The NSI website contains a section on its economic research and publications, including Sistema de Metadatos Indice de Precios al Consumidor, Encuesta de Presupuestos Familiares 1990 (Household Budget Survey 1990) and Encuesta Continua a los Hogares 2003-2004 (Continuous Household Survey 2003-2004). The methodological documents may be consulted at the NSI library. The reference documents used in formulating the indicator, such as ILO's Consumer Price Index Manual, the 1968 SNA, the 1993 SNA, and the various classification systems (COICOP, ISIC, CPC), may also be consulted at the library.

\subsection{Assistance to users}

\subsubsection{Contact points for each subject field are publicized}

The CPI metadata published on the NSI website identifies the person responsible for the indicator, his/her mailing address, telephone number, and e-mail address, where he/she can be contacted in connection with any question or request regarding the CPI.

Information requests sent in writing or by e-mail are answered within three days, in accordance with NSI rules.

For formal requests that elicit responses requiring signatures of NSI authorities, more time is needed.

\subsubsection{Catalogs of publications, documents, and other services, including information on any charges, are widely available}

Catalogues of publications, documents, and other user services are available at the NSI Customer Service Office and on the NSI website, and are updated periodically. Charges for statistical products and services are publicized, and ordering assistance is provided. 
Table 2. Bolivia: Data Quality Assessment Framework (July 2003): Summary of Results for Price Statistics (Consumer Price Index) (Compiling Agency: National Statistics Institute)

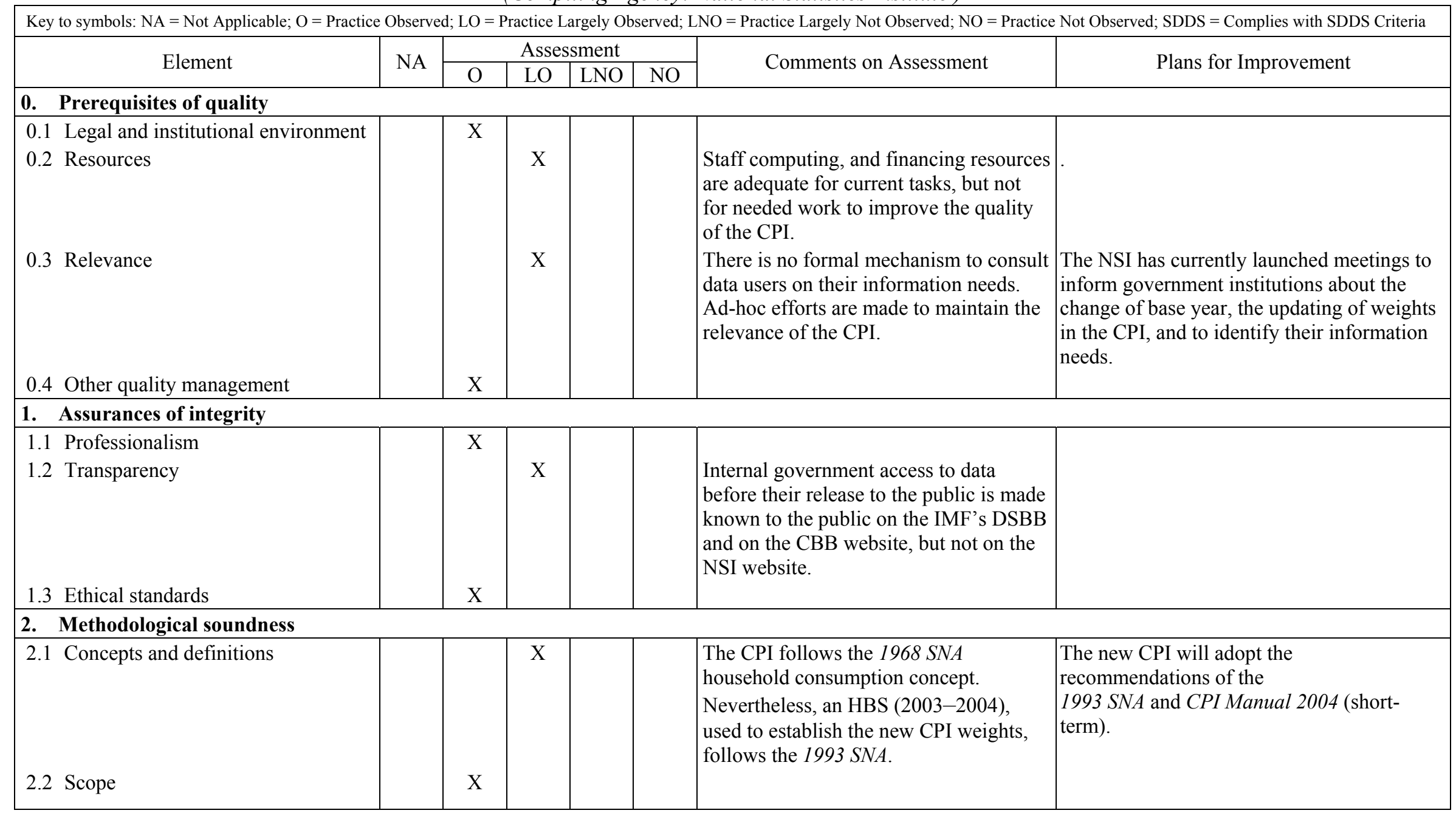


Table 2. Bolivia: Data Quality Assessment Framework (July 2003): Summary of Results for Price Statistics (Consumer Price Index) (Compiling Agency: National Statistics Institute)

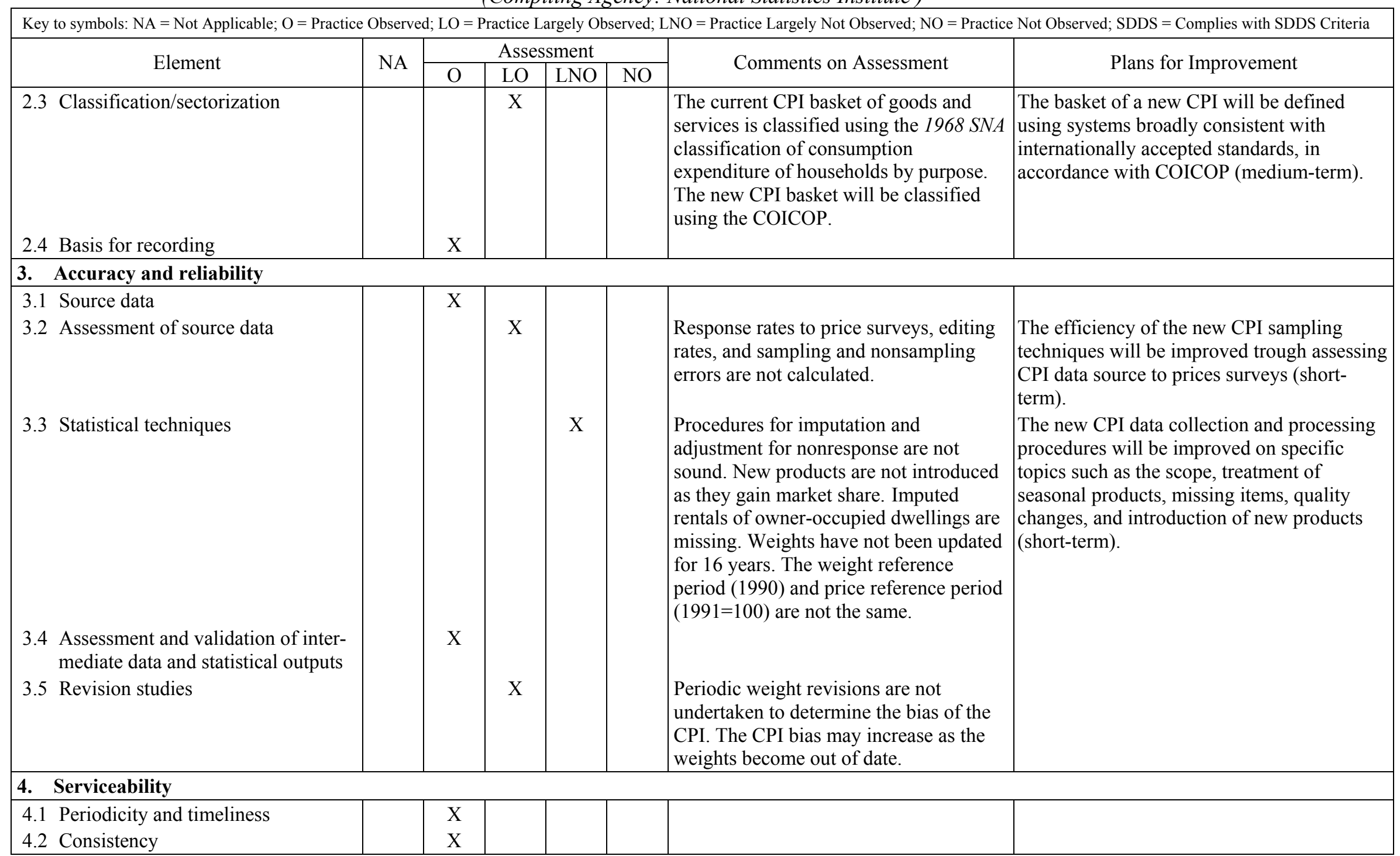


Table 2. Bolivia: Data Quality Assessment Framework (July 2003): Summary of Results for Price Statistics (Consumer Price Index) (Compiling Agency: National Statistics Institute)

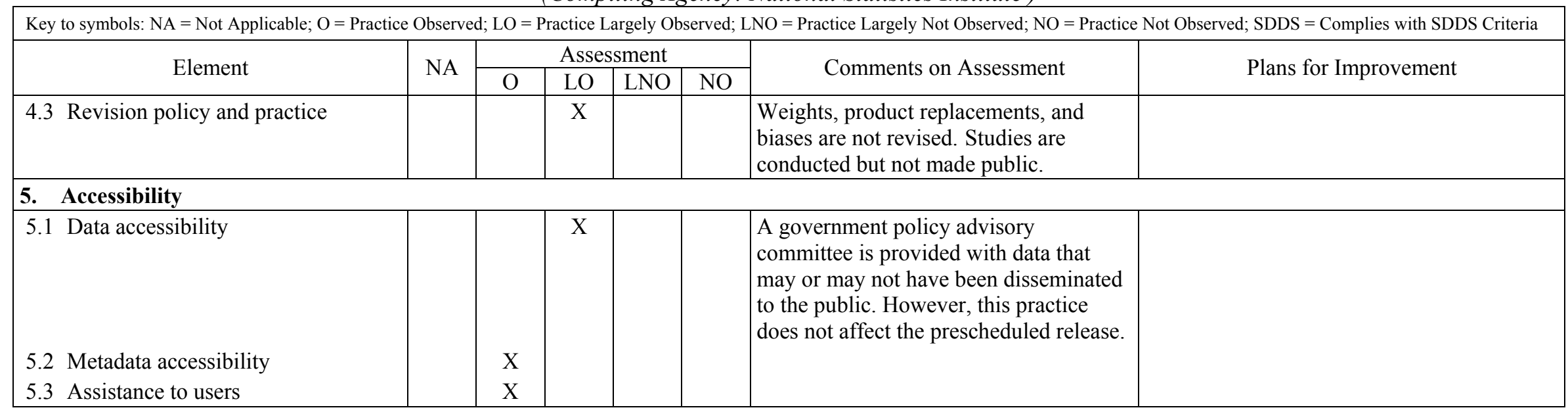




\section{Price Statistics (Producer Price Index)}

\section{Prerequisites of quality}

\section{$0.1 \quad$ Legal and institutional environment}

\subsubsection{The responsibility for collecting, processing, and disseminating the statistics is clearly specified}

The price statistics of Bolivia are compiled and disseminated by the National Statistics Institute (NSI), which has been responsible for compiling the producer price index (PPI) since 1966. DL 14100 of November 5, 1976 created the National Statistical Information System (SNIE).

Within the SNIE, the NSI is a decentralized entity with administrative and operational autonomy. Supreme Decree 24009 established that it was to be accountable to and supervised by the Ministry of Finance (MOF), serve as the executive and technical organ of the SNIE, and be responsible for managing, planning, implementing, monitoring, and coordinating statistical activities. This situation was confirmed by Supreme Decrees 26772, 26973, and 27732.

Chapter III, Article 8(c) of DL 14100 states that the NSI has the following functions: "To compile, prepare, analyze, and publish the statistics indicated in the National Operating Plan and other data necessary for the study of particular aspects of national activities."

Based on the Constitution and on the above-mentioned legal provisions, the NSI drew up the Strategic Institutional Plan 2005-2009, which includes in its matrix of statistical products: (1) the consumer price index (CPI); (2) the producer price index (PPI); (3) the construction cost index; and (4) salaries and remuneration.

\subsubsection{Data sharing and coordination among data-producing agencies are adequate}

Chapter III, Article 8(b) of DL 14100 states that the NSI has the task of coordinating and monitoring the statistical activities of the institutions belonging to the SNIE and ensuring implementation of the National Operating Plan for Statistical Data. Articles 10 and 11 of the same Chapter provide for the establishment of Technical Committees on Statistical Coordination with the participation of the institutions related to the SNIE and established by the NSI, which are required, among other things, to collaborate in drawing up the National Operating Plan for Statistical Data and promote the holding of meetings and conferences on statistics, and the systemization and coordination of national statistical activities through the NSI. In practice, committees of this type are set up to implement interinstitutional studies and agreements but do not function on a permanent basis. 
The Quarterly Manufacturing Survey (QMS) is supplemented with data from administrative records, particularly those of municipal slaughterhouses, to monitor the price of meat and of refined petroleum products, which are researched by the Superintendency of Hydrocarbons.

The NSI is in constant communication with the CBB and the Economic Policy Analysis Unit (UDAPE), and regularly sends these institutions quarterly indices by sector, as well as a record of average prices for approximately 40 generic products. Special requests from these institutions will be accepted in the future.

\subsubsection{Individual reporters' data are to be kept confidential and used for statistical purposes only}

Chapter II, Article 21 of DL 14100 states that data and information obtained by the SNIE are confidential, may be used only for statistical purposes, and may not be revealed in individualized form. Moreover, requests from administrative and judicial bodies for individualized data are not entertained. Article 22 of the same chapter states that "to guarantee statistical secrecy, all institutions belonging to the system and their officials are prohibited from providing or supplying data in violation of the provisions of the previous article." Access to individual data is restricted to the specialists responsible for their compilation.

Data are published in aggregated tables, with no identification of individual reporting units and establishments. Once the information has been transcribed, the related report forms are filed for a period of approximately two years, after which they are moved to NSI central archives.

\subsubsection{Statistical reporting is ensured through legal mandate and/or measures to encourage response}

Title V, Chapter I, Article 15 of DL 14100, which refers to data provision, states that all individuals and legal entities in the country, resident and nonresident, must, within the prescribed period, submit any data and information related by nature and purpose to the activities of the system and required by the NSI.

Article 16 states that all individuals and legal entities must provide the NSI with a copy of their work, studies, charts, plans, sketches, photographs, etc. that may be useful for any study or research undertaken by the system as part of its activities. Violations are punished in accordance with DL 14100 and with such other laws as are duly determined by the Council at the request of the NSI.

The implementation of this decree-law with respect to disclosure is not mandatory, as the person reporting may refuse to participate in a given survey or to disclose some data.

At the beginning of QMS field work, an introductory letter is drafted and sent to each selected reporter to encourage voluntary cooperation, explain the purpose of the study, and 
thank the recipient for responding. In the event of a refusal, the supervisor makes a special visit to the establishment, and the reporter is replaced if the situation does not change.

The price collection form is adapted to each type of establishment so that it includes products researched for the indicator. For each product or raw material, only one variety per establishment is investigated (one that is customarily and widely sold, permanently on the market, and that has readily observable prices). Varieties are described in terms of brand name, unit of measurement, and form of presentation. The price collector delivers the form to the reporter, gives instructions on how to complete the form, and once the information has been provided, consults with the reporter on the causes of price increases or reductions.

\section{$0.2 \quad$ Resources}

\subsubsection{Staff, facilities, computing resources, and financing are commensurate with statistical programs}

The DEIE is part of the Executive Directorate of the NSI and comprises three units:

(1) External Sector Records, Statistics, and Indicators; (2) Price Records, Statistics, and Indicators (UREIP); and (3) Economic Activity Statistics and Indicators (UEIAE). The UREIP is responsible for compiling indicators of producer prices, consumer prices, construction costs, average wages, salaries, and employment. It has a head of unit, six fulltime specialists, and 25 regular employees compiling the PPI.

The UEIAE, which is responsible for collecting prices from producers, serves as the nerve center for QMS field operations. The purpose of the QMS is to capture data used to produce the PPI, prepare volume indicators for production and sales, and conduct surveys of business opinion.

To conduct the QMS, 20 collectors and four regional supervisors are hired quarterly to conduct field work for one month. The recruits have a professional background in economics, administration, and statistics, or are students in these areas. Coordinating the field work is the responsibility of a specialist who is normally a UEIAE staff member.

Processing prices for calculation of the manufacturing PPI is the responsibility of a UREIP specialist, who is supervised by the unit head. The regular employees responsible for coordinating fieldwork and PPI processing have received professional training, particularly in descriptive statistics and sampling, and have attended courses, seminars, and workshops organized by the International and Ibero-American Foundation of Public Administration and Policies and Spain's National Statistics Institute.

The compensation for personnel hired to collect data for the QMS is low, compared with that of collectors hired for other studies. Turnover among field personnel is rather high, with each collector being given an average of three contracts. 
The computer resources used for PPI compilation and processing are insufficient. For each specialist and one of every two field supervisors a computer is assigned. The equipment does not have sufficient capacity. The application used for data entry and indicator calculation, MS Excel, is somewhat limited. The specialist is trained in the use of software packages (Excel, SPSS, Access, Word, and PowerPoint).

Vehicles are not assigned for collecting QMS data. There is a transportation budget for collectors and field supervisors, which covers four bus fares per collector per day.

Budget planning is subject to the NSI's Annual Operating Plan, and the amount allocated for the PPI is the same from one year to the next. The Plan allows salary cost to be covered, as well as overheads for fuel, communications, courier services, and office supplies. There is no budget allocation for the supervision of data collection in the country's hinterland.

Recommendations: (1) Make the necessary improvements for PPI compilation (expand coverage of economic activities and products, produce monthly data, adjust timetable to reflect data disclosure standards, improve data collection processes, standardize quality control for field operations, and develop a new processing system); (2) allocate the necessary resources to the units responsible for the indicator (DEIE and UREIP); and (3) allocate resources for conducting a comprehensive survey.

\subsubsection{Measures to ensure efficient use of resources are implemented}

The performance of PPI staff is evaluated every half year, coordinated by the human resource unit and includes the participation of the Director of the DEIE, the head of the UREIP, and the person responsible for the indicator manager. The following competences are evaluated: analytical capacity, communication, performance under pressure, specific abilities, work organization, interpersonal skills, and quality of service.

The Administrative Services Directorate carries out half-yearly assessments of UREIP progress on the tasks assigned to it for compilation of the PPI, in accordance with the Annual Operating Plan.

Using available resources, the specialists responsible for coordinating the QMS and processing the PPI have instituted procedures for planning and evaluating field operations and generating a price database. A schedule of visits by geographical area is drawn up each quarter, and the workload is distributed between supervisory and collection personnel, based on the number of visits and travel distances. Data collected is completed within one month. Two additional weeks of work are scheduled to generate a price database, and three weeks are added to process, analyze, and publish the indicator. 


\subsection{Relevance}

\subsubsection{The relevance and practical utility of existing statistics in meeting users' needs are monitored}

The PPI is the indicator of price trends in the manufacturing sector, an advance indicator of inflation, and widely used as a deflator in the system of national accounts. The main methodological aspects of the PPI, as well as its results and applications, are available on the NSI website.

No formal mechanism has been established, with the participation of various economic sectors, for discussions on the requirements for producer price information. The NSI responds to user requests (by phone or electronic mail) for information on average prices and explanations of indices and changes. It frequently receives requests from public entities, the press, national bodies, students, and national and foreign analysts. Queries from the communications media are forwarded to a press office and subsequently handled by the UREIP.

Recommendation: Establish a formal mechanism, with the participation of users, to consult them on their information needs, clear up doubts regarding the interpretations, applications, and limits of the PPI, and inform them of any methodological improvements incorporated in the indicator.

\subsection{Other quality management}

\subsubsection{Processes are in place to focus on quality}

In the Strategic Institutional Plan 2005-2009, the NSI defined its mission in the following terms: "To produce and disseminate useful, timely, and reliable official statistics on the national situation," and identified the core principles of service, integrity, quality, confidentiality, and organization. These principles are diffused throughout NSI documents and publications and the orientation programs for persons joining the institution. These principles are also emphasized in the methodological documents and manuals for QMS price collectors and supervisors.

\subsubsection{Processes are in place to monitor the quality of the statistical program}

Procedures have been established for PPI quality control in the various stages of its preparation: planning and supervision of price collection, inputting of prices collected, analysis of prices by establishment for four or more consecutive periods, comparison of prices and changes across establishments, and reviews and analysis of changes from one month to the next by product.

Supervisors organize and distribute work to the price collectors and verify that visits to reporting establishments have been carried out in accordance with the collection schedule 
and standards. Supervisors and price collectors work together to identify errors and inconsistencies in the data gathered, clear up doubts, and correct omissions.

The establishments assigned to each price collector and their visit schedule are monitored, so that fieldwork results can be verified. In addition, a processing system is used to monitor the lack of responses by product and by establishment, as well as the causes for nonresponse (seasonal product, refusal, temporary closure, change in quality).

In 2004, the UREIP received advice from an international expert on improving the quality of data collected and index compilation methods.

Recommendations: (1) Design a processing system that facilitates monitoring of missing prices by product/establishment, and the reasons therof; and (2) keep a record of those reasons, so that the information can be used for continuous PPI quality improvement.

\subsubsection{Processes are in place to deal with quality considerations in planning the statistical program}

The NSI's National Accounts Directorate (NAD) has begun the process of changing the national accounts base year. The plan in this respect is to update the base year and the PPI weights in accordance with 1993 SNA. In addition, PPI coverage will be expanded to include other relevant activities and products, such as crude oil and natural gas, as well as electricity, gas, and water utilities.

\section{Assurances of integrity}

\subsection{Professionalism}

\subsubsection{Statistics are produced on an impartial basis}

The NSI is an autonomous entity responsible for compiling and presenting the PPI. The criteria it applies in carrying out these activities are strictly technical, and compilers are independent in their selection of data sources and processing methods, without interference from other public or private entities. The Director General of the NSI is the person authorized to present the PPI.

Title VII, Chapter II, Article 26 of DL 14100 states that officials assigned to statistical work in all SNIE institutions are statistical personnel and therefore governed by the relevant provisions of the decree-laws on the National System of Administrative Careers and Personnel.

The specialists compiling the various short-term economic indicators have been working in this field for more than ten years. UREIP specialists have followed specialized international courses in price indicators, statistical techniques, sampling, and forecasting models, provided 
by organizations such as Spain's National Statistics Institute and the Economic Commission for Latin America and the Caribbean (ECLAC).

\subsubsection{Choices of sources and statistical techniques as well as decisions about dissemination are informed solely by statistical considerations}

The selection of data sources, as well as the methodologies, concepts, and statistical procedures used in compiling the PPI are in accordance with international standards, which were adopted by the NSI on the basis of strictly statistical considerations. Similarly, results are disseminated solely on the basis of statistical considerations, and the methodological documentation has been prepared and made available to the user public.

\subsubsection{The appropriate statistical entity is entitled to comment on erroneous interpretation and misuse of statistics}

The NSI closely monitors media coverage of its data and, in the event of erroneous interpretations, provides timely public clarifications, using the various means available to it.

\subsection{Transparency}

\subsubsection{The terms and conditions under which statistics are collected, processed, and disseminated are available to the public}

The NSI website contains a section on its economic research and publications, including the major methodological aspects relating to compilation of the PPI for manufacturing (base year 1990).

\subsubsection{Internal governmental access to statistics prior to their release is publicly identified}

The government does not have access to information prior to its release to the public. The methodological document on the PPI (base year 1990) explicitly states that the indicator is published two months after the end of the quarter and identifies the publications in which it will appear. A timetable for presentation of the data is not published. The publication dates are indicated in Calendario Annual de Estadísticas Económicas (Annual Release Calendar of Economic Statistics), published on the CBB website.

\subsubsection{Products of statistical agencies/units are clearly identified as such}

Title V, Chapter I, Article 20 of DL 14100 states that statistical publications must indicate the original sources of the information they contain. Methodological documents, tables and graphs, as well as Actualidades Estadísticas (Statistical Bulletin) and press releases published by the NSI in hardcopy or electronic form, bear the NSI's name and logo. This information is also published on the NSI website. 
The NSI authorizes full or partial reproduction of the information in its publications, provided that the data source is cited.

\subsubsection{Advanced notice is given of major changes in methodology, source data, and statistical techniques}

At the beginning of the current PPI series (base year 1990), the importance and scope of the PPI were publicized through activities such as seminars for journalists and interviews in the audiovisual and print media.

\subsection{Ethical standards}

\subsubsection{Guidelines for staff behavior are in place and are well known to the staff}

The by-laws governing NSI personnel spell out the regulations on the relationships of public servants; state the rights, duties, prohibitions, and incompatibilities pertinent to them; and provide for disciplinary measures to be taken against any public servant violating the rules. In this regard, Article 28(c) of Law 1178 on Government Administration and Control has been incorporated into the by-laws.

NSI personnel are informed of the by-laws during the orientation they receive on joining the institution. In addition, the methodological documents and manuals for price collectors and supervisors in the various surveys emphasize the legal principles requiring personnel to treat all information with discretion and confidentiality.

\section{Methodological soundness}

\subsection{Concepts and definitions}

\subsubsection{The overall structure in terms of concepts and definitions follows internationally accepted standards, guidelines, or good practices}

The concepts and definitions used in the PPI are generally in line with the concepts and definitions of the 1968 SNA and the Producer Price Index Manual, 2004.

The PPI basket (base year 1990) is sufficiently disaggregated and allows for manufacturing price trends to be monitored with respect to 35 branches ( 4 digits), groups ( 3 digits), and divisions (2 digits), in accordance with the International Standard Classification, Revision 2 (ISIC Rev. 2). Other special classifications are also prepared in areas such agroindustry and other manufacturing industries, as are indices classified by economic use.

The products investigated at each establishment are accurately and thoroughly described in terms of quality, unit of measurement, and forms of presentation and transaction. The system is dynamic and allows for specifications to be replaced when and as they change over time, 
particularly those products that are transformed in some way due to shifts in fashion, technology, etc.

The prices measured are those received by the producer at the factory gate and do not include distribution markups or product taxes (VAT or other similar deductible tax billed to the purchaser). Nevertheless, it is worth noting that for some such groups, the selling price of their products are not monitored; rather, price changes for their main products are imputed, for example: printing offices, editorial and related industries, plastic products, glass and glass manufactured products, structural metallic products, jewelry, and similar articles.

Recommendations: (1) Adopt the international recommendations in the 1993 SNA and in the Producer Price Index Manual, 2004, particularly to determine the weights, which should be linked to the market output of finished goods; market output should be valued at significant prices and include changes in inventory and production for own final use; and (2) estimate indices by type of economic activity (4 digits, ISIC Rev. 3) and for the main products, depending on the extent to which the country has adapted the CPC.

\subsection{Scope}

2.2.1 The scope is broadly consistent with internationally accepted standards, guidelines, or good practices

Bolivia's PPI relates to manufacturing. It does not cover other economic activities such as agriculture, forestry, mining, energy, water, construction, commercial services, and other services.

Producer price indices measure changes in selling prices on the domestic market, and their coverage is limited to goods produced by 35 branches (four digits, 125 generic products (six digits), and 218 specific manufacturing products. In the selection of products, an effort was made to cover at least 70 percent of the gross output value of each branch, as done in the 1990 industrial survey.

The sample of establishments investigated for PPI prices includes manufacturing companies located in all departments (except Pando), and accounted for at least 75 percent of the output value of the product investigated. Small enterprises (incorporated or not) are not included, nor are illegal markets.

The methodological notes for the PPI (base year 1990) are explicit as regards the coverage of the weights for the indicator and the prices investigated. The limitations of their scope compared with the scope recommended in the 1968 SNA or the 1993 SNA are not mentioned.

Recommendation: Expand the coverage of the PPI so that it represents a larger proportion of the total production of resident establishments and companies, initially including, in addition to manufacturing, other relevant activities and products, such as crude oil and natural gas, as well as electricity, gas, and water utilities.

Price Statistics (Producer Price Index) 


\subsection{Classification/sectorization}

2.3.1 Classification/sectorization systems used are broadly consistent with internationally accepted standards, guidelines, or good practices

Establishments are classified by main economic activity in accordance with ISIC Rev. 2 . A country-specific code derived from a breakdown to six digits of ISIC Rev. 2 is used for generic products. Price indices are calculated for the primary economic activity of establishments and companies, but not for groups of products.

Recommendation: Adopt the 1993 SNA guidelines, specifically ISIC Rev. 3, to classify the main economic activity of companies and establishments, and the CPC or a compatible national classification to classify products.

\subsection{Basis for recording}

\subsubsection{Market prices are used to value flows and stocks}

The value of output, a weighting variable used for integrating the price relatives of generic products and estimating group indices, is expressed in producer prices. The prices collected are producers' factory-gate selling prices, excluding value-added tax and any other similar deductible tax, as well as distribution margins. This price concept is consistent with international practices for the valuation of output.

\subsubsection{Recording is done on an accrual basis}

The weighting variable (value added) is derived from the system of national accounts, where transactions are recorded at market prices and on an accrual basis.

\subsubsection{Grossing/netting procedures are broadly consistent with internationally accepted standards, guidelines, or good practices}

As indicated above, the prices investigated for the PPI are producers' factory-gate selling prices, and transactions between establishments within the same enterprise are recorded on a gross basis.

\section{Accuracy and reliability}

\subsection{Source data}

3.1.1 Source data are obtained from comprehensive data collection programs that take into account country-specific conditions

The PPI for manufacturing is based on a quarterly survey of a sample comprising 313 establishments, selected from a group of 1,300 companies investigated in the 
1990 industrial survey. This survey was carried out in accordance with international standards and supplemented with data from administrative records, as well as with estimates of national accounts for 1990. Beginning in 2002, a statistical gap appears in the annual surveys of companies and establishments, which complicates the addition of new establishments and products.

The PPI for manufacturing comprises 35 branches (four digits), 125 generic products (six digits), and 218 specific products. According to the estimates from the system of national accounts, the branches researched accounted for 85 percent of the manufacturing value added for 1990.

Prices are compiled quarterly, based on data provided by 313 establishments, which report the monthly prices for 633 specific products. The sample of establishments surveyed is stratified and targeted. A stratum for mandatory inclusion was selected, comprising establishments with over 15 employees, and was supplemented by a random stratum consisting of establishments with 5-14 employees.

The sample framework used as a basis for selecting the sample of establishments for the PPI is not updated, which limits the application of suitable methods for selecting samples. In this regard, the NSI began to prepare a directory containing data from Inland Revenue and Fundaempresa, a business development foundation with a current membership of 14,000 businesses.

Recommendations: (1) Continue updating the directory of businesses and establishments, which will serve as the framework for sampling designs; (2) expand PPI coverage in terms of the branches studied, to guarantee coverage representing over 80 percent of value added; within each branch selected, the survey should focus on products that account for at least 80 percent of output value (supply and use tables); the PPI basket should be broken down so that the index can be estimated at the three-and four-digit levels; (3) stratify the framework of businesses and establishments and use scientific techniques of random sampling to select businesses and establishments in the small and medium-sized strata; and (4) periodically evaluate the sample size by branch and by product.

\subsubsection{Source data reasonably approximate the definitions, scope, classifications, valuation,} and time of recording required

As mentioned above, the source data used to select the basket of products and establish the PPI weights for manufacturing are taken from the annual Industrial Survey conducted by the NSI in 1990. This survey was conducted in accordance with international recommendations and was supplemented by data from the national accounts estimates, which follow the guidelines of $1968 S N A$.

The prices researched for the PPI are producers' factory-gate selling prices, and transactions between establishments of the same enterprise are not recorded. 


\subsubsection{Source data are timely}

The processes of collecting, reviewing, inputting, validating, and processing data for the PPI and for presenting the results are carried out in accordance with the following quarterly timetable: (1) price investigations begin in the second week of the month following the reference quarter and prices are collected on the $15^{\text {th }}$ or nearest business day of each month in the quarter; (2) the data are recorded, and processing is completed in the six weeks following the reference quarter; and (3) the PPI is published two months after the end of the quarter and is distributed to internal and external users.

Recommendation: Adjust the processes for collecting and processing the PPI so that the index can be estimated monthly and with the timeliness required for disseminating this type of indicator (1-2 months after the end of the reference month).

\subsection{Assessment of source data}

3.2.1 Source data-including censuses, sample surveys and administrative records-are routinely assessed, e.g., for coverage, sample error, response error, and nonsampling error; the results of the assessments are monitored and made available to guide statistical processes

The PPI response rate is approximately 95 percent for establishments and 90 percent for specific products. The lack of responses by product and establishment, as well as the causes thereof (seasonal product, definitive absence, temporary absence, change in quality), can be monitored by using an indicator spreadsheet. This information is used solely for reaching decisions to replace products or establishments for calculation purposes, but not for changing the design.

The validation process involves two types of consistency analysis: (1) horizontal consistency, by analyzing the establishment's data over a period of time to detect and verify atypical changes; and (2) vertical consistency, by comparing changes reported by the various establishments in the sample.

The PPI processing program generates reports showing outlying prices and variations. The analyst evaluates the prices and critically assesses and validates them. Outlying prices and atypical situations are verified through supervision reviews. The prices confirmed or modified by this review are recorded on the form, along with the relevant observations.

Data from external sources is regularly assessed and analyzed, as are adjustments in the prices of refined petroleum products, which are validated using the data provided by the Superintendency of Hydrocarbons.

The activities comprising the PPI basket account for a low percentage of GDP (13.9 percent). 
Recommendation: Introduce improvements in the PPI processing system to monitor coverage and the reasons for nonresponse by product/commercial establishment, such as: proportion of prices actually collected, proportion of imputed prices, reasons for imputation, proportion of unexplained atypical data, and proportion of codes substituted because of quality changes.

\subsection{Statistical techniques}

\subsubsection{Data compilation employs sound statistical techniques to deal with data sources}

The price collection forms have a preassigned reporter's code. Coding is performed by the supervisor and verified by the specialist. In addition, the data input module facilitates the addition of new establishments, the assignment of related products, and the creation of printed forms from the database. This considerably reduces input time, as well as coding and input errors.

The PPI is subject to a validation process at the primary data level. This process is carried out by the collector directly in the establishment, using a price list to verify any increases or decreases of more than 20 percent and to discuss the causes of such changes with the reporter. The form includes a section in which reporters can explain these causes and also describe changes in brand, unit of measurement, or origin.

The percentage of missing prices is about 10 percent (temporary or definitive absence, nonresponse, seasonality). In these cases, the missing price is imputed, and the price change for similar specific products is applied. This imputation is performed using analysis, and no automated program is used for this purpose. When similar products show minor changes, the price for the previous month is repeated.

Specific products that permanently disappear from the establishment are replaced in the same establishment by a specific product with similar characteristics. Specific products that disappear permanently from the market are replaced, after two consecutive months of missing prices, by the specialist responsible for validating, analyzing, and calculating the indicator.

Recommendations: (1) Include in the new processing system a calculation procedure for imputing specific product prices where they are missing; use of this procedure will depend on the reason for omission (seasonality, temporary shortage, reluctance, difficulty of conducting the interview, total unavailability); and (2) impute the geometric mean of shortterm price relatives for similar products (same establishment, same generic product, same type of activity).

\subsubsection{Other statistical procedures (e.g., data adjustments and transformations, and} statistical analysis) employ sound statistical techniques

The basket weights for PPI products are based on the gross value of output at producer prices and are taken from the annual Industrial Survey conducted by the NSI in 1990. The weights 
for the branches (ISIC Rev. 2, four digits) are based on the value added estimated by the system of national accounts for 1990. These estimates were calculated in accordance with international recommendations and are compliant with the guidelines of 1968 SNA.

The formula used to calculate the indices at the elementary level (specific products/establishment) is the short-term price relative, which measures price changes in the current month by comparison with those observed the previous month.

The method used for integrating the elementary indices and arriving at the first level of aggregation (generic product) is the simple arithmetic mean of the linked price relatives for specific products. This formula can introduce biases because the arithmetic mean is affected by extreme values.

The calculation at the aggregated branch, group, division, and general levels is based on the universally accepted Laspeyres formula.

The base year for PPI prices is 1990. The weights are valued at the prices for the index reference period and have not been updated in 16 years, which has led to a substantial loss in the representativeness of the basket of products researched.

There are PPI series combined with the earlier series of the index (PPI base year 1985) at the general level by branch (four digits).

Recommendations: (1) Update the PPI basket and weights as part of the program to change the base year for the national accounts; (2) use the geometric mean for short-term price relatives for calculating indices at the elementary level (specific products/establishment); and (3) combine the PPI series (base year 1990) with the new PPI, in accordance with the recommendations of the Producer Price Index Manual, 2004.

\subsection{Assessment and validation of intermediate data and statistical outputs}

\subsubsection{Intermediate results are validated against other information where applicable}

The intermediate results for the PPI are validated against those reported for the CPI, while export price indices are validated against products appearing in both indices. Trends in "relative prices" are analyzed by comparing changes at the aggregate level for different types of activities.

\subsubsection{Statistical discrepancies in intermediate data are assessed and investigated}

The specialist responsible for analyzing the PPI validates the raw data, reviews and compares them for two successive periods ( $t$ and $t-1)$, evaluates outlying prices, checks the explanations of price changes provided by the reporter, makes the necessary adjustments, and checks the impact of the adjustment. 
The reference period and historical trends are analyzed, and the various establishments compared. The analysis is supplemented by information from other price data sources and from the press. Discrepancies are analyzed, and the reasons for them explained.

\subsubsection{Statistical discrepancies and other potential indicators of problems in statistical outputs are investigated}

Discrepancies in the price variations between the various levels of disaggregation (branches, groupings, and divisions) and the PPI classification (economic use: nondurable consumer goods, intermediate goods, capital and durable consumer goods; agro-industry and other manufacturing industries) are analyzed.

\subsection{Revision studies}

3.5.1 Studies and analyses of revisions are carried out routinely and used internally to inform statistical processes (see also 4.3.3)

Should recurrent price fluctuations occur, the possible sources of collection errors are investigated, and the necessary adjustments made. The indicator is then recalculated. For this reason, the PPI is considered to be preliminary for two or three consecutive periods. No periodic reviews are carried out to assess how changes in the weighting structure may affect the PPI.

Recommendations: (1) Assess the impact of imputing missing prices on PPI estimates at the aggregate level; (2) document PPI revisions, indicating the reason for them and their impact on the index at the various aggregation levels.; (3) assess the changes noted in the weighting structure of the manufacturing industry PPI for the various aggregation levels; and (4) during the testing period for the new PPI, process both indicators simultaneously, weight the changes in prices of overlapping products from one month to the next, and calculate the aggregate change for each basket; compare results, determine the impact of the changes at the various levels of aggregation, analyze the results, and explain the differences.

\section{Serviceability}

\subsection{Periodicity and timeliness}

\subsubsection{Periodicity follows dissemination standards}

Given that prices for the PPI are collected and compiled quarterly, there is no consistency with the Special Data Dissemination Standard (SDDS) and no compliance with the recommendations of the General Data Dissemination System (GDDS).

Recommendation: Compile the PPI on a monthly basis, in compliance with the SDDS and the GDDS. 


\subsubsection{Timeliness follows dissemination standards}

PPI compilation begins in the second week after the end of the reference quarter. The PPI is published ten weeks after the end of the reference quarter; the requirements of the SDDS and the GDDS are therefore not observed.

Recommendation: Disseminate the monthly PPI no later than one month after the close of the reference month (SDDS) or no later than two months after the close of the reference month $(G D D S)$.

\subsection{Consistency}

\subsubsection{Statistics are consistent within the dataset}

PPI estimates are performed for various types of classifications, such as: (1) economic activity; (2) economic use (consumer goods, capital goods, and intermediate consumer goods); and (3) sector (agro-industry and other manufacturing industries). The aggregated indices for each of these classifications are the same.

\subsubsection{Statistics are consistent or reconcilable over a reasonable period of time}

The current PPI series began in January 1991 and has been published regularly every quarter since then. In addition, this new series of the index was chained with the previous series, which had a base year of 1985, both at the general level and for overlapping activities. The chained series are published in the NSI Statistical Yearbook 2003.

\subsubsection{Statistics are consistent or reconcilable with those obtained through other data sources and/or statistical frameworks}

The PPI results are reconciled with those reported for the CPI for products appearing in both indices.

\subsection{Revision policy and practice}

\subsubsection{Revisions follow a regular and transparent schedule}

There is no program for the regular updating of the PPI. The study used as the basis for selection of the basket and calculation of PPI weights is conducted at intervals exceeding ten years. There is no regular revision schedule. The figures remain preliminary for a period exceeding that indicated in the PPI metadata (two to three periods). 
Recommendations: (1) Standardize the PPI revision cycle in accordance with best practices: the indices should be preliminary only for one period, so that when data for the next period are published, the data published in the preceding period are confirmed or revised; and (2) in cases where numbers are revised to correct identified errors, inform the public about it.

\subsubsection{Preliminary and/or revised data are clearly identified}

The letter (p) is used to denote preliminary data appearing in the PPI tables. When the data are revised, the letter is removed, but it is not explicitly stated that the data have been revised. Significant revisions are explained in a footnote to the table.

Recommendation: The publications should identify the data that have been revised.

\subsubsection{Studies and analyses of revisions are made public (see also 3.5.1)}

No periodic reviews are carried out to assess the possible effects of changes in the weighting structure on the PPI. Should an adjustment be made to compensate for collection errors, or should missing prices be incorporated into the PPI, the pertinent explanations are provided and the corrected data are clearly identified.

Recommendations: (1) Use a footnote to indicate the coverage of both the preliminary data and the revised data; (2) perform a comparative analysis of any discrepancies between the original and the final data, and record a series of such discrepancies to assess the reliability of the preliminary data, based on their coverage; and (3) document these analyses.

\section{Accessibility}

\subsection{Data accessibility}

5.1.1 Statistics are presented in a way that facilitates proper interpretation and meaningful comparisons (layout and clarity of text, tables, and charts)

The quarterly PPI is published in a table format to facilitate analysis. These tables include: quarterly series by branch; economic use (consumer goods, capital goods, and intermediate consumer goods); and sector (agroindustrial and other manufacturing industries); and the changes in the series from the quarter preceding the reference quarter, cumulative changes, and changes compared with the previous year.

\subsubsection{Dissemination media and format are adequate}

The results at the general level and by branch are published in the NSI yearbook, available in print and on CD-ROM. Other, more disaggregated outputs are produced in response to user requests. The yearbook is available on the NSI website and in pdf format. 


\subsubsection{Statistics are released on a preannounced schedule}

An annual release calendar of economic statistics is posted on the CBB website, showing the publication dates for the quarterly PPI (May, August, November, and February). The Press Office is responsible for sending the tables to external users. Data are also available to users at the NSI library. Special requests for statistics or supplementary explanations are handled by e-mail, in writing, or by telephone.

\subsubsection{Statistics are made available to all users at the same time}

No government officials outside the NSI have access to the information prior to its release to the general public.

\subsubsection{Statistics not routinely disseminated are made available upon request}

Apart from statistics that are routinely disseminated, special requests from public or private institutions or from individuals are also met. Reference documents are available at the NSI library. The availability of additional statistics and the procedures to obtain them are publicized on the NSI website.

\subsection{Metadata accessibility}

5.2.1 Documentation on concepts, scope, classifications, basis of recording, data sources, and statistical techniques is available, and differences from internationally accepted standards, guidelines, or good practices are annotated

PPI metadata (base year 1990) for the manufacturing industry are published in print and on the NSI website. These documents contain the conceptual framework, areas of study, classification systems, data sources, statistical techniques used to compile the PPI, data collection instruments, as well as the calculation formula, basket, and weights used.

\subsubsection{Levels of detail are adapted to the needs of the intended audience}

The NSI website contains a section on economic studies and publications, such as the Annual Survey of the Manufacturing Industry and the Metadata System for the Industrial Manufacturing Producer Price Index. Similarly, users may consult at the library, the reference documents used to formulate the indicator, such as the ILO's Consumer Price Index Manual, the $1968 S N A$, the 1993 SNA, and the various classification systems (COICOP, ISIC, CPC). 


\subsection{Assistance to users}

\subsubsection{Contact points for each subject field are publicized}

The PPI Metadata System published on the NSI website identifies the person responsible for the indicator, as well as his or her mailing address, telephone number, and e-mail address at the NSI. Users may contact this person for any PPI-related enquiries or requests.

Requests for information submitted in writing or by e-mail are processed within three days, following NSI procedure. For formal requests that elicit responses requiring the signature of NSI officials, more processing time is needed.

\subsubsection{Catalogs of publications, documents, and other services, including information on any charges, are widely available}

Catalogues of publications, documents, and other user services are available at the NSI

Customer Service Office and on the NSI website, and are updated periodically. Charges for statistical products and services are publicized, and ordering assistance is provided. 
Table 3. Bolivia: Data Quality Assessment Framework (July 2003): Summary of Results for Price Statistics (Producer Price Index)

(Compiling Agency: National Statistics Institute)

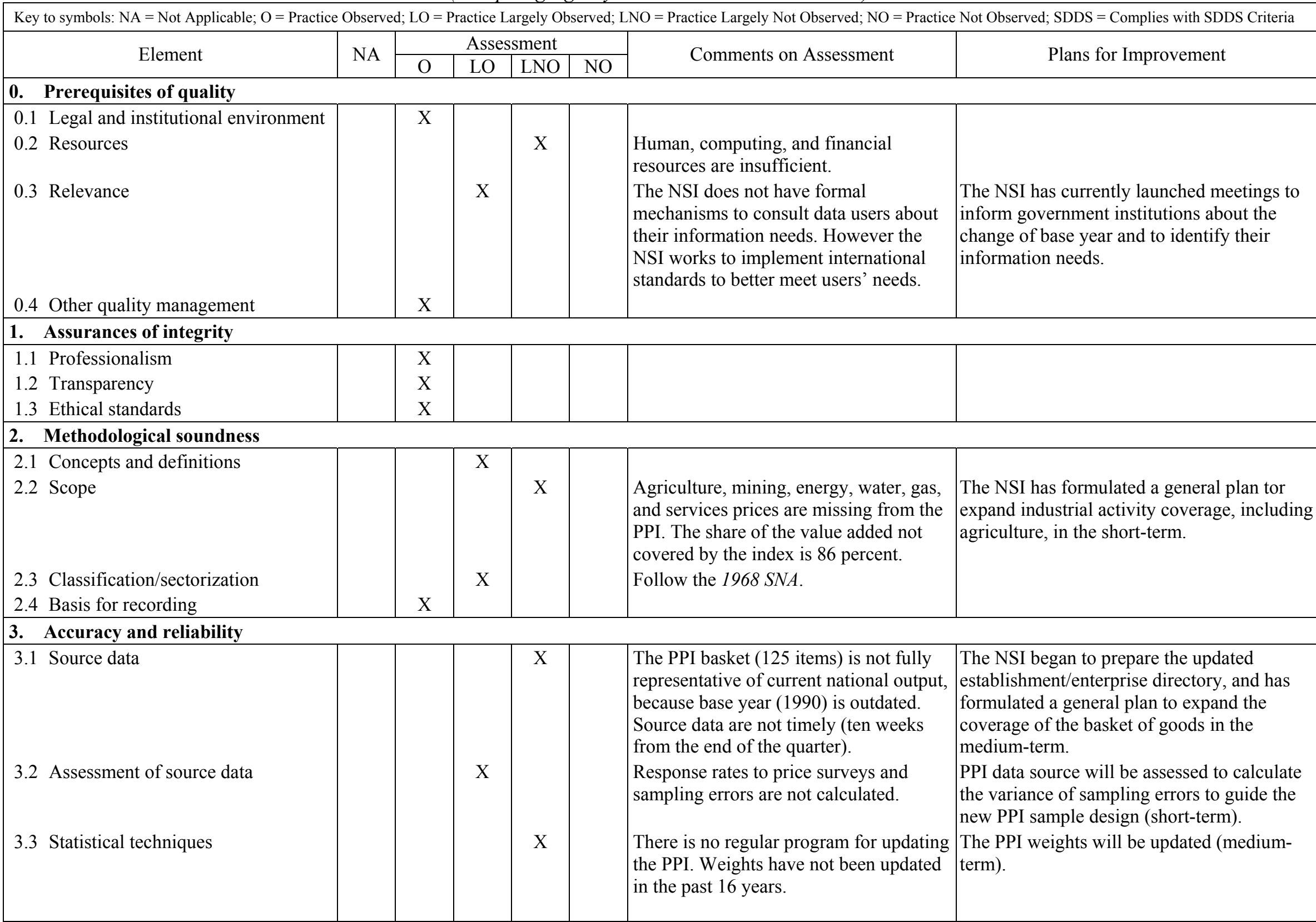


Table 3. Bolivia: Data Quality Assessment Framework (July 2003): Summary of Results for Price Statistics (Producer Price Index)

(Compiling Agency: National Statistics Institute)

\begin{tabular}{|c|c|c|c|c|c|c|c|}
\hline \multirow{2}{*}{ Element } & \multirow{2}{*}{ NA } & \multicolumn{4}{|c|}{ Assessment } & \multirow{2}{*}{ Comments on Assessment } & \multirow{2}{*}{ Plans for Improvement } \\
\hline & & $\mathrm{O}$ & LO & LNO & $\mathrm{NO}$ & & \\
\hline $\begin{array}{l}\text { 3.4 Assessment and validation of inter- } \\
\text { mediate data and statistical outputs } \\
\text { 3.5 Revision studies }\end{array}$ & & $\mathrm{X}$ & $\mathrm{X}$ & & & $\begin{array}{l}\text { Periodic weight revisions are not } \\
\text { undertaken to determine the bias of the } \\
\text { PPI. The PPI bias may increase as the } \\
\text { weights become out of date. Analyses of } \\
\text { revisions are carried out, but not revision } \\
\text { studies. }\end{array}$ & \\
\hline \multicolumn{8}{|l|}{ 4. Serviceability } \\
\hline 4.1 Periodicity and timeliness & & & & $\mathrm{X}$ & & $\begin{array}{l}\text { Periodicity and timeliness does not meet } \\
\text { GDDS recommendations. The PPI is } \\
\text { compiled quarterly and published with a } \\
\text { lag of ten weeks. }\end{array}$ & $\begin{array}{l}\text { The periodicity and timeless of the PPI will } \\
\text { be improved (medium-term). }\end{array}$ \\
\hline 4.2 Consistency & & $\mathrm{X}$ & & & & & \\
\hline 4.3 Revision policy and practice & & & $\mathrm{X}$ & & & $\begin{array}{l}\text { Revisions do not follow a regular } \\
\text { schedule. Preliminary data are clearly } \\
\text { identified, not so revised data. } \\
\text { Analyses and studies of revisions are not } \\
\text { disseminated. }\end{array}$ & \\
\hline \multicolumn{8}{|l|}{ 5. Accessibility } \\
\hline 5.1 Data accessibility & & & $\mathrm{X}$ & & & $\begin{array}{l}\text { Data only published in the annual } \\
\text { yearbook. Quarterly dissemination has } \\
\text { been suspended. An advance release } \\
\text { calendar is available on the IMF's } \\
\text { DSBB and the CBB website, but not on } \\
\text { the NSI website. }\end{array}$ & $\begin{array}{l}\text { The NSI will disseminate the advance release } \\
\text { calendars on its website (short-term). }\end{array}$ \\
\hline 5.2 Metadata accessibility & & $\mathrm{X}$ & & & & & \\
\hline 5.3 Assistance to users & & $\mathrm{X}$ & & & & & \\
\hline
\end{tabular}




\section{GOVERnMENT FinANCE Statistics}

\section{Prerequisites of quality}

\subsection{Legal and institutional environment}

0.1.1 The responsibility for collecting, processing, and disseminating the statistics is clearly specified

Government finance statistics (GFS) ${ }^{4}$ are collected, compiled, and disseminated by the Ministry of Finance (MOF). The MOF's data collection, compilation, and dissemination responsibilities are in accordance with the terms and conditions stated by: (1) the Law on the Organization of the Executive Branch (Law No. 3351 of February 21, 2006) and its regulation decree (Decree No. 28631 of March 09, 2006); (2) the Law of Government Administration and Control (Law No. 1178 of July 20, 1990); (3) the Decree that creates and establishes functions of the Fiscal Programming Unit (UPF) in the MOF (Decree No. 27372 of February 17, 2004); (4) the Law of Budgetary Administration (Law No. 2042 of December 1, 2005); (5) the Basic Norms of Budgetary System (Resolution No. 225558 of March 04, 2005); (6) the Basic Norms of Integrated Accounting (Resolution No. 222957 of March 04, 2005); (7) the Basic Norms of Public Credit; (8) the Law of Municipalities (Law No. 2028 of October 28, 1999); (9) the Decree on the Creation of the Integrated System of Management and Administrative Modernization (SIGMA) (Decree No. 25875 of August 18,2000 ) and the Decree on the Use of the SIGMA (Decree No. 26455 of December 19, 2001); (10) the Organic Law of the Central Bank of Bolivia (CBB) (Law No. 1670 of October 31, 1995) and its Regulation for the Recording of Public and Private Debt (Directory Resolution No. 113/2003); (11) the Decree-Law of the National System of Statistical Information (SNIE) (Decree-Law No. 14100 of October, 1976); (12) the Law on Transparency and Access to Government Information (Decree No. 27329 of January 31, 2004); and (13) the Constitution of April 13, 2004. These laws and formal provisions provide adequate support for the compilation of fiscal data by the MOF. However, the responsibility for GFS collection, compilation, and dissemination is shared by two units in the MOF, the UPF as it is indicated by Articles 3 and 4 of Decree No. 27372 and an internal provision in the manual of functions for the MOF units, and the General Directorate of Accounting (GDA) as it is indicated by Article 43 of the Resolution No. 222957.

Recommendation: Improve coordination between the two units of the MOF that share the responsibility of GFS compilation, to achieve comprehensive collection, compilation, and dissemination of GFS.

\footnotetext{
${ }^{4} \mathrm{GFS}$ refers to fiscal data compiled and disseminated, for analytical purposes, according to internationally accepted standards, such as A Manual on Government Finance Statistics 1986 (GFSM 1986) and the Government Finance Statistics Manual 2001 (GFSM 2001). Fiscal data refers to GFS, budgetary, and accounting data.
} 
The Law on the Organization of the Executive Branch establishes the number of ministries, their functions, and other provisions related to the organization of the Executive Branch. Article 4 states, among others, the functions of the MOF. These functions include: designing, executing, and monitoring fiscal policy with regards to treasury, public debt, integrated accounting, budget preparation and execution, and tax and custom policy issues. Its regulation decree states in Article 29 the types and characteristics of public institutions (deconcentrated, decentralized, and autarkic public institutions), public enterprises, and public-private corporations under the Executive Branch's control. Article 58 states the MOF organizational structure, and Article 60, the functions of each vice-ministry. Thus, the Vice Ministry of Budget and Accounting has, among others, the responsibility to design and produce specific provisions, manuals, and procedures for the budget process. This Vice Ministry also is in charge of the preparation of the budgetary classifications and the central administration financial statements, and the administration of the SIGMA. The Vice Ministry of Treasury and Public Credit has, among others, the responsibility of preparing and following up the fiscal and financial programming through the consolidation of the public sector cash flows. This function is performed in coordination with the CBB and other relevant institutions. Also, this regulation decree includes the list of public institutions, with a breakdown by deconcentrated, decentralized and autarkic public institutions, under the control of each ministry.

The Law of Government Administration and Control regulates the administration and control systems of the public resources. These systems include, among others, the budgetary, treasury and public credit, and integrated accounting subsystems, which are applied to all public sector entities. The budgetary subsystem provides amounts and sources of financial resources for every fiscal year; the treasury and public debt subsystem manages revenues and financing, and arranges commitments, liabilities, and payments for the budget execution; and the integrated accounting subsystem incorporates the budgetary, financial, and net worth transactions in a unique system to compile relevant information for policy decision making.

The Decree No.27372 states that, within the Vice Ministry of Treasury and Public Credit of the MOF, the preparation and follow-up of fiscal programming has been assigned to the UPF. This unit provides reliable and timeliness information for fiscal policy decision making through the collection and compilation of economic and financial information. This activity is closely coordinated with the CBB. Among its functions, the UPF has to (1) collect and compile economic and financial information of the public sector entities; (2) prepare the fiscal programming through the preparation, consolidation, and forecasting of the public sector financial information; (3) guarantee the consistency of the fiscal programming with the general budget, and relevant balance of payment, national accounts, and financial system aggregates; (4) determine, monthly, the deficit/surplus of the public sector; (5) publish, periodically, fiscal information; (6) participate in discussions and negotiations with international organizations regarding the fiscal programming; and (7) analyze trends of revenues, expenses, and financing of public sector. Additionally, the UPF compiles and disseminates monthly GFS, including data to meet the General Data Dissemination Standards 
(GDDS) recommendations, and prepares fiscal analysis reports that include tables and graphics. The UPF disseminates this information on the MOF website.

The Law No. 2042 provides the general norms for the budgetary process of each fiscal year ${ }^{5}$ that should be applied to all public sector entities and all units that receive transfers from the Treasury. The Resolution No. 225558 states that the budgetary classifications should be prepared and approved by the MOF every fiscal year. A single set of budget classifications is used for compilation, approval, and execution of the public sector budget. The budget includes: (1) institutional classification, (2) resource classification by items, (3) expense classification by object, (4) classification of expense by function and purpose, (5) classification by sources of financing, and (6) others.

Article 2 of Resolution No. 222957 states that the basic norms and principles of the Integrated Accounting System are of application to all public sector entities; Article 3, the institutional structure of public sector; Article 9, the concepts and definitions of the integrated accounting system and that it includes budgetary, economic, financial, and net worth records; Article 13, that the SIGMA is the management system of all the recording indicated in Article 9; Article 21, the basis of recording of resources (estimation, accrual, and received) and expenses (appropriation, commitment, accrual, and paid); Article 28, the structure of the Chart of Accounts; and Article 43, that the GDA, among others, should prepare the GFS for the public sector.

Article 4 of the Basic Norms of Public Credit states its scope of application; Article 8, that operating units in the MOF will follow up and assess the public credit operations; Article 11, that the CBB will perform the official recording of the external public debt; Article 17, the definition of public debt, which includes emission of securities, loans, accounts payable, and other debts; Article 18, the definitions of domestic and external debt, and short-term and long-term debt; Article 20, that the management of public credit operations should be through the Debt Management and Financial Analysis System (DMFAS); and Article 49, that the DMFAS, which is under the control of the CBB, should be linked to the integrated accounting system.

Article 12 of the Law No. 2028 states, among others, that every municipal council has to review, approve, or reject the report of the budgetary programming and execution, financial statements, and annual publication presented by the Mayor three (3) months after the end of the reference fiscal year. Article 106 states that the Mayor will design and implement the municipal annual operating program and budget taking into account regulations and procedures established by the Law of Government Administration and Control; and Article 110 states that the municipal accounting will be based on the principles of the integrated accounting with uniformity in the codification and administrative procedures.

\footnotetext{
${ }^{5}$ The fiscal year goes from January 1 to December 31 .
} 
The Decree 25875 created the SIGMA, which comprises of the budgetary, accounting, treasury, public credit, and other relevant subsystems, basic standards, and administrative procedures that every public entity of central government takes into account to program, manage, record, monitor, and assess its revenue and expenditure. The SIGMA was developed, among others, to produce timely and reliable data of the central government operations, and it is the primary source of information for the compilation of budgetary data and GFS.

Additionally, Article 21 of the Organic Law No. 1670 states that the CBB will keep the records of public and private external debt and, in its Article 43 states that the CBB will publish, periodically, statistical and economic information on economic and financial indicators within its scope of competency. The Directory Resolution No. 113/2003 states that the $\mathrm{CBB}$ will follow up any new external debt and will record it in the DMFAS. Article 18 states that the CBB will manage the DMFAS to produce periodical statistical information of external debt and will provide to the MOF with summaries of the public external debt 20 days after the end of the reference month. Article 21 stipulates the publication of information on External Debt through monthly, quarterly, and annual publications, and the CBB website. The CBB compiles and disseminates data for the public sector.

The DL No.14100 created the NSI to collect, to assess, process, and provide statistical information to guide the socio-economic development of the country. Article 2 states that the NSI is comprised by individuals and public and private entities that carry out statistical activities or compile relevant data. Article 14 states, among others, that the institutions included in the SNIE should not produce statistical information and not disseminate their statistical work without the authorization of the National Council of Statistics.

The Law No. 27329 states that all Bolivian citizens have access to official information as a right and a requirement for the functioning and strengthening of the democracy. In the Constitution, Article 146 states that the Executive Branch sets up the regulations and the procedures for the preparation and the presentation of the public sector budgets. Working arrangements for compilation of GFS in the MOF are consistent with the assignment of collection, compilation, and dissemination responsibilities.

\subsubsection{Data sharing and coordination among data-producing agencies are adequate}

Data sharing and coordination between the UPF and the Public Debt Directorate in the MOF, and between the UPF and the Fiscal and Monetary Sector (SSMF) and the External Sector (SSE) Deputy Management Offices of the Economic Policy Advisory Office (APEC) in the $\mathrm{CBB}$ are adequate. Working arrangements to ensure regular reconciliation of above-the-line data compiled by the UPF in the MOF and the financing data compiled by the Fiscal and Monetary Sector in the CBB are in place. Financing data compiled by the UPF are used to validate or complement those compiled by the CBB. Similar procedures are observed for the reconciliation of GFS with balance of payments. The NSI uses GFS compiled by the UPF as an input to produce national accounts. A reconciliation exercise between these two macroeconomic datasets is not performed. 
Data sharing and coordination between the UPF and the budgetary and accounting viceministry in the MOF could be improved. At present, the budgetary and accounting systems record on line operations of the central administration and some decentralized public institutions, regional governments, large local governments and nonfinancial public corporations through the SIGMA. Some small local governments' operations are recorded through the Integrated Accounting System (SINCON). ${ }^{6}$ The rest of the nonfinancial public sector's operations are recorded through its own management systems.

Recommendation: Improve intra and inter-agency data sharing and coordination between the MOF and data-producing public entities.

\subsubsection{Individual reporters' data are to be kept confidential and used for statistical purposes only}

The confidentiality of data reported to the MOF is protected by the following legal framework: (1) the Decree No. 14100 (Decree of the SNIE ${ }^{7}$ ) in its Article 21, which states that data and information collected by the SNIE are confidential, should be used exclusively for statistical purposes, and should not be disseminated on an individual way; and (2) the Internal Regulation of the MOF in its Articles 39 and 44. Article 39 states that it is prohibited to provide confidential information and documentation without a management approval and Article 44 indicates that an unauthorized disclosure of confidential information of the MOF or entities under its control could result in dismissal from the civil service. Also, confidentiality is guaranteed by the following: (1) data sources are restricted to MOF staff that uses this information for performing their statistical duties; (2) access to the MOF building where confidential data are stored is restricted; and (3) computing systems have security systems, such as passwords.

\subsubsection{Statistical reporting is ensured through legal mandate and/or measures to encourage response}

The statistical reporting is ensured through a comprehensive legal framework and measures to encourage response. Article 11 of Law No. 2042 states that all public entities and all units that receive transfers from the Treasury have the obligation to report to the MOF information used to follow up and assess the budget program and execution, and financing and debt. The budget execution information, which includes revenue, expense and public investment data, should be reported to the MOF, specifically to the GDA, ten days after the end of the reference month. Additionally, information of public investment should be reported to the

\footnotetext{
${ }^{6}$ The SINCON is an accounting system control by the GDA. It is a simpler system than the SIGMA and it is used to collect financial data of small local governments.

${ }^{7}$ The MOF belongs to the SINE.
} 
Vice Ministry of Public Investment and External Financing. Failure to report data to the MOF carries sanctions, such as: (1) the Vice Ministry of Treasury and Public Credit will discontinue Treasury transfers and immobilize resources in the financial system, and (2) the Vice Ministry of Budget and Accounting will not receive requests for budgetary modifications and the statements of payments. Also, Article 33 establishes that, from the beginning of the financing operations, national, departmental, and municipal public entities should provide relevant information about these operations to the Vice Ministry of Treasury and Public Credit. Also, through this article, debt (financing) includes direct and indirect debt, and short, medium, and long-term contingencies with several creditors, such as private sector, public sector, resident, or non-resident individuals. This definition of debt also includes accrual expenses, i.e., expenses which were not paid at the end of the fiscal year. Finally, Articles 42 and 43, modified by the Law on Modification to the Law No.2042 ${ }^{8}$ (Law No. 2137 of October 23, 2000), state that central administration financial statements should be presented to the President, for his consideration and to be submitted to the Congress 180 days after the end of the reference fiscal year. These financial statements will include information of operations performed until April 30 of the reference fiscal year.

Article 5 of Regulation Decree on Responsibility for the Public Function (Decree No. 23318-A of November 3, 1992) states that public officials should perform their activities on a transparent way and that they will, among others: (1) disseminate information, before, during, and after the execution of their acts to provide an adequate understanding of the resources allocation and use, main outcomes, and factors that affected outcomes; and (2) provide information already processed to any individual and entity on demand.

Article 44 of the Law No. 2028 mandates, among others, to disseminate and to publish, at least once a year, municipal reports with financial and nonfinancial information.

Article 39 of the Resolution No. 222957 states the list of financial statements (balances, statement of resources and expenses, statement of cash flows, statement of changes in the net worth, statement of budget execution for resources and expenses, and others) to be presented to the GDA, and Article 48, the timing (three months after the end of the reference year) for the mandatory reporting of financial information to the GDA.

Directory Regulation No. 113/2003 states in its annex that the CBB will require: (1) from the MOF, a timely reporting of the debt (loan) contract and legal provisions that authorize external financing to any public and private entity that used government guarantee; (2) from the private entities that obtain external financing with government guarantee, the submission of a copy of debt contract and additional relevant documentation; and (3) from the creditor, the submission of statements and liquidations of the debt service.

\footnotetext{
${ }^{8}$ The Law of Budgetary Administration.
} 


\section{$0.2 \quad$ Resources}

\subsubsection{Staff, facilities, computing resources, and financing are commensurate with statistical programs}

Staff of the UPF involved in the collection, compilation, validation, and dissemination of $\mathrm{GFS}^{9}$ are one general director, two directors, five professional specialists that include area responsible analysts and specialized professional analysts, 25 professional analysts, and five nonprofessional analysts. Some professional analysts work in departmental locations outside the UPF headquarters. The number of staff, qualifications, and salaries are adequate to perform the current statistical activities, but not to perform new collection, compilation, and dissemination tasks to improve GFS quality, such as an expansion of the institutional and transaction coverage of the GFS already compiled, and the implementation of the Government Finance Statistics Manual 2001 (GFSM 2001) analytical framework. MOF staff has participated in GFS courses held at the IMF headquarters and also in regional courses on the GFSM 2001 methodology. Additional training in GFS methodology is provided internally by mentors assigned to new personnel and by attending training courses and seminars in domestic institutions. The staff turnover is manageable because most of the officials have been working in the UPF for more than five years. There are nonformal measures in place to encourage the retention of experienced staff. Salaries of the managers and analysts are competitive with those received in other public institutions.

Available computer resources are adequate. These resources include 38 personal computers and two mainframe. Computers have access to Internet, and the available software, such as Excel and Word, is adequate for current needs. Each official has his/her own computer. The UPF has a unit in charge of information and computing matters. This unit has created a system for the aggregation and consolidation of nonfinancial public sector operations. Currently, this system is being updated. Also, this unit provides anti-virus, updates software, and keeps back-up of the GFS produced in the UPF.

Physical facilities and financial resources appear to be adequate for current GFS collection, compilation, and dissemination. With increased future GFS activities, such as those mentioned in the first paragraph of this indicator, funding may be insufficient.

Recommendation: Allocate additional personnel, computing, and financing resources to perform new collection, compilation, and dissemination tasks to improve GFS quality, such as an expansion of the institutional and transaction coverage of the GFS already compiled, and the implementation of the GFSM 2001 analytical framework.

\footnotetext{
${ }^{9}$ Functions of UPF staff also include answering questions of GFS users.
} 


\subsubsection{Measures to ensure efficient use of resources are implemented}

Article 9 of Law No.1178 states that the System of Personnel Administration, promoting efficiency, will determine the working positions and financial means to obtain these positions, and implement mechanisms for personnel assessment and training.

Annual assessment of staff performance is conducted based on Article 27 of Law on Public Officials of October 27, 1999 (Law No. 2027). This article mandates programming and implementing performance assessment processes to all public sector staff. The assessment produces a report with ratings obtained by each official through her/his evaluation. This report is provided to the official assessed for her/his information and stored in the administrative personnel files, but it is not used for promotion and salary increases. The MOF has calculated the costs or carried out budgeting exercises associated to the GFS compilation.

\subsection{Relevance}

\subsubsection{The relevance and practical utility of existing statistics in meeting users' needs are monitored}

The MOF has not undertaken specific and formal actions, such as surveys, to obtaining feedback on the relevance and practical utility of fiscal data for analytical purposes and research to identifying new and emerging data requirements. However, the authorities have encouraged the participation of the UPF in statistical meetings and seminars and make efforts to keep close contacts with users to ensure that GFS meet users' needs.

Recommendation: Make more systematic efforts to identify new and emerging data requirements and undertake surveys to obtain feedback about the relevance and practical utility of fiscal data.

\subsection{Other quality management}

\subsubsection{Processes are in place to focus on quality}

The UPF has posted on the MOF website its institutional mission and vision indicating its recognition to data quality. The UPF mission is "the elaboration and the follow-up of the Government Fiscal Programming, providing reliable and timely information for decision making to the authorities, through the collection and the compilation of economic and financial information, and programs of improvement and prevention for the public sector institutions. Additionally, the UPF coordinates with the CBB and other entities involved in the fiscal area," and its vision indicates that "the UPF is a dynamic and transparent institution known for its specialization in the production of information and timely fiscal counseling" (See http://www.upf.gob.bo/M1200.htm).

In general, the MOF is fully aware that quality should be the cornerstone of the budgetary, accounting, and statistical processes. To this end, major efforts have been put in place during 
the last years to collect, compile, and disseminate a more complete set of fiscal data (GFS, budgetary and accounting data) with increased coverage of institutions and transactions. There is recognition of the trade-off involved in the data compilation, such as between timeliness and accuracy.

\subsubsection{Processes are in place to monitor the quality of the statistical programs}

Some mechanisms are in place to ensure increasing quality in the compilation of the GFS, such as the review and revision of preliminary data, periodic visits of UPF analysts to data providers, assessment of data collection and compilation processes, and cross-checking data sources.

\subsubsection{Processes are in place to deal with quality considerations in planning the statistical program}

There are medium term plans to improve data quality. These plans include actions to improve institutional coverage, statistical presentation of the publications, and additional training, and an ongoing familiarization with the GFSM 2001 analytical framework for compiling GFS.

\section{Assurances of integrity}

\subsection{Professionalism}

\subsubsection{Statistics are produced on an impartial basis}

Although the impartial collection, compilation, and dissemination of GFS are not supported by specific laws or other formal provisions for professional independence, there is no evidence that such data are not compiled on an impartial basis. A culture of professionalism is clearly recognized as essential to the credibility of statistical results in the internal provisions of the MOF and in the principles of the Law on Public Officials of October 27, 1999 (Law No. 2027) and its by-laws and provisions.

The choice and tenure of the managers are based on an independent process. Thus, the possibility of interference is highly limited. More importantly, professionalism is a key factor in the recruitment and promotion of staff. Articles 23 and 31 of Law No. 2027 state that staff recruitment and promotion will be through a selection process involving principles of merit, competency, and transparency and procedures that guarantee equity of conditions for selection; and promotion processes will be based on equality of opportunity, capacity of performance and transparency.

Efforts are made to promote professionalism by sending staff to training courses abroad and on-the-job training. Also, professionalism is fostered by analytical work, publication of methodological papers, and organization of lectures and seminars. Research and analysis are encouraged, and the result of these academic activities is published on the MOF website. 
1.1.2 Choices of sources and statistical techniques as well as decisions about dissemination are informed solely by statistical considerations

No evidence exists of political interference in the choice of data sources and statistical methods and decisions about dissemination. Data sources are selected according to the usefulness and availability of the information to compile sound GFS. Also, changes to the analytical framework and decisions on dissemination are based solely on statistical reasons.

\subsubsection{The appropriate statistical entity is entitled to comment on erroneous interpretation and misuse of statistics}

The MOF is empowered to respond to misinterpretation/misuse of fiscal data, in which case, it will prepare and disseminate explanatory notes to help correct the mistakes/misuses of fiscal data and provide an account of recent developments in annual and subannual reports.

\subsection{Transparency}

\subsubsection{The terms and conditions under which statistics are collected, processed, and disseminated are available to the public}

The broad legal framework for collection, compilation, and dissemination of the fiscal data is specified in relevant laws (see 0.1.1 indicator), which are available to the public.

\subsubsection{Internal governmental access to statistics prior to their release is publicly identified}

No official agency outside of the MOF has access to data prior to publication. Procedures for authorizing dissemination of GFS, deemed to be internal, are made public only in a limited manner. The Minister or Vice Minister of the MOF authorizes the release of GFS.

\subsubsection{Products of statistical agencies/units are clearly identified as such}

All fiscal data products that are disseminated through the MOF website and Statistical Bulletin, but they do not clearly identify the producing agencies and data sources.

Recommendation: Clearly identify data sources and the entity in charge of data compilation in all statistical products.

1.2.4 Advance notice is given of major changes in methodology, source data, and statistical techniques

Advance notice is not given to the public about major changes in the methodology or other relevant changes that materially affect the GFS, such as improvements in the institutional and transactions coverage. No explanatory notes are provided when the changes are introduced in publications. 
Recommendation: Provide advance notice of all methodological and other relevant changes that materially affect the GFS.

\subsection{Ethical standards}

\subsubsection{Guidelines for staff behavior are in place and are well known to the staff}

The ethical standards guiding staff behavior are contained in the Law No. 2027, Chapter III, and the Ministerial Resolution on Internal Regulation of the MOF Personnel (Ministerial Resolution No. 1268 of October 13, 1999). Article 12 of Law No. 2027 establishes that public service is based on principles and ethical values of integrity, impartiality, probity, transparency, responsibility, and efficiency; Article 13 states that public entities should promote conduct policies and norms based on ethical principles and values, and adopt an Ethical Code; Article 14 states that public officials cannot receive gifts, presents, or benefits oriented to favor, directly or indirectly, his/her working functions; and Article 17 establishes a disciplinary regimen which will be in charge of situations that are opposite to this law. Article 53 states that, for all public officials, it is mandatory to present a declaration of goods and rents possessed at the beginning of his/her functions, and Article 55 states that the Comptroller will direct and control the system of declaration of goods and rents. Article 38 of Ministerial Resolution No. 1268 establishes ethical norms for MOF public officials.

MOF staff is generally aware of ethical provisions that regulate their work.

\section{Methodological soundness}

\subsection{Concepts and definitions}

2.1.1 The overall structure in terms of concepts and definitions follows internationally accepted standards, guidelines, or good practices

GFS concepts and definitions are broadly consistent with the recommendations of the GFSM 1986 analytical framework. The authorities have not yet prepared a plan to migrate to the GFSM 2001. The GDA prepared bridge tables between the budgetary and accounting national classifications and those specified in the GFSM 2001 and compiles GFS for publication in the IMF's GFS Yearbook. The preparation of these bridge tables and GFS compilation are not coordinated or reconciled with data compiled by the UPF.

Recommendation: Develop a plan to migrate to the GFSM 2001 analytical framework. Current GFS compilation using the GFSM 2001 methodology by the GDA should be coordinated among relevant units and institutions involved in the GFS compilation. 


\section{$2.2 \quad$ Scope}

\subsubsection{The scope is broadly consistent with internationally accepted standards, guidelines, or good practices}

The institutional scope of the GFS ${ }^{10}$ covers partially the units of the nonfinancial public sector and its subsectors (general government and nonfinancial corporations as defined by the authorities). This scope is not in line with the recommendations of the GFS manuals because subsectors of general government do not include consolidated accounts for the central government as recommended by the GFSM 1986 or 2001 analytical frameworks.

For some decentralized units, the data on operations (flows) reported to the MOF are not available. For these units, the UPF only records as revenue and expense (either as a current or as a capital expense) the government transfers. As a result of this procedure, it is assumed that these units do not register deficit or surplus balances. Although these government transfers represent an important percentage of the decentralized unit revenue, there are other sources of revenue, such own resources, grants, and disbursements that are not recorded.

For local governments, the data on operations (flows) reported to the MOF are incomplete. The data reported or collected include information of 130 municipalities, of a total of 329, which represent 70 percent of the total resources. The information for the remaining 199 municipalities is estimated using the government transfers (revenues) and distributed by expense categories using the expense structure of the municipalities that report data. For domestic debt (stocks), data are not collected due to legislation constraints. ${ }^{11}$

The presentation of GFS compiled by the UPF broadly follows the Summary Table of Major Components in the GFSM 1986. In addition, disseminated tables for the consolidated general government and consolidated nonfinancial public sector follow the format of tables A (government revenue and grants) and $\mathrm{C}$ (economic classification of expenditures without lending minus repayment). There are no tables for functional classification of expenditures, financing by type of debt instrument (tables B and E), and debt data in the reports compiled and disseminated by the UPF.

Debt data, external and domestic, are compiled and disseminated by the CBB. The external debt is presented by creditor and subsectors of public sector; and domestic debt is presented by financial instrument, term, and currency. The domestic debt includes only securities

\footnotetext{
${ }^{10}$ In the UPF-MFO's website and hard-copy publications.

${ }^{11}$ According to the Constitution and the Law of Municipalities, the municipalities have execution, normative, administrative, and technical autonomy. This autonomy is carried out, among others, through the programming and execution of legal, administrative, technical, economic, financial, cultural and social procedures. Currently, the MOF is developing a performance project to improve, among others, collection and compilation of flow and stock data of regional and local governments.
} 
issued by the Treasury. This data do not include local government debt, floating debt, fiscal tax certificates, and other securities, such as deposit refund certificates. The General Directorate of Public Credit compiles data on domestic debt for internal use.

Recommendations: (1) Expand the scope of institutions and transactions in the GFS to include comprehensive and detailed data of the operations of some decentralized agencies and local governments; (2) make special efforts to compile debt data of local governments; and (3) expand coverage of domestic debt.

\subsection{Classification/sectorization}

\subsubsection{Classification/sectorization systems used are broadly consistent with internationally accepted standards, guidelines, or good practices}

For compilation of GFS, the UPF prepares the sectorization of the public sector operations at two levels: (1) the general government, which consolidates data of central government (as defined by the authorities), regional governments, local governments, and social security funds; and (2) the nonfinancial public sector, which consolidates data of general government and data of several nonfinancial public corporations.

The consolidated central government sector (as defined by the authorities), which consolidates data of the treasury, some decentralized units, universities, and units of the MOF, such as the Vice-Ministry of Public Investment and External Financing, but do not include social security funds, does not follow international recommendations.

Data reported on the regional government sector includes data of all regional/departmental (10 regional/departmental) governments; the local government sector includes data of only 130 municipalities, as indicated previously; and the social security fund sector includes data of three funds of a total of four funds that should be included: the National Fund of Health, the Petroleum Fund of Health, and the National Institute of Insurance of Health. Therefore, the local government and social security subsectors do not present a complete transaction or institutional coverage, respectively.

Contrary to recommendations in the manuals, the GFS compiled by the UPF have the following shortcomings: (1) statistics on the consolidated central government are not prepared; and (2) statistics on the social security sector do not include detailed data of the Corporation of Military Social Insurance. ${ }^{12}$ To amend these shortcomings, the GFS manuals recommend the compilation of statistics on (1) the central government, excluding all public corporations; (2) the consolidated central government, including the central administration, social security schemes, and decentralized entities; (3) the consolidated general government

\footnotetext{
${ }^{12}$ The GFS compiled by the UPF only included data on expenses for pensions of the Corporation of Military Social Insurance. These pensions are paid using central government financial resources.
} 
including the consolidated central government, as defined by the GFSM 2001 analytical framework, and local governments; and (4) the consolidated nonfinancial public sector, including the consolidated general government and the consolidated nonfinancial public corporations.

Revenue data are classified as: (1) current revenue, which includes tax revenue, sales of oil products, sales of other public corporations, current transfers, and other current revenue; and (2) capital revenue. Contrary to recommendations in the GFS manuals, (1) the tax classification used to present this information does not follow international recommendations; (2) taxes include royalties; (3) tax refunds are not subtracted; (4) other revenues include "repayment of loans," which is an expense category; and (5) other capital revenue does not include two categories of capital revenue currently classified as current revenue ("other capital revenue" and the part corresponding to capital revenue currently classified in other revenues).

Expenditure data are classified as: (1) current expenditure and (2) capital expenditure. Current expenditure is classified by personnel services, good and services, external debt interest, domestic debt interest, current transfers, other current expenses, and expenses not identified. Contrary to recommendations in the GFS manuals, (1) the personnel services include social assistance benefits; (2) interest includes commissions; (3) current transfers include tax refunds; (4) other current expenses include expense data by institutional units instead of economic categories; and (5) expenditures do not include a net category, lending minus repayment, because repayment is included as revenue category.

A separated category for pensions is included, which presents data disaggregated by current revenue and expenses. Regarding this category, the GFSM 2001 recommends to compile payments to pension funds as a category of expense, specifically as compensations of employees.

The financing is classified by (1) net external credit, which includes (a) disbursements, (b) amortizations, (c) interest not paid, (d) arrears, (e) HIPC debt relief, and (f) others, which include deposits of a nonfinancial public corporation and capitalizations; and (2) net domestic credit, which includes (a) central bank, (b) providers, (c) floating debt, and (d) others, which include securities, such as fiscal certificates, bonds of the pension administration funds, non current deposits, and others. The floating debt includes the difference between expense on accrual basis and expense on a cash basis. Currently, Bolivia has not arrears and interest not paid is zero.

External debt is classified by debtor and payer, identifying breakdowns for the nonfinancial public sector and the financial public sector. The nonfinancial public sector includes a breakdown for central government, local governments, nonfinancial public institutions, public and public-private corporations. The MOF also prepares a table for external debt by creditors, i.e., international organizations and foreign governments. There is no compilation of external debt data by financial instrument, or domestic debt data by debt holder. 
The UPF does not compile a functional classification for expenditures, which is compiled by the DGA for GFS reporting for publication in the IMF's GFS Yearbook.

Recommendation: Adopt sectorization and classification systems recommended in the GFS manuals, including:

- Compile and disseminate data for central government including budgetary, extrabudgetary, and social security operations.

- Compile GFS for central government excluding data of the FNRD, which should be classified in the financial corporations sector.

- Compile GFS for the social security sector, including detailed data of the Corporation of Military Social Insurance.

- Reclassify royalties as other revenue item; commissions for interest as goods and services item; tax refunds as a revenue item; social assistance benefits as transfers to households; repayments as an expense item and present a net item, lending minus repayments; and payments for pensions as compensation of employee item.

- Reclassify as other capital revenue two categories wrongly classified as current revenue, "other capital revenue" and the part corresponding to capital revenue in "other revenues."

- Collect and compile disaggregated data for some items included in expenses, such as "universities" and "others," to obtain an adequate economic classification.

- Classify tax revenues, financing, and debt by instrument, holder and maturity following the recommendations of the GFS manuals.

\subsection{Basis for recording}

\subsubsection{Market prices are used to value flows and stocks}

All cash transactions reflect actual prices. In accordance with the GFSM 1986, domestic debt is recorded at face value (i.e., the undiscounted amount of principal to be repaid at the end of the contract), but external debt is not. External debt is recorded at nominal value (i.e., the amount that the debtor owes to the creditor at any moment and reflects the value of the instrument at creation and subsequent economic flows.) The GFSM 2001 recommends to value flows and stocks at market prices.

Recommendation: Value public external and domestic debt at face value if the GFSM 1986 methodology is used or at market prices if the GFSM 2001 methodology is used. Nominal values can be shown as memorandum items. 


\subsubsection{Recording is done on an accrual basis}

The UPF compiles GFS on a mixed basis: revenue on a cash basis and expenditure and financing on a mixture of cash and noncash bases.

Outstanding debt balances are recorded in the DMFAS using the original currency and converted to U.S. dollars using an exchange rate fixed for the reference period.

Disbursements are recorded at the date of the creditor's disbursement, and payments of the debt services are recorded at the date of the payment by the CBB.

Recommendation: Compile GFS data on noncash and cash bases. Both bases of recording are relevant for policy analysis and they should be consistent.

\subsubsection{Grossing/netting procedures are broadly consistent with internationally accepted standards, guidelines, or good practices}

Some transactions that should be shown on a net basis, in line with the GFSM 1986 and the GFSM 2001, are shown on gross basis, such as lending minus repayment. Tax refunds should be shown on a net basis in each corresponding tax category instead of an expenditure category.

Recommendation: Include tax refunds in the taxes, netted from the corresponding tax, if possible; while lending minus repayment should be included as an expenditure category (when using the GFSM 1986 methodology).

\section{Accuracy and reliability}

\subsection{Source data}

3.1.1 Source data are obtained from comprehensive data collection programs that take into account country-specific conditions

The process of GFS compilation comprises two stages. In the first stage, the Area of Statistics and Consolidation of the UPF collects and compiles cash flows of the consolidated nonfinancial public sector. In the second stage, the Area of Analysis and Follow-up of the UPF incorporates some adjustments to approach the cash data to the accrual recording, and also includes data on floating debt. Also, in this second stage, the UPF reconciles GFS above-the-line with GFS below-the-line produced by the CBB.

The main data sources for the first stage are diverse; they include administrative systems for monitoring the budget execution and accounting. These systems are: the SIGMA, the SINCON, and some integrated systems of public units. In addition to these systems, the UPF has developed a system to collect timely data that are not available through the systems previously mentioned. Among these systems, there are no interphases to reconcile data and 
guarantee consistency. Also, since these systems are not integrated, a duplication of collection and compilation efforts has emerged.

Recommendations: Allocate financial, human, and computing resources to integrate and standardize data sources for improving consistency of the GFS and to reducing the collection and compilation burden.

The SIGMA and the SINCON are controlled by the GDA. These data sources provide financial information on a whole range of economic flows and stocks of the central administration, some decentralized entities, and some local governments. The SIGMA and SINCON produce budgetary execution reports and financial information (balance) reports. Data on other operations of some decentralized entities and public corporations are provided directly to the MOF in diskettes or hard copies.

From the budgetary execution information, the UPF processes information of (1) units that use, online, a unique and standardized format, the budgetary execution reports, prepared by the GDA for the SIGMA and the SINCON; (2) units that use a format, known as "effective operations of cash," prepared by the UPF through the system that this unit has created for data collection purposes; and (3) units that report using formats provided for their own administration systems.

Recommendation: Expand the institutional coverage of the SIGMA to include information collected by the SINCON and other financial systems.

The financial information formats used to collect data online are comprehensive and include sufficient detail to enable a proper collection and classifications of fiscal data on cash and accrual bases. The online and hard copy formats are easily accessible and provide clear instructions, but the timeliness of these data is less than those collected by the UPF. These formats are used to compile financial data under the GFSM 2001 analytical framework.

Due to the fact that the budgetary execution reports are the main source used by the UPF for the compilation of above-the-line data, the information is on a cash basis. The two main formats of the budgetary execution reports are the revenue execution and the expenditure execution by object. In this first stage, the UPF also compiles below-the-line information, but it is only used to validate financing data provided by the CBB.

The data sources for financing (below-the-line data) are coming from the DMFAS and CBB balances. The DMFAS covers detailed information on domestic and external debt and are shared by the MOF and the CBB. The $\mathrm{CBB}$ is responsible for the compilation and dissemination of the internal financing and debt.

The data sources for domestic financing and debt are (1) the MOF's Integrated Financial Information system of the Treasury; (2) the data compiled by the CBB's Open Market Operation Manager Office; and (3) data from the CBB-COIN accounting system for pension administration funds. 


\subsubsection{Source data reasonably approximate the definitions, scope, classifications, valuation, and time of recording required}

\section{Scope}

The MOF has two versions for the sectorization of the economic units, one prepared by the UPF for compilation of the GFS, as described in 2.2.1, and the other included in the budget institutional classification. The second version prepares the sectorization of the nonfinancial public sector at three levels: public administration, territorial administration, and nonfinancial public corporations and, reasonably approximates to the institutional coverage and sectorization recommended by the GFS manuals. Public administration includes central administration, national services and deconcentrated entities, decentralized public institutions without corporation purposes, and social security institutions; territorial administration includes regional governments and local governments; and nonfinancial corporations includes national corporations, regional corporations, and local government corporations. This institutional classification is used in the accounting system, and also for the SIGMA, and it is adjusted for compilation of GFS by the UPF. These adjustments are included in dimension 2 of this report.

\section{Classification}

The SIGMA, the SINCON, and some decentralized unit systems use their own classifications, i.e., the budgetary classification, and the chart of accounts. The budgetary classification for revenue and expenditure - the source - is broadly aligned with the GFSM 1986 (the main exceptions are the classification by instruments for the financing data). A similar situation is observed in the accounting classification, where these classifications broadly follow international accounting standards. For the compilation of internal and external debt, the DMFAS uses mostly the classifications recommended in the GFSM 1986. The UPF is aware of the different practices, i.e., basis of recording and institutional coverage, between primary sources of data and GFS and makes adjustments accordingly.

\subsubsection{Source data are timely}

Article 11 of Law No. 2042 states that the public units should report financial data (i.e., budgetary, financial, and patrimonial data) to the DGA in the MOF with a ten day lag after the end of the reference month.

In practice, the data of units collected through the SIGMA and the SINCON are timely because these systems are automated. For other units, mainly for some decentralized entities such as departmental governments and nonfinancial enterprises, the UPF has implemented some administrative procedures to cope with these delays, and some improvements have been observed. 


\subsection{Assessment of source data}

3.2.1 Source data-including censuses, sample surveys and administrative records-are routinely assessed, e.g., for coverage, sample error, response error, and nonsampling error; the results of the assessments are monitored and made available to guide statistical processes

Verification procedures are in place to assess the accuracy of the data in the SIGMA, the SINCON, and the DMFAS. There is some control of the administrative process developed by the UPF staff, including the review of data consistency in the SIGMA and the SICON. The results of assessments are monitored or used to guide planning. The GDA has not assessed the accuracy of the reported data, and therefore it is not aware of the degree of misreporting in the data sources. Generally, there is an appropriate balance between accuracy and timeliness in the production of data. The UPF publishes preliminary data as soon as the data are reasonably complete. Preliminary estimates are replaced with final data when these data have been produced. The status of the data used for each period is noted in the disseminated GFS.

\subsection{Statistical techniques}

\subsubsection{Data compilation employs sound statistical techniques to deal with data sources}

Statistical techniques such as derivation, consolidation, aggregation, valuation, conversion to domestic currency, preparation of balance indicators, bridge tables between data sources and GFS, and estimation of GFS are sound.

\subsubsection{Other statistical procedures (e.g., data adjustments and transformations, and statistical analysis) employ sound statistical techniques}

Generally accepted statistical methods are used to adjust data sources to GFS compilation. As it was mentioned above (indicator 0.4.2), the UPF compiles GFS in two stages. Therefore, the adjustments to the data sources are different in each stage. In the first stage, the UPF uses conversion tables between data sources, mainly budgetary execution reports, and formats known as "effective operation of cash." Then, the UPF converts all the "effective operation of cash" to a format called "Government Finance Statistics" on a cash basis. In the second stage, the "Government Finance Statistics" formats are converted, after several adjustments, to the GFS on a mixed basis, that is called the "Fiscal Programming" data by the authorities.

During the first stage, adjustments are to revenues, because the "effective operation of cash" presents more categories than those included in the budgetary execution reports. In the second stage, the UPF adjusts the data received from the first stage. The adjustments are to some above-the-line categories to place them in a noncash basis of recording; to increase the transaction coverage by including operations, such as domestic and external deposits of nonfinancial corporations not recorded in the CBB's accounts, some grants, and some resources of regional governments and universities; to include information about securities, 
the fiscal certificates used for tax refunds and to pay services provided to the government; to include information regarding the floating debt; to compensate delays in the administrative recording of information, i.e. when taxes collected are deposited but not recorded in the accounts; and to match the amount recorded as a transfer by the resources provider with the amount recorded as a transfer by recipient (mainly it happens in the co-participation of taxes between central and local/regional governments).

\subsection{Assessment and validation of intermediate data and statistical outputs}

\subsubsection{Intermediate results are validated against other information where applicable}

The GFS are based on budget and accounting data. Budgetary data are validated against accounting data. Banking statements are reconciled against the data prepared or collected for this purpose in the MOF. Cross-checking with the CBB on changes in deposits is performed. Financing and debt stock data compiled using information in the accounting systems are not fully validated against the data in the DMFAS.

\subsubsection{Statistical discrepancies in intermediate data are assessed and investigated}

All discrepancies between GFS and budgetary data and those between the budgetary data and accounting series are investigated.

\subsubsection{Statistical discrepancies and other potential indicators of problems in statistical outputs are investigated}

In the event of large fluctuations in GFS, the UPF has established procedures to investigate classification or sectorization errors. Also, the UPF-MOF and the CBB make efforts to reconcile reported financial flow data on financial assets and liabilities with the corresponding stock data.

\subsection{Revision studies}

\subsubsection{Studies and analyses of revisions are carried out routinely and used internally to inform statistical processes (see also 4.3.3)}

The GFS data sources are collected within two weeks after the end of the reference month and one additional week is used for cross-checking and validation of data sources. Another week is used by the GFS compilers to introduce some adjustments and to reconcile these data with financing data produced by the CBB. These data are published first as preliminary. Final data are published following revisions. Generally, revised data are published in the next publication.

Findings of revisions are studied and taken into account to improve data compilation, but are not documented. Revisions produce routine replacement of preliminary with final data. 
Recommendation: Document revision studies and analyses of revisions.

\section{Serviceability}

\subsection{Periodicity and timeliness}

\subsubsection{Periodicity follows dissemination standards}

Periodicities of the data disseminated on general government operations and central government debt data meet GDDS recommendations.

\subsubsection{Timeliness follows dissemination standards}

Timeliness of the data disseminated on general government operations and central government debt data meets GDDS recommendations.

\subsection{Consistency}

\subsubsection{Statistics are consistent within the dataset}

Concepts and definitions, and classifications for producing sub-annual GFS are the same, therefore, consistency in the datasets is ensured. Although the CBB is in charge of compiling and disseminating financing data for general government and nonfinancial public sector operations, the MOF compiles financing data for these sectors to be used in reconciling fiscal and monetary data. Discrepancies between above-the-line and below-the-line data are assessed below.

\subsubsection{Statistics are consistent or reconcilable over a reasonable period of time}

GFS are consistent with expected trends and reflect discretionary changes, external shocks, and developments of economic activity. Consistent historical data (since 1990 for general government and nonfinancial pubic sector) are published on the Statistical Bulletin of the MOF. Some GFS time series are also presented on the MOF website. The UPF is aware of the need to explain and document changes on the time series, and when events affected time series, they were annotated and published.

\subsubsection{Statistics are consistent or reconcilable with those obtained through other data sources and/or statistical frameworks}

Even though the MOF is the main provider of fiscal data to the NSI for the compilation of the national accounts, no efforts are made to reconcile these two datasets. There are discrepancies due to differences in the basis of recording and institutional coverage. The 1993 SNA recommends using expenditure on an accrual basis to compile national accounts, the UPF-MOF compiles fiscal data on a cash basis and the GDA-MOF compiles data on cash 
and accrual bases. The NSI use data from these two units, the UPF and the GDA, to compile government sector data of the national accounts.

The monetary statistics and GFS are regularly reconciled. The institutional coverage, the exchange rate, and the basis of recording used for compilation of above-the-line data by the MOF and financing by the CBB are the same. Currently, changes in nonfinancial public sector deposits are cross-checked with deposits in depository corporations.

Although the BOP and GFS use the same data source (the DMFAS), no formal reconciliation is undertaken by the MOF and the $\mathrm{CBB}$. Key variables that should be reconciled include external transfers and capital and external financing.

The GFS on cash and noncash basis compiled by the UPF-MOF and those on an accrual basis compiled by the GDA-MOF are not reconciled.

Recommendation: Reconcile GFS with national accounts to ensure consistency.

\subsection{Revision policy and practice}

\subsubsection{Revisions follow a regular and transparent schedule}

Although revisions follow a regular schedule and this well established practice is known by users, this information is publicly disseminated.

Recommendation: Make the revision schedule known to the public.

\subsubsection{Preliminary and/or revised data are clearly identified}

Preliminary and final data are adequately noted in publications for flows and for external public debt. Both are disseminated with the same detail and through the same media.

\subsubsection{Studies and analyses of revisions are made public (see also 3.5.1)}

Revisions consist mainly in replacing preliminary by final data. Although revision studies and analyses are undertaken, these are not made public.

Recommendation: Include explanatory notes of revisions in published tables and disseminate studies and analysis of revisions. 


\section{Accessibility}

\subsection{Data accessibility}

\subsubsection{Statistics are presented in a way that facilitates proper interpretation and meaningful} comparisons (layout and clarity of text, tables, and charts)

Although the disseminated GFS permit identification and comparison of major aggregates of flows, there is room for improvement. For example, data sources and units in charge of data production should be noted; titles of the tables should be harmonized and revised; texts with analysis of the data published could be included; several acronyms should be spelled out or a list of acronyms should be included at the beginning of the publications; and stock data, such as domestic and external debt by sector, should be included. Detailed underlying data and time series are presented. The data disseminated on the MOF website present the coverage and detail set out in the GFSM 1986, and data are available for extensions in coverage and detail.

Recommendation: Improve the presentation of GFS on the website or in hard copy, as suggested above.

\subsubsection{Dissemination media and format are adequate}

The main statistical means of dissemination is the Statistical Bulletin, which includes explanatory notes, charts, and tables that facilitate analysis on current period developments and time series since 1990; and the UPF-IMF website with annual time series since 2000, and monthly and quarterly time series for the recent years.

Bolivia reports GFS data, for central government, general government, and its subsectors, to the IMF for publication in the GFS Yearbook. These data are compiled by the GDA.

\subsubsection{Statistics are released on a preannounced schedule}

GFS are disseminated according to a preannounced calendar shown on the IMF's DSBB and on the CBB website.

Recommendation: Post the preannounced calendar for dissemination of GFS on the MOF website. $^{13}$

\subsubsection{Statistics are made available to all users at the same time}

Fiscal data are made available to all users simultaneously.

13 The MOF has posted the pre-announced calendar for dissemination of GFS on the MOF website in March 2007. 


\subsubsection{Statistics not routinely disseminated are made available upon request}

Nonpublished, nonconfidential, disaggregated data are made available upon request. The availability of nonpublished data and the procedures for obtaining them are made known on the MOF website.

Upon request, the MOF provides methodological and statistical information, though there are no formal mechanisms to ensure close contact between GFS compilers and users. The MOF maintains routine communications with international agencies that use its statistics.

\subsection{Metadata accessibility}

5.2.1 Documentation on concepts, scope, classifications, basis of recording, data sources, and statistical techniques is available, and differences from internationally accepted standards, guidelines, or good practices are annotated

Only metadata for budgetary and accounting data are made public. For GFS, detailed metadata are posted only on the IMF's DSBB. These metadata give adequate information about the meaning of data and methodology used to collect and compile GFS. They include information about the concepts, data sources, definitions, classifications, compilation methods, and others. Bridge tables showing the links between source data and GFS are not prepared. Differences from internationally accepted standards are not identified. Metadata have not been updated since November 2005.

Recommendation: Post detailed GFS metadata and a link to the IMF's DSBB on the MOF website. $^{14}$

\subsubsection{Levels of detail are adapted to the needs of the intended audience}

GFS metadata on the IMF's $D S B B$ provide enough detail for the intended audience.

\subsection{Assistance to users}

\subsubsection{Contact points for each subject field are publicized}

A contact electronic address, website, telephone number, and address are provided on the MOF website and publications. The MOF provides support on technical matters to users requesting assistance.

\footnotetext{
${ }^{14}$ In March 2007, the MOF included a hyperlink to the IMF's DSBB on the MOF website.
} 
Material to raise awareness on the use of statistics is available, but assistance to users is not monitored.

5.3.2 Catalogs of publications, documents, and other services, including information on any charges, are widely available

The MOF website provides a list of available publications. The Statistical Bulletin is distributed free of charge. 
Table 4. Bolivia: Data Quality Assessment Framework (July 2003): Summary of Results for Government Finance Statistics (Compiling Agency: Ministry of Finance)

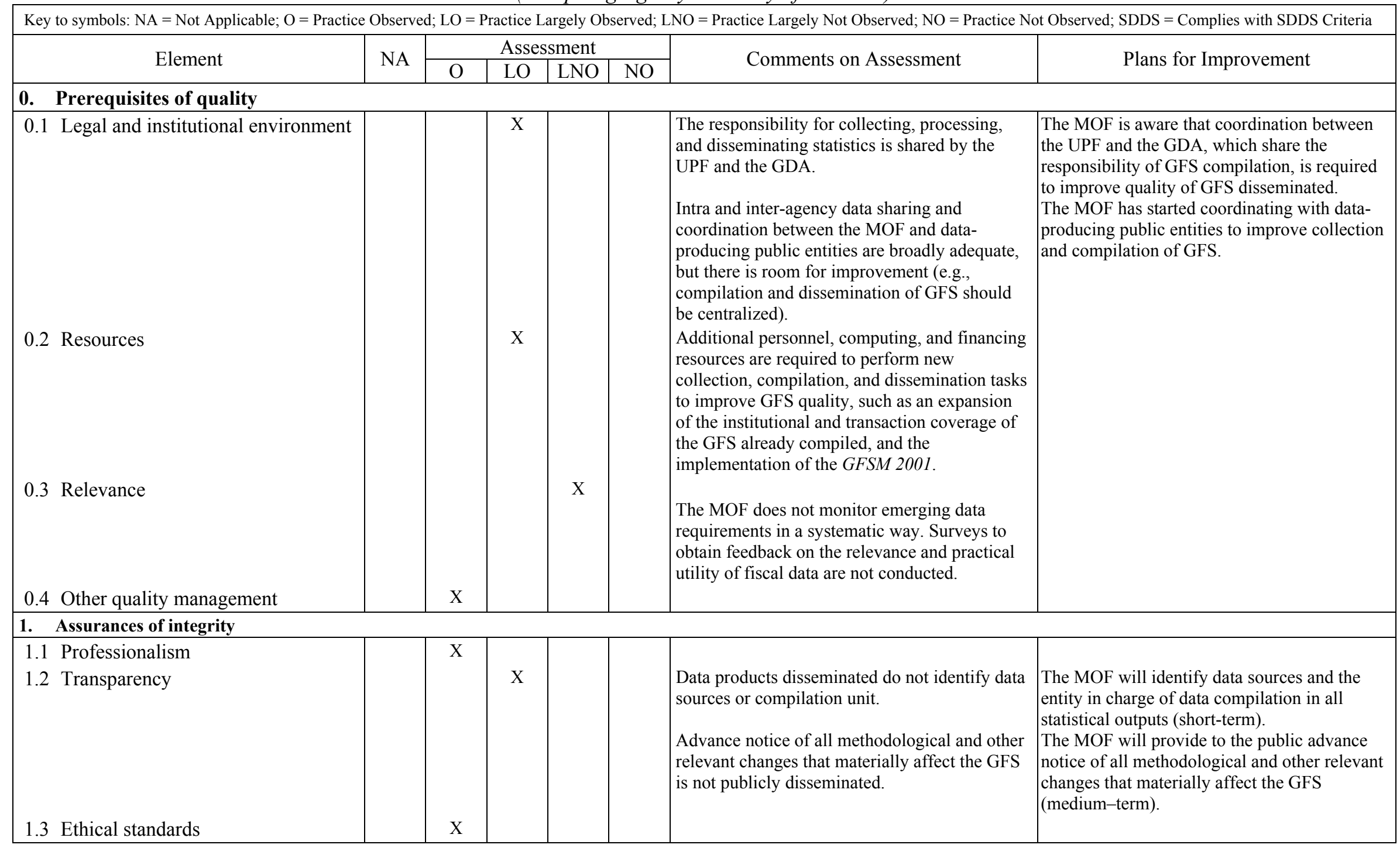


Table 4. Bolivia: Data Quality Assessment Framework (July 2003): Summary of Results for Government Finance Statistics (Compiling Agency: Ministry of Finance)

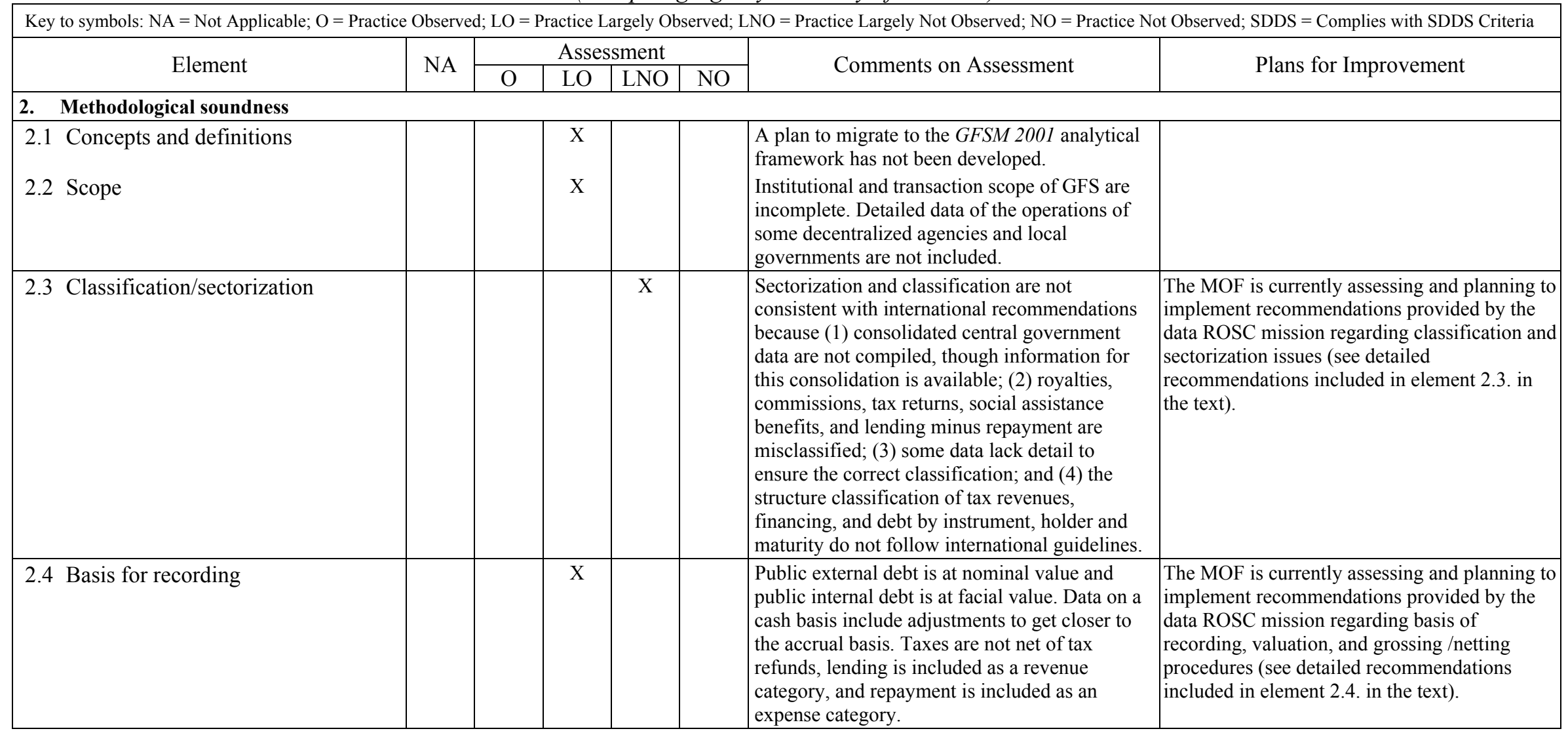


Table 4. Bolivia: Data Quality Assessment Framework (July 2003): Summary of Results for Government Finance Statistics (Compiling Agency: Ministry of Finance)

\begin{tabular}{|c|c|c|c|c|}
\hline \multicolumn{5}{|l|}{ 3. Accuracy and reliability } \\
\hline 3.1 Source data & & $\mathrm{X}$ & $\begin{array}{l}\text { Source data for GFS are: SIGMA, SICON, } \\
\text { UPF, DMFAS, and integrated systems of some } \\
\text { public units. Those non-integrated systems } \\
\text { increase, sometimes, collection efforts and } \\
\text { compilation burden. Also, they have an } \\
\text { incomplete institutional coverage. }\end{array}$ & \\
\hline 3.2 Assessment of source data & $\mathrm{X}$ & & & \\
\hline 3.3 Statistical techniques & $\mathrm{X}$ & & & \\
\hline $\begin{array}{l}\text { 3.4 Assessment and validation of inter- } \\
\text { mediate data and statistical outputs }\end{array}$ & $\mathrm{X}$ & & & \\
\hline 3.5 Revision studies & & $\mathrm{X}$ & $\begin{array}{l}\text { Revision studies and analyses are conducted, } \\
\text { but not documented. }\end{array}$ & \\
\hline \multicolumn{5}{|l|}{ 4. $\quad$ Serviceability } \\
\hline $\begin{array}{l}\text { 4.1 Periodicity and timeliness } \\
4.2 \text { Consistency }\end{array}$ & $\mathrm{X}$ & $\mathrm{X}$ & $\begin{array}{l}\text { GFS are consistent with BOP and monetary } \\
\text { statistics, but are not reconciled with the } \\
\text { national accounts. }\end{array}$ & \\
\hline 4.3 Revision policy and practice & & $\mathrm{X}$ & $\begin{array}{l}\text { Revision schedule is predetermined and } \\
\text { reasonably stable, but not publicized. Tables do } \\
\text { not include notes of revisions, and studies and } \\
\text { analysis of revisions are not made public. }\end{array}$ & \\
\hline \multicolumn{5}{|l|}{ 5. $\quad$ Accessibility } \\
\hline 5.1 Data accessibility & & $\mathrm{X}$ & $\begin{array}{l}\text { GFS permit identification and comparison of } \\
\text { major aggregates of flows and stocks, but there } \\
\text { is room for improvement. Advance release } \\
\text { calendar available on the CBB website and the } \\
\text { IMF's } D S B B \text {. }\end{array}$ & $\begin{array}{l}\text { The MOF will improve presentation of GFS on } \\
\text { the website and publications taking into } \\
\text { account recommendations provided by the data } \\
\text { ROSC mission (short-term). } \\
\text { The MOF has posted the preannounced } \\
\text { calendar for dissemination of GFS on the MOF } \\
\text { website in March } 2007 \text {. }\end{array}$ \\
\hline 5.2 Metadata accessibility & & $\mathrm{X}$ & $\begin{array}{l}\text { GFS metadata are disseminated on the IMF's } \\
\text { DSBB, but not on the MOF website. Metadata } \\
\text { needs to be updated more regularly. }\end{array}$ & $\begin{array}{l}\text { The MOF has included a hyperlink to the } \\
\text { IMF's DSBB on the MOF website in March } \\
2007 .\end{array}$ \\
\hline 5.3 Assistance to users & $\mathrm{X}$ & & & \\
\hline
\end{tabular}




\section{Monetary Statistics}

\section{Prerequisites of quality}

\section{$0.1 \quad$ Legal and institutional environment}

\subsubsection{The responsibility for collecting, processing, and disseminating the statistics is clearly specified}

In Bolivia, the responsibility for collecting, compiling, and disseminating monetary statistics is shared between the Central Bank of Bolivia (CBB) and the Superintendency of Banks and Financial Entities (SBFE). The Law of the Central Bank of Bolivia 1670/95 establishes in its article 40 that the "... Superintendency of Banks and Financial Entities will have the obligation to provide the $\mathrm{CBB}$ with all the periodic information it receives from banks and other entities of the financial system.... Banks and other entities of financial intermediation have the obligation to provide directly to the CBB the information of monetary nature the latter requests." Article 43 of such law establishes that, the "...CBB will periodically publish statistical and economic information on the economic and financial variables included in the area of its responsibilities."

The SBFE's responsibility for the supervision and control of the norms regulating the financial system is stated in article 34 of Law 1670/95. The faculty of the SBFE to request data from financial institutions under its supervision is established in article 93 of the Law of Banks and Financial Entities (1488/93), which states that the "... Superintendency shall request from each financial intermediation entity reports related to their situation and operations, as well as their balance sheets, indicating the content of such reports and the deadline for their submission."

The Functional Manual of the CBB endows the Economic Policy Advisory Office (APEC) with the responsibility to "supervise the compilation of monetary, financial, and fiscal statistics; their transmission to the Board, committees, and authorities of the CBB; and their dissemination to national entities, international organizations, and the general public." Within the APEC, the Monetary and Fiscal Sector Deputy Management Office (SSMF) is responsible for the compilation and dissemination of monetary statistics.

The SBFE and other governmental agencies also disseminate monetary statistics. The National Statistical Institute (NSI) reproduces in its Anuario Estadístico several monetary tables with data produced by the CBB, always quoting the source. Similar is the case for the annual Dossier de Estadisticas Económicas y Sociales de Bolivia of the Economic Policy Analysis Unit (UDAPE), with monetary tables based on CBB's data that include the source. The SBFE publishes its own financial data, based on the balance sheets and other information received from the financial institutions under its supervision. Most of the data published by the SBFE are identical with the data published by the CBB. However, data on transferable deposits published by the SBFE follow a slightly different approach than the data published by the CBB. This discrepancy may confuse users of monetary statistics. 


\subsubsection{Data sharing and coordination among data-producing agencies are adequate}

For the compilation of monetary statistics, the SSMF interacts within the CBB with the Accounting Deputy Management Office (SC), the Monetary Operations Management Office (GOM) and the Financial Entities Management Office (GEF), the latter being the contact point between the CBB and the SBFE.

The SSMF receives electronically from the SC the daily monetary balance of the CBB-a sectorized and adjusted trial balance used for monetary programming purposes - and has online access to the CBB's accounting records. The SSFM has also on-line access to the database of the GOM on auctions of central government and CBB's bonds and notes.

Other depository corporations (ODCs) transmit electronically to the SBFE their daily balance sheets plus other information, and at month-end their "sectoral accounts," which contain sectorized data for monetary statistics purposes. All this information is transmitted electronically from the SBFE to the GEF: with one-day lag in the case of daily data, and by the fifth day of the next month in case of monthly data. The GEF forwards the received data to the SSMF. Although this transmission should be almost immediate, there have been some delays in the forwarding of monthly data, a shortcoming that should be solved to further improve the timeliness of monetary statistics.

In addition to the formal institutional arrangements in place, the SSMF is in close contact with the SBFE, which has shown its readiness to attend requests from the CBB in matters related to monetary statistics, producing ad-hoc changes in the chart of accounts, asking for additional information from ODCs, and instructing individual ODCs to correct detected mistakes in their reporting.

\subsubsection{Individual reporters' data are to be kept confidential and used for statistical purposes only}

Article 80 of the Law 1670/95 guarantees the confidentiality of the information reported to the $\mathrm{CBB}$, stating that: "Directors, officials, and employees of the CBB have the obligation to keep the secrecy of the matters and operations of the $\mathrm{CBB}$, the financial institutions and their operations, as well as of the documents and reports related to them that come into their knowledge through the performing of their duties. Such obligations and responsibilities will extend even after they have finished their functions or left the CBB. The Director, official, or employee of the CBB that breach this prohibition will be fired and subject to the civil or penal responsibilities that correspond." Article 51 of the Staff Internal Regulation of the CBB foresees sanctions ranging from fine, suspension, and even discharge for breaching the data confidentiality. The Ethics Code of the CBB mentions in its Article 3 the confidentiality as one of its guiding principles and strictly forbids disclosing confidential information (Article 7). Furthermore, staff of the CBB must sign every year a confidentiality pledge with a detailed description of the information they can access and disseminate. 
In the case of the SBFE, the Law 1488/93 states the obligation to preserve the confidentiality of the data and operations of the financial system (article 88), even after staff of the SBFE leave their offices (article 89). Furthermore, the SBFE's Ethics Code refers in its article 17 to specific steps to protect the confidentiality of the received information.

Data are transmitted from the ODCs to the SBFE using dedicated encrypted lines, which together with firewalls ensures their safety against external attacks. Data are transmitted from the SBFE to the GEF also using an intranet encrypted line, which would collapse in case of an external intrusion. There is no external access to the data stored at the CBB, which are protected with firewalls and passwords against unauthorized access by internal users. In the case of monetary data, the GEF decides the level of access granted to the staff.

\subsubsection{Statistical reporting is ensured through legal mandate and/or measures to encourage response}

The SBFE issued several resolutions mandating ODCs to report electronically the following information. On a daily basis: balance sheet, regional distribution of deposits, liabilities to other financial corporations, capital/assets ratio, and interest rates. On a weekly basis: analysis of liquidity limits and projected cash-flow. On a monthly basis: balance sheet; financial statements; capital/assets ratio; deposits grouped by volume, maturity, and currency; sectoral accounts for monetary programming; loans by sector; foreign exchange position; and an additional report on nonperforming loans.

Article 99 of the Law 1488/93 foresees penalties to the financial institutions, their directors, trustees, managers, and employees that contravene the dispositions of the law, including noncompliance of the report requirements. In the case of financial reports, the noncompliance refers to timeliness as well as to accuracy of the reported data. At present, fines reach approximately US\$62.00 per day of noncompliance. In practice, ODCs report regularly to the SBFE within the prescribed time frame.

To encourage adequate response, the SSMF conducted a series of seminars throughout the country, attended by all ODCs. The seminars explained the participants the concepts and definitions of monetary statistics, sectorization and valuation criteria, the relevance of monetary statistics for policy making, and the importance of accurate reporting.

\section{$0.2 \quad$ Resources}

\subsubsection{Staff, facilities, computing resources, and financing are commensurate with statistical programs}

At end-January 2007, the SBFE had 159 professional, technical, and administrative staff, mainly in the areas of risk supervision (69). The area responsible for collecting data (Intendency of Studies and Norms) had a total of 16 persons, including the intendent and two division chiefs. They consider the number of staff, as well as the technical and financial resources, adequate for the work they are performing. Staff of the SBFE regularly attends 
training courses offered by international organizations, other supervisory agencies, other central banks, or private financial institutions. Historically, salaries at the SBFE have been higher than in the rest of the public sector and competitive with the private sector, resulting in a low staff turnover. However, the 2006 presidential decree reducing the salaries of the higher ranks of the public sector have resulted in a flattening of the salary scale, and the loss of several senior staff, who left for the private sector.

The SSMF - responsible, among others, for the compilation and dissemination of monetary and financial statistics - had at end-January 2007 a total of nine professional and two administrative staff, including the deputy manager and a division chief. Three professional staff of the SSMF, all with a university degree, are dedicated full-time to the compilation and dissemination of monetary and financial statistics plus related reports for monetary programming purposes. Taking into account that data collection and validation is carried out by the SBFE, this number seems adequate.

Salary levels at the CBB are broadly similar to the rest of the public sector, except for the SBFE, which pays higher salaries. The presidential decree reducing public salaries has also negatively affected the $\mathrm{CBB}$, resulting in a very flat salary scale where a manager earns only around US\$20.00 per month more than a deputy manager. The mission detected that some staff of the SSMF are ranked below their academic and professional level, something that may have a negative impact on staff morale.

Each staff has his/her own personal computer connected to the CBB's network, with the usual office software and access granted to the database according to their functions. However, Internet access is restricted to only two hours per day, which limits the working capabilities of the staff when they have to consult external sources. Similarly, the restriction of telephone use to three minutes per external call produces inefficiencies, specially taking into account the need to contact financial and government institutions to evacuate doubts and solve inconsistencies in the reported data.

\section{Recommendation: Revise the internal $C B B$ policy on access to the Internet and use of telephone for external calls.}

At the SBFE, the collected data are backed-up once a week, and once a month three copies are burned in magnetic supports, stored one at the computing center of the SBFE, one in an institutional repository within the SBFE, and one in vaults outside the SBFE. Additionally, the SBFE runs an alternative facility where it can conduct its operations in case of nonaccessibility to the headquarters.

Every day, all data processed by the CBB's central system is copied into three magnetic supports, one of which is stored in the vaults of a commercial bank. The CBB also runs a mirror on-line back-up outside headquarters, to prevent loss of information while processing it. Additionally, an external center is currently functioning as an alternative storage facility and will soon start operating as an alternative operational site in case of non-accessibility to the headquarters. Due to the low cost of storage, no data are destroyed. 
One weakness detected by the mission was the lack of automatic back-ups for data processed in personal computers. In fact, in September 2006, the hard disk of one of the staff working on monetary statistics crushed during the back-up of its files and the data could not be recovered. In view of this problem, the 2007 administrative budget foresees the acquisition of servers to centralize the information by floors and provide automatic back-up to data stored in individual desktops.

\subsubsection{Measures to ensure efficient use of resources are implemented}

The process of data transmission from the SBFE to the GEF, and from the GEF and other relevant departments of the $\mathrm{CBB}$ to the SSMF is fully automated, ensuring reliability and an efficient use of resources. Also the process of compiling central bank and ODC surveys are fully automated at the SSMF.

Staff performance at the CBB's is evaluated twice a year. Although this appraisal does not impact salary levels, it is used when evaluating internal candidates for an open position, but carrying a relative low weight. The CBB does not have a policy of periodically evaluating the resources dedicated to the statistical processes to prioritize activities. In case of shortage of resources, activities with lower cost have generally taken precedence, irrespective of their relevance.

\subsection{Relevance}

\subsubsection{The relevance and practical utility of existing statistics in meeting users' needs are monitored}

Although the CBB does not have a policy of periodically consulting users of monetary statistic about their needs, it has continually shown its commitment to improve their relevance. Beyond the technical assistance requested from the IMF, the SSMF takes into account suggestions provided by users through its website and participates in international meetings.

Data collected by the SBFE are mainly for supervisory rather than for statistical purposes, making the SBFE the main user of the data it collects. As provider of source data to the $\mathrm{CBB}$, the SBFE has consistently adapted its requirements from ODCs to meet CBB's emerging needs on monetary statistics. Additionally, the SBFE publishes financial data on its website and provides users with analytical tools to process this information. Staff of the SBFE regularly attends technical meetings on banking supervision. 


\subsection{Other quality management}

\subsubsection{Processes are in place to focus on quality}

Staff of the SSMF is fully aware of the importance of quality in building trust among monetary statistics users, and they are sensitive to the different dimensions of data quality. Processes are in place to check the quality of the published data, and monetary statistics normally do not present a trade-off between timeliness and accuracy. However, in the few cases where such trade-off existed, the SSMF gave priority to data accuracy.

In accordance with its mission statement and its institutional vision, the SBFE developed a five-year strategic plan. For the period 2002-2007 the defined strategic objectives comprise actions to measure and monitor systemic risks, to provide the financial system with a prudential framework that promotes transparency, and to foster efficiency.

\subsubsection{Processes are in place to monitor the quality of the statistical program}

The CBB does not have an established process for systematically monitoring the quality of the statistical program. For external advice on monetary statistics, the CBB relies almost exclusively on the technical assistance provided by the IMF.

\subsubsection{Processes are in place to deal with quality considerations in planning the statistical program}

The annual operational program of the $\mathrm{CBB}$ outlines developmental and functional objectives. Very often, these objectives are related with the quality of monetary statistics, like the expansion of the coverage, the inclusion of nonbank financial institutions into the monetary program, etc. Quality improvement needs are normally identified when staff of the SSMF attend training courses or when the SSMF receives technical assistance.

\section{Assurances of integrity}

\subsection{Professionalism}

\subsubsection{Statistics are produced on an impartial basis}

The CBB and the SBFE are independent, autarkic institutions. Technical criteria alone are applied by data compilers and analysts of the CBB and the SBFE, and they are totally independent in their choice of data collection methods. Staff of both institutions are hired on a permanent basis following a competitive process. Internal promotions follow also a competitive process that takes into account the professional capabilities of the candidates and their past performance. These contractual conditions protect them against undue pressures or interference by other government agencies, ensuring their professional independence. 
Training relies on the participation in international courses and seminars from the IMF and other international organizations. Out of the nine professional staff of the SSMF, seven have attended the IMF's Monetary and Financial Statistics Course, all nine the Financial Programming Course, and one the seminar on the MFSM Compilation Guide. Additionally, they have attended several courses offered by the Center for Latin American Monetary Studies (CEMLA). Internal discussions on monetary statistics take place within the APEC. One deputy management office of the APEC is fully dedicated to research work and its staff has published articles in CBB's magazines and other specialized journals.

\subsubsection{Choices of sources and statistical techniques as well as decisions about dissemination are informed solely by statistical considerations}

The source data for monetary statistics are the balance sheets of the CBB, 12 commercial banks, six banks in liquidation, 24 credit unions, nine savings and loans associations, and six private investment funds. Full coverage of all units in each subsector restricts the possibilities of manipulation through changes in the sample. Other financial statistics not based on accounting records, such as interest rates, are produced using responses by all institutions of the system. For the classification of financial instruments and sectorization of the accounts, the SSMF follows the methodology of the Monetary and Financial Statistics Manual $(M F S M)$.

The dissemination of monetary data follows an established procedure with deadlines announced in an advance release calendar. The periodicity and timing of data dissemination were never hampered by pressures from other government agencies.

\subsubsection{The appropriate statistical entity is entitled to comment on erroneous interpretation and misuse of statistics}

In cases of misinterpretation or misuse of published monetary data, the CBB provides comments and clarifications mainly through its Institutional Communications Department. To avoid misinterpretations of monetary data, the CBB also makes available press releases and technical reports. In the recent past there were no cases of misinterpretation of monetary data. The Institutional Communications Department reviews daily the information disseminated by the media and produces the necessary clarifications, when needed.

\subsection{Transparency}

\subsubsection{The terms and conditions under which statistics are collected, processed, and disseminated are available to the public}

Bolivia is a participant in the IMF's General Data Dissemination System (GDDS). Its metadata on monetary statistics are accessible on the IMF's Dissemination Standards Bulletin Board (DSBB) and were last updated in December 2005. Additionally, the CBB website contains a window Metadatos, with monetary statistics metadata in Spanish and a link to the IMF's DSBB. Laws 1670/95 and 1488/93 are quite explicit regarding the legal 
terms and conditions for collecting monetary information, and are posted on the $\mathrm{CBB}$ and the SBFE websites.

The brochure Definiciones de Términos Empleados en la Información Estadística Semanal is available on the CBB website, within the window Educative Publications. This brochure contains the description of the main indicators produced in monetary statistics, and hardcopies of it are distributed to schools and fairs. In every seminar organized to explain the relevance of monetary statistics, the CBB describes the terms and conditions under which such statistics are compiled.

The SBFE website contains the legal regulations governing its activities, as well as a detailed description of the work and responsibilities of its different departments.

\subsubsection{Internal governmental access to statistics prior to their release is publicly identified}

The latest monetary data, together with other macroeconomic data, are provided regularly to the Macroeconomic Group, an economic policy analysis committee. ${ }^{15}$ Depending on the scheduled release calendar, the Macroeconomic Group may or may not have access to the statistics prior to its public dissemination. However, this earlier access does not interfere with the scheduled release of the data. On its website, the CBB acknowledges this possibility of selected access prior to release.

\subsubsection{Products of statistical agencies/units are clearly identified as such}

All publications of the CBB and the SBFE are clearly identified as a product of these institutions, with their logos and addresses. All tables of the CBB's publications contain the source of the data and the unit responsible for their compilation. Data of the CBB may be reproduced but quoting the source, and the $\mathrm{CBB}$ systematically controls that this requirement is fulfilled.

\subsubsection{Advance notice is given of major changes in methodology, source data, and statistical techniques}

Advance notice is not given to the public when there are major changes in methodology. However, when the SSMF revises monetary data as a result of the implementation of IMF missions' recommendations or other methodological changes, detailed notes are included to explain the breaks in the series and their effect on the monetary variables.

\footnotetext{
${ }^{15}$ Currently, the Macroeconomic Group comprises the Minister of Finance, the CBB President, the Minister of Planning, the Deputy Ministers of Budget, Treasury, Tax Policy, Public Investment, and Pensions, and the Executive Directors of NSI, UDAPE, Fiscal Policy Unit (UPF), and the Fiscal Analysis Network (RAF).
} 
The SSMF is currently in the process of expanding the coverage of the ODCs survey through the inclusion of the Investment Funds Management Societies (SAFIs); and compiling an other financial corporations (OFCs) survey with data from insurance corporations, pension funds, and other financial intermediaries. This could be a good opportunity to inform the public in advance about the upcoming methodological changes.

Recommendation: Give advance notice to the users of the upcoming expansion of the coverage of the ODC survey, the compilation of an OFC survey, and any other major methodological revision.

\subsection{Ethical standards}

\subsubsection{Guidelines for staff behavior are in place and are well known to the staff}

The Law on Public Servants (2027/99) provides the general umbrella to regulate the legal situation of permanent and contractual public employees, including staff of the CBB. The law states rights, obligations, and incompatibilities of persons working for the public sector.

At the level of the CBB, its Internal Staff Regulation from 2001 contains ethical rules for staff behavior, including rights and obligations (arts. 4-6), incompatibilities and conflict of interest (arts. 7-10), and sanctions in cases of misconduct (arts. 48-52). The regulation forbids CBB staff to work anywhere else in the public sector except as university professor, to enter in private contracts or transactions related with their functions at the CBB, or breach the confidentiality of the information acquired in their functions, among others. The Code of Conduct of the CBB, distributed to its entire staff, reflects the Internal Staff Regulation and deals with issues of integrity, professional independence, fidelity, independence, confidentiality, mutual respect, transparency, etc. The Code of Conduct foresees the creation of an ethics committee with three full members and three alternate members appointed each pair by the President of the $\mathrm{CBB}$, the General Manager, and the CBB staff.

The Ethics Code of the SBFE deals with issues of truthfulness, justice, mutual respect, responsibility, transparency, and integrity. The Code establishes an ethic committee as an organ in charge of promoting, implementing and updating the Ethics Code. The ethic committee is constituted by three full and two alternate members; being one full member designated by the Superintendent and the other four through a ballot process by the staff of the SBFE. The Ethics Code is of obligatory knowledge for all staff working at the SBFE. 


\section{Methodological soundness}

\subsection{Concepts and definitions}

\subsubsection{The overall structure in terms of concepts and definitions follows internationally} accepted standards, guidelines, or good practices

The methodological framework used by the SSMF to compile the central bank survey and the ODC survey is consistent with the guidelines of the MFSM. Some discrepancies from these guidelines were resolved when the SSMF implemented the recommendations of the 2006 IMF monetary and financial statistics mission.

A depository corporations survey (DCS) is compiled consolidating the central bank survey with the ODC survey. The main monetary and credit aggregates identified within this framework are:

- Base money: notes and coins in circulation and deposits of ODCs with the CBB.

- M1: notes and coins in circulation outside the banking system and current account and sight deposits in national currency of the private sector with ODCs.

- M1': M1 and current account and sight deposits in foreign currency and national currency with value maintenance of the private sector with ODCs.

- M2: M1 and savings deposits in national currency of the private sector with ODCs.

- M2': M1' and savings deposits in national currency, foreign currency, and national currency with value maintenance of the private sector with ODCs.

- M3: M2 and time deposits and other deposits in national currency of the private sector with ODCs.

- M3': M2' and time deposits and other deposits in national currency, foreign currency, and national currency with value maintenance of the private sector with ODCs.

- M4: M3 and treasury bills in national currency held by the nonfinancial private sector.

- M4': M3' and treasury bills in national currency, foreign currency, and national currency with value maintenance held by the nonfinancial private sector.

- CBB's net international reserves, CBB's net credit to the public sector, CBB's credit to the banking sector.

- Net foreign assets of the ODCs, ODC's net credit to the public sector, ODCs' credit to the private sector.

\section{$2.2 \quad$ Scope}

2.2.1 The scope is broadly consistent with internationally accepted standards, guidelines, or good practices

At end-January 2007, Bolivia's depository corporations sector comprised the CBB, 12 commercial banks, 24 credit unions, nine savings and loans associations, six private investment funds, six banks in liquidation, and 7 SAFIs. The SAFIs are the only entities of the ODC sector that are not under the supervision of the SBFE, but are regulated by the 
Superintendency of Pensions, Securities, and Insurances (SPSI). The SAFIs belong to commercial banks and manage portfolio investments of the private sector, issuing to their investors a debit card that can be used to withdraw funds from their investments, making them a close substitute of money. SAFIs liabilities to their investors account for around six percent of broad money.

The central bank survey is prepared on the basis of the CBB's "monetary balance," which is a reclassified and adjusted trial balance transmitted daily from the SC to the SSMF.

All entities regulated by the SBFE are included in the ODC survey, with data covering the headquarters and all domestic branches. Banks in liquidation are also included in the ODC survey, but not the SAFIs because the financial system in Bolivia regards as ODCs only the financial entities supervised by the SBFE.

Recommendation: Expand the coverage of the ODC survey, to include the accounts of the SAFIs.

Going beyond the scope of monetary statistics, Bolivia is in a position to compile a monthly other financial corporations (OFC) survey, with data from the two pension funds and the eight insurance corporations operating in the country and regulated by the SPSI, as well as the accounts of the two state-owned financial corporations, namely NAFIBO and FONDESIF. The SSMF has already contacted the SPSI to receive monthly data of pension funds and insurance corporations, and is undertaking efforts towards the compilation of an OFC survey, which is a cornerstone for the production of flow of funds accounts and a balance sheet approach matrix. The SPSI can transmit electronically to the SSMF aggregated monthly data on insurance corporations suitable for processing. However, it can only transmit individual monthly data of the two pension funds, which would require to develop a routine to aggregate them.

Recommendation: Start compiling a monthly OFC survey, with data from pensions funds, insurance corporations, and the three state-owned financial corporations. To automate the process, the Systems Management Office should develop a computing routine to aggregate the data of the two pension funds.

\subsection{Classification/sectorization}

\subsubsection{Classification/sectorization systems used are broadly consistent with internationally accepted standards, guidelines, or good practices}

Except for the problems listed below, sectorization of monetary statistics follows the recommendations of the MFSM, including the classification of repurchase agreements as loans, prepaid insurances as insurance technical reserves, and forwards and future contracts as financial derivatives. At end-2006, the CBB migrated to the new standardized report forms for the central bank and ODCs, eliminating almost all problems of classification and sectorization of financial instruments. 
The chart of accounts for ODCs follows international accounting standards, but reflects pure prudential standards and does not allow an adequate sectorization. This information is provided once a month in the additional report "sectoral accounts," which groups the main accounts of the balance sheet by economic sector and institutional unit. Since July 2002, these "sectoral accounts" are reported regularly to the SBFE and transmitted to the SSMF, which uses them to prepare an ODC sectoral balance sheet according to the methodology of the MFSM.

Financial instruments are classified by type, maturity, and currency denomination (local, local with maintenance of value, U.S. dollars, and indexed to the U.S. dollar). Although the "sectoral accounts" provide categories for residents and nonresidents - in line with the principles of the Balance of Payments Manual, $5^{\text {th }}$ edition (BPM5) - some ODCs report accounts of nonresidents (e.g., embassies) as accounts of residents. The SSMF has identified many of these cases of misclassification and contacted the SBFE to instruct such ODCs to properly report them. Similarly, the SSMF has also identified cases of incorrect sectorization of accounts of public nonfinancial corporations, or of the private nonfinancial sector.

Until December 2006, ODCs reported accounts of SAFIs as accounts of OFCs, simply because in the "sectoral accounts" there was not a category for this type of financial entities. Similarly, all accounts of private nonfinancial resident units were reported as Other resident accounts, not distinguishing between Other nonfinancial corporations (private enterprises) and Other resident sectors (households and NPISHs), again simply because the "sectoral accounts" provided only for one category. This last shortcoming does not affect the calculation of net domestic credit, but will constitute a problem when the country produces financial accounts. In November 2006, the SBFE instructed the ODCs that, starting with their report for the month of January 2007, accounts of SAFIs should be identified in a new category different from other OFCs, and that accounts of private nonfinancial residents should be separated into private enterprises and other resident sectors.

Recommendation: In collaboration with the SBFE, undertake efforts to eliminate the detected mistakes in the sectorization of the accounts of ODCs.

\subsection{Basis for recording}

\subsubsection{Market prices are used to value flows and stocks}

The instructions of the SBFE indicate that financial assets and liabilities denominated in foreign currency, in local currency but adjusted to the U.S. dollar, and in local currency indexed by the CPI, should be adjusted at least at the end of the month using the buyer market exchange rate informed by the $\mathrm{CBB}$ and the UFB, ${ }^{16}$ respectively. In practice, ODCs adjust daily the balances of these accounts. The CBB also adjusts daily its assets and

${ }^{16}$ UFV = Unidad de Fomento de la Vivienda (Housing Promotion Unit) is a daily index based on the CPI. 
liabilities denominated in foreign currency or indexed to the US dollar or the UFV; this includes gold holdings (valued at market prices), SDR holdings, and its reserve position in the IMF.

ODCs supervised by the SBFE shall value their holdings of securities at the lower of the amortized cost (acquisition cost plus accrued interest) or market price. The CBB values its holdings of securities at amortized cost.

\subsubsection{Recording is done on an accrual basis}

The CBB records its accounts on an accrual basis and registers the accrued interest together with its underlying instrument. In their daily balance sheet, ODCs record their accounts also on an accrual basis, but present all accrued interest in Accrued products on the liability and asset sides. However, the monthly "sectorized accounts," used for the compilation of monetary statistics, disaggregate the accrued interest and allow its classification together with its underlying instrument. According to instructions of the SBFE, interest cannot be accrued on loans overdue for more than 91 days, or loans to debtors with nonperforming loans in other institutions of the system.

\subsubsection{Grossing/netting procedures are broadly consistent with internationally accepted standards, guidelines, or good practices}

Assets and liabilities of the CBB and ODCs are presented on a gross basis, with no netting of claims of a particular transactor against the liabilities to that transactor or group of transactors. Accounts in overdraft are recorded and reported as loans to the corresponding sector. Loans are recorded on a gross basis, with provisions for loan losses reported as a negative asset subtracting from the total loans, as required by international accounting standards. When compiling the surveys, the SSMF reclassifies these provisions to the liability side of the balance sheet, as Other accounts payable, following the recommendations of the MFSM.

In accordance with the guidelines of the MFSM, the accounts of the commercial banks, credit unions, savings and loans associations, and investment funds are consolidated in Other items net for the compilation of the ODC survey. In the DCS, the accounts of the CBB are consolidated with the accounts of the ODCs, also in Other items net.

\section{Accuracy and reliability}

\subsection{Source data}

\subsubsection{Source data are obtained from comprehensive data collection programs that take into account country-specific conditions}

The use of a common chart of accounts greatly simplifies the compilation of monetary statistics. The accompanying manual of accounts contains detailed instructions on the use 
and recording of each account. The chart of accounts for ODCs is based on a ten-digit code, but it is geared towards prudential goals and do not contain a code to sectorize the accounts.

Due to the nonviability of adding an extra code for sectorization in the chart of accounts, in July 2002 the SBFE requested from the ODCs a monthly "sectorized accounts" report. These "sectorized accounts" group the public sector accounts into Treasury, central government except Treasury, social security, public decentralized entities, departments, municipalities, and public nonfinancial corporations. The financial sector is divided into central bank, commercial banks, savings and loans associations, credit unions, private investment funds, insurance corporations, pension funds, stock exchange, financial service corporations, and second-tier financial corporations. The private nonfinancial sector is classified in only one category, without separating between enterprises, households, and NPISHs. Accounts of nonresidents are classified into embassies and other official representations, foreign corporations, overseas financial corporations, overseas headquarters and branches, and other nonresidents.

\subsubsection{Source data reasonably approximate the definitions, scope, classifications, valuation, and time of recording required}

The DCS is based on actual accounting records of the CBB and the ODCs. Therefore, no sampling or estimations are employed by the SSMF. The structure of the "sectorized accounts" permits an adequate sectorization and identification of the accounts of residents and nonresidents (as long as the ODCs report them correctly), and a proper sectorization of the resident accounts (except for the lack of distinction within other resident sectors and the misclassification of SAFIs mentioned in item 2.3.1). ODCs follow international accounting standards when recording their transactions. The monetary balance sheet of the CBB is audited quarterly by the Internal Audit Management Office. The CBB's financial statements are audited by an external accounting firm selected through a competitive process, which rotates every year. The 2005 annual balance sheet was audited by a local firm correspondent of an international accounting firm, and was approved with an unqualified opinion.

\subsubsection{Source data are timely}

The SC prepares the CBB's monetary balance sheet on a daily basis, and transmits it electronically to the SSMF, which has also on-line access to the accounting records. ODCs transmit electronically their daily balance sheets (plus other information) to the SBFE, before 2:00 p.m. of the following day. Each month they report their monthly balance sheets, plus the sectorized accounts, two working days after the end of the reference month. The SBFE transmits to the GEF the daily data the next day and the monthly data within five days after the end of the reference month. This automated process allows the SSMF to produce timely monetary data, although the communication between the GEF and the SSMF can be even improved, because sometimes the monthly data were not immediately forwarded from the former to the latter. 


\subsection{Assessment of source data}

3.2.1 Source data-including censuses, sample surveys and administrative records-are routinely assessed, e.g., for coverage, sample error, response error, and nonsampling error; the results of the assessments are monitored and made available to guide statistical processes

After receiving the electronic submissions of the ODCs, the SBFE performs automatic validation and consistency checks, which range from the simple comparison of assets and liabilities to detection of balances with the wrong sign in selected accounts, unusual movements in their balances, and cross-checking of the interbank position in what the SBFE calls a contagion matrix. If the submitted data fail any of this consistency checks, they are returned to the reporting institutions for their revision.

In addition to these validations, the SSMF reviews visually the data at an individual institution level and compares them with other internal and external sources, like the data on auctions of Treasury and CBB's securities. It also verifies the accuracy of the position reported by ODCs vis-à-vis the CBB. These controls allow the SSMF to detect unusual movements in the balances of the accounts and mistakes in their sectorization. What the SSMF lacks is a computing routine that automatically flags substantial movements or unexpected balances in selected accounts, avoiding in this way the visual checks.

Recommendation: Develop a routine that automatically flags significant changes in the balances of selected accounts, or balances that do not correspond with the expected values.

Due to the bank secrecy, the SSMF does not have access to supplementary information that would allow the verification of the sectorization of the reported data, such as a list of the largest depositors or a list of the largest debtors by institution. The SBFE receives information of this kind, but only identifying the accounts number but not the holders of these accounts. Staff of the SSMF is comfortable with the quality of the data reported by ODCs, although it acknowledges that improvements are needed in the sectorization by some institutions.

\subsection{Statistical techniques}

\subsubsection{Data compilation employs sound statistical techniques to deal with data sources}

Because the balance sheets of the individual ODCs, their "sectoral accounts," and the CBB's balance sheet are processed electronically, the risk of mistakes is minimal. Data reported by ODCs are complete and the SSMF does not estimate missing information. In cases of missing data by some institution, the SSMF postpones the publication of the monetary survey and wait for the missing data. 


\subsubsection{Other statistical procedures (e.g., data adjustments and transformations, and statistical analysis) employ sound statistical techniques}

For the estimation of the data of the six banks in liquidation, the SSMF proceeds as follows. For three institutions, it receives monthly updates of their balance sheets. For the remaining three, the SSMF estimates the balances of the foreign currency, U.S. dollar adjusted, and CPI-indexed accounts on the basis of the market exchange rate and the UFV, respectively. Additionally, when the SSMF is notified of movements in some accounts (e.g., a loan recovery), it correspondingly adjusts the balance sheet. This is the only case when estimation is needed for the compilation of monetary statistics.

\subsection{Assessment and validation of intermediate data and statistical outputs}

\subsubsection{Intermediate results are validated against other information where applicable}

Data reported by ODCs on their position vis-à-vis the CBB are verified with CBB's accounting records. Interbank positions are automatically validated by the SBFE in its contagion matrix.

Data reported by ODCs on securities are cross-checked against data available at the GOM on auctions of Treasury and CBB's securities. The SSMF also contacts the MOF to receive information on the securities sold directly to the public. The SSMF is unable to follow the securities beyond the first buyer. If a bank buys securities on behalf of a client, it appears as a holder of the securities in the GOM records, although it would not report them on its balance sheet. An ongoing project will allow the SSMF to have automatic access to information of the Securities Enterprise and precisely know the final holder of the securities.

The SSMF cross-checks the below-the-line financing of the general government with accounting records of the CBB and data on credit and deposits of ODCs. For this exercise, it is in permanent contact with the Fiscal Programming Unit (UPF) of the Ministry of Finance. The CBB's monetary balance sheet contains ad-hoc adjustment to government accounts to reflect transactions not yet booked in the trial balance.

\subsubsection{Statistical discrepancies in intermediate data are assessed and investigated}

Monetary statistics are validated using the identities:

Monetary Base $=$ Net International Reserves + Net Credit to Government + Credit to the Economy + Other Items Net (includes non reserve net foreign assets), and

Broad Money $=$ Net Foreign Assets + Net Credit to Government + Credit to the Economy + Other Items Net.

ODCs stock data at month-end are validated with flow data calculated from the daily balance sheets of ODCs. The quarterly intersectoral matrix compiled by the SSMF, which comprises ten economic sectors, is another tool used to verify the accuracy of monetary data. 
Beyond the automatic controls performed by the SBFE, the SSMF checks the daily data reported by the banks to detect mistakes, large movements, and inconsistencies. As already said, these controls are mostly visual.

\subsubsection{Statistical discrepancies and other potential indicators of problems in statistical outputs are investigated}

When discrepancies are detected in ODCs reported data, the SSMF contacts directly the reporting institution to inquire about the problem. This is, for instance, the case when data reported on government securities differ from the records on securities auctions at the GOM. Similarly, significant changes in the accounts balances or suspicion of misclassifications are also investigated. The SSMF prefers to solve the problem through direct contacts with the reporting institutions, to spare them a fine from the SBFE. If the error persists, the SSMF informs the SBFE about the problem.

\subsection{Revision studies}

\subsubsection{Studies and analyses of revisions are carried out routinely and used internally to inform statistical processes (see also 4.3.3)}

The main source of revisions of monetary data was the technical assistance provided by the IMF through its monetary and financial statistics missions in 1999, 2001, and 2006. The SSMF showed its commitment to improve the monetary statistics by implementing most of the missions' recommendations and migrating to the new standardized report forms at end2006. Data were revised from December 2001 onwards for the CBB and from July 2002 onwards for ODCs, and the revisions in the time series and their impact on the monetary aggregates was explained in the notes that accompany the tables of Boletin Mensual.

The SSMF keeps a file where it documents the most common detected mistakes, the actions taken for their solution, and the effects of the revisions on monetary and financial data.

\section{Serviceability}

\subsection{Periodicity and timeliness}

\subsubsection{Periodicity follows dissemination standards}

Daily data on central bank's aggregates are published on the CBB website once a week. Daily financial data of ODCs are also published once a week on the CBB website. Monetary data are published with a monthly frequency on the $\mathrm{CBB}$ website and the $\mathrm{CBB}$ Boletin Mensual. Interest rates are also compiled with a daily frequency and disseminated once a week. This periodicity not only follows GDDS recommendations but also meets SDDS requirements. 


\subsubsection{Timeliness follows dissemination standards}

Central bank's aggregates are disseminated the Tuesday after the end of the reference week, while complete monetary statistics are disseminated within three weeks after the end of the reference month on the CBB website. This timeliness fully follows GDDS recommendations and meet SDDS requirements. Monetary data are later published in the CBB Boletin Mensual, the quarterly Boletín Estadístico, and the Memoria Anual.

\subsection{Consistency}

\subsubsection{Statistics are consistent within the dataset}

The SSMF performs consistency checks to ensure that monetary statistics are internally consistent. This includes the positions of the CBB vis-à-vis the individual institutions, and the aggregated interbank positions. The incorporation of the SAFIs in the ODC survey may generate an internal inconsistency because the SAFIs deal mostly with deposit certificates, which they report as claims on banks, while the banks report them as liabilities to the nonfinancial private sector (time deposits). To solve this problem, once the SAFIs are incorporated into the ODC survey, the SSMF should adjust downwards the data reported by commercial banks as time deposits for the amount reported by SAFIs as claims on banks, and reclassify this figure as liabilities to SAFIs (i.e., to ODCs).

\subsubsection{Statistics are consistent or reconcilable over a reasonable period of time}

Time series are consistent for the past ten years, when the coverage of the ODC survey was expanded to include the credit unions, private investment funds, and savings and loans associations. Occasional revisions in the time series due to methodological changes are highlighted in the tables and explained in footnotes, including their effect on monetary aggregates.

\subsubsection{Statistics are consistent or reconcilable with those obtained through other data sources and/or statistical frameworks}

Monetary data are consistent with balance of payments data because the External Sector Deputy Management Office of the APEC (SSE) takes the figures produced by the SSMF. Discrepancies in published monetary and balance of payments series are fully explained by the different approach used in both datasets. Monetary stock data are valued at the closing date prices and converted into national currency using market exchange rates. Balance of payments flows are on a transactions basis, excluding gold price changes and exchange rate variations between the U.S. dollar and the SDR.

Monetary data on credit to the nonfinancial public sector are consistent with fiscal data at an aggregated level, after the adjustments performed by the UPF to convert the cash basis data into an accrual basis. Discrepancies between data published by the CBB and the MOF originate in the use of a fixed programming exchange rate for MOF's data, and daily market 
exchange rates for monetary data. Inconsistencies may appear at lower levels of government finance data (e.g., net credit to public enterprises), due to internal credits (or debits) in fiscal accounts that are not reflected in monetary statistics. The mission carried out a consistency check exercise between both datasets and verified their coherence.

\subsection{Revision policy and practice}

\subsubsection{Revisions follow a regular and transparent schedule}

Monetary data posted on the CBB website and published in Boletin Mensual are generally of a final nature and only exceptionally subject to revision. Therefore, the CBB does not have a predetermined revision cycle.

\subsubsection{Preliminary and/or revised data are clearly identified}

Through the corresponding notes, the public is made aware of preliminary and revised data.

\subsubsection{Studies and analyses of revisions are made public (see also 3.5.1)}

Studies and analyses of revisions are not made public, but explanatory notes are added to the tables when data were revised.

\section{Accessibility}

\subsection{Data accessibility}

5.1.1 Statistics are presented in a way that facilitates proper interpretation and meaningful comparisons (layout and clarity of text, tables, and charts)

Monetary statistics are first disseminated on the CBB website and later published in Boletin Mensual, Boletin Estadistico, and Memoria Anual, which are also posted on the CBB website. The tables present the information in a clear form and with an adequate level of detail. Notes accompany all the tables, including explanations of changes due to revisions. The Memoria Anual contains a section analyzing macroeconomic trends. The semi-annual Informe de Politica Económica contains an analysis of the macroeconomic situation, including the monetary sector, supported by tables and graphs. In this Informe, monetary series are seasonally adjusted using ARIMA 12.

\subsubsection{Dissemination media and format are adequate}

Boletín Mensual, Boletín Estadístico, Informe de Política Económica, and Memoria Anual are available through the $\mathrm{CBB}$ website and in hardcopies. Time series posted on the website are accessible in an Excel format. The latest available series at the time of the mission's visit to La Paz correspond to December 2006. 


\subsubsection{Statistics are released on a preannounced schedule}

The CBB posts a release calendar on its website, but in some occasions the deadlines were not met.

\subsubsection{Statistics are made available to all users at the same time}

Monetary statistics are first released on the CBB website, but the public may not be aware of the weekly statistics posted on the website. The press is not informed in advance of the data to be released.

Monetary data may be made available to the Macroeconomic Group prior to their public dissemination, but this early access does not interfere with the scheduled release calendar. This practice is acknowledged both on the $\mathrm{CBB}$ website and at the $\mathrm{CBB}$ metadata posted on the IMF's DSBB.

\subsubsection{Statistics not routinely disseminated are made available upon request}

The accessibility of monetary data in an Excel format through the CBB website has significantly reduced individual requests to the SSMF. Upon request, and with the authorization of the President of the CBB or the Director of the APEC, the SSMF provides nonpublished but nonconfidential information. The $\mathrm{CBB}$ does not indicate that additional information can be obtained, but the public is aware that they can contact the unit that appears in the tables as responsible for their elaboration.

\subsection{Metadata accessibility}

5.2.1 Documentation on concepts, scope, classifications, basis of recording, data sources, and statistical techniques is available, and differences from internationally accepted standards, guidelines, or good practices are annotated

Metadata on monetary statistics are available on a specific window (Metadatos) on the CBB website, which contains a link to the IMF's DSBB. The latest update of the metadata on the DSBB took place in December 2005, and is now in a revision process with a view to subscribing to the SDDS.

In addition to the metadata, the CBB publishes a series of brochures on its functions, responsibilities, and monetary statistics. The most relevant one regarding concepts and methodology is Definiciones de Términos Empleados en la Información Estadística, which contains the definitions of monetary base, monetary aggregates, net international reserves, net credit to the public sector, etc. The brochures are posted on the CBB website and also widely distributed to schools and in fairs. 


\subsubsection{Levels of detail are adapted to the needs of the intended audience}

The level of disaggregation contained in the CBB's publications is sufficient to meet different audiences' needs.

\subsection{Assistance to users}

\subsubsection{Contact points for each subject field are publicized}

The CBB website provides names and electronic mail of the persons that can be contacted in relation with monetary and other statistics, indicating their area of responsibility.

5.3.2 Catalogs of publications, documents, and other services, including information on any charges, are widely available

A catalog with the publications of the $\mathrm{CBB}$ and their prices is available and also posted on the CBB website. The catalog posted on the website contains a form to be filled electronically and submitted by e-mail. 
Table 5. Bolivia: Data Quality Assessment Framework (July 2003): Summary of Results for Monetary Statistics (Compiling Agency: Central Bank of Bolivia)

\begin{tabular}{|c|c|c|c|c|c|c|c|}
\hline \multirow{2}{*}{ Element } & \multirow{2}{*}{ NA } & \multicolumn{4}{|c|}{ Assessment } & \multirow{2}{*}{ Comments on Assessment } & \multirow{2}{*}{ Plans for Improvement } \\
\hline & & $\mathrm{O}$ & LO & LNO & NO & & \\
\hline \multicolumn{8}{|l|}{ 0. Prerequisites of quality } \\
\hline $\begin{array}{l}0.1 \text { Legal and institutional } \\
\text { environment }\end{array}$ & & $X$ & & & & & \\
\hline 0.2 Resources & & & $X$ & & & $\begin{array}{l}\text { Limited access to Internet and telephone } \\
\text { calls. Flattening of the salary scale may } \\
\text { negatively impact staffing. }\end{array}$ & $\begin{array}{l}\text { Access to Internet and telephone } \\
\text { communications has been improved. }\end{array}$ \\
\hline 0.3 Relevance & & & $\mathrm{X}$ & & & $\begin{array}{l}\text { No formal consultation process with } \\
\text { users of monetary statistics. }\end{array}$ & \\
\hline 0.4 Other quality management & & $\mathrm{X}$ & & & & & \\
\hline \multicolumn{8}{|l|}{ 1. Assurances of integrity } \\
\hline 1.1 Professionalism & & $\mathrm{X}$ & & & & & \\
\hline 1.2 Transparency & & $\mathrm{X}$ & & & & & \\
\hline 1.3 Ethical standards & & $X$ & & & & & \\
\hline \multicolumn{8}{|l|}{ 2. Methodological soundness } \\
\hline 2.1 Concepts and definitions & & $\mathrm{X}$ & & & & & \\
\hline 2.2 Scope & & & $\mathrm{X}$ & & & SAFIs not included in the ODC survey. & $\begin{array}{l}\text { In coordination with the SPSI, accounts of } \\
\text { SAFIs will be included in the ODC survey } \\
\text { (short-term). }\end{array}$ \\
\hline 2.3 Classification/sectorization & & & $\mathrm{X}$ & & & $\begin{array}{l}\text { SAFIs classified as OFCs rather than as } \\
\text { ODCs. } \\
\text { No breakdown between other } \\
\text { nonfinancial corporations, and other } \\
\text { resident sectors. } \\
\text { Some problems of sectorization and } \\
\text { improper use of the residence criterion } \\
\text { by ODCs. }\end{array}$ & $\begin{array}{l}\text { The SBFE already instructed ODCs to report } \\
\text { SAFIs in a new category. } \\
\text { The SBFE already instructed ODCs to } \\
\text { separate accounts of nonfinancial } \\
\text { corporations and other resident sectors. } \\
\text { The SSMF will work closely with the SBFE } \\
\text { and the reporting institutions to correct the } \\
\text { detected mistakes (short-term). }\end{array}$ \\
\hline 2.4 Basis for recording & & $\mathrm{X}$ & & & & & \\
\hline
\end{tabular}


Table 5. Bolivia: Data Quality Assessment Framework (July 2003): Summary of Results for Monetary Statistics (Compiling Agency: Central Bank of Bolivia)

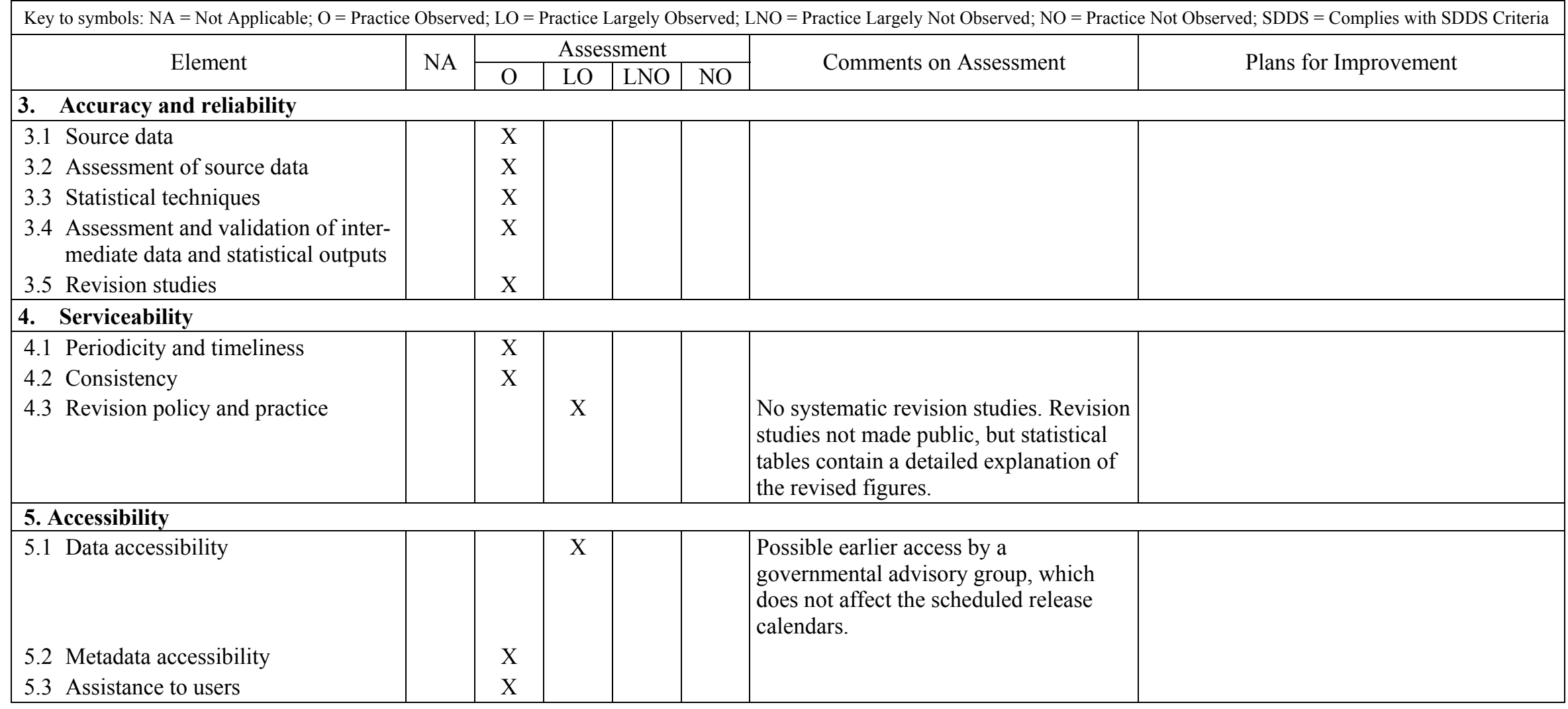




\section{Balance of Payments Statistics}

\section{Prerequisites of quality}

\section{$0.1 \quad$ Legal and institutional environment}

\subsubsection{The responsibility for collecting, processing, and disseminating the statistics is clearly specified}

Although not directly stated in any specific regulation, the Central Bank of Bolivia (CBB) has been responsible for collecting, processing, and disseminating balance of payments (BOP) statistics since 1938 and is publicly recognized as the sole institution with this responsibility. The CBB draws its authority to collect information needed to carry out its mandate from the Law of the Central Bank of Bolivia (Law 1670 of October 31, 1995). Article 40 of the CBB Law establishes (1) the obligation of the Superintendency of Banks and Financial Entities (SBFE) to provide to the $\mathrm{CBB}$ with all the information received from banks and other financial institutions; and (2) mandatory data reporting to the CBB of all information requested by the $\mathrm{CBB}$ from banks and other financial intermediaries. Article 21 establishes the CBB's responsibility for recording public and private external debt. Article 43 of the CBB Law establishes that the CBB shall publish periodically economic and financial statistics within the scope of its responsibilities. No law is in conflict with the authority of the CBB to compile BOP statistics.

Within the CBB, the Balance of Payments Department (BPD) is responsible for compiling Bolivia's BOP and international investment position (IIP) statistics. ${ }^{17}$ The BPD belongs to the External Sector Deputy Management Office (SSE) of the Economic Policy Advisory Office (APEC). Working arrangements between the BPD, other departments of the CBB, and other data-producing agencies are consistent with the assignment of responsibility.

\subsubsection{Data sharing and coordination among data-producing agencies are adequate}

Procedures are in place to facilitate effective and timely flow of source data to the CBB for the compilation of BOP statistics. Official data-producing agencies that regularly provide administrative source data include: the National Statistics Institute (NSI); the Vice Ministry of Public Investment and External Financing; the state-owned oil company Yacimientos Petroliferos Fiscales Bolivianos (YPFB); the SBFE; the Superintendency of Pensions, Securities, and Insurances (SPSI); and several ministries.

The BPD has also established working arrangements with the NSI for conducting surveys on international travel and foreign direct investment (FDI). Nevertheless, under these working

\footnotetext{
${ }^{17}$ This responsibility is clearly established in the CBB's Functions and Procedures Manual of October 2005, which is not disseminated to the public.
} 
arrangements, the last travel survey was conducted in 2003 and the last FDI survey in 2005. In 2006, the CBB decided to directly conduct the Foreign Private Capital Survey (FPC survey) requesting FDI and other external assets and liabilities data (portfolio investment and other investments), as well as selected international services. The NSI and the CBB have renewed their agreement for resuming the international travel survey during 2007. Contacts (mainly through technical meetings) are maintained with other data-producing agencies to promote understanding of data requirements, avoid duplication of efforts, and foster intermediate data consistency.

\subsubsection{Individual reporters' data are to be kept confidential and used for statistical purposes only}

The $\mathrm{CBB}$ Law requires the $\mathrm{CBB}$ staff to respect strict confidentiality regarding data. Article 80 establishes that (1) CBB's Board members and staff must keep secret all matters and operations of the $\mathrm{CBB}$ and financial institutions, as well as documentation and reports that are known due to their functions; (2) these obligations are applicable after retirement and/or separation from the $\mathrm{CBB}$, and (3) penalties against staff who discloses confidential data, including destitution and legal sanctions.

The CBB's Internal Regulation of Personnel, approved by the CBB Board Resolution 037/2002, bans any break of confidentiality regarding matters, operations, documentation, and reports of the $\mathrm{CBB}$ and other institutions (Article 7) and establishes sanctions - from fines to destitution - if confidentiality is infringed (Article 51). In compliance with the CBB's Internal Regulation of Personnel, all CBB staff must sign a Confidentiality Commitment form at the beginning of every year. Additionally, Article 3 of the CBB's Code of Conduct, approved by the Board Resolution 090/2001, establishes ethical principles for CBB staff including confidentiality issues.

Furthermore, data from surveys and direct reporting to the CBB are kept confidential. When requesting data from third parties, the $\mathrm{CBB}$ clearly states that all data and documentation submitted to the $\mathrm{CBB}$ are only for statistical purposes and will only be disseminated in aggregate figures. Access to the $\mathrm{CBB}$ database is guarded. Computers used by BPD staff require passwords and access to data by third parties requires special permission. The CBB's Department of Systems Security is responsible for managing the security of computer systems.

\subsubsection{Statistical reporting is ensured through legal mandate and/or measures to encourage response}

Although there is no legislation that explicitly enforces data reporting by the private sector to the CBB for BOP statistics, the CBB Law includes several articles that provide a legal basis for this endeavor. Article 40 of the CBB Law establishes that banks and other financial institutions are mandated to submit directly to the CBB monetary and other information required by the $\mathrm{CBB}$ in its creditor condition, as well as other information requested directly by the $\mathrm{CBB}$ President regarding the financial situation of an entity. Article 20 of the CBB 
Law provides for the $\mathrm{CBB}$ to regulate the international financial operations of individuals, and public and private sector entities. The BPD has invoked Article 20 when private sector entities express concern about the legal basis for data reporting to the CBB.

The CBB receives responses to the forms sent out to the private sector for collecting data on international transactions and positions on a regular basis. In late 2006, the CBB initiated a comprehensive quarterly FPC survey (FDI, other external assets and liabilities, and selected services). The response rate to the FPC survey is about 80 percent, although the deadline for responding the FPC survey has not been reached yet. This is the result of well-established communication channels created by the $\mathrm{CBB}$ with the private sector. A number of measures to encourage response are in place, including (1) staff visits to surveyed entities; (2) inclusion of data previously reported in every survey and reporting form sent to respondents, in order to facilitate reporting; (3) provision of consolidated information to surveyed enterprises; (4) making available CBB's statistical publications; and (v) provision of prompt assistance to respondents from BOP compilers.

Recommendation: Include in $C B B$ 's questionnaires and direct reporting forms for BOP compilation references to the legal basis for collecting information, including the confidentiality of reported data.

\section{$0.2 \quad$ Resources}

\subsubsection{Staff, facilities, computing resources, and financing are commensurate with statistical programs}

The BPD is comprised of nine professionals (including the department head). Staff qualifications are adequate. All professional staff have university degrees in economics and post-graduate degrees in economics or related fields. However, the human resources allocated to surveys'activities in the BPD have not been sufficient. Hence, the CBB has entered into agreements with other public entities (e.g., the NSI) in order to carry out survey activities. Staff have good understanding of concepts, procedures, and methodologies as set out in the fifth edition of the Balance of Payments Manual (BPM5). Most staff demonstrate dedication and initiative in their work. Most of the staff have participated in training courses related to BOP statistics organized by the IMF (both in Washington D.C. and at the Regional Training Center in Brasilia) as well as the Latin American Monetary Studies Center (CEMLA). Staff turnover has not been an issue, as individual experience in BOP statistics is on average six to seven years.

Working space, computer resources, and equipment are adequate to perform regular duties. Staff have their own computers connected to a main server with backup and system protection procedures. Staff has access to e-mail and Internet, although Internet access is restricted to two hours per day. Access to local phone calls is also limited to three minutes per call, which may become a serious constraint for the adequate implementation of surveys. Financial resources allocated to the compilation of BOP statistics have proved to be adequate. 
Recommendations: (1) Provide additional staff resources to the BPD to undertake tasks associated with the recent introduction of the CBB's Foreign Private Capital (FPC) survey; and (2) improve BPD staff telephone communications and Internet access.

0.2.2 Measures to ensure efficient use of resources are implemented

The $\mathrm{CBB}$ evaluates staff performance once a year. From time to time, the $\mathrm{CBB}$ has required outside technical assistance (mainly from the IMF, but also from other international institutions such as CEMLA, Debt Relief International (DRI), and Development Finance International (DFI)) to evaluate statistical methodologies, compilation systems, and debt sustainability analysis. Efficiencies are primarily sought through continuous reviews of work processes and by encouraging consistent concepts and methodologies across the different CBB units involved in the production of statistics.

\subsection{Relevance}

\subsubsection{The relevance and practical utility of existing statistics in meeting users' needs are monitored}

There is no structured and periodic process of consultation with data users regarding specific aspects of BOP data, such as their usefulness in terms of detail and/or the extent to which data meet users' needs. Nevertheless, users are consulted on an ad-hoc basis. For example, participants in a methodological seminar about the new FPC survey organized by the CBB in 2006 provided very useful feedback on the subject. Data users can direct inquiries and concerns to the area responsible for producing data on the $\mathrm{CBB}$ website.

CBB staff participate on a regular basis in regional and international BOP statistics meetings and workshops hosted by international institutions such as CEMLA, DRI, DFI, IMF and the Andean Community of Nations (CAN), among others. These meetings have proved to be very important in order to evaluate current practices and to adjust BOP compilation practices to international standards.

Recommendation: Establish regular procedures to obtain users' feedback on the relevance of BOP statistics and emerging data needs (preferably through users' surveys).

\subsection{Other quality management}

\subsubsection{Processes are in place to focus on quality}

CBB management and staff are aware that quality is an essential component of the statistical work and of the importance of technical training in creating analytical skills among staff, resulting in higher quality in every day activities. The CBB management encourages participation in training programs and other events that result in productivity gains among CBB staff. After participation in training activities, CBB staff provide lectures on the training subject opened to all CBB staff. For example, the CBB staff participated in several seminars 
and workshops on BOP, FDI, international trade in services, and external debt statistics organized by ANDESTAD (joint CAN-European Union Project for Statistical Harmonization in the Andean region). The CBB staff also participated in seminars on remittances organized by the World Bank-BIS and CEMLA-IDB. These seminars were very effective in terms of enhancing staff's skills.

\subsubsection{Processes are in place to monitor the quality of the statistical program}

The CBB is committed to monitoring the quality of ongoing statistical activities. To this end, each BPD staff is in charge of providing the external sector management with the details of the data reported by each sector under his/her responsibility. The compilation and dissemination of quarterly BOP, IIP, and private sector debt data, and the country's efforts to subscribe to the SDDS further demonstrate this commitment. Currently, the CBB is in the process of establishing a comprehensive macroeconomic database that will include BOP and IIP data.

Recommendation: Prepare monthly reports to inform management of the quality of data based on direct reporting and surveys (surveys' response rate, coverage, response errors, etc.).

\subsubsection{Processes are in place to deal with quality considerations in planning the statistical program}

Quality issues are taken into account when planning the statistical program and addressed when implementing surveys and reports (e.g., trade-offs among timeliness and accuracy/ reliability). The introduction of the quarterly FPC survey in November 2006 is evidence of how the CBB responds to the identification of problems with the data. The compilation and dissemination of quarterly BOP, IIP, and external debt data, and monthly reserves template data as well as the country's efforts to subscribe to the SDDS further demonstrate this commitment.

\section{Assurances of integrity}

\subsection{Professionalism}

\subsubsection{Statistics are produced on an impartial basis}

Professional considerations guide the selection of methods for compiling and disseminating BOP statistics. Article 1 of the CBB Law states that the CBB is a public autonomous institution and the only monetary and foreign exchange authority of Bolivia. Independence in data compilation is clearly recognized as essential to credibility of statistical results and is strongly supported by the CBB management. 
Professional competency plays a key role in recruitment and promotion policies, which follow well established standards regarding academic credentials, aptitude, knowledge, and experience.

CBB staff have attended courses and seminars on methodology and data compilation provided by international organizations such as the IMF, CAN, CEMLA, DFI and DRI, covering BOP, external debt, foreign direct investment, international trade in services, remittances, and international reserves template statistics.

Research and analysis are encouraged by the CBB. For example, the CBB's Analysis Magazine contains articles prepared by $\mathrm{CBB}$ staff on specialized issues related to relevant macroeconomic issues such as Bolivia's Debt Relief Under the HIPC Initiative.

\subsubsection{Choices of sources and statistical techniques as well as decisions about dissemination are informed solely by statistical considerations}

The choice of data sources, methodologies, and statistical techniques is based solely on statistical considerations in line with the BPM5. Likewise, decisions about data dissemination are based solely on statistical considerations.

The $\mathrm{CBB}$ has been actively participating in regional workshops (e.g., CAN) aiming to coordinate methodologies and share experiences regarding data compilation in areas such as international trade in services, remittances, foreign direct investment, public external debt, and BOP statistics.

\subsubsection{The appropriate statistical entity is entitled to comment on erroneous interpretation and misuse of statistics}

The CBB monitors media coverage of its data and, when deemed necessary, comments on erroneous interpretation and/or misuse of the statistics in the media. The CBB aims to prevent misinterpretation of BOP statistics by providing explanatory material and brief analysis in its publications.

\subsection{Transparency}

\subsubsection{The terms and conditions under which statistics are collected, processed, and disseminated are available to the public}

General terms under which BOP statistics are collected and disseminated are available to the public on the CBB website (www.bcb.gov.bo), including the criteria of data confidentiality. In particular, the semiannual publication External Sector Bulletin (available in print and on the CBB website) provides information about the terms and conditions under which BOP statistics are produced, including methodology, and source data. 
Recommendation: Enhance the description in the External Sector Bulletin of the terms under which BOP statistics are compiled and disseminated.

\subsubsection{Internal governmental access to statistics prior to their release is publicly identified}

Quarterly BOP data are presented twice yearly for informative purposes to the CBB's Board of Directors meeting immediately prior to their public release on the CBB website, which takes place 45 days after the end of the reference quarter. The Macroeconomic Group ${ }^{18}$ that meets periodically to monitor the macroeconomic and financial developments receives the latest available monetary and financial information that may or may not have been published on the CBB website. This practice may generate in some cases internal government access prior to their dissemination to the public, but with no interference with their pre-scheduled public dissemination. This practice is publicly identified in the CBB metadata posted on the CBB website. If requested, quarterly BOP data provided for the Macroeconomic Group meeting correspond to the latest published data.

\subsubsection{Products of statistical agencies/units are clearly identified as such}

BOP statistics are clearly identified as a CBB product, with CBB publications identifying the specific unit responsible for their compilation, and when applicable, other institutions that provide the main source data (e.g., NSI for data on goods export and imports).

\subsubsection{Advanced notice is given of major changes in methodology, source data, and statistical techniques}

Important changes in the methodology and source data to compile BOP statistics are made known to the public in advance. For example, the introduction of the FPC survey in 2006 was informed in advance to the public through an official communiqué of the CBB. Otherwise, changes are informed to the public at the time of the first release of the publication External Sector Bulletin.

Recommendation: Reinforce the practice of providing advanced notice of major changes in the compilation of BOP statistics.

\subsection{Ethical standards}

\subsubsection{Guidelines for staff behavior are in place and are well known to the staff}

The CBB's Code of Conduct, approved by Board Resolution 090/2001, establishes ethical principles for $\mathrm{CBB}$ staff, including integrity, fidelity, impartiality, professional independence,

\footnotetext{
${ }^{18}$ Currently, the Macroeconomic Group comprises the Minister of Finance, the CBB President, the Minister of Planning, the Deputy Ministers of Budget, Treasury, Tax Policy, Public Investment, and Pensions, and the Executive Directors of NSI, UDAPE, UPF, and the Fiscal Analysis Network (RAF).
} 
confidentiality, objectivity, prudence, respect, responsibility, transparence, and truthfulness. The Code of Conduct also establishes obligations, prohibitions and incompatibilities, sanctions, and an Ethics Committee. The CBB's Internal Regulation of Personnel establishes the rights and obligations for CBB staff. CBB staff have been provided with a copy of the Code of Conduct and the Internal Regulation of Personnel.

Furthermore, the CBB as part of the public sector is subject to the Law of Public Personnel (Law 2027), which sets out the legal framework for public service's rights and responsibilities, including ethical standards applicable to all public sector employees.

\section{Methodological soundness}

\subsection{Concepts and definitions}

\subsubsection{The overall structure in terms of concepts and definitions follows internationally accepted standards, guidelines, or good practices}

The overall conceptual framework conforms to guidelines outlined in the BPM5. The BOP statement is constructed taking into account the double-entry system as the basic principle, and the net residual is embedded in the errors and omissions item. A clear distinction is made between the income component and the goods and services components. Resident institutional units are defined in conformity with the BPM5 and related to those that have a center of economic interest in the country. The basic criterion that defines foreign direct investment enterprises in Bolivia is the possession of at least ten percent ownership of an enterprise by a nonresident. In 1998, the CBB converted BOP statistics to the BPM5 format, revising the data from 1990 onwards.

\section{$2.2 \quad$ Scope}

2.2.1 The scope is broadly consistent with internationally accepted standards, guidelines, or good practices

The scope of the BOP statistics is broadly consistent with guidelines outlined in the BPM5. The CBB aims to register all resident-nonresident transactions. Nevertheless, unrecorded trade data (contraband, shuttle trade, and illegal trade) are not included in the BOP statistics.

In general, government bonds and other bonds issued locally and held by nonresidents are not included as external liabilities in the BOP data, due to the lack of information on the current holder. Similarly, nonresidents' deposits in the financial system (e.g., consulates and embassies, and international organizations) are excluded from the BOP data, due to the lack of identification between resident and nonresident transactions.

Recommendations: (1) In consultation with the NSI, develop a methodology to include unrecorded trade and its counterpart transactions in BOP statistics; (2) identify, in coordination with the MOF, ways to gather information on the ultimate holder of government 
bonds issued locally; and (3) assess the extent to which nonresidents' deposits could be identified from total bank deposits in SBFE data.

\section{Natural gas, petroleum, and related products}

Exports and imports of hydrocarbons are covered in trade statistics compiled by the NSI from Customs data. Hydrocarbons exports comprise natural gas, petroleum, and other related products (gasoline, liquid gas, and fuel oils). On the other hand, imports of fuels and other related products are separately identified in total imports. Other transactions of the hydrocarbons sector in the services, income, and financial accounts are included in the BOP but are not separately identified, as the $\mathrm{CBB}$ does not compile a BOP of the hydrocarbons sector.

\subsection{Classification/sectorization}

\subsubsection{Classification/sectorization systems used are broadly consistent with internationally accepted standards, guidelines, or good practices}

Classification and sectorization systems used for BOP statistics are broadly consistent with the guidelines outlined in the BPM5. However, more detailed classification is needed for some services, and there are instrument misclassifications (e.g., trade credits are included in loans). All transfers are classified as current transfers, given the difficulty of identifying the type of transfer (capital or current) in the data source. ${ }^{19}$ The recording of external debt relief transactions does not follow the BPM5 guidelines (e.g., the cancellation of external debt liabilities is to be recorded as capital transfers in the capital balance accounts with the corresponding counterpart in the current and/or financial account as it corresponds).

Most institutional units are classified and attributed to the relevant sector according to the BPM5. Nevertheless, some minor adjustments in the sectorization of institutional units are needed; e.g., FONDESIF and NAFIBO are classified as banks rather than as other sectors (nonbank financial corporations), and private investment funds, credit unions, savings and loans associations, and the investment funds management societies are classified as other sectors (nonbank financial corporations) rather than as banks. ${ }^{20}$

\footnotetext{
${ }^{19}$ According to the BPM5, if there is a serious doubt as to the classification of a cash transfer as current or capital, it should be classified as current transfer (BPM5, paragraph 344).

${ }^{20}$ The presentation of the balance of payment's four institutional sectors is available in the BPM5, Appendix II (page 145). In particular, the banking sector is identical with "other depository corporations" in the monetary statistics. Therefore, in addition to commercial banks, the banking sector comprises institutions engaged in financial intermediation as a principal activity and having liabilities in the form of deposits or financial instruments that are close substitutes for deposits (e.g., savings banks, savings and loans associations, credit unions and cooperatives).
} 
Recommendation: (1) Align the classification of transactions in services and transfers, and the sectorization of institutional units with the BPM5 guidelines; and (2) review the external debt relief data recording in line with the BPM5, including the recording of debt forgiveness in the capital account.

\section{Reserves template}

In June 2006, the CBB initiated the monthly dissemination of the International Reserves and Foreign Currency Liquidity Template (Reserves template) with one month lag. Bolivia's reserves template is broadly in line with the international guidelines. ${ }^{21}$

Recommendation: Align the classification and coverage of the reserves template to the IMF guidelines, ${ }^{22}$ as follows:

- Exclude the RAL Fund ${ }^{23}$ (US\$ 489.9 million) from Section I. B Other foreign currency assets and from Section III 1.B Other contingent liabilities.

- Include all short-term foreign-currency deposits of the financial sector with the CBB as predetermined short-term net drains on foreign currency assets in Section II.1 Outflows.

- Exclude from Section II.3 Other trade credit (+) the positive balances with ALADI's Agreement of Reciprocal Payments and Credit to avoid double counting with Section I.A.5.

- When applicable, include the negative balances with ALADI's Agreement of Reciprocal Payments and Credit as predetermined short-term net drains on foreign currency assets in Section II.3 Other trade credit (-).

- When applicable, include in Section IV. 1 b) short-term domestic-currency debt indexed to foreign exchange rates and short-term financial instruments denominated in foreign currency but settled in domestic currency.

- The currency composition of official reserve assets disclosed in Section IV.2 a), according to those currencies in the SDR basket and those not in the SDR basket, should match the amounts reported in Section I.A.

- Official reserve assets in gold should be reclassified from assets in currencies not in the SDR basket to assets in currencies in the SDR basket within Section IV.2 a). ${ }^{24}$

\footnotetext{
${ }^{21}$ The reserve template is a prescribed data category of the SDDS. Reserve template guidelines are available at http://dsbb.imf.org/Applications/web/sddsguide/

${ }^{22}$ Some of these recommendations have been already implemented by the CBB during the data ROSC mission. Guidance on the recording of capital contributions to the FLAR in the reserves template was provided after the mission in a letter from the STA's Balance of Payments and External Debt Division II to the CBB's SSE on March 5, 2007.

${ }^{23}$ To comply with banking regulations, the liquidity requirements denominated in foreign exchange are held by domestic banks mainly in the form of portfolio investment assets with nonresidents in the Liquid Assets Requirements Fund (RAL Fund). Thus, these funds are not under the direct control of the monetary authorities. The RAL Fund is classified in the BOP and IIP statistics under banks' assets abroad (portfolio investment). Similar treatment is applied in the monetary and financial statistics.
} 


\subsection{Basis for recording}

\subsubsection{Market prices are used to value flows and stocks}

Data are compiled in U.S. dollars. As specified in BPM5, transactions denominated in other currencies are converted into U.S. dollars using the mid-point exchange rate prevailing in the market on the transaction date and/or for the applicable period.

In general, where transactions estimates are derived from stock data, the CBB aims to value the transaction excluding valuation and other changes. Nevertheless, flow data derived from stocks for nonbank deposits abroad (assets) are not adjusted for exchange rate valuation changes. Most transactions are valued at market prices and, where information is not available, at nominal or book values. For instance, total imports and exports are valued on a f.o.b. basis, monetary gold at market prices, and nontradable debt instruments at nominal value. The net worth of the company is used for FDI valuation purposes.

Recommendation: Adjust flow data derived from BIS stocks data on nonbank deposits abroad for exchange rate valuation changes.

\section{Natural gas, petroleum, and related products}

Trade data on petroleum and related products are recorded by Customs at market prices and on natural gas at the contract prices agreed between the Government of Bolivia and the governments of Brazil and Argentina. Transactions in equity capital of direct investment enterprises involved in natural gas, petroleum, and related products are recorded at market value. In general, equity stocks are recorded at book value and, to the extent possible, according to the enterprises' net worth.

\subsubsection{Recording is done on an accrual basis}

Most BOP transactions are recorded on an accrual basis, as established in the BPM5, and the change in ownership is the governing principle that identifies when a transaction takes place. For example, goods are registered when entering customs (proxy for the change in ownership of goods); reinvested earnings on direct investment are recorded in the periods when earned; interest on private sector external debt is recorded when interest accrues; loan drawings are recorded at the time of actual disbursement; and loan repayments when due for payment. Nevertheless, interest on public sector external debt is recorded on a due-for-payment basis rather than when interest accrues, and dividends are recorded when paid rather than when declared payable.

\footnotetext{
${ }^{24}$ See International Reserves and Foreign Currency Liquidity Guidelines For A Data Template, Appendix V, paragraph 10.
} 
Recommendations: (1) In coordination with the GOI, apply the accrual principle for recording interest on public external debt; and (2) record dividends when declared payable.

\subsubsection{Grossing/netting procedures are broadly consistent with internationally accepted standards, guidelines, or good practices}

In accordance to the $B P M 5$, most current transactions are recorded on a gross basis while financial account transactions are recorded on a net basis, separately for the individual asset and liability components.

\section{Accuracy and reliability}

\subsection{Source data}

3.1.1 Source data are obtained from comprehensive data collection programs that take into account country-specific conditions

The data collection programs to compile BOP statistics are adequate. Nevertheless, source data for certain services and financial transactions may be improved. Data collection based on surveys are not used extensively for international trade in services, due to limitations in human resources and because of the lack of a comprehensive and up-to-date business register that can provide the basis for sample surveys.

The core data sources are broadly sufficient to compile the BOP statistics. Data sources include: (1) CBB data; (2) administrative data from other government agencies; (3) surveys; (4) direct reporting mainly from nonfinancial enterprises; and (5) information obtained from foreign and international financial institutions.

The BPD obtains statistical data from other $\mathrm{CBB}$ areas, namely:

- International Operations Management Office (GOI), mainly for public and private sector external debt data (flows and stocks) based on the DMFAS database (UNCTAD's debt management software);

- Monetary and Fiscal Sector Deputy Management Office (SSMF), mainly for data on assets and liabilities of the financial sector, based on detailed data submitted by the SBFE and on the CBB's own records. ${ }^{25}$

- Accounting Deputy Management Office, mainly for CBB's reserves assets (flows and stocks data), ${ }^{26}$ contributions to international organizations, and official grants disbursed through CBB's accounts.

\footnotetext{
${ }^{25}$ In addition, the Gold and Foreign Exchange Position Statement from the CBB's monetary accounts is used to determine prices and foreign exchange variations of the reserve assets.
} 
- Financial Entities Management Office, mainly for financial services of banks and other financial sector institutions.

The BPD also obtains information from other government agencies, namely:

- National Statistics Institute (NSI), for goods exports and imports, including freight, insurance, and other expenses based on Customs data. The NSI also provides data on the number of international passengers by type of transport (disaggregated between nationals and foreigners) based on National Service of Migration information.

- Ministry of Foreign Affairs, for government services n.i.e., official transfers, and Bolivian migrants to other economies.

- Ministry of Mining, mainly for detailed information on mineral exports (value, volume, unit price, etc.).

- Ministry of Hydrocarbons, mainly for detailed information on hydrocarbons exports (value, volume, unit price, etc.) and other related information.

- Treasury, for contributions to international organizations.

- Vice Ministry of Public Investment and External Financing, for data on official current transfers.

- Bolivian state-owned oil company Yacimientos Petrolíferos Fiscales Bolivianos (YPFB), for detailed information on hydrocarbons exports and investment in the sector.

- SPSI, for data on insurance services other than freight, and investment income.

- Superintendency of Telecommunications, for data on communication services (credits and debits).

- National Post Office, for information on postal and courier services.

- Ministry of Labor, mainly for information on border and seasonal workers in Bolivia and in neighboring countries.

Under a working agreement with the $\mathrm{CBB}$, the NSI has been conducting two surveys that provide essential information for BOP statistics:

- Quarterly FDI surveys during 1998-2004. The working arrangement for the FDI surveys also included the Ministry of Foreign Trade and Investment and the Private Entrepreneurs Confederation of Bolivia (Confederación de Empresarios Privados de Bolivia). Due to problems in the implementation of the NSI's FDI survey, the CBB estimated FDI flows and stock data in 2005 based on a questionnaire sent to a small number of enterprises. In November 2006, the BPD, jointly with the GOI, initiated a Foreign Private Capital Survey (FPC survey) that requests information on FDI, portfolio investment, ${ }^{27}$ and other external assets and liabilities, and international services to more than 300 enterprises. The FPC survey will be conducted by the CBB quarterly.

\footnotetext{
${ }^{26}$ The CBB has included Bolivia's contribution to the FLAR (about US\$161 million) in the reserve assets until December 2005. From 2006 onwards the contribution to FLAR is included as other external assets of the CBB.

${ }^{27}$ Portfolio investment data include transactions of the Liquid Assets Requirements Fund (RAL Fund) maintained by commercial banks and other financial institutions abroad.
} 
- Travel surveys in 2000 and 2003. The working arrangement for the travel survey also included the Vice Ministry of Tourism and the National Service of Migration. The travel survey will be resumed by the NSI in 2007 and conducted both in high and in low season. Currently, the questionnaires are being updated based on the results obtained from previous surveys. The travel survey is targeted to residents traveling abroad and nonresidents visiting Bolivia.

Finally, the BPD also obtains information from direct reporting (questionnaires) and/or data published by international financial institutions, as follows:

- Nonfinancial enterprises, for data on communications, financial, and other services.

- Foreign embassies and international organizations accredited in Bolivia, for data on government services and current transfers.

- Private and official donors, for data on grants (current and capital).

- Banks and money transfer companies (such as MoneyGram and Western Union), for data on workers' remittances (credits and debits).

- Private banks and other financial institutions, for quarterly data on other investment.

- Bank for International Settlement (BIS), for stock data of nonbank deposits in nonresident banks.

Recommendations: (1) Initiate quarterly FPC surveys in 2007, identifying improvements in design, data validation, and sample techniques, based on the results of the 2006 FPC survey; (2) prepare a comprehensive and up-to-date business register for sample surveys; (3) reinforce the use of surveys and direct reporting data for services; and (4) resume in 2007 the semiannual travel survey, jointly conducted by NSI and CBB.

\section{Natural gas, petroleum, and related products}

The Customs administration is the only source data on exports and imports of natural gas, petroleum, and related products. Information on all other BOP transactions (services, investment income, direct investment, and other financial transactions) is compiled by the $\mathrm{CBB}$ based on surveys data and direct reporting from YPFB.

\subsubsection{Source data reasonably approximate the definitions, scope, classifications, valuation, and time of recording required}

Source data (administrative records, private sector surveys, and direct reporting) are broadly consistent with BPM5 guidelines. For example, information on external debt obtained from the GOI is broadly in line with the BPM5 and the guidelines of the External Debt Statistics: Guide for Compilers and Users (External Debt Guide). ${ }^{28}$ BPD staff are aware of the existing

\footnotetext{
${ }^{28}$ The External Debt Guide is available in English and translation into Spanish, Chinese, and French at http://www.imf.org/external/pubs/ft/eds/Eng/Guide/index.htm
} 
differences between source data definitions and those required for BOP compilation. Whenever it is necessary, and to the extent possible, the CBB adjusts data from various sources to improve coverage, classification, and valuation. For example, goods crossing Bolivian borders without changing ownership are excluded from BOP statistics (i.e., aircrafts under operational leasing).

\subsubsection{Source data are timely}

Generally, information for compiling BOP statistics is available on time for their dissemination according to the CBB's advance release calendar. For example, merchandise exports and imports are available one month after the period of reference. Public external debt data are available 15 days after the period of reference. However, occasionally, there are some delays in obtaining data from surveys and direct reporting. The latter is an aspect that the CBB continuously tries to minimize by a close follow up of information requirements to third parties. Contact points for each subject field are publicized in the case of questionnaires and surveys that the $\mathrm{CBB}$ regularly undertakes, at the end of each form.

Recommendation: Subject to staff availability and improvements in the telephone communications, employ more rigorous follow-up procedures to ensure the timely receipt of respondents' data.

\subsection{Assessment of source data}

3.2.1 Source data-including censuses, sample surveys and administrative records-are routinely assessed, e.g., for coverage, sample error, response error, and nonsampling error; the results of the assessments are monitored and made available to guide statistical processes

Accuracy of the data from surveys and direct reporting is routinely assessed. In the case of the FPC survey, data are confronted with other sources of information (balance sheets, industry reports, etc.) in order to check consistency. The effects of changes to questionnaires on survey estimates are assessed. Extreme values are confirmed with respondents. The source data are analyzed for underreporting, in particular to review temporal consistency and consistency with related data sources. Accuracy of the information from administrative data (e.g., public and private external debt data, international trade of goods, financial sector's flows and stocks, reserve assets, etc), as well as other supplementary sources used to compile the BOP is routinely assessed.

\subsection{Statistical techniques}

\subsubsection{Data compilation employs sound statistical techniques to deal with data sources}

Compilation procedures are conducted to minimize coding, editing, and tabulation errors. Procedures for imputation and estimation techniques for nonresponse and missing information are employed, but improvements could be made. 
Recommendation: Review statistical techniques to adjust data for missing observations.

\subsubsection{Other statistical procedures (e.g., data adjustments and transformations, and} statistical analysis) employ sound statistical techniques

The $\mathrm{CBB}$ employs procedures to adjust data from various data sources to improve coverage, classification, and valuation in line with BPM5 guidelines:

- NSI trade data based on Customs information are adjusted with respect to coverage, valuation, and timing to accord with BPM5 concepts. ${ }^{29}$

- Passengers' land transportation services are calculated using NSI information and average ticket prices.

- Travel services are calculated based on NSI administrative data on passengers and average length and cost of stay estimated from the travel survey conducted in 2003.

- Government services n.i.e., are based on the number of employees working in foreign embassies and consulates accredited in Bolivia and average wage estimates.

- Data on investment income of FDI are based on estimated rates of return.

- Workers' remittances through informal channels are estimated to amount up to 20 percent of those made through formal channels. ${ }^{30}$

- Estimates for migrant transfers are made based on administrative data available from the Ministry of Foreign Affairs.

Recommendations: (1) Continue efforts to improve data collection and estimation techniques for workers' remittances ${ }^{31}$ and other transfers, and certain services and financial transactions; and (2) review estimates on direct investment with the view to avoid overestimation of investment income and reinvested earnings.

\subsection{Assessment and validation of intermediate data and statistical outputs}

\subsubsection{Intermediate results are validated against other information where applicable}

In general, intermediate results are validated against other independent data sources, including, for example:

\footnotetext{
${ }^{29}$ Nevertheless, the CBB needs to develop a methodology, in consultation with the NSI, to include unrecorded trade (smuggling, shuttle trade, and illegal trade) in BOP statistics (see 2.2.1).

${ }^{30}$ The CBB is participating in the IDB-CEMLA project to improve statistics on remittances.

${ }^{31}$ The mission recommends to continue work to further enhance the coverage of money transfer companies and to improve the estimation techiques, for example, by including related questions in relevant NSI surveys.
} 
- Information reported in the financial press is used to verify high-value direct investment and other transactions such as trade in services.

- FDI information and external private sector debt data are confronted with other sources of information (balance sheets, industry reports, etc.) in order to check consistency.

\subsubsection{Statistical discrepancies in intermediate data are assessed and investigated}

In general terms, the behavior of series is routinely assessed against related series but not in a systematic way, for instance:

- The c.i.f., and f.o.b., values for merchandise are confronted with freight ratios.

- Reported financial flow data are crosschecked with changes in the corresponding stock data collected for different IIP elements.

- Exports data from the Customs Office are confronted with data from YPFB and other public enterprises, sectoral organizations (e.g., mining sector), and private enterprises.

- Public external debt data, as well as some private external debt, are confronted with creditors' data.

\subsubsection{Statistical discrepancies and other potential indicators of problems in statistical outputs are investigated}

The CBB evaluates developments in errors and omissions in order to check for consistency between movements in the current, capital, and financial accounts on a regular basis. Comparisons with counterpart data-producing agencies are also carried out. For example, data on selected public and private external debt transactions are compared with data from multilateral creditors (the IDB, the IMF, and the World Bank). Data reconciliation with partner countries and international data sources is limited.

Recommendations: (1) In coordination with the GOI, compare data on selected external debt transactions with the Joint BIS-IMF-OECD-World Bank external debt table (available at http://www.jedh.org/) and the BIS locational banking statistics (available at http://www.bis.org/statistics/bankstats.htm); and (2) reconcile regularly trade data using partner-country data to adjust for possible differences in coverage of exports and imports.

\subsection{Revision studies}

3.5.1 Studies and analyses of revisions are carried out routinely and used internally to inform statistical processes (see also 4.3.3)

CBB staff routinely carries out analysis of revisions of BOP data in order to improve data quality. In general, no adequate documentation is maintained. Nevertheless, important revisions are well documented. For example, a recent detailed revision of statistics determined that data from the NSI regarding natural gas exports were not being valued on a f.o.b. basis. For BOP purposes, this adjustment was made and corrected since 2005. Few 
years ago, substantial imports of vehicles were being recorded by the NSI when these imports were legally regularized rather than when the change in property of goods took place. Data were revised according to BPM5 guidelines, and these revisions informed the statistical process accordingly.

Recommendation: Document studies and analyses of revisions and use these results to inform the statistical process.

\section{Serviceability}

\subsection{Periodicity and timeliness}

\subsubsection{Periodicity follows dissemination standards}

Although Bolivia is a GDDS participating country, the dissemination of quarterly BOP statistics meets the SDDS prescribed quarterly periodicity. The GDDS periodicity for BOP data is annual (but quarterly data are encouraged).

\subsubsection{Timeliness follows dissemination standards}

Likewise, the timeliness of BOP statistics meets the SDDS prescribed timeliness of one quarter after the reference period. Preliminary quarterly BOP are first disseminated 45 days after the end of the reference period through the Report on Balance of Payments and International Investment Position. Preliminary annual BOP data are released when fourth quarter statistics are disseminated. The GDDS timeliness for BOP data is six months after the reference period. ${ }^{32}$

\subsection{Consistency}

\subsubsection{Statistics are consistent within the dataset}

BOP statistics are consistent within the dataset. Concepts, definitions, and classifications are the same for producing quarterly and annual statistics. Data regarding financial transactions of the BOP are consistent with changes in IIP data. Every quarter, the BPD prepares a table reconciling the BOP transaction data with the changes in the IIP position. Minor differences were identified for 2004-2005 data.

\footnotetext{
${ }^{32}$ Bolivia disseminates quarterly IIP data 45 days after the reference quarter. The SDDS prescribes the dissemination of annual IIP data within nine months after the reference year, and encourages the dissemination of quarterly IIP data within three months after the reference quarter. Currently, less than one-third of IIP data compiler countries are disseminating quarterly IIP statistics.
} 
Over the long run, the net errors and omissions item of the BOP has been constantly negative. It has been relatively low in 1996 (- US\$23 million) and 2000 (- US\$54 million) but quite large in 2002 (- US\$643 million) and 2004 (- US\$628 million). During 1995-2005, errors and omissions averaged -4 percent of the gross domestic product (GDP), -8.5 percent of the international trade of goods and services, and were equivalent to 146 percent of Bolivia's current account deficit. ${ }^{33}$ The CBB estimates that the errors and omissions item will be relatively low in $2006 .{ }^{34}$ The BPD monitors developments on errors and omissions and is well aware that further improvements in source data and estimation techniques are needed.

Recommendations: (1) Closely monitor the BOP errors and omissions; and (2) produce and disseminate on a regular basis a summary table on BOP and IIP data consistency (identifying initial stock, transactions, other changes, and final stock).

\subsubsection{Statistics are consistent or reconcilable over a reasonable period of time}

BOP statistics are consistent over time. Annual data are available since 1990 and quarterly data since 1997. In general, when changes in source data, methodology, or techniques are introduced, the CBB revises the historical series accordingly, as far back as possible. Methodological notes accompanying tables of BOP statistics in CBB publications identify the main breaks in statistics, such as the introduction of surveys and debt compilation methodologies in the case of debt relief, among others. Unusual changes in economic trends are also explained in CBB publications.

Recommendation: Revise the data series prior to 2006 in order to reclassify Bolivia's contributions to FLAR from reserve assets to other CBB's external assets.

\subsubsection{Statistics are consistent or reconcilable with those obtained through other data sources and/or statistical frameworks}

For the most part, BOP data are consistent or reconcilable with the international merchandise trade, monetary and financial statistics, GFS, and external debt. However, there are some differences with national account statistics that need further reconciliation. The APEC conduct a macroeconomic consistency exercise periodically in order to review the consistency between monetary, fiscal, and BOP data.

\footnotetext{
${ }^{33}$ During the same 1995-2005 period, the errors and omission item for MERCOSUR countries (Argentina, Brazil, Paraguay, and Uruguay) have averaged -0.2 percent of their GDP, -0.9 percent of their international trade in goods and services, and 10.8 percent of their current account balance. Similar behavior is observed for countries participating in the CAN (Bolivia, Colombia, Ecuador, and Peru).

${ }^{34}$ The CBB considers that the large errors and omissions item reflect short-term financial outflows in critical periods of financial disintermediation. In 2006, part of these resources are converted into domestic currency explaining the net increase of the CBB's reserve assets and banks' external assets.
} 
BOP statistics and merchandise exports and imports are largely consistent. Both statistics are based on the same data source (NSI data based on Customs information). Nevertheless, as explained before, BOP data include some adjustments to approximate the source data to the BPM5 guidelines. For example, exports and imports data are adjusted in order to obtain f.o.b., values from c.i.f., values and to exclude in BOP some service transactions recorded in Customs data (e.g., aircrafts under operational leasing).

National accounts and BOP statistics are reconcilable to the extent that the NSI uses BOP data in order to produce the "rest of the world" account. Nevertheless, the NSI adjusts these data by estimating unrecorded trade, among others. Other differences between BOP and national accounts time series result from the difference periodicity and timeliness of both datasets. NSI and the CBB are working to have more reconcilable figures.

The banking sector transactions in the BOP statistics are largely consistent with monetary and financial statistics. BOP data are based on relevant banking data reported by the SBFE for monetary and financial statistics purposes. The data on reserve assets of the CBB (flow and position) are also consistent between the two datasets.

Public external debt flows compiled and published by the CBB are consistent with fiscal data. The $\mathrm{CBB}$ is the official compiler of external debt statistics in Bolivia; this facilitates the reconciliation of stocks and flows with the MOF and other public sector agencies. Data on official transfers are reconciled with data from the Vice Ministry of Public Investment and External Financing, which is the official entity that manages such transfers.

Finally, BOP statistics are largely consistent with IIP data. BOP and IIP data are compiled and disseminated simultaneously by the CBB. Every quarter, the BPD conducts a full reconciliation exercise between BOP and IIP data (see 4.1.1 and 4.1.2). BOP data are also largely consistent with the corresponding external debt stocks data comprised in the IIP data.

Recommendations: (1) Establish regular mechanisms for enhancing data consistency with national accounts statistics; and.(2) prepare and disseminate a table on quarterly reserve assets reconciliation between monetary and BOP statistics.

\section{Natural gas, petroleum, and related products}

BOP data on exports and imports of natural gas, petroleum and related products are consistent with merchandise trade statistics. The only adjustment made to trade data is the correction on imports to adjust them to the f.o.b. value. Customs data are reconciled with hydrocarbons' exports and imports data provided by YPFB.

\subsection{Revision policy and practice}

\subsubsection{Revisions follow a regular and transparent schedule}

In general, the data revisions are associated with the availability of source data. The revision

cycle is predetermined and reasonably stable from year to year. Each quarter, BOP data for 
the previous four quarters are revised, and annual revisions are carried out when needed and applied to historical data as appropriate. Nevertheless, the revision cycle and the reasons underlying the cycle are not formally made known to the public.

Recommendations: (1) Strengthen data revision policies and practices; and (2) publicize the revision cycle for $B O P$ data on the $C B B$ website.

\subsubsection{Preliminary and/or revised data are clearly identified}

At the time of data dissemination, statistics are clearly identified as preliminary or revised.

\subsubsection{Studies and analyses of revisions are made public (see also 3.5.1)}

Analyses of revisions are mainly available within the CBB. When major data revision occur, comments and explanations are included in the corresponding CBB's BOP publication.

\section{Accessibility}

\subsection{Data accessibility}

5.1.1 Statistics are presented in a way that facilitates proper interpretation and meaningful comparisons (layout and clarity of text, tables, and charts)

BOP statistics are presented in a clear manner that facilitates proper interpretation. Commentaries on current-period developments are included, as well as on changes in methodology when appropriate. The CBB publishes BOP statistics in the Report on Balance of Payments and International Investment Position (quarterly), which is available 45 days after the end of the reference period. More detailed information and analysis of the BOP are disseminated in the External Sector Bulletin (semiannual), which is available with a fivemonth lag. BOP data are also published in the CBB's Monthly Bulletin and its quarterly Statistical Bulletin, which are available within one and three months after the end of the reference period, respectively, and in the Annual Report of the CBB. All these publication are available in hardcopy and on the CBB website (www.bcb.gov.bo).

BOP data are disseminated according to BPM5 standard components and analytical presentations. Additional series are available in electronic format (since 1980 in some cases) on the CBB website, and are disseminated to meet a range of users needs (e.g., FDI data by geographic area or debt flows by creditor and debtor entity). BOP data are also provided for international publications in specific formats (e.g., IMF, CAN, CEMLA, the Latin-American Reserves Fund (FLAR), and the United Nations System).

The CBB's External Sector Bulletin includes a wide range of information on BOP and related statistics, including:

- Summary BOP tables (BPM5 standard components and analytical presentation). 
- Summary and detailed tables on services, income, transfers (official and private), and financial account transactions (including FDI, portfolio investment, other investment, and reserves).

- Detailed tables on goods exports (value and volume) disaggregated by: (1) minerals, hydrocarbons, nontraditional products, and other products; (2) country of destination, (3) economic use of goods (consumption, intermediate, and capital goods); and (4) public and private sector.

- Detailed tables on goods imports include tables disaggregated by (1) use of goods (consumption, intermediate, and capital goods); (2) country of origin; and (3) public and private sector. Adjustments to imports made by the CBB to NSI data are identified in some of these tables.

- Detailed information on public external debt (short and long term) classified by debtor and creditor category, including disbursements, debt service (principal and interest), arrears, HIPC relief, outstanding debt and outstanding disbursements.

- Private external debt data by maturity, debtor, including disbursements, debt service (principal and interest), and outstanding debt.

- Summary tables on IIP data according to BPM5 standard components, including comparison with other South American countries.

Recommendations: In coordination with the GOI, (1) initiate the dissemination of the publicand publicly-guaranteed external debt service schedule recommended by the GDDS on the $C B B$ website; (2) initiate the dissemination of the SDDS prescribed external debt position data category (by institutional sector of the debtor, maturity, and type of instrument) on the $C B B$ website; (3) initiate participation in the World Bank's quarterly external debt statistics (QEDS) database; and (4) compile and disseminate other QEDS tables relevant for Bolivia in the $C B B$ website. The BPD may also (1) initiate the monthly reporting of the reserves template with one-month lag to the IMF's Statistics Department for its redissemination on the IMF website; and (2) disseminate monthly series of the reserves template on the $C B B$ website.

\subsubsection{Dissemination media and format are adequate}

Statistics are disseminated in formats aiming to suit users' needs and in ways that facilitate redissemination in the media. All CBB publications are available online (including excel formats when applicable). Current statistics and longer time series are easily available on the CBB website.

\subsubsection{Statistics are released on a preannounced schedule}

An advance release calendar is posted on the $\mathrm{CBB}$ website at the beginning of each year, and the BOP statistics are released punctually.

\subsubsection{Statistics are made available to all users at the same time}

Balance of Payments Statistics 
BOP statistics are made available to all users simultaneously through the CBB website.

\subsubsection{Statistics not routinely disseminated are made available upon request}

The CBB provides available unpublished BOP and other external sector statistics to users who request so, with due regard to confidentiality rules. No specific references are made in BOP publications regarding availability of unpublished data.

\subsection{Metadata accessibility}

5.2.1 Documentation on concepts, scope, classifications, basis of recording, data sources, and statistical techniques is available, and differences from internationally accepted standards, guidelines, or good practices are annotated

BOP metadata are available on the CBB website (in Spanish) as well as on the IMF's DSBB. In addition, the semiannual CBB publication External Sector Bulletin, also available online at the $\mathrm{CBB}$ website, includes a comprehensive sources and methods document. Metadata are also available in the IMF's Balance of Payments Yearbook.

Recommendation: Update the BOP metadata posted on the IMF website and the CBB website at least once every year and/or when important changes in methodology, data sources, estimation techniques, or data availability are implemented.

\subsubsection{Levels of detail are adapted to the needs of the intended audience}

Different levels of metadata are available to meet users' needs. In addition to the metadata referred to in the previous section, documentation on basic concepts and definitions on balance of payment statistics and other related statistics are available on the CBB website. More specialized analytical information is made public through a number of $\mathrm{CBB}$ publications. The Annual Report of the CBB (available also online) includes specific topics regarding BOP analytical and data issues. For example, the 2005 Annual Report included boxes with information and analysis on Merchandise exports 1995-2004 and Foreign direct investment in Bolivia 1996-2004.

\subsection{Assistance to users}

\subsubsection{Contact points for each subject field are publicized}

Prompt and knowledgeable service and support are available to users of statistics. The CBB website (which includes all CBB statistical publications) clearly identifies contact information for BOP and other external sector statistics (IIP, external debt, reserves, etc.), including name, position, address, telephone, facsimile, and e-mail address. CBB's hard copy publications only include a general contact point for all enquiries. 
5.3.2 Catalogs of publications, documents, and other services, including information on any charges, are widely available

A list of all publications is available on the CBB website, including the price of hard copies.

Balance of Payments Statistics 
Table 6. Bolivia: Data Quality Assessment Framework (July 2003): Summary of Results for Balance of Payments Statistics (Compiling Agency: Central Bank of Bolivia)

\begin{tabular}{|c|c|c|c|c|c|c|c|}
\hline \multirow{2}{*}{ Element } & \multirow{2}{*}{ NA } & \multicolumn{4}{|c|}{ Assessment } & \multirow{2}{*}{ Comments on Assessment } & \multirow{2}{*}{ Plans for Improvement } \\
\hline & & $\mathrm{O}$ & $\mathrm{LO}$ & LNO & $\mathrm{NO}$ & & \\
\hline \multicolumn{8}{|l|}{ 0. Prerequisites of quality } \\
\hline 0.1 Legal and institutional environment & & \multirow[b]{4}{*}{$\mathrm{X}$} & $\mathrm{X}$ & & & $\begin{array}{l}\text { Responsibility for compiling and } \\
\text { disseminating BOP is not directly stated } \\
\text { in the laws. Some working arrangements } \\
\text { with the NSI for conducting surveys } \\
\text { have not been effective. }\end{array}$ & $\begin{array}{l}\text { The BPD will consider the dissemination of } \\
\text { the CBB's Functions and Procedures } \\
\text { Manual to the public (medium-term). }\end{array}$ \\
\hline 0.2 Resources & & & 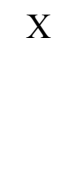 & & & $\begin{array}{l}\text { Insufficient staff for developmental } \\
\text { work in surveys. Staff have limited } \\
\text { access to telephones and Internet. }\end{array}$ & $\begin{array}{l}\text { The BPD will strengthen the unit responsible } \\
\text { for compiling balance of payment and } \\
\text { international investment position statistics } \\
\text { (medium-term). }\end{array}$ \\
\hline 0.3 Relevance & & & $\mathrm{X}$ & & & $\begin{array}{l}\text { Formal mechanisms for consulting } \\
\text { external users need to be strengthened. }\end{array}$ & \\
\hline 0.4 Other quality management & & & & & & & \\
\hline \multicolumn{8}{|l|}{ 1. Assurances of integrity } \\
\hline \multirow{3}{*}{$\begin{array}{ll}\text { 1.1 } & \text { Professionalism } \\
1.2 & \text { Transparency } \\
1.3 & \text { Ethical standards }\end{array}$} & & $\mathrm{X}$ & & & & & \\
\hline & & $\mathrm{X}$ & & & & & \\
\hline & & $\mathrm{X}$ & & & & & \\
\hline \multicolumn{8}{|l|}{ 2. Methodological soundness } \\
\hline 2.1 Concepts and definitions & & $\mathrm{X}$ & & & & & $\begin{array}{l}\text { The BPD will work towards assessing the } \\
\text { implications of the BPM5 update (medium- } \\
\text { term). }\end{array}$ \\
\hline 2.2 Scope & & & $\mathrm{X}$ & & & $\begin{array}{l}\text { Data exclude (1) unrecorded trade } \\
\text { (shuttle, contraband, and illegal trade), } \\
\text { (2) some government bonds issued } \\
\text { locally and held by nonresidents, and } \\
\text { (3) deposits made by nonresidents. }\end{array}$ & $\begin{array}{l}\text { The BPD will continue work toward } \\
\text { enhancing data coverage of private sector } \\
\text { transactions and positions, including services, } \\
\text { transfers, and remittances (short-term). }\end{array}$ \\
\hline 2.3 Classification/sectorization & & & $\mathrm{X}$ & & & $\begin{array}{l}\text { More detailed breakdown is needed for } \\
\text { the classification of several services. } \\
\text { Misclassifications in (1) institutional } \\
\text { sectors, (2) debt instruments, and } \\
\text { (3) transactions (current transfers } \\
\text { include capital transfers). }\end{array}$ & \\
\hline 2.4 Basis for recording & & & $\mathrm{X}$ & & & $\begin{array}{l}\text { Public external debt recorded on a due- } \\
\text { for-payment basis rather than on an } \\
\text { accrual basis. Dividends recorded when } \\
\text { paid rather than when declared payable. }\end{array}$ & \\
\hline
\end{tabular}


Table 6. Bolivia: Data Quality Assessment Framework (July 2003): Summary of Results for Balance of Payments Statistics (Compiling Agency: Central Bank of Bolivia)

\begin{tabular}{|c|c|c|c|c|c|c|c|}
\hline \multirow{2}{*}{ Element } & \multirow{2}{*}{ NA } & \multicolumn{4}{|c|}{ Assessment } & \multirow{2}{*}{ Comments on Assessment } & \multirow{2}{*}{ Plans for Improvement } \\
\hline & & $\mathrm{O}$ & LO & LNO & $\mathrm{NO}$ & & \\
\hline \multicolumn{8}{|l|}{ 3. Accuracy and reliability } \\
\hline 3.1 Source data & & \multirow{3}{*}{$\mathrm{X}$} & $\mathrm{X}$ & & & $\begin{array}{l}\text { Data sources for certain categories of } \\
\text { services and financial transactions need } \\
\text { to be improved. Some survey data and } \\
\text { direct reporting forms are delayed. }\end{array}$ & \multirow{5}{*}{$\begin{array}{l}\text { The BPD will place more emphasis in } \\
\text { conducting surveys to enhance CBB's BOP } \\
\text { statistics, in some cases in coordination with } \\
\text { other government agencies (short-term). }\end{array}$} \\
\hline \multirow{2}{*}{$\begin{array}{l}\text { 3.2 Assessment of source data } \\
\text { 3.3 Statistical techniques }\end{array}$} & & & & & & & \\
\hline & & & $\mathrm{X}$ & & & $\begin{array}{l}\text { No estimates for unrecorded trade. Some } \\
\text { statistical techniques need to be } \\
\text { strengthened (e.g., remittances, services, } \\
\text { direct investment income). }\end{array}$ & \\
\hline $\begin{array}{l}\text { 3.4 Assessment and validation of inter- } \\
\text { mediate data and statistical outputs }\end{array}$ & & \multirow[t]{2}{*}{$\mathrm{X}$} & & & & cos & \\
\hline 3.5 Revision studies & & & $\mathrm{X}$ & & & $\begin{array}{l}\text { Analysis of revisions are carried out } \\
\text { routinely but adequate documentation on } \\
\text { revisions is not maintained. }\end{array}$ & \\
\hline \multicolumn{8}{|l|}{ 4. Serviceability } \\
\hline \multirow{2}{*}{$\begin{array}{l}\text { 4.1 Periodicity and timeliness } \\
4.2 \text { Consistency }\end{array}$} & & \multirow[t]{3}{*}{$\mathrm{X}$} & & & & & \\
\hline & & & $\mathrm{X}$ & & & $\begin{array}{l}\text { Large errors and omissions for some } \\
\text { years. Some historical data series need } \\
\text { adjustment. Consistency with national } \\
\text { accounts data needs improvement. }\end{array}$ & \\
\hline 4.3 Revision policy and practice & & & $\mathrm{X}$ & & & $\begin{array}{l}\text { Comments and explanations on revisions } \\
\text { are included in CBB publications but } \\
\text { revision analyses are not disseminated. }\end{array}$ & \\
\hline \multicolumn{8}{|l|}{ 5. Accessibility } \\
\hline 5.1 Data accessibility & & $\mathrm{X}$ & & & & & \\
\hline 5.2 Metadata accessibility & & $\mathrm{X}$ & & & & & \\
\hline 5.3 Assistance to users & & $\mathrm{X}$ & & & & & \\
\hline
\end{tabular}




\section{Appendix I. Summary of the General Data Dissemination System (GDDS)}

\section{Data coverage, periodicity, and timeliness}

Dissemination of reliable, comprehensive, and timely economic, financial, and sociodemographic data is essential to the transparency of macroeconomic performance and policy. The GDDS contains specific recommendations concerning coverage, periodicity, and timeliness for comprehensive frameworks as well as for data categories and indicators.

\section{Quality}

Data quality must have a high priority. Data users must be provided with information to assess quality and quality improvements. The GDDS recommends:

- dissemination of documentation on methodology and sources used in preparing statistics; and

- dissemination of component detail, reconciliations with related data, and statistical frameworks that support statistical crosschecks and provide assurance of reasonableness.

\section{Integrity}

To fulfill the purpose of providing the public with information, official statistics must have the confidence of their users. In turn, confidence in the statistics ultimately becomes a matter of confidence in the objectivity and professionalism of the agency producing the statistics. Transparency of practices and procedures is a key factor in creating this confidence. The GDDS, therefore, recommends:

- dissemination of the terms and conditions under which official statistics are produced, including those relating to the confidentiality of individually identifiable information;

- identification of internal government access to data before release;

- identification of ministerial commentary on the occasion of statistical releases; and

- provision of information about revision and advance notice of major changes in methodology. 


\section{Access to the public}

Dissemination of official statistics is an essential feature of statistics as a public good. Ready and equal access by the public are principal requirements. The GDDS recommends:

- dissemination of advance release calendars; and

- $\quad$ simultaneous release to all interested parties.

\section{Plans for improvement}

The GDDS recommends that plans for improvement be developed for all areas in which shortcomings exist and that these plans be disseminated.

The GDDS also recommends that any needs for assistance be identified in the metadata. This may also be helpful for donors and technical assistance providers to prioritize their activities.

For each participating member country, the GDDS metadata provide descriptions of the dimensions listed above, together with plans for improvement and needs for assistance. This information is posted on the DSBB; participating countries are encouraged to also post the metadata on their national websites.

Source: Guide to the GDDS, March 2002: http://dsbb.imf.org 


\section{Appendix II. Summary of the Special Data Dissemination Standard (SDDS)}

The SDDS prescribes the following practices under each of the identified dimensions:

Data dimension (coverage, periodicity, and timeliness)

the dissemination of 18 data categories, including component detail, covering the four main sectors (real, fiscal, financial, and external) of the economy, with prescribed periodicity and timeliness.

\section{Access dimension}

the dissemination of advance release calendars providing at least one-quarter advance notice of approximate release dates, and at least a one-week advance notice of the precise release dates; and

the simultaneous release of data to all users.

\section{Integrity dimension}

the dissemination of the terms and conditions under which official statistics are produced and disseminated;

the identification of internal government access to data before release;

the identification of ministerial commentary on the occasion of statistical release; and

the provision of information about revision and advance notice of major changes in methodology.

\section{Quality dimension}

- the dissemination of documentation on statistical methodology and sources used in preparing statistics; and

- dissemination of component detail and/or additional data series that make possible cross-checks and checks of reasonableness.

SDDS subscribers are required to:

- post descriptions of their data dissemination practices (metadata) on the IMF's Dissemination Standards Bulletin Board (DSBB). Summary methodologies, which describe data compilation practices in some detail, are also disseminated on the DSBB; and 
- maintain an Internet website, referred to as the National Summary Data Page (NSDP), which contains the actual data described in the metadata and to which the DSBB is electronically linked.

The IMF staff is monitoring observance of the standard through NSDPs maintained on the Internet. Monitoring is limited to the coverage, periodicity, and timeliness of the data and to the dissemination of advance release calendars.

Source: http://dsbb.imf.org 
Table 7: Practices Compared to the SDDS Coverage, Periodicity, and Timeliness of Data

\begin{tabular}{|c|c|c|c|c|c|c|}
\hline \multirow{2}{*}{$\begin{array}{l}\text { SDDS } \\
\text { Data } \\
\text { Category }\end{array}$} & \multirow{2}{*}{$\begin{array}{l}\text { Coverage } \\
\text { meets } \\
\text { SDDS } \\
\text { requirement }\end{array}$} & \multicolumn{2}{|c|}{ Periodicity } & \multicolumn{2}{|c|}{ Timeliness } & \multirow{2}{*}{ Comments } \\
\hline & & SDDS & Bolivia & SDDS & Bolivia & \\
\hline \multicolumn{7}{|c|}{ DATA CATEGORIES AND INDICATORS } \\
\hline \multicolumn{7}{|l|}{ Real Sector } \\
\hline National accounts & Yes & Q & Q & $\mathrm{Q}$ & Q & Meets SDDS requirements \\
\hline $\begin{array}{l}\text { Production } \\
\text { index/indices }\end{array}$ & Yes & $\mathrm{M}$ & $\mathrm{M}$ & $\begin{array}{l}6 \mathrm{~W} \\
(1 M)\end{array}$ & $6 \mathrm{~W}$ & $\begin{array}{l}\text { Meets SDDS requirements. } \\
\text { Index on construction, mines, } \\
\text { telecommunications, } \\
\text { electricity, and other activities. }\end{array}$ \\
\hline $\begin{array}{l}\text { Forward-looking } \\
\text { Indicators }\end{array}$ & $\mathrm{N} / \mathrm{A}$ & $\mathrm{M}$ or $\mathrm{Q}$ & N/A & $\mathrm{M}$ or $\mathrm{Q}$ & N/A & Not compiled. \\
\hline Employment & Yes & $\mathrm{Q}$ & $\begin{array}{c}\mathrm{Q} \text { (public) } \\
2 \mathrm{Q} \text { (private) }\end{array}$ & $\mathrm{Q}$ & $\begin{array}{c}\mathrm{Q} \text { (public) } \\
4 \mathrm{M} \text { (private) }\end{array}$ & $\begin{array}{l}\text { SDDS requirements not met. } \\
\text { Labor market indicators for } \\
\text { the private sector are available } \\
\text { on a semiannual basis, based } \\
\text { on the Integrated Household } \\
\text { Survey (IHS). A quarterly } \\
\text { urban employment survey will } \\
\text { be conducted beginning } \\
\text { September } 2007 \text {. }\end{array}$ \\
\hline Unemployment & Yes & $\mathrm{Q}$ & $\mathrm{A}$ & $\mathrm{Q}$ & $4 \mathrm{M}$ & $\begin{array}{l}\text { SDDS requirements not met. } \\
\text { Data based on the (IHS). }\end{array}$ \\
\hline Wages/earnings & Yes & $\mathrm{Q}$ & $\begin{array}{c}\mathrm{Q}(\text { public }) \\
2 \mathrm{Q}(\text { private })\end{array}$ & Q & $\begin{array}{c}\mathrm{Q} \text { (public) } \\
4 \mathrm{M} \text { (private) }\end{array}$ & $\begin{array}{l}\text { SDDS requirements not met. } \\
\text { Two different surveys are } \\
\text { conducted, one for the public } \\
\text { and another one for private } \\
\text { sector. The survey for the } \\
\text { private sector is conducted } \\
\text { every six months, but there are } \\
\text { plans to conduct it on a } \\
\text { quarterly basis. }\end{array}$ \\
\hline $\begin{array}{l}\text { Consumer price } \\
\text { index }\end{array}$ & Yes & $\mathrm{M}$ & $\mathrm{M}$ & $\mathrm{M}$ & $\begin{array}{l}\text { One day after } \\
\text { the end of the } \\
\text { reference } \\
\text { month }\end{array}$ & Meets SDDS requirements. \\
\hline $\begin{array}{l}\text { Producer price } \\
\text { index }\end{array}$ & Yes & $\mathrm{M}$ & Q & $\mathrm{M}$ & $10 \mathrm{~W}$ & SDDS requirements not met. \\
\hline \multicolumn{7}{|l|}{ Fiscal Sector } \\
\hline $\begin{array}{l}\text { General } \\
\text { government } \\
\text { operations }\end{array}$ & Yes & A & $\mathrm{M}$ & $2 \mathrm{Q}$ & $6 \mathrm{~W}$ & Meets SDDS requirements. \\
\hline $\begin{array}{l}\text { Central government } \\
\text { operations }\end{array}$ & No & $\mathrm{M}$ & $\mathrm{M}$ & $\mathrm{M}$ & $6 \mathrm{~W}$ & $\begin{array}{l}\text { Meets SDDS requirements } \\
\text { for timeliness and } \\
\text { periodicity but not for } \\
\text { coverage. } \\
\text { Accounts for the central } \\
\text { government are not } \\
\text { consolidated. }\end{array}$ \\
\hline
\end{tabular}




\begin{tabular}{|c|c|c|c|c|c|c|}
\hline \multirow{2}{*}{$\begin{array}{c}\text { SDDS } \\
\text { Data } \\
\text { Category }\end{array}$} & \multirow{2}{*}{$\begin{array}{l}\text { Coverage } \\
\text { meets } \\
\text { SDDS } \\
\text { requirement }\end{array}$} & \multicolumn{2}{|c|}{ Periodicity } & \multicolumn{2}{|c|}{ Timeliness } & \multirow{2}{*}{ Comments } \\
\hline & & SDDS & Bolivia & SDDS & Bolivia & \\
\hline $\begin{array}{l}\text { Central government } \\
\text { debt }\end{array}$ & Yes & Q & $\begin{array}{c}\mathrm{W} \\
\text { (domestic) } \\
\mathrm{M} \text { (foreign) }\end{array}$ & Q & $\begin{array}{l}\text { 2D (domestic) } \\
\text { M (foreign) }\end{array}$ & Meets SDDS requirements. \\
\hline \multicolumn{7}{|l|}{ Financial Sector } \\
\hline $\begin{array}{l}\text { Analytical accounts } \\
\text { of the banking } \\
\text { sector }\end{array}$ & Yes & $\mathrm{M}$ & $\mathrm{M}$ & $\mathrm{M}$ & $3 \mathrm{~W}$ & Meets SDDS requirements. \\
\hline $\begin{array}{l}\text { Analytical accounts } \\
\text { of the central bank }\end{array}$ & Yes & $\begin{array}{c}\mathrm{M} \\
(1 W)\end{array}$ & $\mathrm{D}$ & $\begin{array}{l}2 \mathrm{~W} \\
(1 \mathrm{~W})\end{array}$ & $1 \mathrm{~W}$ & Meets SDDS requirements. \\
\hline Interest rates & Yes & $\mathrm{D}$ & $\mathrm{D}$ & 35 & $1 \mathrm{~W}$ & Meets SDDS requirements. \\
\hline $\begin{array}{l}\text { Stock market: share } \\
\text { price index }\end{array}$ & $\mathrm{N} / \mathrm{R}$ & $\mathrm{D}$ & $\mathrm{N} / \mathrm{R}$ & 27 & $\mathrm{~N} / \mathrm{R}$ & $\begin{array}{l}\text { Meets SDDS requirements. } \\
\text { Volume of transactions in the } \\
\text { stock exchange is negligible } \\
\text { and mostly in securities other } \\
\text { than shares. }\end{array}$ \\
\hline \multicolumn{7}{|l|}{ External Sector } \\
\hline $\begin{array}{l}\text { Balance of } \\
\text { payments }\end{array}$ & Yes & Q & Q & Q & $7 \mathrm{~W}$ & Meets SDDS requirements. \\
\hline $\begin{array}{l}\text { Official reserve } \\
\text { assets }\end{array}$ & Yes & $\begin{array}{l}\mathrm{M} \\
(W)\end{array}$ & $\mathrm{M}$ & $\mathrm{W}$ & $1 \mathrm{~W}$ & Meets SDDS requirements. \\
\hline Reserves template & Yes & $\mathrm{M}$ & $\mathrm{M}$ & $\mathrm{M}$ & $1 \mathrm{M}$ & Meets SDDS requirements. \\
\hline Merchandise trade & Yes & $\mathrm{M}$ & $\mathrm{M}$ & $\begin{array}{c}8 \mathrm{~W} \\
(4-6 \mathrm{~W})\end{array}$ & $4 \mathrm{~W}$ & Meets SDDS requirements. \\
\hline $\begin{array}{l}\text { International } \\
\text { investment } \\
\text { position }\end{array}$ & Yes & $\begin{array}{l}\mathrm{A} \\
(Q)\end{array}$ & Q & $\begin{array}{c}\mathrm{Q} \\
(1 Q)\end{array}$ & $7 \mathrm{~W}$ & Meets SDDS requirements. \\
\hline External debt & Yes & Q & $\begin{array}{l}\mathrm{M} \text { (public) } \\
\mathrm{Q} \text { (private) }\end{array}$ & Q & $\begin{array}{l}\mathrm{M} \text { (public) } \\
\mathrm{Q} \text { (private) }\end{array}$ & Meets SDDS requirements. \\
\hline Exchange rates & Yes & $\mathrm{D}$ & $\mathrm{D}$ & 1 & Same day & Meets SDDS requirements. \\
\hline $\begin{array}{l}\text { Addendum: } \\
\text { Population }\end{array}$ & & $\mathrm{A}$ & $\mathrm{A}$ & $\ldots$ & $1 \mathrm{M}$ & Meets SDDS requirements. \\
\hline
\end{tabular}

Note: Periodicity and timeliness: (D) daily; (W) weekly or with a lag of no more than one week from the reference data or the closing of the reference week; (M) monthly or with a lag of no more than one month; (Q) quarterly or with a lag of no more than one quarter; (A) annually; (N/A) not available; and (N/R) not relevant.

Advanced Released Calendars (ARC) are disseminated at: http://www.bcb.gov.bo/sitio/estadisticast.php?n2=5\&n3=9\&n4=. As of February 8, the latest ARC referred to 2006.

Italics indicate encouraged categories/practices.

${ }^{35}$ Given that data are widely available from private sources, dissemination of official producers may be less time-sensitive. Although dissemination by recorded telephone messages or fax services is encouraged, dissemination of these data can be made part of other (preferably high-frequency) dissemination products. 


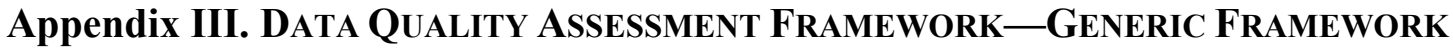 (JULY 2003 FRAMEWORK)}

\begin{tabular}{|c|c|c|}
\hline Quality Dimensions & Elements & Indicators \\
\hline \multirow[t]{4}{*}{$\begin{array}{l}\text { 0. Prerequisites of } \\
\text { quality }\end{array}$} & $\begin{array}{l}\text { 0.1 Legal and institutional } \\
\text { environment-The environment } \\
\text { is supportive of statistics }\end{array}$ & $\begin{array}{l}\text { 0.1.1 The responsibility for collecting, processing, } \\
\text { and disseminating the statistics is clearly specified. } \\
\text { 0.1.2 Data sharing and coordination among data- } \\
\text { producing agencies are adequate. } \\
\text { 0.1.3 Individual reporters' data are to be kept } \\
\text { confidential and used for statistical purposes only. } \\
\text { 0.1.4 Statistical reporting is ensured through legal } \\
\text { mandate and/or measures to encourage response. }\end{array}$ \\
\hline & $\begin{array}{l}\mathbf{0 . 2} \text { Resources-Resources are } \\
\text { commensurate with needs of } \\
\text { statistical programs. }\end{array}$ & $\begin{array}{l}\text { 0.2.1 Staff, facilities, computing resources, and } \\
\text { financing are commensurate with statistical } \\
\text { programs. } \\
0.2 .2 \text { Measures to ensure efficient use of resources } \\
\text { are implemented. }\end{array}$ \\
\hline & $\begin{array}{l}\mathbf{0 . 3} \text { Relevance }- \text { Statistics cover } \\
\text { relevant information on the } \\
\text { subject field. }\end{array}$ & $\begin{array}{l}\text { 0.3.1 The relevance and practical utility of existing } \\
\text { statistics in meeting users' needs are monitored. }\end{array}$ \\
\hline & $\begin{array}{l}\text { 0.4 Other quality } \\
\text { management-Quality is a } \\
\text { cornerstone of statistical work. }\end{array}$ & $\begin{array}{l}\text { 0.4.1 Processes are in place to focus on quality. } \\
0.4 .2 \text { Processes are in place to monitor the quality of } \\
\text { the statistical program. } \\
\text { 0.4.3 Processes are in place to deal with quality } \\
\text { considerations in planning the statistical program. }\end{array}$ \\
\hline \multirow{3}{*}{$\begin{array}{l}\text { 1. Assurances of } \\
\text { integrity } \\
\text { The principle of } \\
\text { objectivity in the } \\
\text { collection, } \\
\text { processing, and } \\
\text { dissemination of } \\
\text { statistics is firmly } \\
\text { adhered to. }\end{array}$} & $\begin{array}{l}\text { 1.1 Professionalism—Statistical } \\
\text { policies and practices are } \\
\text { guided by professional } \\
\text { principles. }\end{array}$ & $\begin{array}{l}\text { 1.1.1 Statistics are produced on an impartial basis. } \\
\text { 1.1.2 Choices of sources and statistical techniques } \\
\text { as well as decisions about dissemination are } \\
\text { informed solely by statistical considerations. } \\
\text { 1.1.3 The appropriate statistical entity is entitled to } \\
\text { comment on erroneous interpretation and misuse of } \\
\text { statistics. }\end{array}$ \\
\hline & $\begin{array}{l}\text { 1.2 Transparency_-Statistical } \\
\text { policies and practices are } \\
\text { transparent. }\end{array}$ & $\begin{array}{l}\text { 1.2.1 The terms and conditions under which } \\
\text { statistics are collected, processed, and disseminated } \\
\text { are available to the public. } \\
\text { 1.2.2 Internal governmental access to statistics prior } \\
\text { to their release is publicly identified. } \\
\text { 1.2.3 Products of statistical agencies/units are } \\
\text { clearly identified as such. } \\
\text { 1.2.4 Advance notice is given of major changes in } \\
\text { methodology, source data, and statistical techniques. }\end{array}$ \\
\hline & $\begin{array}{l}1.3 \text { Ethical standards-Policies } \\
\text { and practices are guided by } \\
\text { ethical standards. }\end{array}$ & $\begin{array}{l}\text { 1.3.1 Guidelines for staff behavior are in place and } \\
\text { are well known to the staff. }\end{array}$ \\
\hline
\end{tabular}




\begin{tabular}{|c|c|c|}
\hline Quality Dimensions & Elements & Indicators \\
\hline $\begin{array}{l}\text { 2. Methodological } \\
\text { soundness } \\
\text { The methodological } \\
\text { basis for the } \\
\text { statistics follows } \\
\text { internationally } \\
\text { accepted standards, } \\
\text { guidelines, or good } \\
\text { practices. }\end{array}$ & $\begin{array}{l}\text { 2.1 Concepts and definitions-- } \\
\text { Concepts and definitions used } \\
\text { are in accord with } \\
\text { internationally accepted } \\
\text { statistical frameworks. } \\
\mathbf{2 . 2} \text { Scope-The scope is in } \\
\text { accord with internationally } \\
\text { accepted standards, guidelines, } \\
\text { or good practices. } \\
\mathbf{2 . 3} \text { Classification/ } \\
\text { sectorization-Classification } \\
\text { and sectorization systems are in } \\
\text { accord with internationally } \\
\text { accepted standards, guidelines, } \\
\text { or good practices. } \\
\mathbf{2 . 4} \text { Basis for recording-Flows } \\
\text { and stocks are valued and } \\
\text { recorded according to } \\
\text { internationally accepted } \\
\text { standards, guidelines, or good } \\
\text { practices }\end{array}$ & $\begin{array}{l}\text { 2.2.1 The scope is broadly consistent with } \\
\text { internationally accepted standards, guidelines, or } \\
\text { good practices. } \\
\text { 2.3.1 Classification/sectorization systems used are } \\
\text { broadly consistent with internationally accepted } \\
\text { standards, guidelines, or good practices. }\end{array}$ \\
\hline $\begin{array}{l}\text { 3. Accuracy and } \\
\text { reliability } \\
\text { Source data and } \\
\text { statistical techniques } \\
\text { are sound and } \\
\text { statistical outputs } \\
\text { sufficiently portray } \\
\text { reality }\end{array}$ & $\begin{array}{l}\text { 3.3 Statistical techniques-- } \\
\text { Statistical techniques employed } \\
\text { conform to sound statistical } \\
\text { procedures } \\
\text { 3.4 Assessment and validation } \\
\text { of intermediate data and } \\
\text { statistical outputs- } \\
\text { Intermediate results and } \\
\text { statistical outputs are regularly } \\
\text { assessed and validated. } \\
\text { 3.5 Revision studies- } \\
\text { Revisions, as a gauge of } \\
\text { reliability, are tracked and } \\
\text { mined for the information they } \\
\text { may provide. }\end{array}$ & $\begin{array}{l}\text { 3.1.1 Source data are obtained from comprehensive } \\
\text { data collection programs that take into account } \\
\text { country-specific conditions. } \\
\text { 3.1.2 Source data reasonably approximate the } \\
\text { definitions, scope, classifications, valuation, and } \\
\text { time of recording required. } \\
\text { 3.1.3 Source data are timely. } \\
\text { 3.2.1 Source data-including censuses, sample } \\
\text { surveys, and administrative records-are routinely } \\
\text { assessed, e.g., for coverage, sample error, response } \\
\text { error, and nonsampling error; the results of the } \\
\text { assessments are monitored and made available to } \\
\text { guide statistical processes. } \\
\text { 3.3.1 Data compilation employs sound statistical } \\
\text { techniques to deal with data sources. } \\
\text { 3.3.2 Other statistical procedures (e.g., data } \\
\text { adjustments and transformations, and statistical } \\
\text { analysis) employ sound statistical techniques. } \\
\text { 3.4.1 Intermediate results are validated against other } \\
\text { information where applicable. } \\
\text { 3.4.2 Statistical discrepancies in intermediate data } \\
\text { are assessed and investigated. } \\
\text { 3.4.3 Statistical discrepancies and other potential } \\
\text { indicators or problems in statistical outputs are } \\
\text { investigated. } \\
\text { 3.5.1 Studies and analyses of revisions are carried } \\
\text { out routinely and used internally to inform statistical } \\
\text { processes (see also 4.3.3). }\end{array}$ \\
\hline
\end{tabular}




\begin{tabular}{|c|c|c|}
\hline Quality Dimensions & Elements & Indicators \\
\hline $\begin{array}{l}\text { 4. Serviceability } \\
\text { Statistics, with } \\
\text { adequate periodicity } \\
\text { and timeliness, are } \\
\text { consistent and } \\
\text { follow a predictable } \\
\text { revisions policy. }\end{array}$ & $\begin{array}{l}\text { 4.1 Periodicity and } \\
\text { timeliness-Periodicity and } \\
\text { timeliness follow internationally } \\
\text { accepted dissemination } \\
\text { standards. } \\
4.2 \text { Consistency_-Statistics are } \\
\text { consistent within the dataset, } \\
\text { over time, and with major } \\
\text { datasets. } \\
\text { 4.3 Revision policy and } \\
\text { practice-Data revisions follow } \\
\text { a regular and publicized } \\
\text { procedure. }\end{array}$ & $\begin{array}{l}\text { 4.2.1 Statistics are consistent within the dataset. } \\
\text { 4.2.2 Statistics are consistent or reconcilable over a } \\
\text { reasonable period of time. } \\
\text { 4.2.3 Statistics are consistent or reconcilable with } \\
\text { those obtained through other data sources and/or } \\
\text { statistical frameworks. } \\
\text { 4.3.1 Revisions follow a regular and transparent } \\
\text { schedule. } \\
\text { 4.3.2 Preliminary and/or revised data are clearly } \\
\text { identified. } \\
\text { 4.3.3 Studies and analyses of revisions are made } \\
\text { public (see also 3.5.1). }\end{array}$ \\
\hline $\begin{array}{l}\text { 5. Accessibility } \\
\text { Data and metadata } \\
\text { are easily available } \\
\text { and assistance to } \\
\text { users is adequate. }\end{array}$ & $\begin{array}{l}\text { 5.1 Data accessibility- } \\
\text { Statistics are presented in a } \\
\text { clear and understandable } \\
\text { manner, forms of dissemination } \\
\text { are adequate, and statistics are } \\
\text { made available on an impartial } \\
\text { basis. } \\
\\
\text { 5.2 Metadata accessibility- } \\
\text { Up-to-date and pertinent } \\
\text { metadata are made available. }\end{array}$ & $\begin{array}{l}\text { 5.1.1 Statistics are presented in a way that facilitates } \\
\text { proper interpretation and meaningful comparisons } \\
\text { (layout and clarity of text, tables, and charts). } \\
\text { 5.1.2 Dissemination media and format are adequate. } \\
\text { 5.1.3 Statistics are released on a preannounced } \\
\text { schedule. } \\
\text { 5.1.4 Statistics are made available to all users at the } \\
\text { same time. } \\
\text { 5.1.5 Statistics not routinely disseminated are made } \\
\text { available upon request. } \\
\text { 5.2.1 Documentation on concepts, scope, } \\
\text { classifications, basis of recording, data sources, and } \\
\text { statistical techniques is available, and differences } \\
\text { from internationally accepted standards, guidelines, } \\
\text { or good practices are annotated. } \\
\text { 5.2.2 Levels of detail are adapted to the needs of the } \\
\text { intended audience. } \\
\text { 5.3.1 Contact points for each subject field are } \\
\text { publicized. } \\
\text { 5.3.2 Catalogs of publications, documents, and other } \\
\text { services, including information on any charges, are } \\
\text { widely available. }\end{array}$ \\
\hline
\end{tabular}




\section{Appendix IV. Users' Survey}

As a complement to the IMF's assessment of the quality of official statistics produced by Bolivia, with assistance from the authorities, the mission conducted an informal survey of key users of macroeconomic statistics. Questionnaires were sent to a broad range of users, including academics, banks, nonbank financial institutions, government agencies, business associations, international organizations, and the media.

Users were asked to evaluate the coverage, periodicity, timeliness, dissemination practices, accessibility, and overall quality of the official statistics produced by the Central Bank of Bolivia, the Ministry of Finance, and the National Statistics Institute. Surveys were sent to 329 targeted users, with 85 of them submitting responses resulting in a 26 percent response rate.

The respondents indicated that the official statistics they used the most were the monetary statistics, followed by the consumer price index and national accounts. Respondents also indicated that their main use of official statistics was for short-term decisions based on current economic developments, with the vast majority relying on official press releases and publications as their primary source.

On a five point scale $(1=$ poor and $5=$ excellent $)$, the average rating for the overall quality of the official statistics for all sectors was 3.5. There was variation among the averages for each of the main datasets, with up to 0.9 difference between the sector that scored the highest (monetary) and the one that scored the lowest (government finance statistics). Sixty-six percent of all respondents across sectors felt that Bolivia's statistics were of comparable quality to those disseminated by neighboring countries, with a sizable 28 percent rating the quality as worse.

There was broad satisfaction with the methodological soundness of Bolivia's official statistics, with 81 percent of respondents feeling that the statistics were reliable. However, a smaller number of respondents (62 percent) felt that official statistics are unbiased and accurate. In this regard, variability across the sectors was significant with the highest rating for accuracy and reliability going to monetary statistics (75 percent of respondents) and the lowest rating given to government finance statistics ( 52 percent of respondents).

More than three-quarters of respondents were satisfied with the level of coverage and detail of official statistics. In the written comments, however, many respondents requested greater detail of the statistics, particularly with regard to national accounts and government finance statistics.

The level of satisfaction of respondents with periodicity and timeliness was mixed. A considerable 76 percent of respondents were satisfied with the periodicity of official statistics. In contrast, respondents expressed general dissatisfaction with the timeliness of statistics, with only 54 percent expressing satisfaction. Among the datasets, national accounts had the lowest satisfaction rating by users regarding timeliness (38 percent) while monetary statistics scored the highest (69 percent). 
Overall accessibility to official statistics was satisfactory with a 78 percent positive response rate. However, respondents expressed general dissatisfaction with the accessibility to metadata, with only 40 percent of them being satisfied. In addition, only 30 percent felt that the available metadata was sufficiently clear or detailed enough to be useful. In most cases, official websites were the most popular means of accessing Bolivia's statistics, with 76 percent of the respondents relying on this method. The next popular means was hard copy publications.

With respect to dissemination practices, as much as 85 percent of respondents indicated that they were unaware of the existence of any official advance release calendar. A significant 67 percent of respondents also felt that the official data releases did not follow the preannounced calendar. In terms of revisions of previously published data, 55 percent of users felt that sufficient information was provided.

Many respondents took advantage of the survey and provided additional comments and suggestions concerning Bolivia's statistics. Among several of these, which are summarized below, users expressed interest in receiving greater regional breakdown of statistics, particularly with regards to national accounts, more detailed government finance statistics, improved periodicity and timeliness for most datasets, and new data series such as the producer price index and forward looking indicators. These comments are shown below, grouped into five categories: (1) prerequisites of quality, (2) methodological soundness, (3) accuracy and reliability, (4) serviceability, (5) accessibility, and (6) general comments. 
Table 8: Questionnaire Results Analyzed by Type of User

January 2007

\begin{tabular}{|l|r|r|r|}
\hline \multicolumn{1}{|c|}{ Respondent } & Sent & Received & $\begin{array}{c}\text { Response } \\
\text { Rate Per } \\
\text { Group }\end{array}$ \\
\hline Banks & 39 & 12 & $31 \%$ \\
Business associations & 33 & 11 & $33 \%$ \\
International Organizations & 10 & 3 & $30 \%$ \\
Media & 25 & 1 & $4 \%$ \\
Nonbank financial corporations & 48 & 12 & $25 \%$ \\
Private nonfinancial corporations & 17 & 3 & $18 \%$ \\
Public sector analysts & 97 & 36 & $37 \%$ \\
Universities & 60 & 7 & $12 \%$ \\
\hline Total & 329 & 85 & $26 \%$ \\
\hline
\end{tabular}


Table 9. Results of Users' Survey

(In percentage of total responses)

January 2007

\section{General Information About Uses of Official Macroeconomic Statistics of Bolivia}

1. Which official statistics do you use regularly?

\begin{tabular}{|l|r|}
\hline a. National accounts (NA) & $65 \%$ \\
b. Prices & $73 \%$ \\
c. Government finance statistics (GFS) & $62 \%$ \\
d. Monetary statistics (Monetary) & $81 \%$ \\
e. Balance of payments (BOP) & $54 \%$ \\
f. Other: & \\
$\cdot \quad$ Production indices & $36 \%$ \\
$\quad$ Labor market & $33 \%$ \\
Merchandise trade & $28 \%$ \\
$\cdot \quad$ International reserves and foreign currency liquidity & $43 \%$ \\
$\cdot \quad$ External debt & $49 \%$ \\
$\quad$ International investment position & $35 \%$ \\
Other & $12 \%$ \\
\hline
\end{tabular}

2. Where do you obtain the official statistics?

\begin{tabular}{|l|c|}
\hline a. Official press releases and publications on macroeconomic statistics & $81 \%$ \\
b. Private sector summaries and analyses & $54 \%$ \\
c. Official policy papers & $47 \%$ \\
d. Publications from international organizations about the country & $56 \%$ \\
e. Other sources & $25 \%$ \\
\hline
\end{tabular}

3. Do you refer to official descriptions of the sources and methods that were used to compile the official statistics?

\begin{tabular}{|c|c|}
\hline Yes & $67 \%$ \\
\hline No & $33 \%$ \\
\hline
\end{tabular}

\section{For what purposes do you use the official statistics?}

\begin{tabular}{|l|c|}
\hline a. Analysis of current developments for short-term decision making & $77 \%$ \\
b. Analysis of trends for longer-term policy formulation? & $73 \%$ \\
c. Econometric model building and forecasting & $32 \%$ \\
d. Economic research & $63 \%$ \\
e. Comparison with economic developments in other countries & $42 \%$ \\
f. General economic background & $53 \%$ \\
g. Other & $17 \%$ \\
\hline
\end{tabular}


Table 9. Bolivia: Results of Users' Survey

(In percentage of total responses)

January 2007

NA Prices GFS MS BOP Other

Average $^{36}$

\section{Coverage and detail}

5.1 In general, are you satisfied with the coverage of official statistics?

$\cdot$ Yes

- No

\begin{tabular}{l|l|l|}
\hline $85 \%$ & $84 \%$ & $72 \%$ \\
$15 \%$ & $16 \%$ & $28 \%$ \\
\hline
\end{tabular}

$28 \% \quad 5 \%$

$5 \%$

\begin{tabular}{l|l|}
\hline $10 \%$ & $44 \%$ \\
\hline
\end{tabular}

$85 \%$

$15 \%$

5.2 In general, are you satisfied with the official statistics in terms of their level of detail?

\begin{tabular}{|l|l|l|l|l|l|l|}
$\cdot$ Yes & $79 \%$ & $82 \%$ & $64 \%$ & $88 \%$ & $85 \%$ & $63 \%$ \\
$\cdot$ No & $21 \%$ & $18 \%$ & $36 \%$ & $12 \%$ & $15 \%$ & $38 \%$ \\
\hline
\end{tabular}

\section{Periodicity and timeliness}

6.1 Are you satisfied with the frequency of compilation of the official statistics (e.g., weekly, monthly, quarterly, annual)?

\begin{tabular}{|l|l|l|l|l|l|l|}
$\cdot$ Yes & $70 \%$ & $80 \%$ & $73 \%$ & $84 \%$ & $74 \%$ & $38 \%$ \\
$\cdot$ No & $30 \%$ & $20 \%$ & $27 \%$ & $16 \%$ & $26 \%$ & $63 \%$ \\
\hline
\end{tabular}

6.2. In general, do you consider that the official statistics are disseminated with the appropriate timeliness (the time lag after the period to which they pertain, e.g., 60 days after the reference period)?

\begin{tabular}{l|llllll}
$\cdot$ Yes & $38 \%$ & $67 \%$ & $50 \%$ & $69 \%$ & $44 \%$ & $29 \%$ \\
$\cdot$ No & $62 \%$ & $33 \%$ & $50 \%$ & $31 \%$ & $56 \%$ & $71 \%$ \\
\hline
\end{tabular}

\section{Other dissemination practices}

7.1 Do you know if there is a publicly disseminated calendar that announces in advance the dates on which the various official statistics will be disseminated?

\begin{tabular}{l|l|l|l|l|l|c|}
$\cdot$ Yes & $13 \%$ & $18 \%$ & $12 \%$ & $18 \%$ & $12 \%$ & $0 \%$ \\
$\cdot$ No & $87 \%$ & $82 \%$ & $88 \%$ & $82 \%$ & $88 \%$ & $100 \%$ \\
\hline
\end{tabular}

7.2 If there is a calendar of release dates, in your experience, are the official statistics released on the dates announced?

\begin{tabular}{|c|c|c|c|c|c|c|c|}
\hline $\begin{array}{l}\cdot \text { Yes } \\
\cdot \text { No } \\
\end{array}$ & $\begin{array}{l}27 \% \\
73 \% \\
\end{array}$ & $\begin{array}{l}38 \% \\
63 \% \\
\end{array}$ & $\begin{array}{l}28 \% \\
72 \% \\
\end{array}$ & $\begin{array}{l}40 \% \\
60 \% \\
\end{array}$ & $\begin{array}{l}32 \% \\
68 \% \\
\end{array}$ & $\begin{array}{l}25 \% \\
75 \% \\
\end{array}$ & $\begin{array}{l}33 \% \\
67 \% \\
\end{array}$ \\
\hline \multicolumn{7}{|c|}{ 7.3 Is there enough information about revisions to official statistics? } & \\
\hline $\begin{array}{l}\cdot \text { Yes } \\
\cdot \text { No }\end{array}$ & $\begin{array}{l}49 \% \\
51 \%\end{array}$ & $\begin{array}{l}53 \% \\
47 \%\end{array}$ & $\begin{array}{l}46 \% \\
54 \%\end{array}$ & $\begin{array}{l}63 \% \\
37 \%\end{array}$ & $\begin{array}{l}64 \% \\
36 \%\end{array}$ & $\begin{array}{l}50 \% \\
50 \%\end{array}$ & $\begin{array}{l}55 \% \\
45 \%\end{array}$ \\
\hline
\end{tabular}

${ }^{36}$ Averages exclude responses to other statistics. 


\section{Table 9. Bolivia: Results of Users' Survey (In percentage of total responses) January 2007}

\begin{tabular}{|l|l|l|l|l|l|}
\hline NA & Prices & GFS & MS & BOP & Other Average $^{1}$ \\
\hline
\end{tabular}

\section{Accessibility}

8.1 Can you easily access the official statistics?

\begin{tabular}{lcccccc}
$\cdot$ Yes & $73 \%$ & $76 \%$ & $65 \%$ & $91 \%$ & $84 \%$ & $60 \%$ \\
$\cdot$ No & $27 \%$ & $24 \%$ & $35 \%$ & $9 \%$ & $16 \%$ & $40 \%$ \\
\hline
\end{tabular}

\begin{tabular}{l|}
$78 \%$ \\
$22 \%$ \\
\hline
\end{tabular}

8.2 Can you easily access information pertaining to official statistics you use (explanatory notes, methodological descriptions, reference concerning concepts, classification, statistical practice)?

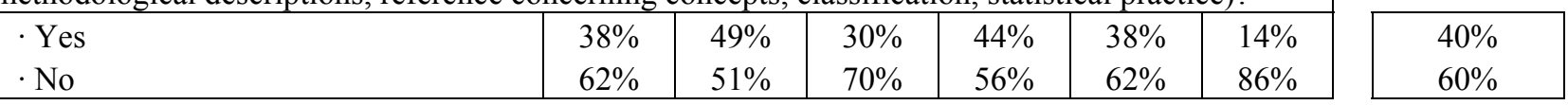

8.3 Is the above information on methodology sufficiently clear and at an adequate level of detail to be useful to you?

$$
\begin{aligned}
& \cdot \text { Yes } \\
& \cdot \text { No } \\
& \cdot \text { No Opinion }
\end{aligned}
$$

8.4 How do you get access to official statistics?

- Official releases

- Hard copy publications

- Data specifically requested

- Official website

- Other

- E-mail requests

\section{Overall assessment}

\begin{tabular}{|l|c|c|c|c|c|c|}
\hline 9.1 In your opinion, is the underlying methodology of official statistics sound and appropriate? \\
\hline$\cdot$ Yes & $75 \%$ & $81 \%$ & $75 \%$ & $89 \%$ & $83 \%$ & $100 \%$ \\
$\cdot$ No & $25 \%$ & $19 \%$ & $25 \%$ & $11 \%$ & $17 \%$ & $0 \%$ \\
\hline
\end{tabular}

\begin{tabular}{|l|c|c|c|c|c|c|}
\hline 9.2 In general, do you consider the official statistics to be unbiased and accurate? \\
\hline$\cdot$ Yes & $61 \%$ & $58 \%$ & $52 \%$ & $75 \%$ & $62 \%$ & $50 \%$ \\
$\cdot$ No & $39 \%$ & $42 \%$ & $48 \%$ & $25 \%$ & $38 \%$ & $50 \%$ \\
\hline
\end{tabular}

\begin{tabular}{|l|}
\hline $62 \%$ \\
$38 \%$ \\
\hline
\end{tabular}

9.3 How would you compare the quality of official statistics of the country with those of other countries in the region?

\begin{tabular}{l|c|c|c|c|c|c|}
$\cdot$ Better & $3 \%$ & $5 \%$ & $3 \%$ & $15 \%$ & $4 \%$ & $0 \%$ \\
$\cdot$ Same & $66 \%$ & $67 \%$ & $57 \%$ & $70 \%$ & $70 \%$ & $57 \%$ \\
$\cdot$ - Worse & $31 \%$ & $28 \%$ & $40 \%$ & $15 \%$ & $26 \%$ & $43 \%$ \\
\hline
\end{tabular}

$6 \%$

$66 \%$

$28 \%$

9.4 How do you assess the overall quality of the official statistics?

$(1$ rated $=$ poor; $5=$ excellent $)$

\begin{tabular}{l|l|l|}
\hline 3.3 & 3.5 & 3.1
\end{tabular}

4.0

\begin{tabular}{l|l|}
3.6 & 1.7 \\
\hline
\end{tabular}

NA = National Accounts; Prices refer to: CPI (Consumer Price Index) and PPI (Producer Price Index) $\mathrm{GFS}=$ Government Finance Statistics; MS = Monetary Statistics; and BOP = Balance of Payments Statistics 


\section{Appendix V. Bolivia: Comments by Users of Macroeconomic Statistics}

\section{Prerequisites of quality}

- Improvements in the quality of official statistics should be given greater priority by increasing resources for censuses and surveys, such as in the areas of employment, manufacturing, and investment. In addition, other surveys should be conducted that permit economic programming in the short, medium, and long-term horizon.

- Household surveys are not apparently included in the budget of the NSI and they depend on external financing for this activity. I hope that this policy is not viewed as correct since household surveys are major function of the NSI.

\section{Methodological soundness}

- The base year for national accounts and prices should be updated.

- Government finance statistics have been improving in terms of their coverage, timeliness, quality, and transparency thanks to the continued efforts of government agencies in charge of data compilation. Nonetheless, there still needs to be improvements in the statistics in order to meet international standards.

- In general, there have been some advances in the level of availability and accessibility of official statistics. However, there are other aspects that should be improved, such as the methodologies applied, the periodicity of the data, and its timeliness.

\section{Accuracy and reliability}

- It is necessary to improve the quality of the balance of payments and national accounts statistics.

- In the specific case of statistics on public investment, the information is deficient in terms is reliability, timeliness, and detail.

\section{Serviceability}

- The greatest concern is poor timeliness in which the official statistics are published. This often lessens the usefulness of the data.

- Data disseminated by the NSI suffer from poor timeliness, reducing its prestige as a statistical provider of excellence.

- The coverage and timeliness of national accounts statistics should be improved.

- Labor statistics should have greater periodicity (monthly or quarterly) and be timely. The labor statistics currently disseminated is clearly deficient.

- In terms of balance of payments statistics, its biggest deficiency is the absence of final historical data and significant inconsistencies in the data from the different government agencies. 
- The data provided by the Ministry of Finance could be improved in terms of presentation, clarity, timeliness, and level of detail. Presenting this improved data on their website would be a significant improvement.

- Existing discrepancies in the official statistics should be explained. There should be greater coordination among providers of statistics.

\section{Accessibility}

- Information on methodology should be clear and easily accessible. Public, private, and foreign investment data should be produced.

- The NSI should have a faster website. Downloads take too long even with broadband.

- Statistics on national accounts and government finance require better information on the methodology and notification of release dates.

- It is difficult to obtain methodological information on the CBB website.

- It takes longer to search for information on the CBB's website compared with other similar websites.

- Monetary and financial statistics should be disseminated on a daily basis, with greater detail.

- The internet should be used more often to disseminate data and metadata. The delivery of information could be more effective and personalized.

- There is not enough information on the type of data available and the means of access.

- Source data should be made available for users, when requested.

- Official statistics should be disseminated more widely, not only on the internet but also via other means such as the radio, magazines, etc.

\section{General comments}

- The new regional context of the country requires precise and timely statistics by region and, if possible, by municipality.

- Greater detail in national accounts statistics should be produced to facilitate sectoral analysis of the economy.

- It would be best to work with data that is more detailed, especially in the case of national accounts, government finance, and balance of payments.

- Forward leading indicator surveys should be developed, so that references of level of economic activity can be obtained.

- The provision of producer price indices or wholesale price indices would be of great use.

- In general, there is ease of access to official statistics; however, the level of detail is not sufficient in many datasets. For example, some data are only available on an annual basis when monthly evolution of the data is necessary.

- The monetary and financial statistics are of excellent quality thanks to the efforts of the CBB and SBFE.

- The merchandise trade data requires greater detail in terms of region, product, and country.

- Statistics on household income by region is needed.

- Official statistics should be more in line with international standards in order to enhance comparability. 